\title{
Aspects of the Chronology, Structure and Thermal History of the Kawerau Geothermal Field
}

\author{
By \\ Sarah Dawn Milicich \\ A thesis \\ submitted to Victoria University of Wellington \\ in fulfilment of the requirements for the degree of \\ Doctor of Philosophy in Geology \\ Victoria University of Wellington \\ School of Geography, Environment and Earth Sciences \\ Wellington, New Zealand
}


'It is what it is'

id est quod est

J.L. Wooden

(pers. comm. 2010) 


\begin{abstract}
The development and management of high-temperature geothermal resources for electrical power generation requires accurate knowledge of the local geological conditions, particularly where they impact on the hydrology of the resource. This study is an integrated programme of work designed to develop new perspectives on the geological and structural framework of the Kawerau geothermal resource as a sound basis for field management. Although the geological approaches and techniques utilised in this study have previously been used, their application to an integrated study of a geothermal system in New Zealand has not been previously undertaken.
\end{abstract}

Correlating volcanic and sedimentary stratigraphy in geothermal areas in New Zealand can be challenging due to similarities in lithology and the destruction of distinctive chemical, mineralogical and textural characteristic by hydrothermal alteration. A means to overcoming these issues is to utilise dating to correlate the stratigraphy. Zircons are resistant to the effects of typical hydrothermal conditions and were dated using SIMS techniques (SHRIMP-RG) to retrieve $\mathrm{U}-\mathrm{Pb}$ ages on zircons. These age data were then used to correlate units across the field, in part aided by correlations to material that had previously been dated from fresh rock by ${ }^{40} \mathrm{Ar} /{ }^{39} \mathrm{Ar}$ techniques, and used to redefine the stratigraphic framework for the area.

To aid correlation using $\mathrm{U}-\mathrm{Pb}$ ages and petrographic descriptions, a 3-D visualisation of the geology was built using Leapfrog Geothermal modelling software. The ability to model geology in a 3-D interface has provided new insights regarding the geological framework, controls on deep-seated permeability, volcanic and basement stratigraphic correlations, and geothermal system evolution in the Kawerau area. Some key insights into the stratigraphy in the area include:

- Numerous coherent bodies of rhyolite, previously described as individual eruptive units, have been shown to be a series of extrusive domes and their associated intrusive equivalents emplaced around $0.36 \pm 0.03 \mathrm{Ma}$ (domes and sills) and $0.138 \pm 0.007 \mathrm{Ma}$ (dikes and domes still exposed at surface).

- Below the regional marker plane of the $0.32 \mathrm{Ma}$ Matahina ignimbrite, three main groups of ignimbrites occur, with ages around $1.45 \mathrm{Ma}, 1.0 \mathrm{Ma}$ and $0.6-0.5 \mathrm{Ma}$, which are separated by sediment-dominated intervals (accumulated at average rates of 0.06 $\mathrm{mm} / \mathrm{yr}$ ) and one section of andesitic lavas. All of these ignimbrites represent marker horizons from other volcanic centres and do not reflect the presence of local magmatic heat sources. 
- The earliest dated ignimbrites yield age estimates of c. 2.4 and 2.1 Ma, consistent with these units being distal southern Coromandel Volcanic Zone deposits, pre-dating TVZ activity.

The correlation of regional stratigraphic markers allowed inferences into the structural development of the area.

- Prior to $1.5 \mathrm{Ma}$, faulting beneath Kawerau was dominantly on northwest-southeast strike-slip structures, with associated development of half grabens in which accumulated sediment-rich intervals (greywacke gravels, and fine sediments with interbedded tuffs). Post-1.5 Ma normal faulting has accompanied episodic subsidence of the Kawerau area, with fault movement along northeast-southwest structures (associated with the geometry of the modern TVZ) and the reactivated northwestsoutheast structures associated with most displacement in the area prior to $1.5 \mathrm{Ma}$.

- Net subsidence rates inferred from depths to key units do not reflect the present-day situation. Modern rates of tectonic subsidence $(2 \pm 1 \mathrm{~mm} / \mathrm{yr})$ associated with TVZ rifting processes can only have been active for no more than only $\sim 50,000$ years, based on elevation differences of the Matahina ignimbrite top surface.

- The disparity between emplacement of coherent rhyolite as sills at $0.36 \mathrm{Ma}$ and dikes at $0.138 \mathrm{Ma}$ reflects a shift in orientation of the principal stress axes in response to initiation of the modern TVZ rifting regime and the onset of the modern Whakatane Graben.

Although previously inferred to be a long-lived system, the modern Kawerau Geothermal Field is a Holocene entity reflecting the rejuvenation of magmatic heat flux associated with Putauaki volcano superimposed on an area of multiple reactivated fault structures, sporadic magmatism and variable rates of subsidence. This study documents past patterns of fluid flow, temperatures and chemistry, and inferred permeability within the field. Using textural relationships in selected samples, the relative timing and patterns of hydrothermal alteration, and fluid flows can be established. These textural relationships are then calibrated against fluid inclusion palaeotemperature measurements and isotope data and related to temperatures and compositions of past fluids. Short-lived heat sources beneath the field resulted from local magma intrusions, and are responsible for the $0.36 \mathrm{Ma}$ and $0.138 \mathrm{Ma}$ rhyolites and Holocene eruptive activity of Putauaki andesite-dacite volcano. The Putauaki activity is inferred to be responsible for the thermal and alteration characteristics of the modern system. 


\section{ACKNOWLEDGEMENTS}

Firstly I would like to thank my primary supervisor, Colin Wilson for guiding me and sharing his knowledge, it has been a pleasure to work with you. I also thank my co-supervisor Greg Bignall for many random questions and discussions, I'm sure you will be happy with me not knocking on your door so frequently. Thanks also go to my co-authors on papers published from this work, Ben Pezaro, Bruce Charlier, Joe Wooden, Trevor Ireland and Candice Bardsley, your comments and discussions were invaluable.

I would like to acknowledge funding support from Mighty River Power Ltd. and a Doctoral Research Scholarship from Victoria University which made this work possible. Additional funding came from support to CJNW and GB via the GNS Science CSA (Core Science Area) Geothermal Research Programme. Additional funding for CJNW came from the FRST Programme "Deep Geothermal Resources" through subcontracts from The University of Auckland, by courtesy of Mike O’Sullivan.

I would like to thank Mighty River Power Ltd, along with that of Ngati Tuwharetoa Geothermal Assets Ltd, for permission to publish the data used in this thesis. Thanks also go to A8D Trust, Putauaki Trust, Te Tahuna Putakuaki Trust and other local Maori trusts for access to well core and cuttings, and Darren Gravley for the Onepu Dome sample.

Simon Barker and Nick Burrows undertook the mineral separations. Peter Holden, Brad Ito and Jorge Vazquez are thanked for their help at various stages in obtaining the ion probe age determinations at the USGS-Stanford University and Australian National University facilities. Samantha Alcaraz for help with learning how to drive Leapfrog Geothermal and editorial comments on the paper submitted for the 3-D modelling. Thanks to Aranz Geo Ltd. for a Leapfrog Geothermal research license which allowed me to undertake 3-D modelling. Thanks also to Michael Rosenberg for valuable comments and discussion on Kawerau related things in general, Mark Simpson for discussions on fluid inclusion microthermometry and Isabelle Chambefort and Kevin Faure for discussion and editorial comments on stable isotope data.

Thanks to Sally Potter for being a fantastic office mate and support and Nellie Olsen for many skiing and tramping adventures. Melissa Rotella, Simon Barker, Alexa Van Eaton, Katy Chamberlain, George Cooper, Aidan Allan and many others at the uni, thanks for you guidance (particularly as a remote student).

Finally to Mum, Dad and Ross, thank you for your love, support and encouragement. I couldn't have done it without you. 


\section{DEDICATION}

To Mum and Dad

...endless support... 


\section{CONTENTS}

\begin{tabular}{|c|c|c|c|}
\hline \multicolumn{4}{|l|}{ ABSTRACT } \\
\hline \multicolumn{4}{|c|}{ 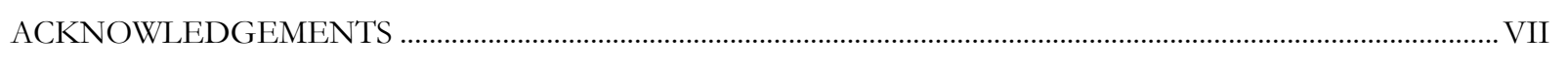 } \\
\hline \multirow{2}{*}{\multicolumn{4}{|c|}{ 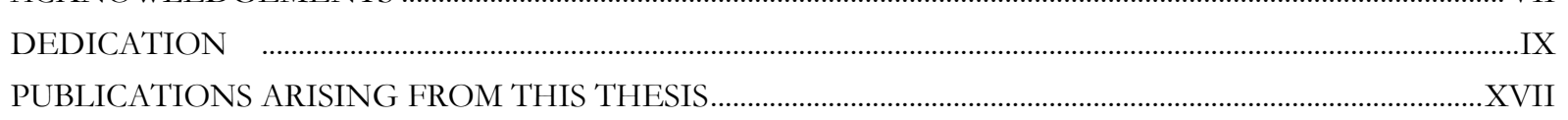 }} \\
\hline & & & \\
\hline \multirow[t]{17}{*}{ CHAPTER 1} & \multicolumn{3}{|c|}{ THESIS INTRODUCTION } \\
\hline & 1.1 & Thesi & butline \\
\hline & & 1.1 .1 & 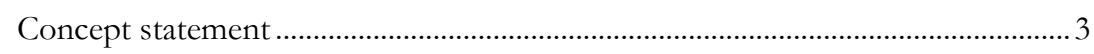 \\
\hline & & 1.1 .2 & Background and motivation of study .................. \\
\hline & & 1.1 .3 & 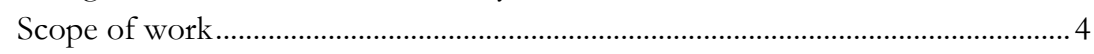 \\
\hline & 1.2 & \multicolumn{2}{|r|}{ Geothermal systems } \\
\hline & 1.3 & \multicolumn{2}{|r|}{ 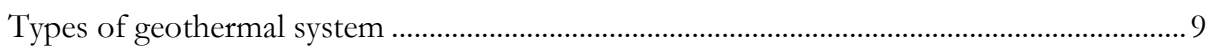 } \\
\hline & 1.4 & \multicolumn{2}{|r|}{ 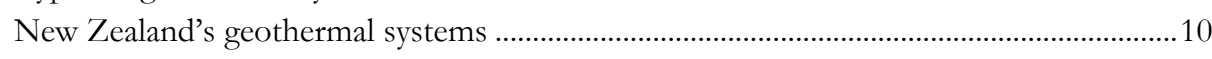 } \\
\hline & 1.5 & \multicolumn{2}{|r|}{ 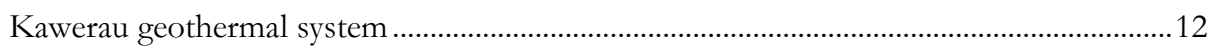 } \\
\hline & & 1.5 .1 & 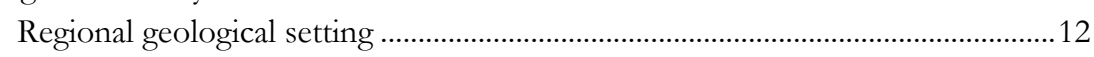 \\
\hline & & 1.5 .2 & 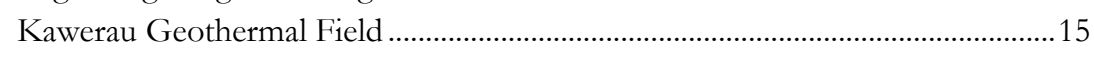 \\
\hline & & 1.5 .3 & 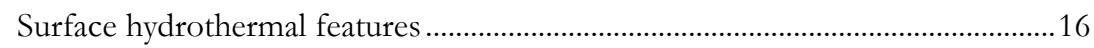 \\
\hline & & 1.5 .4 & 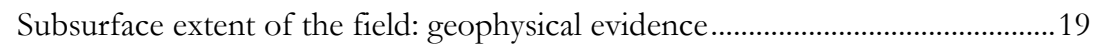 \\
\hline & & 1.5 .5 & Kawerau geology \\
\hline & & 1.5.6 & 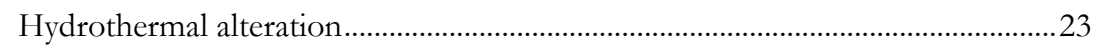 \\
\hline & & 1.5 .7 & Conceptual model of the Kawerau Geothermal Field .............................................26 \\
\hline & 1.6 & \multicolumn{2}{|r|}{ 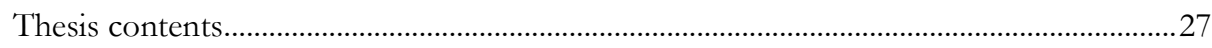 } \\
\hline
\end{tabular}

CHAPTER 2 U-PB DATING OF ZIRCON IN HYDROTHERMALLY ALTERED ROCKS OF THE KAWERAU GEOTHERMAL FIELD, TAUPO VOLCANIC ZONE, NEW ZEALAND ....... 31

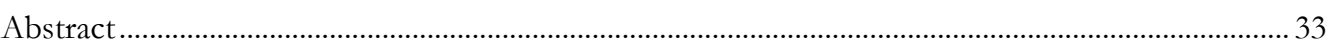

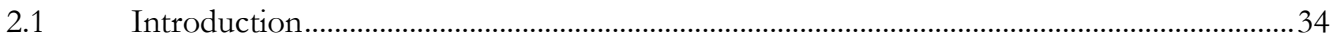

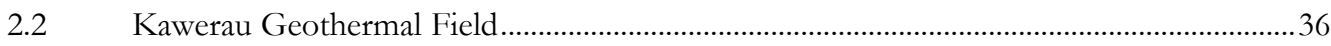

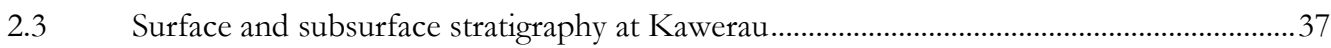

2.4 Samples and analytical methods ............................................................................................. 40

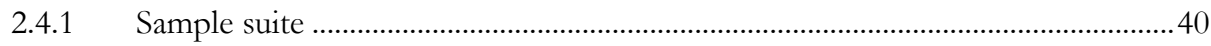

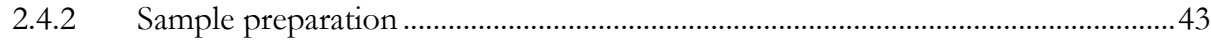

2.4.3 Ion probe analytical techniques for ion probe ............................................................ 43

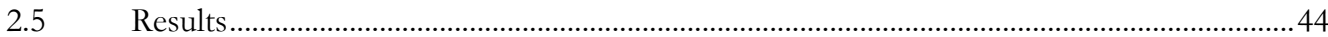

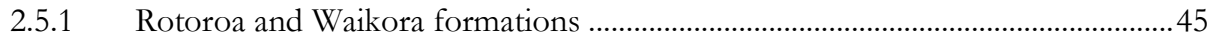

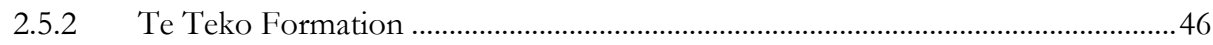

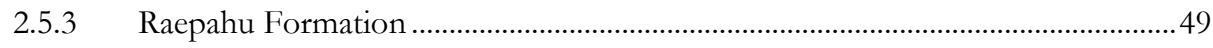

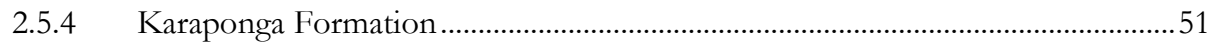

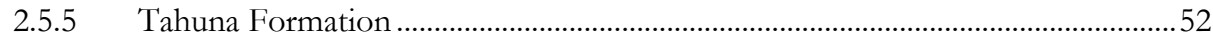

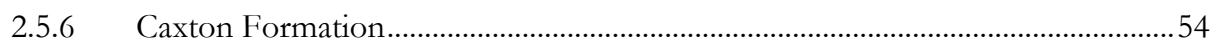

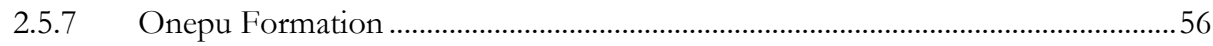

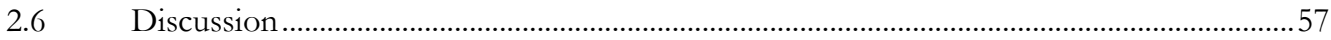

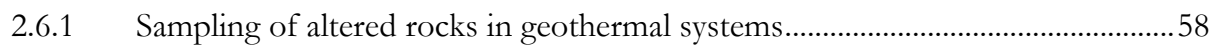

2.6.2 Local magmatism at Kawerau versus distal volcanism ...........................................59

2.6.3 Subsidence rates and tectonic processes at Kawerau ...............................................60

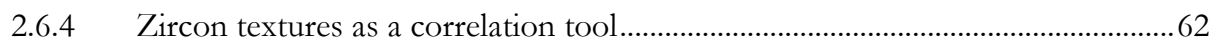

2.6.5 Ignimbrite groupings at Kawerau and comparisons with TVZ eruption

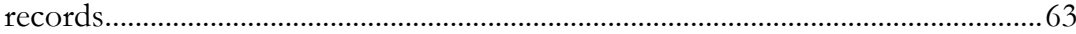

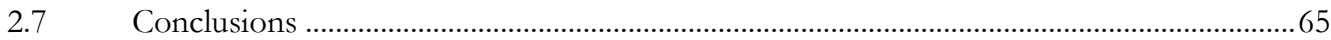

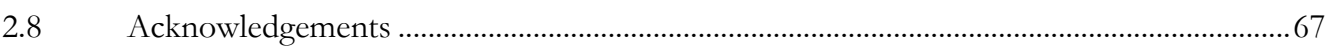

CHAPTER 3 RECONSTRUCTING THE GEOLOGICAL AND STRUCTURAL HISTORY OF AN ACTIVE GEOTHERMAL FIELD: A CASE STUDY FROM NEW ZEALAND .......................69

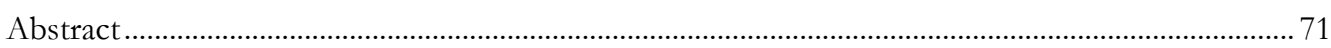


3.2 Geological framework for the Kawerau system ................................................................. 73

3.2.1 Latest Quaternary units .................................................................................... 78

3.2.2 Onepu Formation extrusive domes and intrusive bodies ..................................... 79

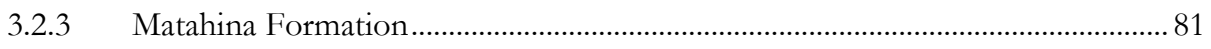

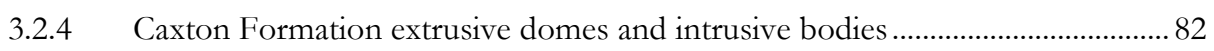

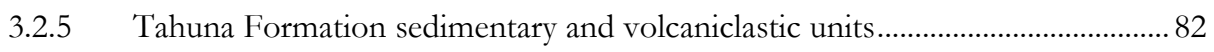

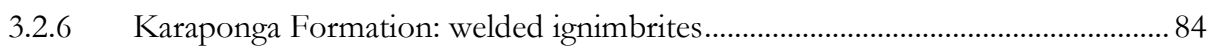

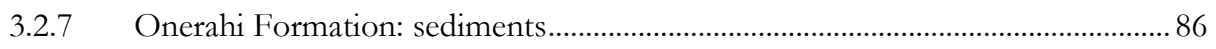

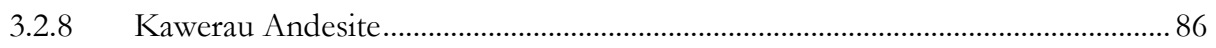

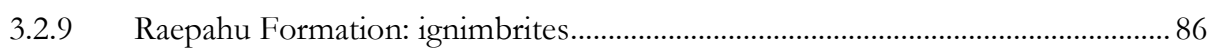

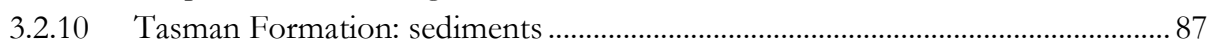

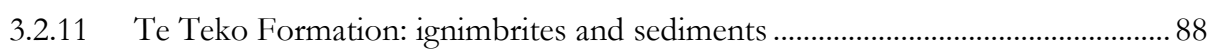

3.2.12 Tamurenui Subgroup (Rotoroa and Waikora formations) ..................................... 88

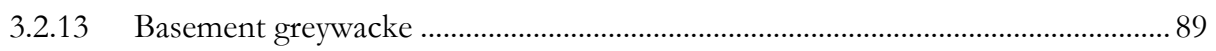

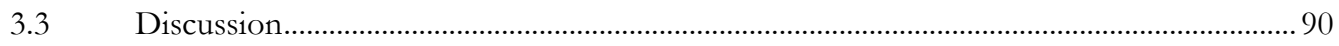

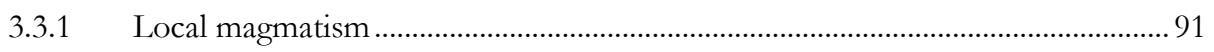

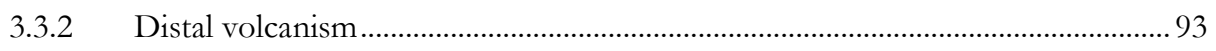

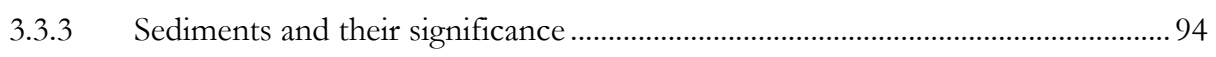

3.3.4 Faulting and subsidence....................................................................................... 96

3.3.5 Challenges in recognition of rock types in hydrothermal altered

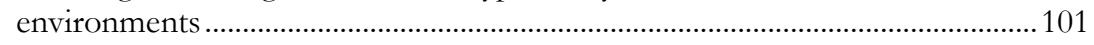

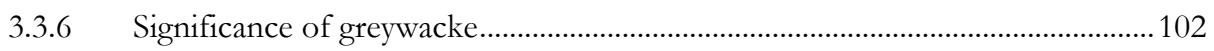

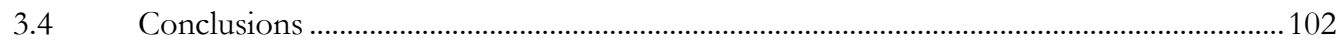

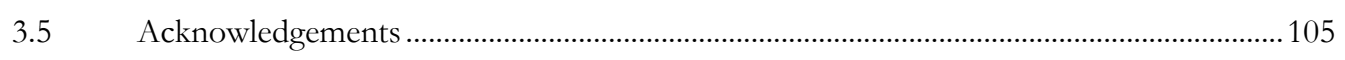

CHAPTER 4 3-D INTERPRETATIVE MODELLING APPLIED TO THE GEOLOGY OF THE KAWERAU GEOTHERMAL SYSTEM, TAUPO VOLCANIC ZONE, NEW ZEALAND . 107

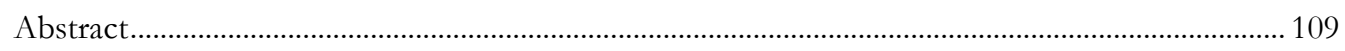

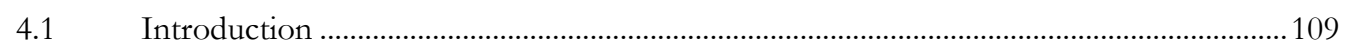

4.2 Setting of the Kawerau geothermal system ........................................................................ 110

4.3 Modelling the Kawerau geothermal system.......................................................................... 111

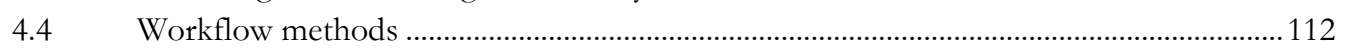

4.5 Kawerau geothermal system 3-D model ................................................................................... 114

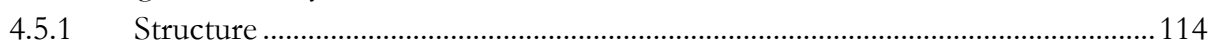

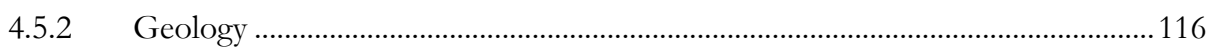

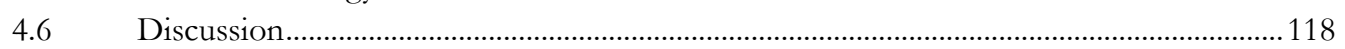

4.6.1 An integrated approach to modelling and stratigraphic correlation .................... 118

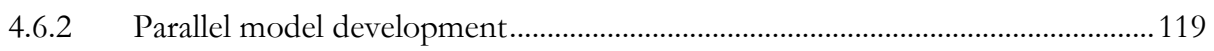

4.6.3 Management tools from 3-D modelling ................................................................. 120

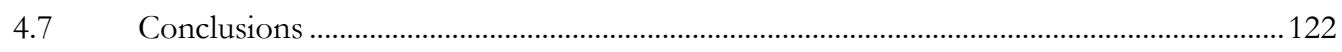

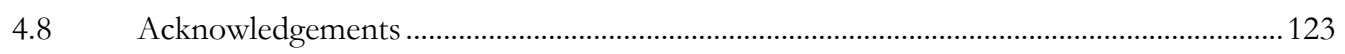

CHAPTER 5 HYDROTHERMAL-MAGMATIC INFLUENCES ON THE GEOTHERMAL SYSTEM... 125

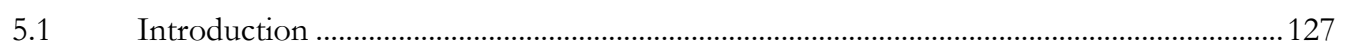

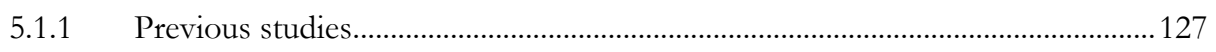

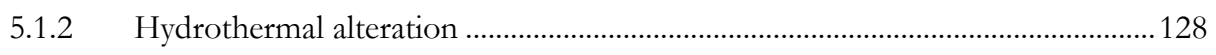

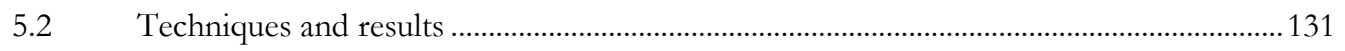

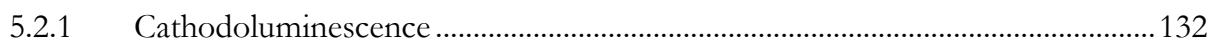

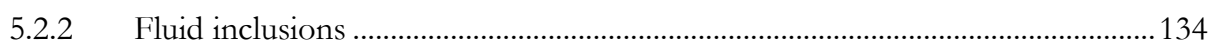

5.2.2.1 Fluid inclusion methodology ............................................................... 135

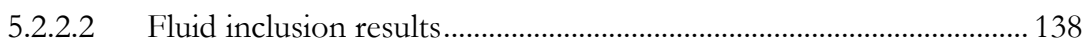

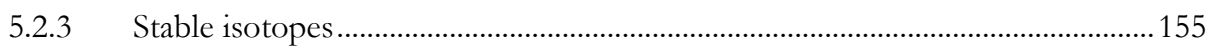

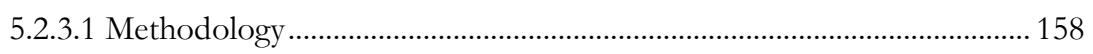

5.2.3.2 Stable isotope results ............................................................................. 159 


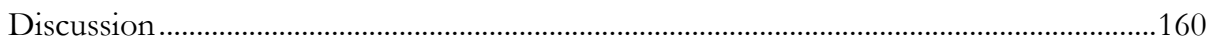

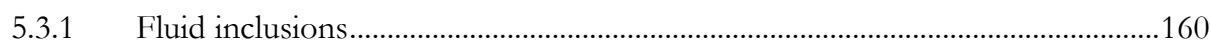

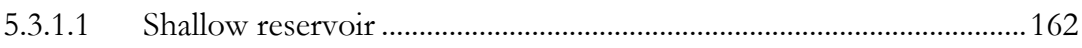

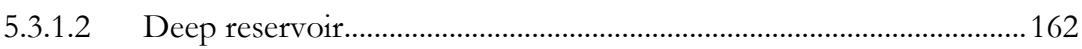

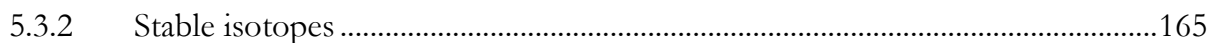

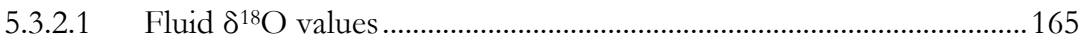

5.3.2.2 Calcite $\delta^{18} \mathrm{O}$ values ............................................................................. 168

5.3.2.3 Quartz $\delta^{18} \mathrm{O}$ values........................................................................... 170

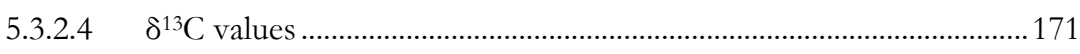

5.3.2.5 Alteration events and chronostratigraphy ........................................... 171

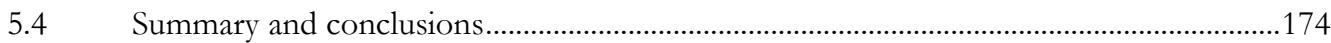

CHAPTER 6 SUMMARY AND CONSIDERATIONS FOR FURTHER WORK …………………................177

6.1 Summary of results obtained in this work ..............................................................................179

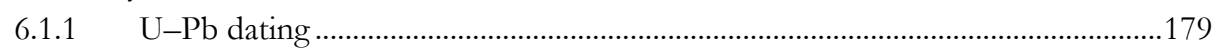

6.1.2 Geological architecture .................................................................................. 180

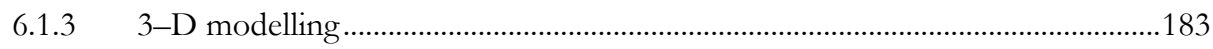

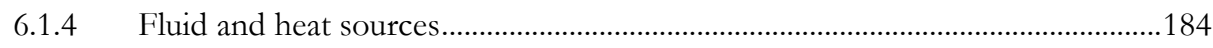

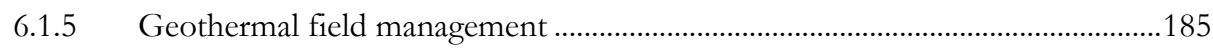

6.2 Answers to the key questions posed in this thesis .............................................................185

6.3 Further questions and future work ................................................................................191

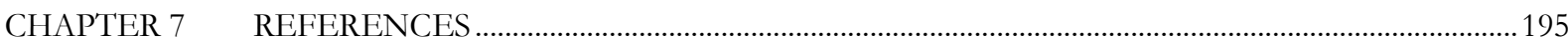

\section{FIGURES}

Figure 1.1

Figure 1.2

Figure 1.3

Figure 1.4

Figure 1.5

Figure 1.6

Figure 1.7

Figure 1.8

Figure 1.9

Figure 1.10

Figure 2.1

Figure 2.2

Figure 2.3

Figure 2.4

Figure 2.5

Figure 2.6

Figure 2.7
Schematic representation of an ideal geothermal system. 9

Schematic models and descriptions of the main types of geothermal systems. .................................. 10

Distribution of thermal springs, active volcanoes and the main active fault zones in New Zealand. 11

Structural map of the Taupo Volcanic Zone............................................................................................. 13

Number of wells drilled per year at Kawerau from 1952 to 2012

Locations of the main thermal areas, geothermal wells, and the resistivity boundary zone of the Kawerau Geothermal Field

Contour of apparent resistivity (in $\Omega \mathrm{m}$ ) using Schlumberger electrode spacing $\mathrm{AB} / 2=$ $1000 \mathrm{~m}$ (nominal), from Allis (1997).

Map of Kawerau Geothermal Field showing drillholes, active faults), lower eruption breccia isopachs and approximate resistivity boundary zone at about $500 \mathrm{~m}$ depth .........................2 22

Temperature stabilities of common hydrothermal (secondary) minerals ............................................ 24

Conceptual model of the Kawerau Geothermal Field ........................................................................2 27

Locality map for the Taupo Volcanic Zone (TVZ) with the Kawerau Geothermal Field ................. 37

Map of Kawerau Geothermal Field showing drillholes, active faults, and approximate resistivity boundary zone at about $500 \mathrm{~m}$ depth

Summary stratigraphic log of main geology units in Kawerau Geothermal Field with location and ages of dated samples......

Histogram and relative probabilities for samples SA740 and KATY824 from ignimbrites within the Rotoroa Formation.....

Histogram and relative probabilities for samples SALLY576, DE608, KA23-1, BOB822, DA705, ST906 and AN1101 from samples in the Te Teko Formation

Histogram and relative probabilities for samples BRUCE457, AI780, KA23-2 and P1722 (Kidnappers Ignimbrite) comparing samples within the Raepahu Formation with a surficial sample of Kidnappers ignimbrite.

Histogram and relative probabilities for samples ROSS608, RO610 within the Karaponga Formation at Kawerau and P1904 which is from pumice in outwash fluvial sediments from the Quartz-biotite ignimbrite of Nairn (2002)... 
Figure 2.9 Stacked histograms for all samples labelled as Caxton Formation rhyolite, grouped into (a) crystal-poorer $(\sim 5 \%)$ and (b) crystal-richer variants.

Figure 2.10

Figure 2.11

Figure 2.12

Figure 2.13

Figure 2.14

Figure 3.1

Figure 3.2

Figure 3.3

Figure 3.4

Figure 3.5

Figure 3.6

Figure 3.7

Figure 3.8

Figure 3.9

Figure 3.10

Figure 4.1

Figure 5.1

Figure 5.2

Figure 5.3

Figure 5.4

Figure 5.5

Figure 5.6

Figure 5.7

Figure 5.8

Figure 5.9

Figure 5.10

Figure 5.11

Figure 5.12

Figure 5.13

Figure 5.14
Age data for zircons from two samples (JA885; J2667) inferred to be from the subsurface feeder to the surficial Onepu dome rhyodacite (D068) with stacked

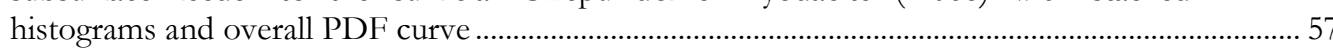

Cross sections from northwest to south southeast across the Kawerau Geothermal Field...

Plot of the depths of various stratigraphic units at Kawerau versus their ages from zircon ages.

Representative of zircon textures.

Cumulative thickness $(\mathrm{cm})$ of the 37 TVZ-derived tephra eruptive units at Site 1123 plotted against time (Ma) Also shown are the known periods of activity represented by the eight caldera centres within the central TVZ and the ages of tuffs in the Kawerau Geothermal Field.

Locality and structural map of the local Kawerau area.

Map of Kawerau Geothermal Field showing drillholes, active faults, and approximate resistivity boundary zone defined at about $500 \mathrm{~m}$ depth. Geology map units are after Leonard et al. (2010)

Summary comparative stratigraphic logs of the main geology units in Kawerau geothermal system...

Example images of hydrothermally altered intrusive and extrusive coherent rhyolite of the Onepu $(0.138 \mathrm{Ma})$ and Caxton $(0.36 \mathrm{Ma})$ formations at Kawerau.

3-D geological model of the Kawerau geothermal system, highlighting the extent of the Kawerau Andesite, Caxton Formation and Onepu Formation.

Example images of hydrothermally altered sedimentary rocks at Kawerau. ............................................ 83

Example images of hydrothermally altered ignimbrite at Kawerau. .................................................... 85

3-D geological representation of the Kawerau geothermal system, with the development of structure and stratigraphy through time.

Cross sections showing the development of faulting in the Kawerau geothermal system over time.

Approximate cumulative fault displacements determined from the offset in the tops of the units at this time period.

Left: location of TVZ high-temperature $\left(>200{ }^{\circ} \mathrm{C}\right)$ geothermal systems defined by geophysics and/or drilling, outcrops of greywacke, active faults and TVZ boundary. Right: Kawerau Geothermal Field, with approximate resistivity boundary zone at about $500 \mathrm{~m}$ depth, location of wells and active faults

Location of wells in the Kawerau Geothermal Field, with wells sampled for fluid inclusions and stable isotopes highlighted.

Schematic illustration of interactions of an electron beam with a solid surface.

Published examples of CL imagery in hydrothermal quartz highlighting growth and dissolution events

Schematic representation showing the formation of primary, secondary and pseudosecondary inclusions during crystal growth.

Representative fluid inclusions from several wells in the Kawerau Geothermal Field...

Mean homogenisation $\left(\mathrm{T}_{\mathrm{h}}\right)$ and melting $\left(\mathrm{T}_{\mathrm{m}}\right)$ temperatures for FIA in KA21 with corresponding CL image.

Fluid inclusion results from KA21.

Mean homogenisation $\left(T_{h}\right)$ and melting $\left(T_{m}\right)$ temperatures for FIA in KA23 with corresponding CL image...

Fluid inclusion results from KA23.

Fluid inclusion results from KA26.

Fluid inclusion results from KA28.

Mean homogenisation $\left(\mathrm{T}_{\mathrm{h}}\right)$ and melting $\left(\mathrm{T}_{\mathrm{m}}\right)$ temperatures for FIA at $885 \mathrm{mRF}$ in

KA30 with corresponding CL image.

Fluid inclusion results from KA30. 
Figure 5.15

Figure 5.16

Figure 5.17

Figure 5.18

Figure 5.19

Figure 5.20

Figure 5.21

Figure 5.22

Figure 5.23

Figure 5.24

Figure 6.1

Figure 6.2

Video Still 1

Video Still 2

Mean homogenisation $\left(T_{h}\right)$ and melting $\left(T_{m}\right)$ temperatures for FIA in KA47 with corresponding CL image.

Fluid inclusion results from KA47.

Fluid inclusion results from KA48.

$\delta \mathrm{O}^{18}$ and $\delta \mathrm{D}$ values of hot-spring, fumarole and drillhole fluids derived from meteoric water and of meteoric water local to each system.

Histogram of the $\delta^{18} \mathrm{O}_{\text {VSMOW }}$ values of quartz and calcite and the $\delta^{13} \mathrm{C}_{\mathrm{VPDB}}$ values of calcite.

Selection of typical temperature profiles from the drilled part of the Kawerau Field.

$\delta^{18} \mathrm{O}$ values of the calculated fluids in equilibrium with quartz and calcite using measured temperature ranges.

$\delta^{18} \mathrm{O}$ values in calcite plotted as a function of depth.

Calculated $\delta^{18} \mathrm{O}_{\mathrm{H} 20}$ vs. $\delta^{13} \mathrm{C}_{\mathrm{CO} 2}$ values from calcite plotted as a function of depth.

Inferred variations in calculated $\delta^{18} \mathrm{O}$ fluid isotopic values during the history of the Kawerau geothermal system.

Cartoon depiction of the geology in the Kawerau geothermal system with the approximate age of the geological units.

Schematic cartoons with the development of thermal flux beneath the Kawerau Geothermal Field.

\section{VIDEO STILLS}

(Electronic Appendix 5) Structural network of inferred faults used in the construction of the 3-D geology model of the Kawerau geothermal system. The key applies to the video file

(Electronic Appendix 6) 3-D geological visualisation of the Kawerau geothermal system. The key applies to the video file.

\section{TABLES}

Table 1.1

Table 1.2

Table 2.1

Table 2.2

Table 2.3

Table 2.4

Table 2.5

Table 2.6

Table 3.1

Table 3.2

Table 4.1

Table 5.1

Table 5.2

Table 5.3

Table 5.4

Table 5.5
Hydrothermal alteration intensity. .25

Hydrothermal alteration assemblages and their associated minerals.

Summary of the main stratigraphic units and lithologies in the Kawerau Geothermal

Field.

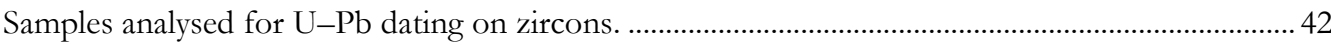

Summary of age parameters for ignimbrites of the Te Teko Formation............................................. 47

Summary of age parameters for ignimbrites of the Raepahu Formation. ............................................. 50

Summary of age parameters for ignimbrites of the Karaponga and Tahuna formations. .................. 53

Summary of age parameters for coherent rhyolite units of the Caxton Formation. .......................... 55

Summary of the main stratigraphic units and lithologies in the Kawerau geothermal system.

Translation table from the previous stratigraphy summarised in Bignall and Harvey (2005) to the stratigraphy described in this paper.

Summary of the main stratigraphic units and lithologies in the Kawerau Geothermal Field.

Kawerau hydrothermal mineral samples selected and hand-picked for analyses.

Fluid inclusion microthermometry results from quartz and bladed calcite samples collected from well KA21 and KA21ST drill cuttings.

Fluid inclusion microthermometry results from quartz and bladed calcite samples collected from well KA23 drill cuttings.

Fluid inclusion microthermometry results from quartz and bladed calcite samples, collected from well KA26 drill cuttings.

Fluid inclusion microthermometry results from quartz collected from well KA28 drill cuttings. 
Table 5.6 Fluid inclusion microthermometry results from quartz and bladed calcite samples, collected from well KA30 drill cuttings..

Table 5.7 Fluid inclusion microthermometry results from quartz samples, collected from well KA47 drill cuttings.

Table $5.8 \quad$ Fluid inclusion microthermometry results from quartz and bladed calcite samples collected from well KA48 drill cuttings..

Table 5.9 Carbon and oxygen stable isotope values for selected Kawerau samples.

Table 5.10 $\quad \delta^{18} \mathrm{O}_{\mathrm{H} 2 \mathrm{O}}$ in equilibrium with Kawerau quartz and calcite samples at tabulated temperature ranges.

Table 5.11

$\delta^{13} \mathrm{C}_{\mathbf{H} 2 \mathrm{CO} 3}$ in equilibrium with Kawerau calcite samples at tabulated temperature ranges. 167

\section{APPENDICES}

APPENDIX A Graphical well logs 223

\section{APPENDIX FIGURES}

Figure A1 Map of Kawerau Geothermal Field showing drillholes, active faults, and approximate resistivity boundary zone defined at about $500 \mathrm{~m}$ depth 225

\section{ENCLOSURES}

CD

Electronic Appendix 1: Kawerau Geothermal Field well logs

Electronic Appendix 2: Petrographic of selected samples from the Kawerau Geothermal Field

Electronic Appendix 3: Conference publications

Electronic Appendix 4: Full sample suite of SHRIMP-RG U-Pb ages

Electronic Appendix 5: Video file of the 3-D visualisation of the faulting structure in the Kawerau geothermal system

Electronic Appendix 6: Video file of the 3-D visualisation of the geology of the Kawerau geothermal system

Electronic Appendix 7: Fluid inclusion plates

Electronic Appendix 8: Fluid inclusion microthermometry raw data

Electronic Appendix 9: Summary fluid inclusion plane light and cathodoluminescence images back cover 


\section{PUBLICATIONS ARISING FROM THIS THESIS}

\section{Journal articles}

Milicich, S.D., Wilson, C.J.N., Bignall, G., Pezaro, B., Charlier, B.L.A., Wooden, J.L., Ireland, T.R., 2013. U-Pb dating of zircon in hydrothermally altered rocks of the Kawerau Geothermal Field, Taupo Volcanic Zone, New Zealand. Journal of Volcanology and Geothermal Research 253, 97-113. Presented in Chapter 2.

Milicich, S.D., Wilson, C.J.N., Bignall, G., Pezaro, B., Bardsley, C., 2013. Reconstructing the geological and structural history of an active geothermal system: a case study from New Zealand. Journal of Volcanology and Geothermal Research 262, 7-24. Presented in Chapter 3.

Milicich, S.D., Bardsley, C., Bignall, G., Wilson, C.J.N., 2013. 3-D interpretation of the geology of the Kawerau geothermal system, Taupo Volcanic Zone, New Zealand. Under review with Geothermics. Presented in Chapter 4.

\section{Science Reports}

Milicich, S.D., 2013. Petrography of selected samples from the Kawerau Geothermal Field. GNS Science Report, 2013/05. Presented in Electronic Appendix 2.

Milicich, S.D., 2013. Kawerau Geothermal Field well logs. GNS Science Report, 2013/06. Presented in Electronic Appendix 1.

Bignall, G.; Milicich, S.D., 2012 Kawerau Geothermal Field: geological framework. GNS Science report 2012/33.

\section{Conference papers (*indicates oral presentation)}

*Milicich, S.D., Wilson, C.J.N., Bignall, G., Pezaro, B., Charlier, B.L.A., Wooden, J.L., Ireland, T.R., 2011. Buried rhyolite in the Kawerau Geothermal Field, Taupo Volcanic Zone, New Zealand: sources of a rejuvenated geothermal system. Proceedings of the $33^{\text {rd }}$ New Zealand Geothermal Workshop, Auckland, New Zealand, 21-23 November 2011, paper 31. Presented in Electronic Appendix 3.1. 
*Milicich, S.D., Wilson, C.J.N., Bignall, G., Pezaro, B., Bardsley, C., Charlier, B.L.A., Wooden, J.L., Ireland, T.R., 2012. U-Pb dating of zircon in hydrothermally altered rocks as a correlation tool: a case study from the Kawerau Geothermal Field, New Zealand. Proceedings of the $34^{\text {th }}$ New Zealand Geothermal Workshop, Auckland, New Zealand, 19-21 November 2012. Presented in Electronic Appendix 3.2.

*Milicich, S.D., Wilson, C.J.N., Bignall, G., Pezaro, B., Bardsley, C., 2013. An integrated approach to correlation of geology in geothermal systems: a case study from the Kawerau Geothermal Field, New Zealand. Proceedings of the $35^{\text {rd }}$ New Zealand Geothermal Workshop, Rotorua, New Zealand, 17-20 November 2013. Presented in Electronic Appendix 3.3.

*Alcaraz, S.A.; Lane, R.; Spragg, K.; Milicich, S.D.; Sepulveda, F.; Bignall, G., 2011. 3D geological modelling using new Leapfrog Geothermal software. Proceedings, $36^{\text {th }}$ Workshop Geothermal Reservoir Engineering, January 31 - February 2, 2011, Stanford University. Stanford, USA. Stanford Geothermal Program Workshop report SGP-TR191, 351-356. Presented in Electronic Appendix 3.4.

\section{Conference abstracts (*indicates oral presentation)}

Milicich, S.D., Wilson, C.J.N., Bignall, G., Pezaro, B., 2012. Buried rhyolite in the Kawerau Geothermal Field, Taupo Volcanic Zone, New Zealand: sources of a rejuvenated geothermal system. US/NZ Joint Geothermal Workshop. Rotorua, New Zealand. Presented in Electronic Appendix 3.5.

Milicich, S.D., Wilson, C.J.N., Bignall, G., Pezaro, B., 2012. Local magmatic episodes and heat sources for hydrothermal activity in the Kawerau Geothermal Field, Taupo Volcanic Zone, New Zealand. American Geophysical Union Fall Meeting, San Francisco, USA. Abstract V13A-2809. Presented in Electronic Appendix 3.6.

*Milicich, S.D., Wilson, C.J.N., Bignall, G., Pezaro, B., Clark, J., 2013. U-Pb dating of zircon as an aid in interpretation of geothermal systems: a case study from the Kawerau Geothermal Field, New Zealand. IAVCEI 2013, Kagoshima, Japan. Presented in Electronic Appendix 3.7. 
Wilson, C.J.N., Charlier, B.L.A., Rowland, J.V, Browne, P.R.L., Milicich, S.D., Bignall, G., 2010. Zircon age patterns in TVZ buried and hydrothermally-altered rocks: A progress report. GeoNZ 2010 Conference, Auckland, New Zealand. Geoscience Society of New Zealand Miscellaneous Publication 129A, p.320. Presented in Electronic Appendix 3.8. 

CHAPTER 1

THESIS INTRODUCTION 
Chapter 1 


\subsection{THESIS OUTLINE}

\subsubsection{Concept statement}

The work focuses on the use of U-Pb dating techniques on zircon, coupled with a comprehensive revision of stratigraphic correlations and complemented by hydrothermal alteration studies, to resolve the hydrothermal system evolution, basin development and geological controls on fluid flow in the Kawerau geothermal system. The age determinations are used to constrain the volcanic stratigraphy that forms the upper $1 \mathrm{~km}$ of the system above the greywacke basement. From this revised stratigraphic framework, an improved understanding of the evolution is derived of structural features (faulting and subsidence rates) and fluid pathways in the greywacke basement in both producing and non-producing parts of the field. The research will provide the basic information for an improved regime of field management and underpin future development strategies.

\subsubsection{Background and motivation of study}

Management and development of the Kawerau Geothermal Field demands accurate knowledge of the local geological conditions, particularly where they impact on the hydrology of the high-temperature resource. The current situation in the Kawerau Geothermal Field involves multiple parties having interests in the resource. Currently Ngāti Tuwharetoa Geothermal Assets, Norske Skog Tasman and Mighty River Power Ltd. are party to a Geothermal Steamfield Management Agreement which provides for the general principles and plan compliance processes, to ensure the on-going sustainable management and integrated development of the Kawerau geothermal resource. Geothermal take, use and discharge permits are required under the Resource Management Act (RMA) for any expansion to existing steam supply operations. A robust understanding of the geology and permeability/fluid pathways within the Kawerau geothermal system feeds into many aspect of defending applications for increased or new steam supply under the RMA.

This study is an integrated programme of work using multiple techniques to develop new perspectives on the geological framework of the Kawerau geothermal resource. In this body of work the term 'Kawerau geothermal system' is used to refer to the natural entity, and 'Kawerau Geothermal Field' to refer to the geothermal resource and the infrastructure and land boundaries associated with the geothermal power station. 
The geology of the area around the Kawerau geothermal system is superficially straightforward, with a succession of volcanic rocks and volcaniclastic sediments overlying basement greywacke. The resource is controlled by structures in the basement rocks, and current drilling strategies target permeability related to faulting and fracturing in the greywacke. The locations, however, of the basement faults, their offsets and history of movement and the geological controls on the thermal fluid upflows are not well understood. Similarly, the age of the Kawerau geothermal system is poorly constrained. The present hydrological structure of the field is consistent with the highest temperatures measured in wells being controlled by the magmatic source for the Putauaki andesite-dacite cone. Its eruptive activity is bracketed by ${ }^{14} \mathrm{C}$ ages of 9,500 cal. years B.P. on an underlying regional rhyolite fall deposit (Rotoma tephra: Lowe et al., 2013) and 3,400 cal. years B.P. on late-stage block-avalanche deposits (Carroll et al., 1997), while breccias of inferred hydrothermal eruption origin (Browne, 1979) occur below the $322 \pm 7$ ka Matahina ignimbrite. This study programme resolves these uncertainties around the age of the field, based on a new understanding of the structural evolution of the greater Kawerau area.

Although the geological approaches and techniques utilised in the study are well established, their application to an integrated study of a geothermal system in New Zealand has not been previously undertaken. Petrographic studies to determine stratigraphic correlations and fluid inclusion analyses to determine fluid chemistry and temperature are commonly applied to the development and understanding of geothermal fields. What is novel in the New Zealand context is taking these data and integrating them with a comprehensive dating programme, and then using this information to inform and create a model 3-D visualisation of a geothermal field. Although 3-D geologic modelling has routinely been applied in the petroleum industry, this is still relatively new to the geothermal industry.

\subsubsection{Scope of work}

This PhD addresses several key questions in order to understand and model the geological and structural development of the Kawerau area. Although set out separately, it is important to recognise that these questions are closely intertwined and that research addressing any one question will inform the others. As a consequence, an overall 4-D visualisation of the Kawerau geothermal system will be developed within a broader context of the volcanic and structural evolution of the Taupo Volcanic Zone (TVZ). The key questions for this study are as follows. 
- What are the ages of major stratigraphic units?

Although only $\sim 1 \mathrm{~km}$ thick, the volcanic/sedimentary rock pile represents the key to understanding and modelling the basement greywacke structure. Key stratigraphic units, both at the surface and in the subsurface, were dated by U-Pb dating of zircon using Sensitive High-Resolution Ion Microprobe (SHRIMP) instruments at Stanford University and the Australian National University. Coupled with revised geological correlations, an accurate history of subsidence across the field was constructed and the rates of displacement across key faults were inferred from the new age data of correlatable stratigraphic units. Coupled with modern geodetically determined rates of faulting, knowledge of fault displacement histories and displacement rates is critical to understanding of the location, cause and history of permeability pathways within the Kawerau Geothermal Field. A detailed suite of age information has significantly improved models of faulting behaviour within the Kawerau Geothermal Field.

- What is the geological history of the field and its internal stratigraphic and structural relationships?

Correlations between stratigraphically definable units across the greater Kawerau Field are re-examined, as existing correlations had been proven to be demonstrably in error in several important parts of the field. A systematic programme of petrographic studies was undertaken to set out the correlations with more confidence and provide a consistent suite of descriptions and correlations that can be used in subsequent modelling and drilling efforts. A better data set of depths to the top or bottom of key stratigraphic horizons (particularly if the top surface was originally sub-horizontal, such as in the case of a welded ignimbrite) allows fault displacements to be measured more accurately across the overall field.

- How has the thermal and chemical regime changed in the system and how does this reflect its hydrology and evolution?

The study documents past patterns of fluid flow, temperatures and chemistry, and inferred permeability within the field. Using textural relationships in selected samples, the relative timing and patterns of hydrothermal alteration, and fluid flows was established. These textural relationships are then calibrated against fluid inclusion palaeotemperature measurements and isotope data and are related to temperatures and compositions of past fluids. 
These questions are addressed within six interrelated chapters, developed around the central theme of creating a coherent stratigraphic and structural framework for the Kawerau area. The chapters are written in a style suitable for publication, and are presented as self-contained studies. Published or accepted versions have been modified only slightly in terms of style and formatting for incorporation into a consistent overall thesis design.

\subsection{GEOTHERMAL SYSTEMS}

The heat generated internally in the Earth, largely through decay of naturally radioactive elements, is conducted to the surface along a geothermal gradient which is normally between 15 and $30^{\circ} \mathrm{C} / \mathrm{km}$ (Thain et al., 2006). Along with the natural heat flow are localised areas of higher temperatures associated with volcanic activity. This occurs where two tectonic plates move apart, such as mid-ocean ridges; collide, such as in New Zealand where one plate is subducted beneath another; or in "hot spots" under mid-ocean volcanic islands such as Hawaii. In New Zealand, through the actively rifting TVZ, thinning of the crust, and associated involvement of magma at depth, results in anomalously high geothermal gradients.

Heat from the Earth's interior can be used as an energy source, known as geothermal energy. The Earth's heat content is $10^{31}$ joules (Friedleifsson et al., 2008). This heat naturally flows to the surface by conduction at a rate of 44.2 TW (Pollack et al., 1993) and is replenished by radioactive decay at a rate of 30 TW (Rybach, 2007). These power rates are more than double current energy consumption from primary sources, but most of this power is too diffuse (approximately $0.1 \mathrm{~W} / \mathrm{m}^{2}$ on average) to be recoverable (Rybach, 2007).

In regions of high heat flow, or where magma bodies are close to the surface, the hightemperature gradients heat deeply percolating groundwater (through deep faults, rock fractures and pores) which drives a convecting hydrothermal system. A basic hydrothermal system is made up of a geothermal reservoir and the geothermal system. The reservoir is a volume of rocks from which heat can be extracted. This is surrounded by cooler rocks that are hydraulically connected with the reservoir. The geothermal system is the whole volume of rocks in which fluids move, both inside and outside the reservoir, together with the heat source and natural discharge features. These are often classified based on reservoir temperatures (Hochstein, 1990) as:

- $\quad<125^{\circ} \mathrm{C}$ : low-temperature geothermal systems

- $\quad 125-225^{\circ} \mathrm{C}$ : intermediate-temperature geothermal systems

- $\quad>225^{\circ} \mathrm{C}$ : high-temperature geothermal systems 
A geothermal resource is a volume of rock where heat can be economically harnessed for conversion to electricity or direct heat utilisation. Heat is mined from liquid and vapour circulating in pores and fractures in the rock or directly from the rock itself. The geothermal system being the natural entity, and the geothermal field being the geothermal resource and the infrastructure and land boundaries associated with the geothermal power station.

A geothermal system can be described as convecting water in the upper crust of the Earth, which, in a confined space, transfers heat from a heat source to a heat sink, usually the free surface (Hochstein, 1990) and is made up of three components:

\section{- Geothermal heat source}

The heat source can be either a localised source of heat associated with shallow-level magmatic intrusions, that yields heat fluxes above the ambient gradient for some time or, as in low-temperature systems, the Earth's normal temperature, which, as explained earlier, increases with depth (Dickson and Fanelli, 2004). Systems that best support energy development are where magmatic intrusions are emplaced high in the crust, and induce convective circulation of groundwater. Multiple intrusions (composition depends on geological setting) are most favourable for large, long lived hydrothermal systems. These intrusions typically reach depths of $2-10 \mathrm{~km}$ but are most beneficial for the hydrothermal system when at $\sim 2-5 \mathrm{~km}$ (brittle (fractured) versus plastic regime) (Mock et al., 1997). Examples of geothermal systems where intrusions and plutons lie within drilled depths are Ngatamariki (New Zealand; Arehart et al., 2002) and Geysers (USA; Dalrymple et al., 1999). In some areas with little recent magmatism, crustal thinning due to active extension, high heat flow and deeply penetrating faults systems allow for deep circulation of meteoric waters and subsequent heating to develop geothermal systems (i.e. Great Basin, western USA (Faulds et al., 2011) and the Aegean extensional province, western Turkey (Faulds et al., 2010)).

\section{- Host (reservoir) rocks}

These can be of any lithology, but given that systems often form in volcanic areas, the reservoir rocks are often volcanic or volcanogenic. It is not uncommon for an old sedimentary/metamorphic basement to be present at depth, though this often has a low-permeability, which may not be favourable for production. There can also be present a younger sedimentary cover, which can act as shallow aquitards and separate aquifers. Geothermal systems in the TVZ are typical of the situation where a volcanic/volcanogenic sequence overlies basement rock, in this case greywacke (e.g. 
Ohaaki and Kawerau; Wood et al., 2001), though in some of the geothermal systems (i.e. Wairakei) geothermal drilling has yet to reach the basement. In hydrothermal systems associated with composite volcanoes, the local basement may not be reached. In some cases (i.e. Lihir, Papua New Guinea; White et al., 2010), the geothermal drilling intersects complex cross cutting intrusive complexes at depth.

\section{- Hydrothermal fluid and its chemistry}

The fluid at the depth of economic exploitation is mainly meteoric water, though it can include a percentage of magmatic water (fluid that has evolved through chemical and isotope equilibrium with a silicate melt, regardless of the previous history of its component water; Henley and Ellis, 1983) and volatiles. In places seawater can be a fluid source, which makes the chemistry of the system more complex (i.e. Reykjanes and Svartsengi, Iceland; Arnorsson, 1978). The fluid circulating through most systems is a near-neutral-pH dilute brine ( $\sim 1 / 10$ salinity of seawater), with a content of dissolved gases. At depth, the fluids have a strong magmatic influence, with high gas content $\left(\mathrm{HCl}, \mathrm{SO}_{2}\right)$, while at typical production level they are mainly meteoric, with more dilute gases $\left(\mathrm{CO}_{2}\right.$ (most important) and $\mathrm{H}_{2} \mathrm{~S}$; Dickson and Fanelli, 2004).

Pressure and temperature profiles change within geothermal systems (Fig. 1.1). Pressures in the fluid phase are lithostatic near the magmatic intrusion due to limited permeability $(\sim 2.5 \mathrm{bar} / 10 \mathrm{~m})$, whereas at shallower depths in the system, pressures are hydrostatic ( $\sim 1$ bar/10 m) (KML, 1995). In low permeability zones in the system, the temperature profile is conductive and usually linear, whereas in high permeability zones (i.e. in the main upflow), the profile follows the boiling-point-for-depth curve (Grant and Bixley, 2011). Temperatures change most rapidly near the surface, and may become almost isothermal at depth (Grant and Bixley, 2011). The temperature and pressure differentials cause development of a large convective cell, with a central upflow zone, and corresponding downflow or inflow zone of recharge fluid (Fig. 1.1). Boiling within geothermal systems can be caused by a reduction in pressure and/or an increase in temperature and is promoted by high gas content (Christenson, 1997). 

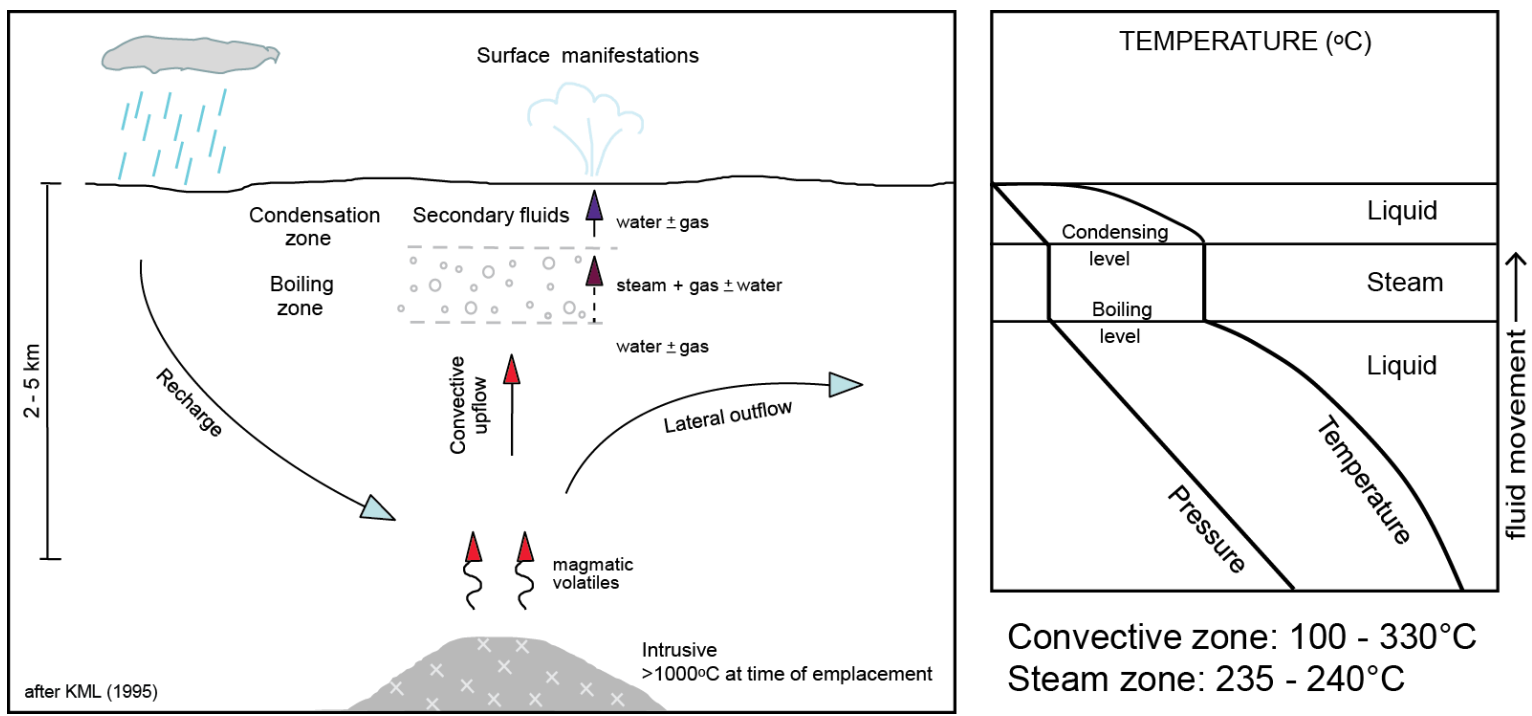

Figure 1.1 Schematic representation of an ideal geothermal system (after KML, 1995).

\section{$1.3 \quad$ TYPES OF GEOTHERMAL SYSTEM}

A number of factors lead to the development of a number of different types of hydrothermal systems. The main factors considered here are fluid chemistry, rock chemistry and hydrology of the system. The latter is directly affected by the local relief and elevation, which controls the meteoric recharge and piezometric surface of the reservoir.

Major hydrologic types include the following, and are described in more detail in Fig. 1.2:

- Continental

- Near-continental island-arc

- Continental margin/cordilleran

- Ocean island arc

- $\quad$ Submarine (not considered here) 


\begin{tabular}{|l|l|} 
Continental type \\
(e.g. Wairakei, New Zealand)
\end{tabular}

Figure 1.2 Schematic models and descriptions of the main types of geothermal systems (after Giggenbach, 1981; Henley and Ellis, 1983).

\subsection{NEW ZEALAND'S GEOTHERMAL SYSTEMS}

Geothermal systems occur in many parts of New Zealand, with many continental-type hightemperature systems located in the TVZ (Fig. 1.3) and at Ngawha in Northland. Moderate- to very low-temperature systems are widely scattered through the country, with some associated with areas of young volcanism (Northland, Hauraki Plains, and coastal Bay of Plenty: Reyes et al., 2010) while other hot springs are associated with faults and tectonic features (common in the South Island: Reyes et al., 2010).

Through the TVZ, geothermal systems are associated with young and active rhyolitic volcanism. Magma is intruded into the stretched and fractured crust in the actively rifting TVZ, resulting in temperatures of at least $350{ }^{\circ} \mathrm{C}$ at depths of less than $5 \mathrm{~km}$. This has provided a large heat source from which geothermal systems have developed. Many of the high-temperature geothermal systems have been delineated by geophysics and/or drilling (Fig. 1.3).

Of New Zealand's 129 identified geothermal areas, fourteen are in the $70-140{ }^{\circ} \mathrm{C}$ range, seven in the $140-220{ }^{\circ} \mathrm{C}$ range, fifteen in the $>220{ }^{\circ} \mathrm{C}$ range and the remainder $<70{ }^{\circ} \mathrm{C}$ (NZGA, 2013). Individual fields are typically about $12 \mathrm{~km}^{2}$ in area and spaced $15 \mathrm{~km}$ apart (Kissling and Weir, 2005), and include all those in New Zealand that discharge boiling water. The Kawerau geothermal system is one of the high-temperature systems in the $>220{ }^{\circ} \mathrm{C}$ 
range, and is the focus of study for this thesis.

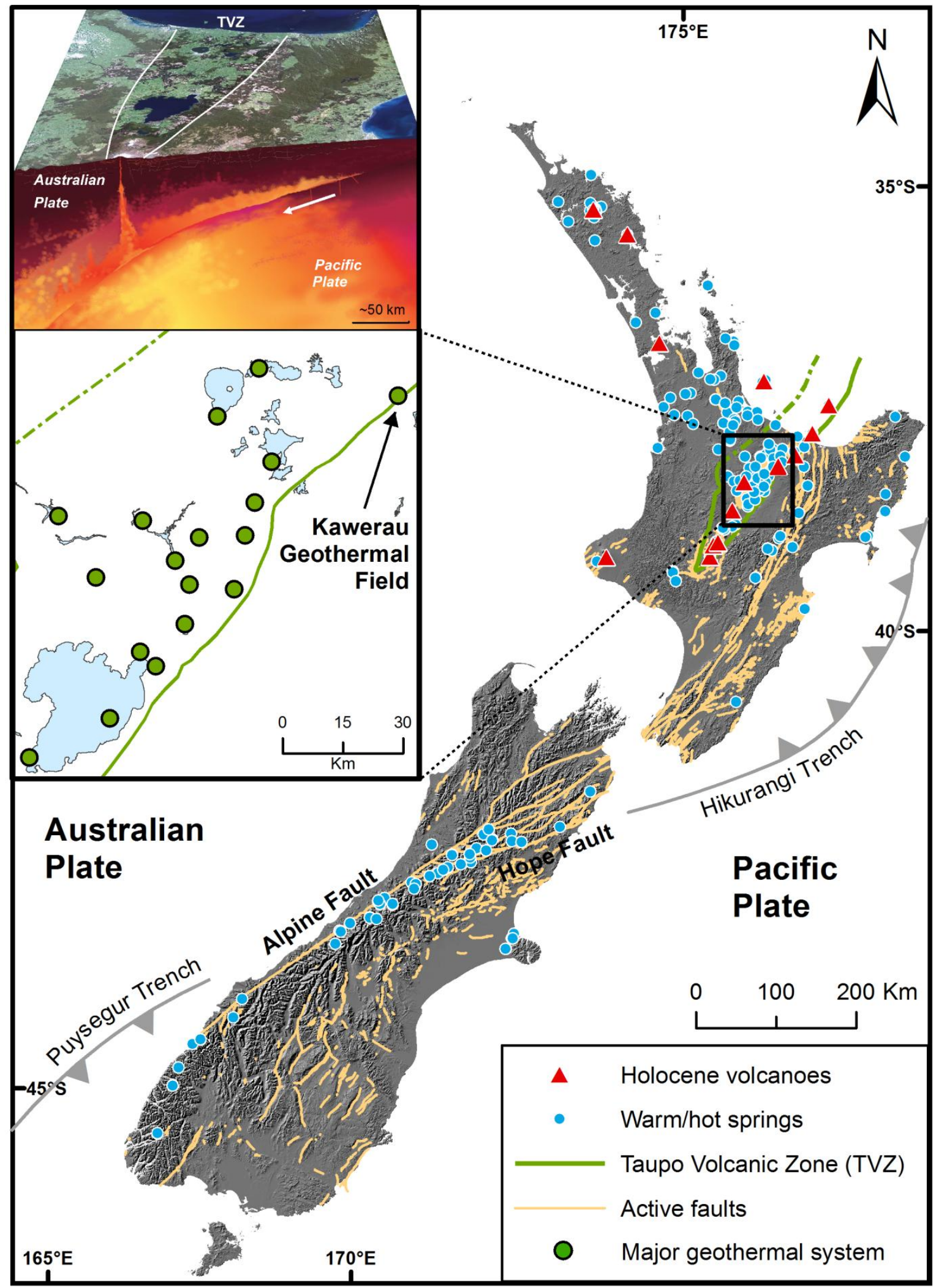

Figure 1.3 Distribution of thermal springs, active volcanoes and the main active fault zones in New Zealand (hot spring locations from Mongillo and Clelland (1984) and Reyes et al. (2010); active faults from GNS Science (2013). Major high-temperature systems indicated are those that have been delineated by geophysics and/or drilling. 


\subsection{KAWERAU GEOTHERMAL SYSTEM}

The Kawerau Geothermal Field is located $\sim 15 \mathrm{~km}$ inland from the Bay of Plenty coastline, immediately east of Kawerau township. It is the most north-easterly of the major, hightemperature geothermal systems located in the Taupo Volcanic Zone (TVZ) (Fig. 1.3), located close to the flanks of the late Quaternary andesitic/dacitic Putauaki (Mt. Edgecumbe) volcano and the rhyodacite domes that form the Onepu Hills (Nairn, 2002). The Tarawera River runs through the centre of the field, with its flood deposits forming much of the surficial geology. The surface features of the geothermal system have been in a natural state of decline prior to development, with most of the surface thermal manifestation focussed on the Onepu and Rotoitipaku-Umupokapoka areas.

\subsubsection{Regional geological setting}

The TVZ (Fig 1.4) is a north-northeast to south-southwest trending rifted arc (Wilson et al., 1995a) or back-arc rift (Cole et al., 1995) produced as a result of oblique subduction of the Pacific Plate beneath the Australian Plate. Onshore, the TVZ extends from the Tongariro Volcanic Centre to the Bay of Plenty coast, and is the focus of Quaternary volcanic activity. Tectonism within the TVZ is dominated by laterally discontinuous, northeast-striking normal faults (Cole, 1984). These faults usually have an en-echelon arrangement, and are largely restricted to a $15-20 \mathrm{~km}$ wide zone of intense faulting which defines the Taupo Rift (Nicol et al., 2006; Villamor and Berryman, 2006). Immediately east of the TVZ is a zone of major strike-slip faults, the North Island Shear Belt (Fig. 1.4; NISB), which extends the length of the North Island, to intersect and converge with the TVZ at its northern end. Many of these faults are active (Berryman and Beanland, 1988; Mouslopoulou et al., 2007). Offshore, the faulting related structure comprises a series of parallel basement ridges and basins which are aligned northeast-southwest. These basement structures are generally $50 \mathrm{~km}$ long and $10-15$ $\mathrm{km}$ wide, bounded by normal faults (Wright, 1992; Lamarche et al., 2006). 


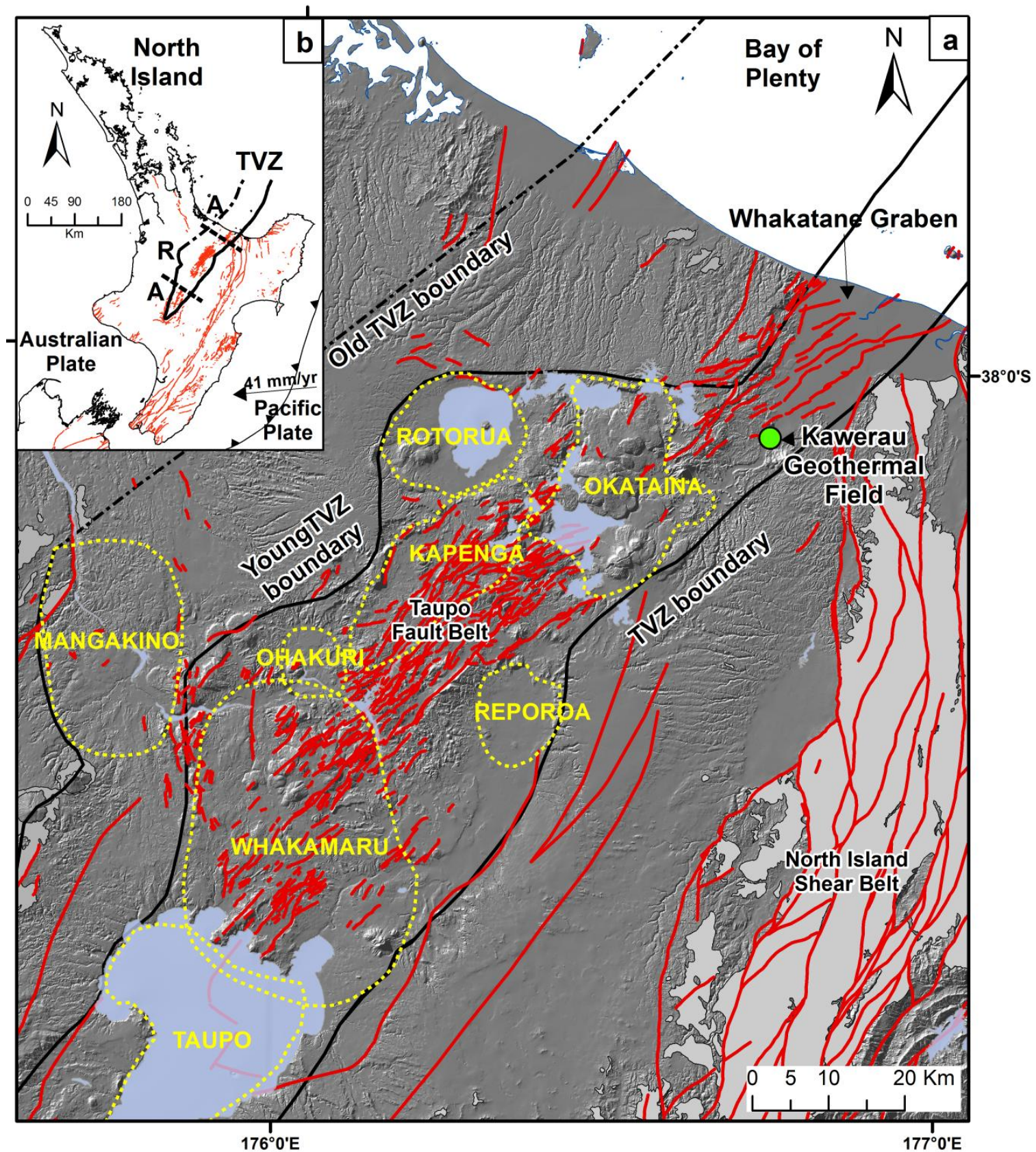

Figure $1.4 \quad$ a) Map of structural boundaries of calderas in central Taupo Volcanic Zone (TVZ; modified from Wilson et al. (1995a) and Gravley et al. (2007)). Regions of outcropping Mesozoic greywacke are indicated in grey. Mapped faults are indicated in red (GNS Science, 2013); b) (inset map) the tectonic setting of the North Island of New Zealand where the Pacific Plate is being obliquely subducted beneath the Australian Plate. The North Island Shear Belt (NISB) is indicated and the division of TVZ into segments dominated by andesite-dacite (A) and rhyolite (R) volcanism is indicated (Wilson et al., 1995a). Active faults are indicated in red (GNS Science, 2013).

The history of the TVZ can be broadly divided into the 'old TVZ' from 2.0 Ma to 0.34 Ma, and 'young TVZ' from 0.34 Ma onwards, separated by the Whakamaru-group of eruptions. Deposits from these large eruptions obscure much of the evidence for older activity within the TVZ. There is segmentation along the TVZ into northeast and southwest andesite-dominated extremities with composite cones and no calderas, and a central $125 \mathrm{~km}$ long rhyolitedominated segment with eight identified caldera volcanoes (Wilson et al., 2009). Between 0.9 and $0.34 \mathrm{Ma}$, a major episode of uplift affected areas around the TVZ, while at the same time 
the main focus of activity may have migrated eastwards within the TVZ accompanying rifting along the axis of the zone (Wilson et al., 1995a).

The Kawerau Geothermal Field is located in the northern TVZ, towards its eastern boundary. The geothermal activity is at the southern end of the northeast-trending Whakatane Graben (Fig. 1.4), in a zone where the northeast-striking active rift of the TVZ intersects the northstriking strike-slip faults of the NISB (Nairn and Beanland, 1989; Mouslopoulou et al., 2007). This graben structure is evidently expressed just to the east of the Kawerau Field, where the 322 ka Matahina ignimbrite (Bailey and Carr, 1994; Leonard et al., 2010) is exposed, but occurs 10 to $420 \mathrm{~m}$ beneath the ground surface in the field itself.

During the last one million years, Mesozoic basement greywacke within the Whakatane Graben has been downfaulted to $1-2 \mathrm{~km}$ below sea level, with the resulting structural depression infilled by Quaternary volcanic rocks and sediments, almost entirely deposited under subaerial conditions. The Okataina Volcanic Centre (OVC) has been the main source of young ( $\leq 322 \mathrm{ka}$ ) volcanic activity to affect the Kawerau Geothermal Field area (Nairn and Beanland, 1989; Leonard et al., 2010). In particular, in Holocene times the andesitic/dacitic composite cone of Putauaki volcano (Mt Edgecumbe) has been constructed to the east of the field (Duncan, 1970; Nairn, 2002).

The Whakatane Graben (Fig. 1.4) is an area of active extension and faulting, with GPS geodetic measurements indicating an extension rate across the Whakatane Graben of 15 - 20 $\mathrm{mm} / \mathrm{yr}$ (Wallace et al., 2004). The most recent expression of surface faulting in the area was the 1987 Edgecumbe Earthquake, which was accompanied by $\sim 1 \mathrm{~m}$ of horizontal extension and subsidence (Nairn and Beanland, 1989). At the Kawerau Geothermal Field this was accompanied by $\sim 0.3 \mathrm{~m}$ of subsidence, although no fault ruptures occurred in the vicinity of the geothermal production area (Berryman and Beanland, 1988). Previously, the area northeast of the OVC was thought to have few active faults, although some faults were inferred west and north of Kawerau, within the Whakatane Graben. High-quality Light Detection and Ranging (lidar) data collected across the Rangitaiki Plains (Begg and Mouslopoulou, 2010) revealed new active fault traces that have ruptured the ground surface in the fastest extending part of the rift during the last $\sim 6.5 \mathrm{kyr}$. The surface expression of these faults has, however, been concealed or greatly reduced by the rapid volcaniclastic sedimentation associated with recent eruptions of Okataina and Taupo (Hodgson and Nairn, 2004, 2005; Manville et al., 2005). 


\subsubsection{Kawerau Geothermal Field}

Geothermal development in the area was initiated by Tasman Pulp and Paper Company (now Norske Skog Tasman) after successful scientific surveys and shallow drilling in 1951/52 by the Department of Scientific and Industrial Research and Ministry of Works. By 1957 seventeen wells (Fig. 1.5) had been drilled to supply geothermal steam to the Tasman pulp and paper processing plant, with the system fully operational in 1961. In the late 1950s four of the wells were deepened following a decline in field production and further drilling commenced in 1966 after continued field decline. The geothermal steam over this time was used for process heat, with excess steam used for up to $8 \mathrm{MW}$ of electrical generation (Blackwood and Carter, 1980).

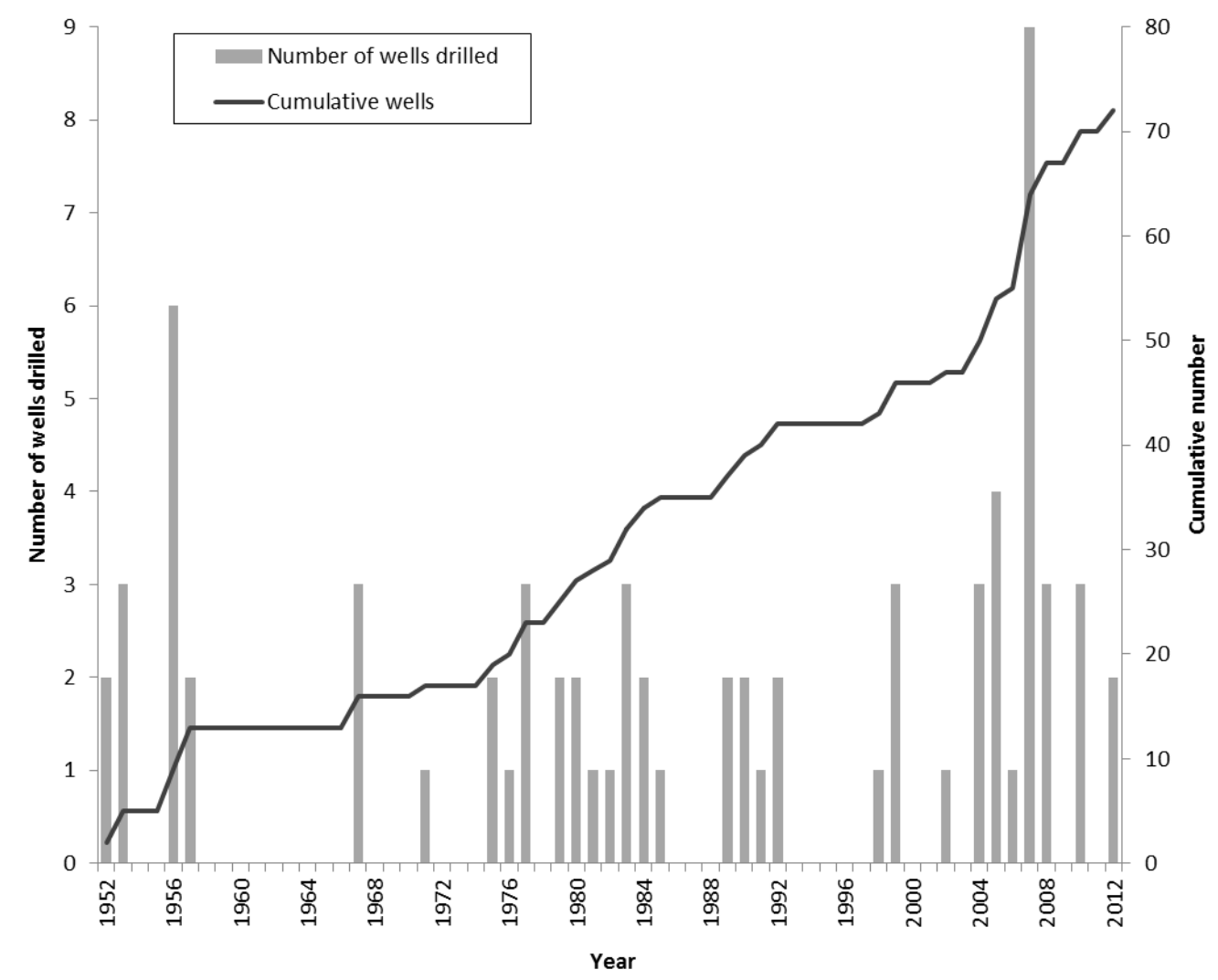

Figure 1.5 Number of wells drilled per year at Kawerau from 1952 to 2012 (dates of well drilling from MRP, 2013).

More than 70 wells (Fig. 1.6) have now been drilled in the field for various purposes, although no more than $6-7$ have been in production at any one time, with many of the older wells now used as monitor wells. Production from the older wells is mostly from around $1 \mathrm{~km}$ depth, while the more recent wells produce from depths greater than this in the greywacke basement. Downhole temperatures recorded in the field range from 250 to $310^{\circ} \mathrm{C}$ and fluids are reinjected at 115 to $120{ }^{\circ} \mathrm{C}$, although most water from the field is discharged into the Tarawera River after passing through a cooling channel. A total available resource greater than 350 MW electrical output (MWe) has been estimated (Lawless, 2002). 
Around 270 tonnes per hour of steam is provided to the Norske Skog Tasman mill where it is used for process heat, electricity generation and timber drying. In addition, Bay of Plenty Energy operate two binary plants rated at a total of 6 MWe which use some of the separated geothermal water as a heat source and generate about $34 \mathrm{GWh} /$ year. These plants are linked to separator plants physically situated on either side of the Tarawera River. In 2004, Norske Skog Tasman replaced their existing geothermal turbo-alternator with a refurbished ex-US Navy 8 MWe turbo-alternator which generates about 43 GWh/year. Mighty River Power Ltd. (MRP) has undertaken an exploration programme in a new area of the Kawerau Field, which has resulted in a 100 MWe power station being commissioned in August 2008. An independent 8.3 MWe binary cycle plant based on the production from well KA24 was also commissioned in September 2008.

Until 2005 the geothermal resource at Kawerau was owned by the New Zealand Government (the Crown). In July 2005 the Crown negotiated a Treaty of Waitangi settlement with Ngati Tuwharetoa Ki Kawerau, a prominent local Maori tribe. This settlement resulted in a contemporaneous transaction taking place between the Crown, MRP and Ngati Tuwharetoa Settlement Trust (NTST), whereby the Crown transferred its Kawerau geothermal assets to MRP. MRP then on-sold the majority of the geothermal assets, including the Crown's direct heat business and steam supply agreements to NTST. The assets are managed by Ngati Tuwharetoa Geothermal Assets Limited (NTGA). Currently NTGA, Norske Skog Tasman and MRP are party to a Geothermal Steamfield Management Agreement.

\subsubsection{Surface hydrothermal features}

Surface features at Kawerau prior to development included hot springs, seepages, sinters, hydrothermal eruption vents, altered and steaming ground, and small fumaroles (Studt, 1958; Mongillo, 1998). Many of the features were focussed in the Onepu thermal area (Fig. 1.6), with springs and seepages concentrated along the banks of the Tarawera River and around the southern shore of Lake Rotoitipaku. Steaming ground occurred on the hills $1-2 \mathrm{~km}$ southwest of Onepu (Onepu thermal area; Fig. 1.6), and on the west side of Kawerau township (Ruruanga thermal area; Fig. 1.6). Also described by Studt (1958) were gas emissions in swamp lands to the east of the field, marked as the "boiling lake" on some maps. 


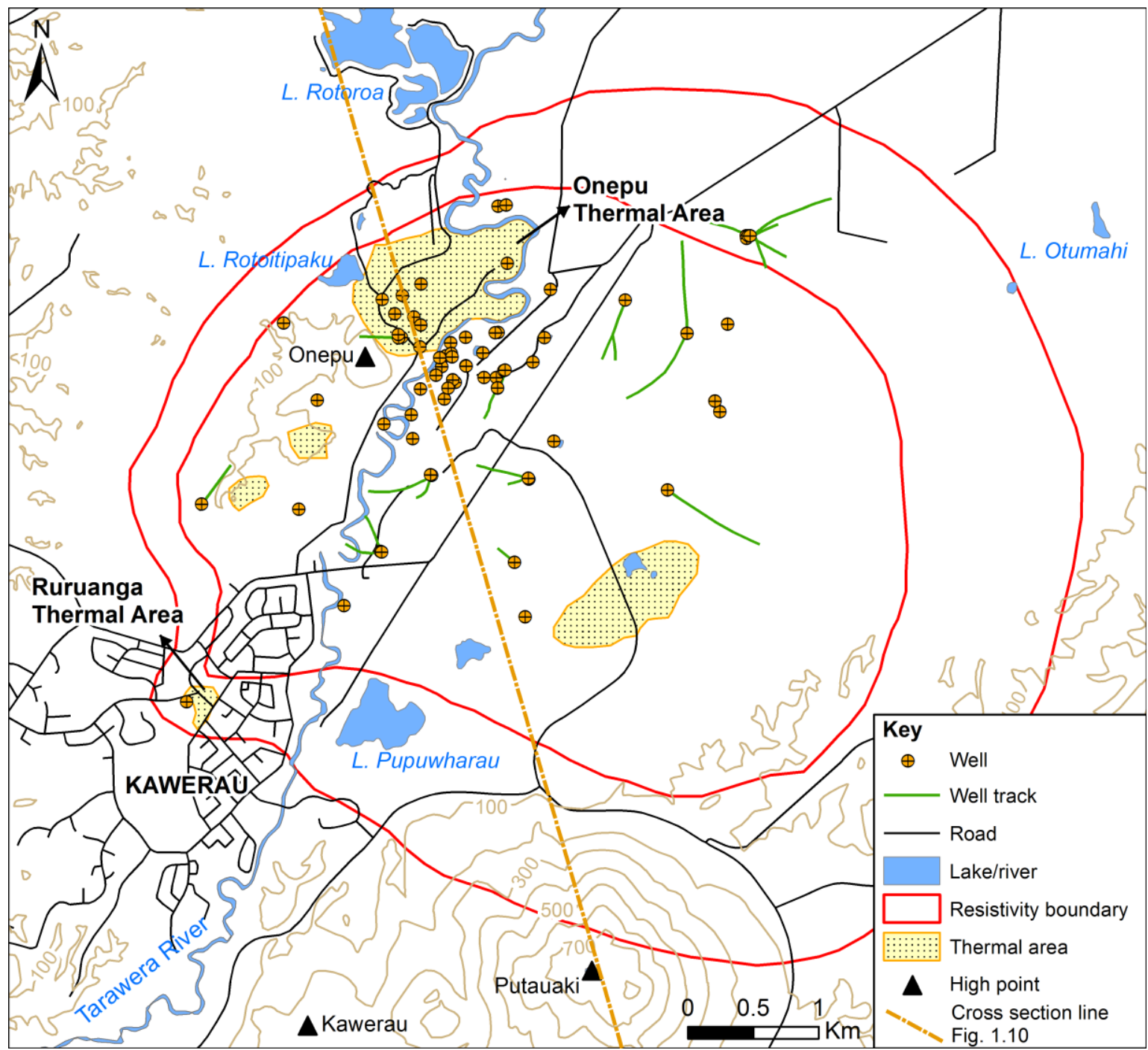

Figure 1.6 Locations of the main thermal areas, geothermal wells, and the resistivity boundary zone of the Kawerau Geothermal Field at about $500 \mathrm{~m}$ depth (bracketed by the 20 and $50 \Omega \mathrm{m}$ resistivity contours; after Allis, 1997).

From interpretation of early chemical and physical data and hydrothermal feature descriptions, the thermal activity suffered serious decline during the first half of the 1900's, prior to exploitation of the geothermal resource. This initial decline was due in part to the downcutting by the Tarawera River, possibly associated with incision following a break-out flood from Lake Tarawera in 1904 (White et al., 1997; Hodgson and Nairn, 2005). Analysis of data from the period of exploitation, including chemical and physical measurements, hydrothermal feature descriptions, aerial photographs and thermal infrared imagery, show that the surface activity had continued to decline significantly to 1996 (Mongillo, 1998). The chemical and physical data and descriptions for the thermal features will not be addressed in this summary, but details can be found in published and unpublished reports and papers by Anonymous (1904, 1922), Herbert (1921), Grange (1937), MacPherson (1944), Studt (1958), Mahon (1962a,b), Banwell (1962), Dickinson (1973), Christenson (1986), Lumb (1992), Mongillo and Bromley (1992), Allis et al. (1993),Allis (1997) and Mongillo, 1998. 
Allis et al. (1995) suggested that the natural heat and mass flow from the Kawerau geothermal system provide an indicator of the minimum size of the system. There is significant uncertainty in the past level of heat and mass flow, however, as spring activity has changed over the last century or more, due to natural and man-made causes. The former Lake Umupokapoka is an example, described in 1904 as a hot lakelet with a large overflowing spring with a discharge of $2725 \mathrm{~m}^{3}$ /day (Anonymous, 1904). By 1944 this discharge was a daily output of $1400 \mathrm{~m}^{3}$ /day and the Umupokapoka hot spring could not be identified (MacPherson, 1944). By 1952, it had become a sintered lakebed with numerous bubbling hot pools and little overflow (Studt, 1958). Studt (1958) attributed this decline to downcutting of the Tarawera River (by $3 \mathrm{~m}$ between 1920 and 1950), and the resultant lowering of the groundwater table.

The only detailed survey of heat flow at Kawerau was carried out by in 1952 by Studt (1958). Since this time, the main hot spring area adjacent to the Onepu thermal area has been covered by sludge waste from the Tasman mill, rendering the features inaccessible. Allis (1997) indicated that the most active thermal areas in 1952 were around the southern rim of Lake Rotoitipaku (Fig. 1.6) and the northern margin of the former Umupokapoka, with the total outflow being $778 \mathrm{~m}^{3} /$ day. The total heat flow from the Onepu thermal area was estimated to be 100 MW (thermal) (Studt, 1958), which included 70 MW from seeps to the Tarawera River and $>10$ MW evaporative loss from Lake Rotoitipaku. This $100 \mathrm{MW}$ heat flow estimate did not, however, include heat output from steaming ground south of the Onepu thermal area and natural outflow (to the north of the field) which does not reach the ground surface (Bignall and Harvey, 2005). Allis (1997) and Bignall and Harvey (2005) commented that an increase in chloride concentration with depth shows that mixing with cross-flowing groundwater as the geothermal fluids rise to the surface is an important process within the Kawerau system. The shallow waters have an enthalpy of $600 \mathrm{~kJ} / \mathrm{kg}$ (i.e. equivalent to $\sim 150{ }^{\circ} \mathrm{C}$ ), which amounts to an output of $\sim 19867 \mathrm{~m}^{3} /$ day. Heat output is dominated by seepage to the river, with a change in outflow above the river compensated by a change in the seepage to the river. The $70 \mathrm{MW}$ heat output estimated by Studt (1958) amounts to $\sim 22,000 \mathrm{~m}^{3} /$ day of $100{ }^{\circ} \mathrm{C}$ water, which is $<10$ times the original outflow of Umupokapoka (MacPherson, 1944; Allis et al., 1993; Allis, 1997; Bignall and Harvey, 2005).

In 1990, the rate of extraction was $\sim 300 \mathrm{~kg} / \mathrm{s}$, with the waste water mostly being discharged to the river. This would have caused drawdown of fluid pressures in the geothermal field. Pressure measurements at productions depth suggest a long-term drawdown of $<1$ bar (Bignall and Harvey, 2005). As the natural state has a pressure gradient in excess of hydrostatic, the decline in pressure in the near-surface aquifer feeding the hot springs was 
small. No long term monitoring of groundwater levels at that time was undertaken, although hot thermal seeps into the Tarawera River (adjacent to the Umupokapoka lakelet) still present at 17 mRSL in 1996 provide an upper limit for the extent of shallow drawdown, as the Umupokapoka sinter has a maximum elevation of 23 mRSL. Approximately half of the $6 \mathrm{~m}$ drawdown can be attributed to downcutting by the Tarawera River, with the other half being accounted for by geothermal production (Allis, 1997; Bignall and Harvey, 2005).

Apart from the seepages into the Tarawera River, described above, most of the features at Kawerau are no longer discharging. Given that sludge waste from the Tasman mill covers much of the original hot spring area at Lake Rotoitipaku, the current state is difficult to determine, though Christenson (1987) suggested that the small discharges still continued in the late 1980s. Analysis of data from the period of exploitation, including chemical and physical measurements, hydrothermal feature descriptions, aerial photographs and thermal infrared imagery, show that the surface activity has continued to decline significantly to present. Nearly all hot springs and pools stopped flowing in the period 1952 to 1988. Aerial photographs indicated that areas of bare ground and stressed vegetation decreased in size from 1945 to the present. Thermal infrared imagery from 1972 and 1992 provide evidence that these changes can be attributed to reduced surface temperatures (Mongillo and Bromley, 1992; Mongillo, 1998). Current thermal activity at Kawerau is dominated by feeble steam discharges associated with areas of barren, clay-altered ground and stunted vegetation growth. Notable exceptions to this are a hot spring (up to $89^{\circ} \mathrm{C}$ ) in the Parimahana Reserve/Ruruanga Stream area and the extensive seeps of high-temperature geothermal fluids that are discharging along the Tarawera River (Graham and Komischke, 2005).

\subsubsection{Subsurface extent of the field: geophysical evidence}

Surface activity at Kawerau is mostly concentrated in a $2 \mathrm{~km}^{2}$ area, although resistivity surveys reveal a more extensive geothermal reservoir at depth. Resistivity surveys utilise the contrast between the higher and lower resistivity characteristics of unaltered and hydrothermally altered rocks, respectively. High-temperature geothermal systems in New Zealand typically are delineated by a zone with relative change from lower to higher resistivity (Bibby, 1988; Bibby et al., 1995). The majority of measurements in the TVZ have been made using the Schlumberger array (spacing, AB/2 of $1000 \mathrm{~m}$ and $500 \mathrm{~m}$ ) described by Bibby (1988). For an array spacing of $500 \mathrm{~m}$ these measured resistivities can be regarded as weighted averages of the resistivity within the top $300 \mathrm{~m}$ depth $(600 \mathrm{~m}$ depth for the $1000 \mathrm{~m}$ array; Bibby et al., 1995). Early surveys in the area (1969 - 1970) were shallow penetrating, and indicated a 
resource area of $10 \mathrm{~km}^{2}$ at $\sim 250 \mathrm{~m}$ depth, centred on the site of the Tasman mill (Macdonald et al., 1970; Macdonald and Muffler, 1972). Surveys, from 1969 - 70 and extended in 1989, undertaken to greater depths have revealed that the geothermal resource is present over a greater area (Allis et al., 1995). The boundary zone of the Kawerau geothermal system is defined (Allis, 1997) by analysis of the transition from 'low' to 'high' apparent resistivity (bracketed by the 20 and $50 \Omega \mathrm{m}$ resistivity contours) with varying electrode spacing $(\mathrm{AB} / 2=$ $500 \mathrm{~m}$ and $1000 \mathrm{~m}$ ) (Fig. 1.7). This transition encompasses an area which varies between 19 and $35 \mathrm{~km}^{2}$, depending on whether the inner or outer edge of the boundary zone is included (Fig. 1.6). Variations in this boundary are either caused by one or more of: the presence of a low permeability zone separating the thermal and non-thermal waters, mixing between hot and cold waters, and/or the presence of a sloping boundary zone with depth (Allis et al., 1993, 1995; Allis, 1997; Bignall and Harvey, 2005).

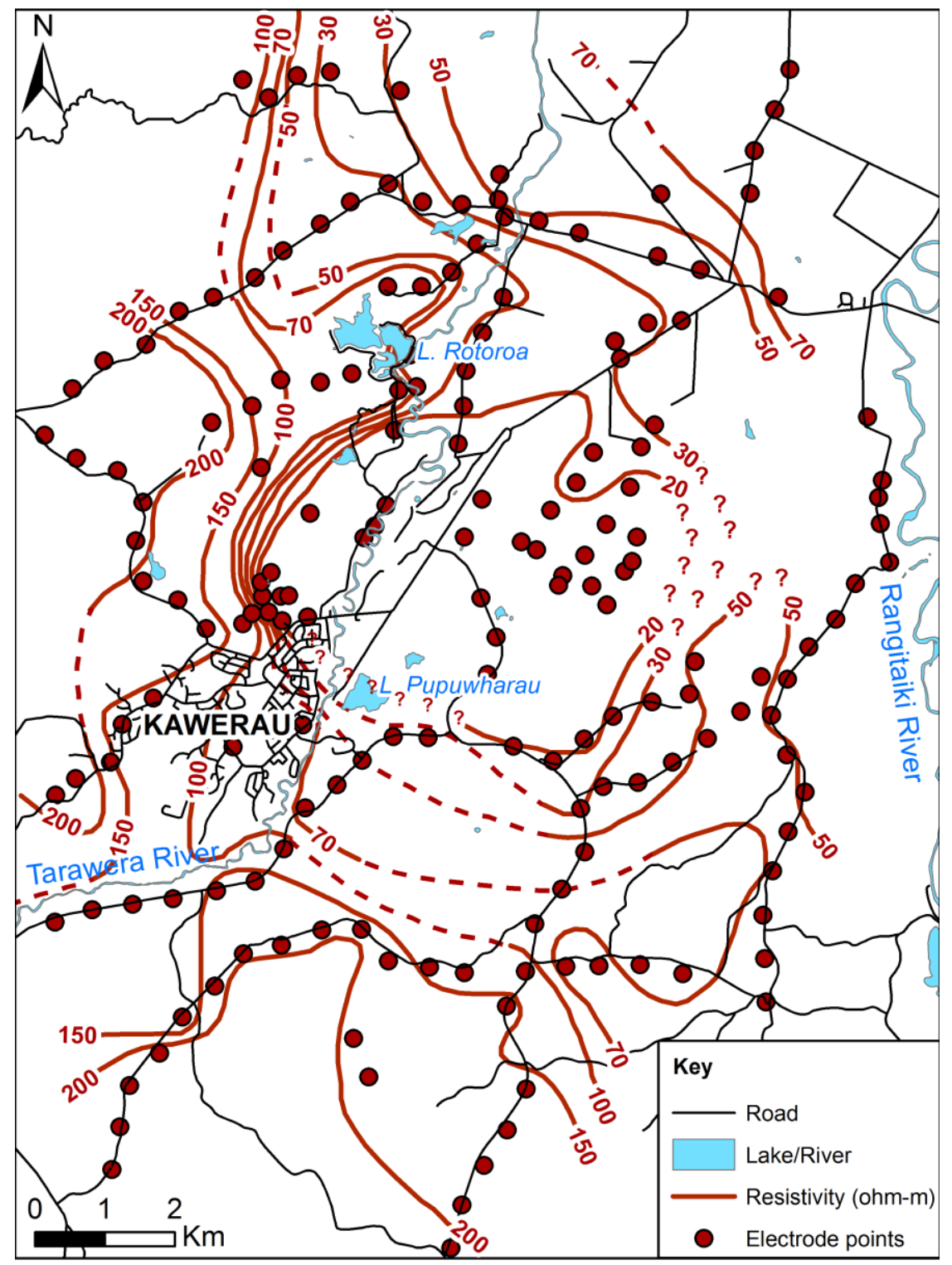

Figure 1.7 Contour of apparent resistivity (in $\Omega \mathrm{m}$ ) using Schlumberger electrode spacing AB/2=1000 m (nominal), from Allis (1997). Contours are dashed where data are in doubt or not available. 
Surveys have shown there to be a major eastward extension of the low resistivity region, to cover ground east of the mill and north of Putauaki volcano, with apparent resistivities $(A B / 2$ $=1000 \mathrm{~m}$ ) of $<20 \Omega \mathrm{m}$ for a distance of $>3 \mathrm{~km}$ to the east of the mill (Fig. 1.7). When the $\mathrm{AB} / 2=500 \mathrm{~m}$ and $\mathrm{AB} / 2=1000 \mathrm{~m}$ data are compared, the apparent resistivity decreases with depth. This inference suggests that hot geothermal fluids may exist at depths $>600 \mathrm{~m}$, possibly representing a major addition to the currently proven geothermal resource. Low resistivity values to the north and northeast of the main thermal areas are consistent with a northward outflow of thermal fluids from the field. This conclusion is supported by measurements of anomalous temperatures, and chloride and boron concentrations in groundwater wells situated 5 to $10 \mathrm{~km}$ north of the field (Allis et al., 1993, 1995; Allis, 1997; Bignall, 2005). Summaries of geophysical surveys at Kawerau can be found in Studt (1952), Macdonald and Muffler (1970) and Macdonald et al. (1972).

\subsubsection{Kawerau geology}

The modern geological landscape at Kawerau is dominated by Putauaki (Mt. Edgecumbe), a Holocene, multiple vent andesite-dacite volcano (Fig. 1.8), located near the southern boundary of the Kawerau Geothermal Field (Duncan, 1970; Nairn, 2002). Its eruptive activity is bracketed by ${ }^{14} \mathrm{C}$ ages of 9,500 cal. years B.P. on an underlying regional rhyolite fall deposit (Rotoma tephra: Lowe et al., 2013) and 3,400 cal. years B.P. on late-stage block-avalanche deposits (Carroll et al., 1997). Two main eruptive episodes have been recognised: earlier dacitic lavas forming the base and western part of Putauaki, and the main cone growth of high- $\mathrm{SiO}_{2}$ andesite lavas (Nairn, 1995). A small satellite cryptodome on the northeastern flank of Putauaki has intruded into and altered the overlying Matahina ignimbrite (Bailey and Carr, 1994). The 322 ka Matahina ignimbrite (Bailey and Carr, 1994; Leonard et al., 2010) is exposed to the southeast of the Kawerau Geothermal Field and is intersected by many drillholes in the field (see Chapter 3).

Hydrothermal eruption breccias are present on the eastern margin of the Kawerau Geothermal Field, interbedded with ${ }^{14} \mathrm{C}$-dated pyroclastic sequences and exposed in forestry road cuttings. The lower eruption breccia (Fig. 1.8) is bracketed by the Rerewhaakaitu tephra $(17,400$ cal. years B.P) and Rotorua tephra (15,700 cal. years B.P) while the upper eruption breccia rests on the Rotoma tephra (9,500 cal. years B.P) and is covered by the Mamaku tephra (8,000 cal. years B.P) (Nairn and Wiradiradja, 1980; Lowe et al., 2013). At least 7 eruption centres have been identified (Christenson, 1987). Shallow depressions, some with stagnant pools and including Lake Pupuwharau and the hydrothermal feature once known as 
Boiling Lake, are also likely related to hydrothermal eruptions (Christenson, 1987). The breccias indicate high temperatures in the source area at the time of the eruptions, although shallow drillhole temperatures in these areas are now cool. Nairn (1986) suggests that this cooling is due to the growth of the Putauaki cone, increasing the hydrostatic head and causing more, cool meteoric water to flow into the system.

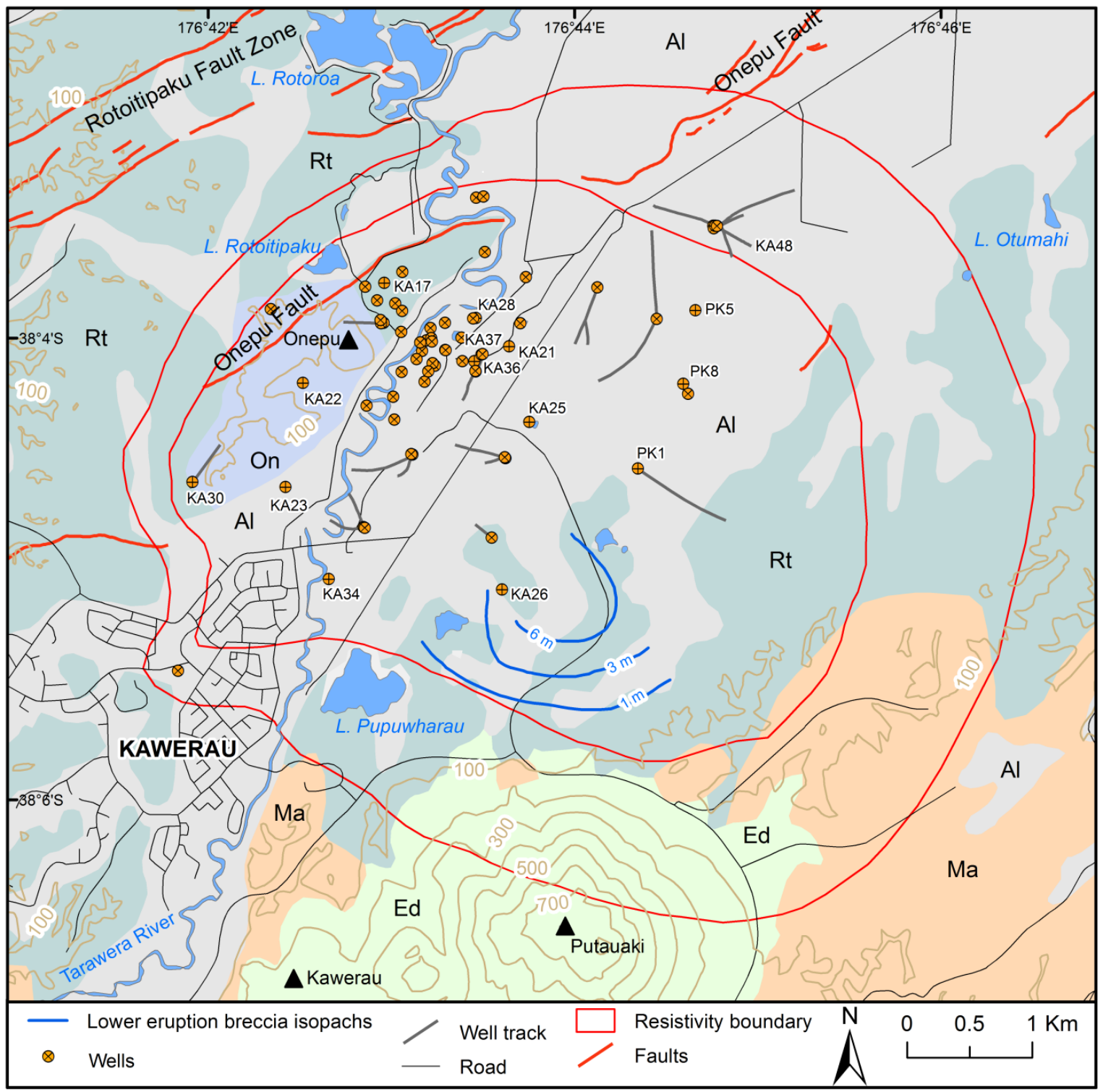

Figure 1.8 Map of Kawerau Geothermal Field showing drillholes, active faults (GNS Science, 2013), lower eruption breccia isopachs (Nairn and Wiradiradja, 1980) and approximate resistivity boundary zone at about $500 \mathrm{~m}$ depth (after Allis, 1997). Key to geology map units (after Leonard et al., 2010): Ma - Matahina ignimbrite; Rt - Rotoiti and Mangaone ignimbrites; Al - volcaniclastic alluvial deposits from breakout floods down the Tarawera River (Hodgson and Nairn, 2005); Ed lavas of Putauaki volcano (Mount Edgecumbe: Nairn, 2002); On - Onepu rhyolite domes.

Other geological units exposed at the surface in the Kawerau area are young pyroclastic deposits and Holocene alluvial material deposited by the Tarawera River (Nairn, 1986; Nairn, 2002). Soil mapping by Pullar (1985) showed that sediments associated with the Whakatane (5.5 ka) Kaharoa (1314 \pm 12 AD) and Tarawera (1886 AD) eruption episodes form the main 
surficial units in the Whakatane Graben (see also Hodgson and Nairn, 2004, 2005). Largely due to the high influx of sediment deposited by floods that passed down the Tarawera River in 1904 (Hodgson and Nairn, 2004), there are no surface fault traces mapped within the western (drilled) part of the Kawerau Geothermal Field. The surface trace of the Onepu fault, which ruptured during the 1987 Edgecumbe Earthquake, was evident $1 \mathrm{~km}$ from the northwest margin of the field (Fig. 1.8). Many buried faults underlie the geothermal field, recognised in drillcore and as offsets in drillhole stratigraphy (Nairn, 1977, 1982, 1986; Grindley, 1986; Christenson, 1987; Allis et al., 1995; SKM, 2003; this thesis, Chapters 3 and 4).

The subsurface stratigraphy encountered during drilling at Kawerau has previously been differentiated based on descriptions by Nairn (1977, 1981, 1982, 1986), Grindley (1986), Christenson (1987) and Allis et al. (1995). The correlations in this work were primarily achieved by similarities in texture and mineralogy found under plane light microscopy and cuttings and core and petrographic examination of thin sections from these units. Much of the core and cuttings retrieved during drilling at Kawerau has been extensively hydrothermally altered, making some of the correlations somewhat tenuous.

\subsubsection{Hydrothermal alteration}

In geothermal areas, where hot geothermal fluids pass through permeable zones in the reservoir, primary minerals in the rocks react with the fluid to form hydrothermal minerals (Browne, 1970). The degree to which primary minerals have been replaced by hydrothermal minerals, and how much the primary rock textures are obscured by alteration of the clasts and/or groundmass, reflects the intensity of alteration (Table 1.1). The secondary (hydrothermal) minerals provide information about temperatures and permeability (e.g. adularia, suggested to be indicative of high permeability: Browne, 1970) in the reservoir and, potentially, how these conditions have changed over time. The minerals also reflect the chemistry of the fluids from which they have crystallised. Temperature stability ranges of some of the more common minerals are shown in Fig. 1.9. Generally, with increasing depth into the reservoir, hydrothermal alteration follows a progression of alteration assemblages described in Table 1.2. Overprinting of these assemblages can occur where there has been either heating or cooling events. 


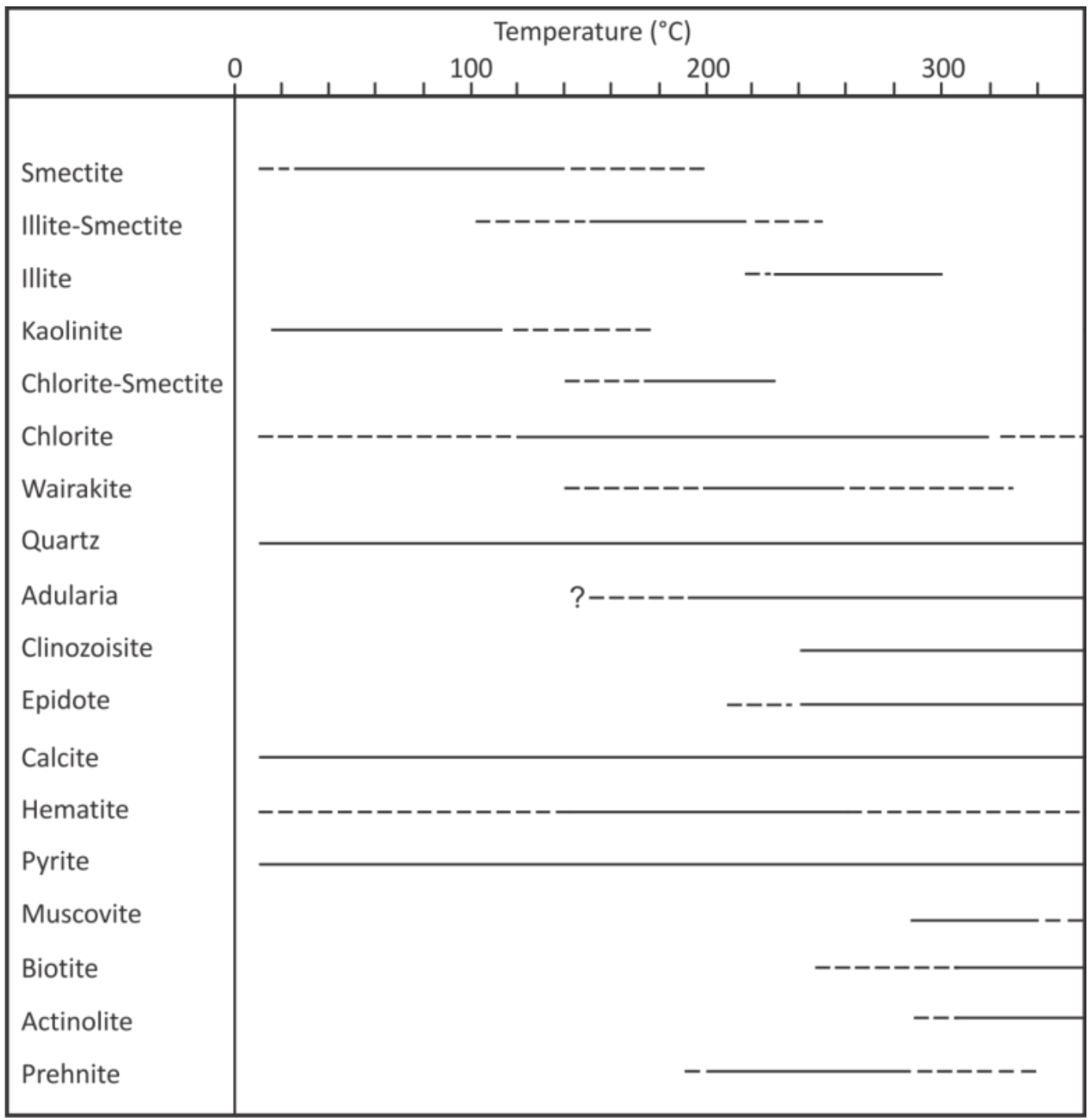

Figure 1.9 Temperature stabilities of common hydrothermal (secondary) minerals (after Henley and Ellis, 1983).

The hydrothermal minerals present in the Kawerau system are typically in equilibrium with the fluids from which they were deposited (Christenson, 1997). The shallow levels of the field have a $\sim 100 \mathrm{~m}$ thick zone of acid alteration. Near-surface deposits in this zone are typically unaltered, though they may have present deposition of minerals such as native sulphur, formed by condensation of $\mathrm{H}_{2} \mathrm{~S}$ bearing steam above a boiling zone (Nairn and Wiradiradja, 1980; Bignall, 2011). The low-temperature assemblage (e.g., halloysite, cristobalite, kaolinite, smectite, tridymite) extends typically to $>300 \mathrm{~m}$ depth, though locally deeper in some parts of the Kawerau Field (i.e. southeast). It is important to recognise this assemblage at greater depth, as it can indicate the presence of cool and possibly acidic inflows into the field. 
Table $1.1 \quad$ Hydrothermal alteration intensity (after Gifkins et al. 2005).

Intensity Description

\begin{tabular}{ll}
\hline Unaltered & Fresh rock; primary mineralogy and texture preserved (Note: unaltered rock can be weathered). \\
Weake & Texture and most primary mineralogy $(>75 \%)$ preserved; small patches of groundmass replaced with secondary minerals \\
Moderate & $\begin{array}{l}\text { Texture preserved; primary mineralogy partially }(25-75 \%) \text { replaced; generally ferromagnesian minerals and phyllosilicates } \\
\text { are replaced by secondary minerals but feldspars are preserved }\end{array}$ \\
Strong & Texture preserved; primary mineralogy completely replaced by secondary minerals \\
Intense / & $\begin{array}{l}\text { Texture completely obliterated and primary mineralogy completely replaced by secondary minerals (except for primary } \\
\text { quartz, zircon, and apatite) }\end{array}$
\end{tabular}

Table 1.2 Hydrothermal alteration assemblages and their associated minerals (after Guilbert and Park, 1986).

\begin{tabular}{|c|c|c|}
\hline Assemblage & Mineralogy & Fluid Conditions \\
\hline Advanced Argillic & $\begin{array}{l}\text { Alunite, diaspore, quartz, } \pm \text { pyrophyllite }\left(>300^{\circ} \mathrm{C}\right), \pm \\
\text { chalcedony, } \pm \text { kaolinite, } \pm \text { dickite, } \pm \text { anhydrite }\end{array}$ & $\begin{array}{l}\text { Acid-sulphate fluids formed from oxidised steam } \\
\text { condensates }\end{array}$ \\
\hline Intermediate Argillic & Kaolinite, smectite, and interlayered illite-smectite & $\begin{array}{l}\text { Low-T }\left(<250^{\circ} \mathrm{C}\right) \text {, acid to neutral } \mathrm{pH} \text { and low salinity } \\
\text { fluids }\end{array}$ \\
\hline Pbyllic & $\begin{array}{l}\text { Illite/sericite, quartz, pyrite } \pm \text { anhydrite } \pm \text { minor chlorite, } \\
\text { calcite, titanite and rutile }\end{array}$ & $\begin{array}{l}\text { Moderate- to high-T }\left(>200^{\circ} \mathrm{C}\right) \text {, acid to neutral fluids } \\
\text { at a range of salinity. Common in permeable zones } \\
\text { and adjacent to veins }\end{array}$ \\
\hline Propylitic & $\begin{array}{l}\text { Chlorite, illite/sericite, epidote, quartz, albite, calcite and } \\
\text { anhydrite }\end{array}$ & $\begin{array}{l}\text { High-T }\left(>200^{\circ} \mathrm{C}\right) \text {, near-neutral } \mathrm{pH} \text { fluids, commonly } \\
\text { in low permeability areas }\end{array}$ \\
\hline Potassic & $\begin{array}{l}\text { K-feldspar, biotite, quartz, magnetite, muscovite, } \pm \\
\text { anhydrite, } \pm \text { apatite, } \pm \text { sulphides }\end{array}$ & $\begin{array}{l}\text { High-T }\left(>300^{\circ} \mathrm{C}\right) \text {, near-neutral } \mathrm{pH} \text { fluids, close to or } \\
\text { within intrusions }\end{array}$ \\
\hline
\end{tabular}

With increasing depth, the alteration passes into a 'typical' neutral-pH hydrothermal assemblage (variously of epidote, quartz, calcite and illite, indicative of temperatures exceeding $\left.240{ }^{\circ} \mathrm{C}\right)$ : Bignall, 2011). For much of the volume of the field, the occurrence of these hightemperature minerals is consistent with measured well temperatures, and most of the producing wells at Kawerau are close to their boiling-point-for-depth condition. Locally, however, the alteration mineralogy is such that one can infer the presence of zones of cooling or heating. For example, in KA22 and KA29 there is epidote (indicative of temperatures of $>240{ }^{\circ} \mathrm{C}$ : Browne, 1970) present at depths where measured temperatures are currently lower than $240{ }^{\circ} \mathrm{C}$. As well as cooling, there are indications of heating, such as in the southeast part of the geothermal field.

Temperature and/or chemical changes within a geothermal reservoir may be indicated by the co-existence of non-equilibrium mineral assemblages. At Kawerau, 'neutral' and 'low $\mathrm{pH}$ ' mineral assemblages are reported together, or in close proximity, as in KA5, KA16, KA21 and KA25. Christenson (1987) described the occurrence of chalcedony and epidote in the same 
vein in KA10; the former is indicative of $<190{ }^{\circ} \mathrm{C}$ fluid conditions whereas the latter first appears in Kawerau wells where downhole temperatures are $250-290{ }^{\circ} \mathrm{C}$.

The history of these changes can in part be examined by looking at changes in temperature and chemistry reflected in the fluid inclusion trapped in the hydrothermal minerals and the stable isotopes of the minerals themselves. Christenson (1987) did detailed work in this regard and an extension of this using more recently drilled wells is presented in Chapter 5 . In that chapter, I also relate these changes in fluid chemistry and temperature to the emplacement of heat sources (localised magma bodies) over time.

\subsubsection{Conceptual model of the Kawerau Geothermal Field}

Conceptual models of geothermal systems are based on analysis of geological and geophysical information, temperature and pressure data, information on reservoir properties as well as information on the chemical content of reservoir fluids (Axelsson, 2013). The models are used to aid in targeting drillholes and should be revised throughout the exploration, development and utilisation of a geothermal system as more data become available.

The conceptual model of the Kawerau Geothermal Field presented in Bignall and Harvey (2005) and Bignall and Milicich (2012) indicates deep hot water moving upwards through basement greywacke via widely spaced, steeply dipping, northeast-striking normal faults (and cross-cutting northwest-striking faults) and/or fractures of high local permeability, within otherwise largely impermeable rock. Faults and fractures in the basement greywacke pass into overlying units, where hot water spreads laterally into permeable zones along subhorizontal volcanic and sedimentary layers. The highest measured well temperatures occur towards the southern part of the geothermal field, whilst mixing with local groundwater aquifers occurs towards the field margin. Reservoir rocks in the Kawerau geothermal system comprise locally vented lavas (e.g. Kawerau Andesite, Caxton and Onepu Formation), and distally-sourced silicic pyroclastic rocks (e.g. Raepahu Formation and Te Teko Formation), which unconformably overlie the greywacke basement. Lacustrine sediments, and welded intervals within some ignimbrite units, act as localised aquicludes and separate the volcaniclastic units into discrete aquifers.

Figure 1.10 shows a southeast-northwest profile through the Kawerau Geothermal Field, with inferred isotherms defined by measured well temperatures. Drillhole permeability data helps to define the extent of the reservoir, with the reservoir boundary inferred from resistivity and gravity surveys. Resistivity data, combined with the inferred location of the main heat and 
mass outflow, is consistent with deeply-sourced thermal fluids flowing from the south towards the northern part of the field. A subsurface outflow is inferred to extend to the north, with progressive dilution and cooling of the geothermal fluid as it mixes with groundwater beneath the Tarawera-Rangitaiki flood plain (Bignall, 2011).

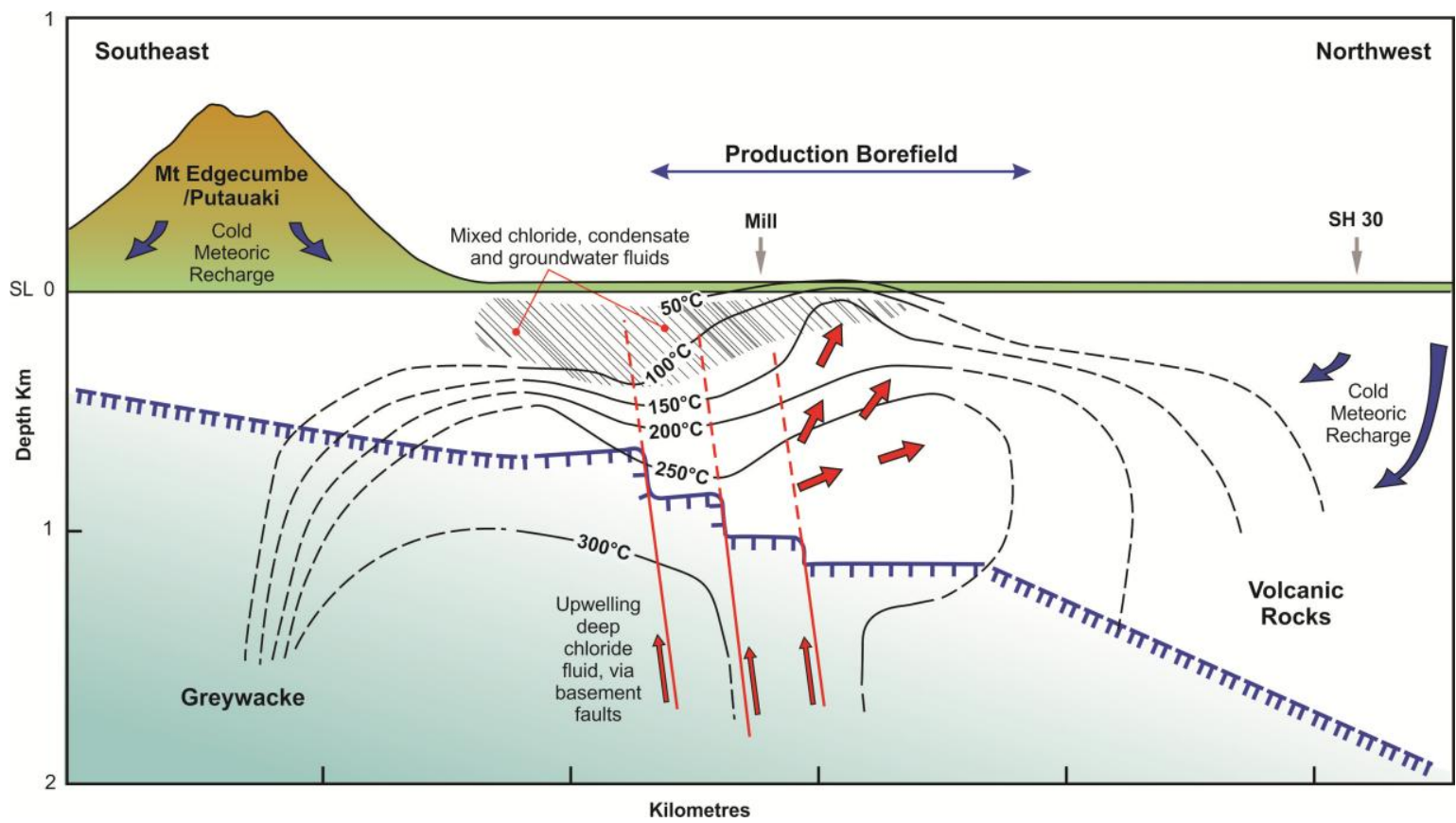

Figure 1.10 Conceptual model of the Kawerau Geothermal Field (after Holt, 2007). The approximate line of the cross section is shown in Fig. 1.6.

\subsection{THESIS CONTENTS}

CHAPTER 1 introduces key concepts in the understanding of geothermal systems and places the Kawerau geothermal system within its context of the high-temperature geothermal systems in New Zealand. It then introduces the geological setting of the Kawerau geothermal system, looking at the historic surface features, geophysical studies and prior understanding of the geology of the area.

CHAPTER 2 summarises the zircon U-Pb dating undertaken on selected samples from the Kawerau Geothermal Field. In addition to traditional approaches of mineralogy and petrography, these data are applied to the correlation of hydrothermally altered rocks in the geothermal system. This chapter has been published as a paper in the Journal of Volcanology and Geothermal Research (Milicich et al., 2013a).

CHAPTER 3 revises the stratigraphy of the Kawerau Geothermal Field utilising the zircon $\mathrm{U}-\mathrm{Pb}$ dates presented in Chapter 2 and relates this to the structural development of the field within the context of the wider development of the Whakatane Graben and Taupo Volcanic Zone. This chapter has been published as a paper in the Journal of Volcanology and 
Geothermal Research (Milicich et al., 2013b).

CHAPTER 4 utilises the new dating information and revised stratigraphy to create a 3-D visualisation of the geology of the Kawerau area. This chapter has been submitted as a paper to Geothermics (Milicich et al., 2013c).

CHAPTER 5 considers the geochemistry of the alteration minerals, with the aim of deciphering past expressions of the Kawerau geothermal system and the source of fluids in the system (i.e. meteoric vs. magmatic inputs). This aspect of the work uses cathodoluminescence imagery, stable isotope analyses and fluid inclusion microthermometry.

CHAPTER 6 concludes the thesis by providing a summary of the current state of knowledge regarding the geological history and structural development of the Kawerau geothermal system. It assimilates the key results from each chapter, and highlights the directions that future research should pursue to develop a more complete understanding of the Kawerau geothermal system.

Several appendices are included in this thesis, in either print or electronic form.

Appendix A: Graphical well logs that were an electronic supplement to the paper presented in Chapter 3 (Milicich et al., 2013b).

Electronic appendices are included on $\mathrm{CD}$ with this thesis:

Electronic Appendix 1: Summary of the new stratigraphic descriptions applied to well logs from the field. The data in this appendix were used to inform the outcomes of Chapters 2 and 3, but are not formally referenced until Chapter 3. This appendix is published as a GNS Science Report (Milicich, 2013b).

Electronic Appendix 2: Petrographic thin-section descriptions of selected core and cuttings samples from the Kawerau Geothermal Field. Many of these samples were dated by $\mathrm{U}-\mathrm{Pb}$ techniques on zircons (Chapter 2; Milicich et al., 2013a). The data in this appendix were used to inform the outcomes of Chapters 2 and 3, but are not formally referenced until Chapter 3. This appendix is published as a GNS Science Report (Milicich, 2013a).

Electronic Appendix 3: Conference papers and abstracts arising from this work.

Electronic Appendix 4: Data set from SHRIMP-RG U-Pb dating of zircons that was an electronic supplement to the paper presented in Chapter 2 (Milicich et al., 2013a). 
Electronic Appendix 5: Video file of the 3-D visualisation of the faulting structure in the Kawerau geothermal system. This file forms an electronic supplement to the paper presented in Chapter 4 (Milicich et al., 2013c).

Electronic Appendix 6: Video file of the 3-D visualisation of the geology of the Kawerau geothermal system. This file forms an electronic supplement to the paper presented in Chapter 4 (Milicich et al., 2013c).

Electronic Appendix 7: Images of fluid inclusion plates. The numbers of these plates refers to the summary table in Electronic Appendix 8.

Electronic Appendix 8: Raw data from fluid inclusion microthermometry. These data were used to create the summary tables presented in Chapter 5.

Electronic Appendix 9: Summary of the fluid inclusion assemblages plotted on plane light or cathodoluminescence images of the analysed hydrothermal minerals. 
Chapter 1 


\section{CHAPTER 2}

\section{U-PB DATING OF ZIRCON IN HYDROTHERMALLY ALTERED ROCKS OF THE KAWERAU GEOTHERMAL FIELD, TAUPO VOLCANIC ZONE, NEW ZEALAND}

Sarah D. Milicich, Colin J.N. Wilson, Greg Bignall, Ben Pezaro, Bruce L.A. Charlier, Joe L.

Wooden, Trevor R. Ireland

Paper published by Journal of Volcanology and Geothermal Research

Manuscript http://dx.doi.org/10.1016/j.jvolgeores.2012.12.016

Statement of authorship: SDM undertook the logging, correlation work, and zircon picking.

CJNW, BP, BLAC, JLW and TRI assisted SDM with collection of U-Pb data. CJNW and GB assisted SDM with interpretation of data. All authors assisted SDM with editing of the manuscript. 


\section{ABSTRACT}

Crystallisation-age spectra have been obtained by SIMS techniques (SHRIMP-RG) on zircons from altered volcanic units penetrated by drillholes at Kawerau Geothermal Field in the central Taupo Volcanic Zone (TVZ), New Zealand. Drillholes penetrate $700-1300 \mathrm{~m}$ of volcanic rocks and sediments before reaching the basement Mesozoic greywacke. Twentyseven samples of altered volcanic lithologies and two surficial, fresh rock units have been studied in order to constrain ages of the major stratigraphic units. Within the volcanic/sedimentary pile the oldest in-situ ignimbrites that can be widely correlated have ages of $\sim 1.45 \mathrm{Ma}$. Between them and the basement greywacke is a variable thickness of sediments, mostly greywacke gravels and minor volcaniclastic units, reflecting localised basinal deposition associated with strike-slip faulting. Two ignimbrites within this sequence yield age estimates of c. 2.4 and $2.1 \mathrm{Ma}$, consistent with these being distal southern Coromandel Volcanic Zone deposits, pre-dating TVZ activity. Below the regional marker plane of the 0.32 Ma Matahina ignimbrite, three main ignimbrite groups occur, with ages around 1.45 Ma, 1.0 $\mathrm{Ma}$ and $0.6-0.5 \mathrm{Ma}$, which are separated by sediment-dominated intervals and andesite volcanics. All of these ignimbrites represent marker horizons from other volcanic centres and do not reflect the presence of local magmatic heat sources.

Numerous bodies of coherent rhyolite, previous labelled as Caxton and Onepu rhyolites, have been intersected at all pre-Matahina ignimbrite levels (including within the basement greywacke) and reflect earlier local magmatic heat sources. Our geochronological data resolve these rock bodies into three packages. The youngest is represented by the surficial rhyodacite Onepu domes, ${ }^{40} \mathrm{Ar} /{ }^{39} \mathrm{Ar}$ dated at $0.138 \pm 0.007 \mathrm{Ma}$. U-Pb ages on zircons from dome material yield a spectrum that can be matched (consistent with petrography) with two dikes intersected at $880 \mathrm{~m}$ and $2.67 \mathrm{~km}$ depth, and with an estimated age of $0.15 \pm 0.01 \mathrm{Ma}$ (Onepu Formation). The older two packages consist of older crystal rich $(\sim 15 \%)$ and younger crystalpoor $(\sim 5 \%)$ rhyolite, here grouped as Caxton Formation and with eruption/intrusion age of $0.36 \pm 0.03 \mathrm{Ma}$. The shallowest Caxton rhyolite bodies are interpreted to be domes, while deeper intersections are inferred to be sills based on the lateral extents relative to thicknesses.

Net subsidence rates inferred from depths to key units do not reflect the present-day situation. Modern rates of subsidence $(2 \pm 1 \mathrm{~mm} / \mathrm{yr})$ associated with TVZ rifting processes can have been active for no more than $\sim 50,000$ years, based on elevation differences of the Matahina ignimbrite top surface. An inferred change in intrusion geometry from sill (Caxton) to dike (Onepu) indicates a change in principal stress orientations reflecting onset of the modern Whakatane Graben. This change is dated at $\sim 0.37 \mathrm{Ma}$ in coastal sedimentary 
sequences $23 \mathrm{~km}$ to the north of Kawerau, consistent with our age data. Although previously interpreted to be a long-lived system, the modern Kawerau Geothermal Field is a Holocene entity reflecting the rejuvenation of magmatic heat flux associated with Putauaki volcano superimposed on an area of multiple reactivated fault structures, sporadic magmatism and variable rates of subsidence.

\section{$2.1 \quad$ INTRODUCTION}

The successful exploration and management of high-temperature geothermal systems for electrical power generation and direct heat usage requires an understanding of the geological structure and permeability pathways (including faults) within the system. Central to sound interpretation of the geological structure is dating and correlating key marker horizons, in order to correlate laterally permeable formations and estimate the timing and rates of movements across faults. The correlation of hydrothermally altered rocks is challenging, due to similarities in the lithologies, and the destruction by hydrothermal alteration of distinctive chemical, mineralogical and groundmass textural characteristics. A further complexity in volcanic terrains is that the original depositional surface may not be flat, so apparent offsets of the same units between drillholes may not be due to later displacement but instead reflect primary topographic relief. Although correlations can be made on the basis of petrographic characteristics (rock type, crystal content, presence and abundance of recognisable mineral phases), such relationships may be made ambiguous by overprinting hydrothermal alteration. In order to establish a sound chronostratigraphic sequence in a geothermal field, key information is the ages of the lithologies, especially when these can be used to differentiate or correlate between units within and beyond the geothermal field (e.g., Wilson et al., 2008, 2010).

Many intermediate to evolved volcanic rock compositions, particularly rhyolites, contain as a trace mineral phase zircons that crystallised in the magma prior to quenching by eruption (Hoskin and Schaltegger, 2003). The zircons (or portions within the crystals) can be dated by U-Th disequilibrium or U-Pb techniques (Schmitt, 2011, for review) to give insight into the age patterns of crystallization within the parental magma. Zircons are valuable repositories of age information due to their resistance to hydrothermal alteration, replacement or recrystallisation that partially or completely affects the other minerals and groundmass in the rocks. Dating individual zircons provides a spectrum of crystallisation ages for primary magmatic material in these rocks. The peak of zircon crystallisation provides a maximum age limit on the eruption(s) concerned, or provides an approximation to the emplacement age for 
intrusive rocks, while the youngest zircons provide a close approximation to eruption age (e.g. Dalrymple et al., 1999; Schmitt et al., 2003a). A combination of age data and geological studies then permits the thermal and structural history of geothermal fields to be inferred (e.g. Norton and Hulen, 2001; Stimac et al., 2001; Schmitt et al., 2003b).

Interpretation of the age spectra obtained from zircons in hydrothermally altered rocks depends, however, on the nature of the material available for sampling and its inferred history. Ideally, zircons are extracted from coherent rock which represents an aliquot of magmatic material (hand specimen of lava or intrusive material, or single juvenile pyroclasts). However, since much of the primary volcanic material in volcanic-hosted geothermal systems is pyroclastic in origin, samples of tuff tend to be used, which may contain fragments of accidental lithic material or intermixed ash-sized material from older rocks. Secondly, the nature of the downhole-sampled material is important. If core is used, then the sample is derived from a known depth in a given lithology, and downhole contamination can be eliminated as a source of diversity in the zircon age spectra. If only cuttings are available, then not only may it be difficult to establish the nature of the rock host, but the possibility of downhole contamination from the open-hole section above the drill bit becomes an issue. Cuttings samples are ideally collected from directly below well casing points to minimise this issue. The use of cathodoluminescence (CL) and petrography can be used to reduce the uncertainty introduced by non-ideal samples.

In this paper we report $\mathrm{U}-\mathrm{Pb}$ age data obtained from a sequence of strongly hydrothermally altered rocks sampled as mostly core and some cuttings from wells in the Kawerau Geothermal Field in New Zealand. Despite extensive alteration of the primary volcanic mineral assemblages in the samples, the zircon crystals appear almost entirely unaffected by the hydrothermal activity (either in the form of dissolution or by overgrowths visible under cathodoluminescence). We show how age data from the zircons can be used to constrain interpretations of stratigraphy where conventional petrographic information might be ambiguous or inaccurate. A challenge correlating stratigraphy at Kawerau is the absence of a marker horizon that is present across all wells in the field. Consequently, $\mathrm{U}-\mathrm{Pb}$ age data have proved valuable, balanced with petrographic observations, in deciding on an overall stratigraphic sequence. The new chronology established here is then used in a companion paper (Milicich et al., 2013b) to revise the stratigraphic and structural history of the Kawerau Geothermal Field. 


\subsection{KAWERAU GEOTHERMAL FIELD}

Kawerau Geothermal Field is one of 23 active high-temperature geothermal fields in the Taupo Volcanic Zone (TVZ) of New Zealand (Fig. 2.1; Bibby et al., 1995; Rowland and Sibson, 2004; Kissling and Weir, 2005; Rowland and Simmons, 2012). The onshore TVZ is a rifted arc that is segmented into three parts (Healy, 1962; Wilson et al., 1995a). The central portion is dominated by exceptionally vigorous rhyolitic caldera volcanism, and also contains most of the high-temperature geothermal systems, whilst the northern and southern segments are dominated by andesite-dacite composite-cone volcanism with localised geothermal systems (Bibby et al., 1995; Wilson et al., 1995a; Fig. 2.1). Kawerau is situated at the northeastern limit of the central TVZ where sources of voluminous silicic volcanism and associated magmatism to the southwest merge into the andesite-dacite northern TVZ arc (Nairn, 2002). Structurally, the Kawerau Field lies within the southern part of the northeasttrending Whakatane Graben, in a zone where the active TVZ rift structures intersect the north-striking strike-slip faults of the North Island Shear Belt (Nairn and Beanland, 1989; Mouslopoulou et al., 2007; Begg and Mouslopoulou, 2010; Villamor et al., 2011). The TVZ graben structure is well expressed at Kawerau, where the $0.322 \pm 0.007$ Ma Matahina ignimbrite (Bailey and Carr, 1994; Leonard et al., 2010) is exposed at the surface east of the field, but occurs at 10 to $130 \mathrm{~m}$ depth beneath the field itself. The Matahina ignimbrite and pre-0.322 Ma volcanic rocks crop out west and northwest of the field, and are extensively faulted and uplifted to form the western shoulder of the modern Whakatane Graben.

The Quaternary volcanic rocks of the TVZ, and earlier Miocene-Pliocene volcanic rocks of the Coromandel-Kaimai area to the northwest (see Booden et al., 2012 for a review), rest on indurated metasediments ('greywacke') accreted to the margin of Gondwanaland during the Mesozoic (Mortimer, 2004; Adams et al., 2009; Leonard et al., 2010). During the Quaternary, greywacke within the Whakatane Graben has been downfaulted to $1-2 \mathrm{~km}$ below sea level, with the resulting structural depression infilled continuously by the Quaternary volcanic rocks and sediments. The greywacke has been penetrated by numerous wells within the field and the lower limits of the volcanic and sedimentary sequence are clearly defined. 


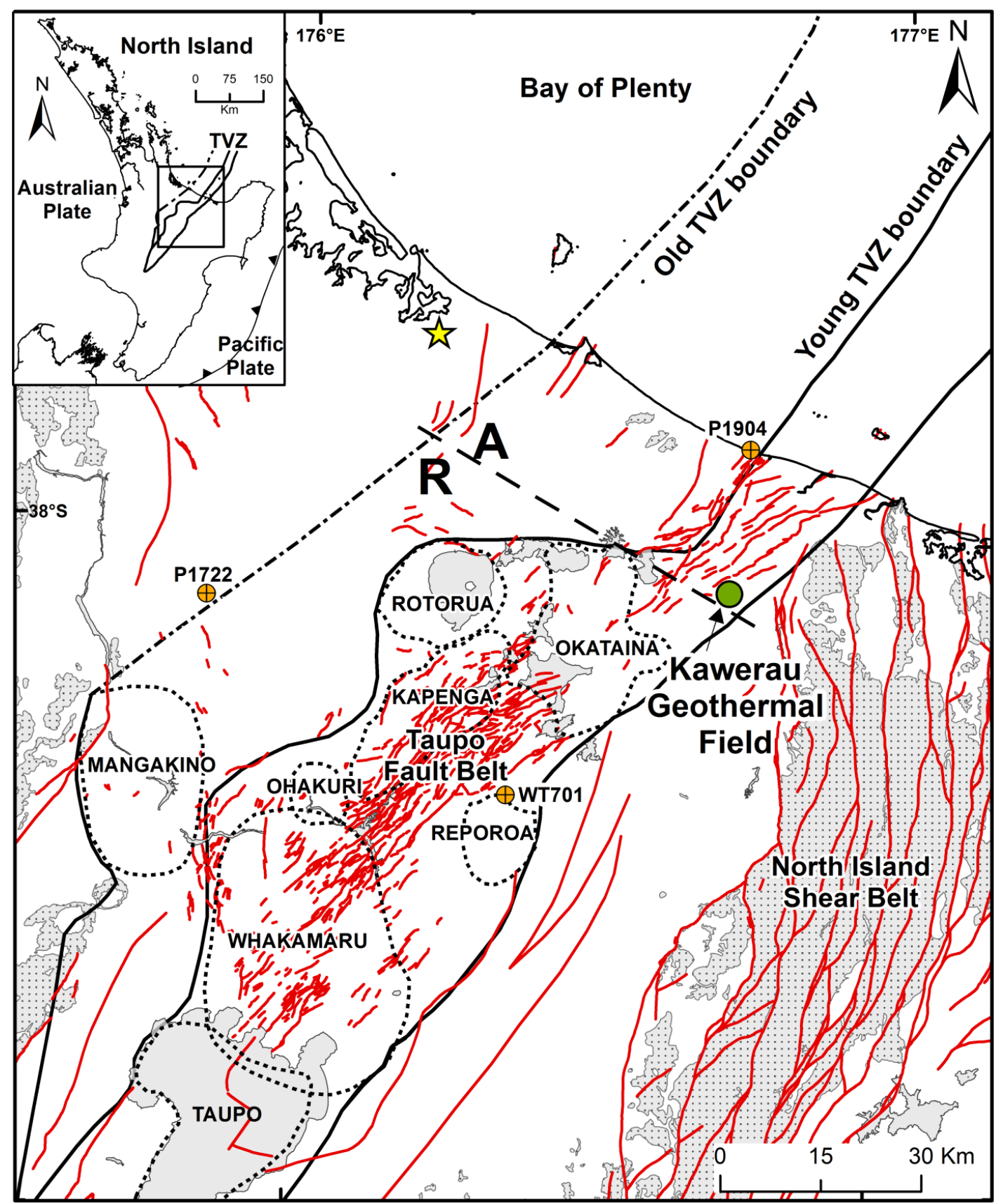

Figure 2.1 Locality map for the Taupo Volcanic Zone (TVZ) with the Kawerau Geothermal Field studied in this paper. Old (1.6 Ma to $340 \mathrm{ka}$ ) and young (340 ka to present) boundaries to the TVZ are shown, with its subdivisions into andesite-dominated (A) extremities and the rhyolite dominated (R) central segment. Faults in red (from Leonard et al., 2010). Caldera boundaries dashed (from Wilson et al., 2009). Locations of samples P1722, P1904 and WT701 referred to in the text are indicated. The location of surface outcrops of Papamoa Ignimbrite (from Briggs et al., 2005) are indicated by a star.

\subsection{SURFACE AND SUBSURFACE STRATIGRAPHY AT KAWERAU}

The $0.322 \pm 0.007$ Ma Matahina ignimbrite is the oldest surficial unit in the Kawerau area (Fig. 2.2), exposed to the southeast of the field and intersected by many drillholes in the field. The rhyodacitic Onepu domes on the western margin of the field are bracketed in age between the 
Matahina and overlying 61 ka Rotoiti ignimbrites (Wilson et al., 2007; Cole et al., 2010). A ${ }^{40} \mathrm{Ar} /{ }^{39} \mathrm{Ar}$ age of $0.138 \pm 0.007 \mathrm{Ma}$ determined by M.A. Lanphere (U.S. Geological Survey) and B.F. Houghton on material from the Onepu domes is recorded in unpublished files held by GNS Science and has been cited (without uncertainty) by Christenson (1997). The modern volcanic landscape at Kawerau is dominated by Putauaki (Mt. Edgecumbe), a Holocene, multiple vent andesite-dacite volcano (Nairn, 2002), which last erupted at $2400{ }^{14} \mathrm{C}$ years B.P. (Carroll et al., 1997). Other geological units exposed in the area are young pyroclastic deposits from Okataina Volcanic Centre, and Holocene alluvial material (Nairn, 2002; Cole et al., 2010). The Tarawera River runs through the centre of the field, with its volcanic-related alluvial deposits (Hodgson and Nairn, 2005; Manville et al., 2007) forming much of the surficial geology and burying fault scarps and details of the pre-Holocene geology.

More than 70 wells (Fig. 2.2) have been drilled in the field for various purposes, although generally around 12 wells have been in production for geothermal steam at any one time. The stratigraphy encountered during drilling at Kawerau has previously been differentiated by Nairn (1977, 1981, 1982, 1986), Grindley (1986), Christenson (1987) and Allis et al. (1995), and is summarised by Bignall and Harvey (2005). The pre-existing stratigraphic framework used by these authors is inconsistent, however, with many of the stratigraphic names incorrectly applied across the field. This is particularly true for the deeper units such as the previously termed Te Teko and Opunoke ignimbrites, where these unit names have been applied to some rocks that bear little resemblance to the original lithologic description. In order to address this problem, a complete review and revision of the Kawerau Geothermal Field stratigraphy was deemed necessary, and has consequently been undertaken in the light of the new age determinations presented in this paper. A summary of this stratigraphy is given in Table 2.1 and detailed in Milicich et al. (2013b). The volcanic succession in the field rests on Mesozoic volcaniclastic and plutoniclastic sandstone (greywacke) and siltstone (argillite) of broadly intermediate composition and linked to the Waioeka Petrofacies of the Torlesse (composite) terrane (Wood et al., 2001; Adams et al., 2009; Leonard et al., 2010). 


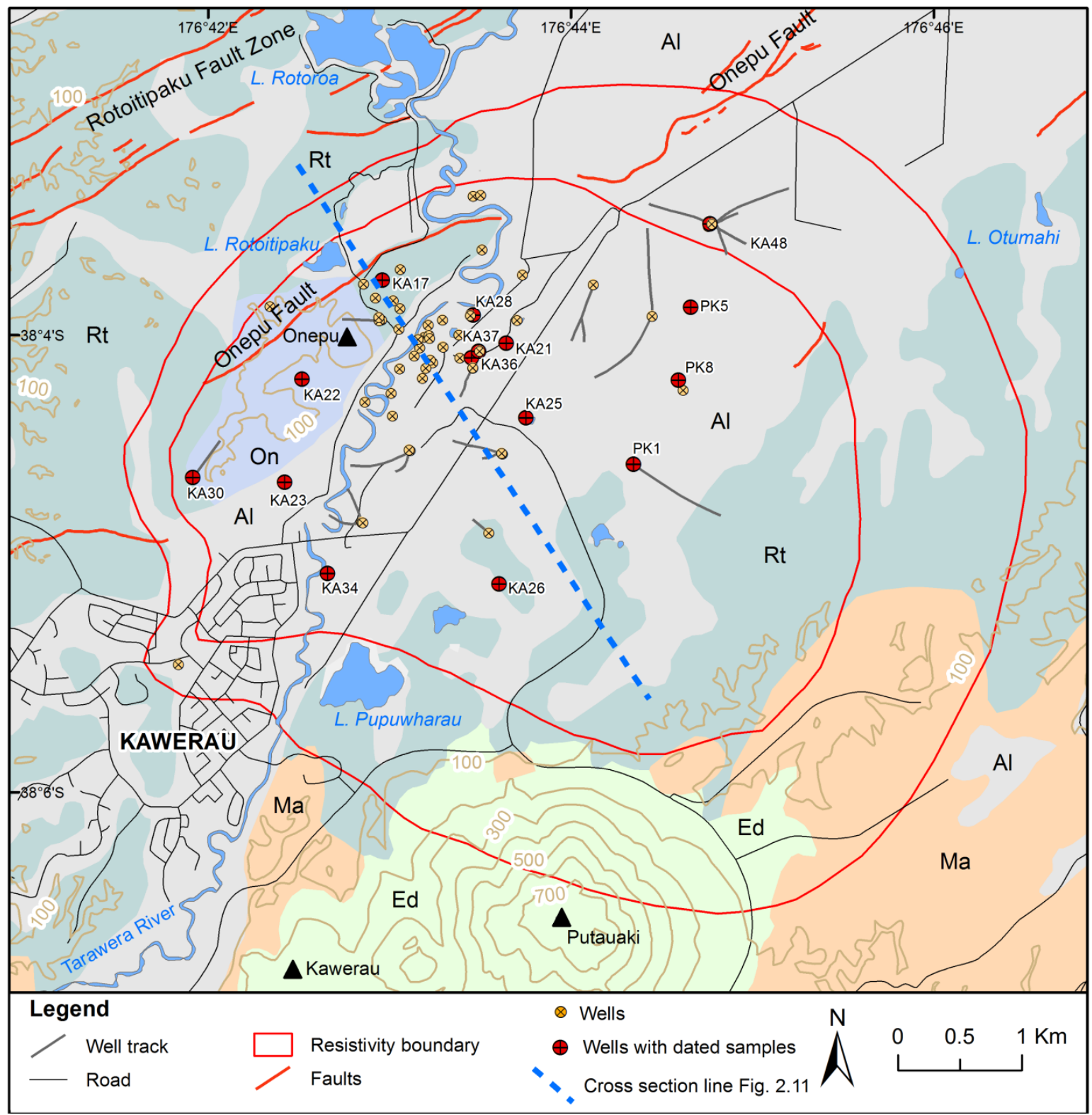

Figure 2.2 Map of Kawerau Geothermal Field showing drillholes, active faults (GNS Science, 2013), and approximate resistivity boundary zone at about $500 \mathrm{~m}$ depth (after Allis, 1997). Key to simplified geology map units (after Leonard et al., 2010): Ma - Matahina ignimbrite; Rt - Rotoiti and Mangaone ignimbrites; $\mathrm{Al}$ - volcaniclastic alluvial deposits from breakout floods down the Tarawera River (Hodgson and Nairn, 2005); Ed - lavas of Putauaki volcano (Mount Edgecumbe: Nairn, 2002); On - Onepu rhyolite domes. Cross section line of Fig 2.11 is indicated with the dashed blue line. 
Table 2.1 Summary of the main stratigraphic units and lithologies in the Kawerau Geothermal Field (from Milicich et al., 2013b).

\begin{tabular}{|c|c|c|}
\hline Formation & Lithology & Thickness \\
\hline Recent Alluvium & $\begin{array}{l}\text { Peat deposits; sands and gravels; unconsolidated pyroclastics (incl. Whakamana } \\
\text { Breccia, Rotoiti Breccia) }\end{array}$ & $10-50 \mathrm{~m}$ \\
\hline Hydrothermal Eruption Breccias & Hydrothermal eruption deposits, from $\sim 16,000$ and $\sim 9,000 \mathrm{yr} \mathrm{BP}$ & $1-4 \& 2-10 \mathrm{~m}$ \\
\hline Unconsolidated pyroclastics & Unwelded pumiceous pyroclastic flows and airfall tuffs & $0-90 \mathrm{~m}$ \\
\hline Onepu Formation & $\begin{array}{l}\text { Twin surficial domes of rhyodacite (pl, qz, pyx, hb, bt) and intrusive } \\
\text { (porphyritic crystal-rich; corroded qz, pl, mafics) }\end{array}$ & $\sim 200 \mathrm{~m}$ \\
\hline Matahina ignimbrite & Partly welded grey-brown ignimbrite \& vitric tuff (pl, qz, pyx) & $10-410 \mathrm{~m}$ \\
\hline Tahuna Formation & $\begin{array}{l}\text { Crystal-rich, fine sandstone, siltstone, muddy lithic-breccia and unwelded } \\
\text { pumice-rhyolite lapilli tuff }\end{array}$ & $0-360 \mathrm{~m}$ \\
\hline Caxton Formation & $\begin{array}{l}\text { Buried domes of spherulitic and banded rhyolite (corroded and fractured qtz } \\
\text { and } \mathrm{pl} \text { ) and intrusive (corroded and fractured } \mathrm{qz} \text { and } \mathrm{pl}, \pm \mathrm{bt} \pm \mathrm{amp} \text { ) }\end{array}$ & $0-450 \mathrm{~m}$ \\
\hline Karaponga Formation & Partly welded crystal-lithic tuffs (pl, qtz \pm bt) & $0-180 \mathrm{~m}$ \\
\hline Onerahi Formation & Tuffaceous to muddy breccias and coarse tuffaceous sandstone & $0-85 \mathrm{~m}$ \\
\hline Kawerau Andesite & Augite-plagioclase andesite flows, breccias and tuff (in south) & $0-300 \mathrm{~m}$ \\
\hline Raepahu Formation & $\begin{array}{l}\text { Partly welded crystal-vitric tuffs (qz, pl, bt, lithic-poor and qz, pl, bt, } \\
\text { ferromagnesians, lithic-rich) }\end{array}$ & $0-165 \mathrm{~m}$ \\
\hline Tasman Formation & $\begin{array}{l}\text { Muddy breccia, sandstone and siltstone, but widely represented by reddish } \\
\text { brown siltstone }\end{array}$ & $0-25 \mathrm{~m}$ \\
\hline Te Teko Formation & Partly welded grey crystal-vitric tuff (corroded qz, pl, bt) & $0-255 \mathrm{~m}$ \\
\hline Rotoroa Formation & Tuffaceous sandstone, poorly sorted crystal and vitric, water-laid tuff, siltstone & $0-200 \mathrm{~m}$ \\
\hline Waikora Formation & Greywacke pebble conglomerate and minor intercalated tuff and siltstone & $0-450 \mathrm{~m}$ \\
\hline Greywacke basement & Weathered, sheared greywacke and argillite & - \\
\hline
\end{tabular}

Abbreviations used are $\mathrm{pl}=$ plagioclase; $\mathrm{qz}=$ quartz; $\mathrm{px}=$ pyroxene; $\mathrm{hbl}=$ hornblende; $\mathrm{bt}=$ biotite; amp = amphibole.

\subsection{SAMPLES AND ANALYTICAL METHODS}

\subsubsection{Sample suite}

All the rocks in the Kawerau drillholes show significant degrees of hydrothermal alteration, with the exception of some of the shallowest material and from the margins of the field. The degree of alteration is such that little remains of the original volcanic plagioclase and ferromagnesian minerals, with these being variably replaced by quartz, adularia, albite, clay, calcite, chlorite, titanite, pyrite and epidote. Twenty seven samples were taken for this study from key ignimbrites, tuffs and coherent rhyolite across the field (Table 2.2; Fig. 2.3). 


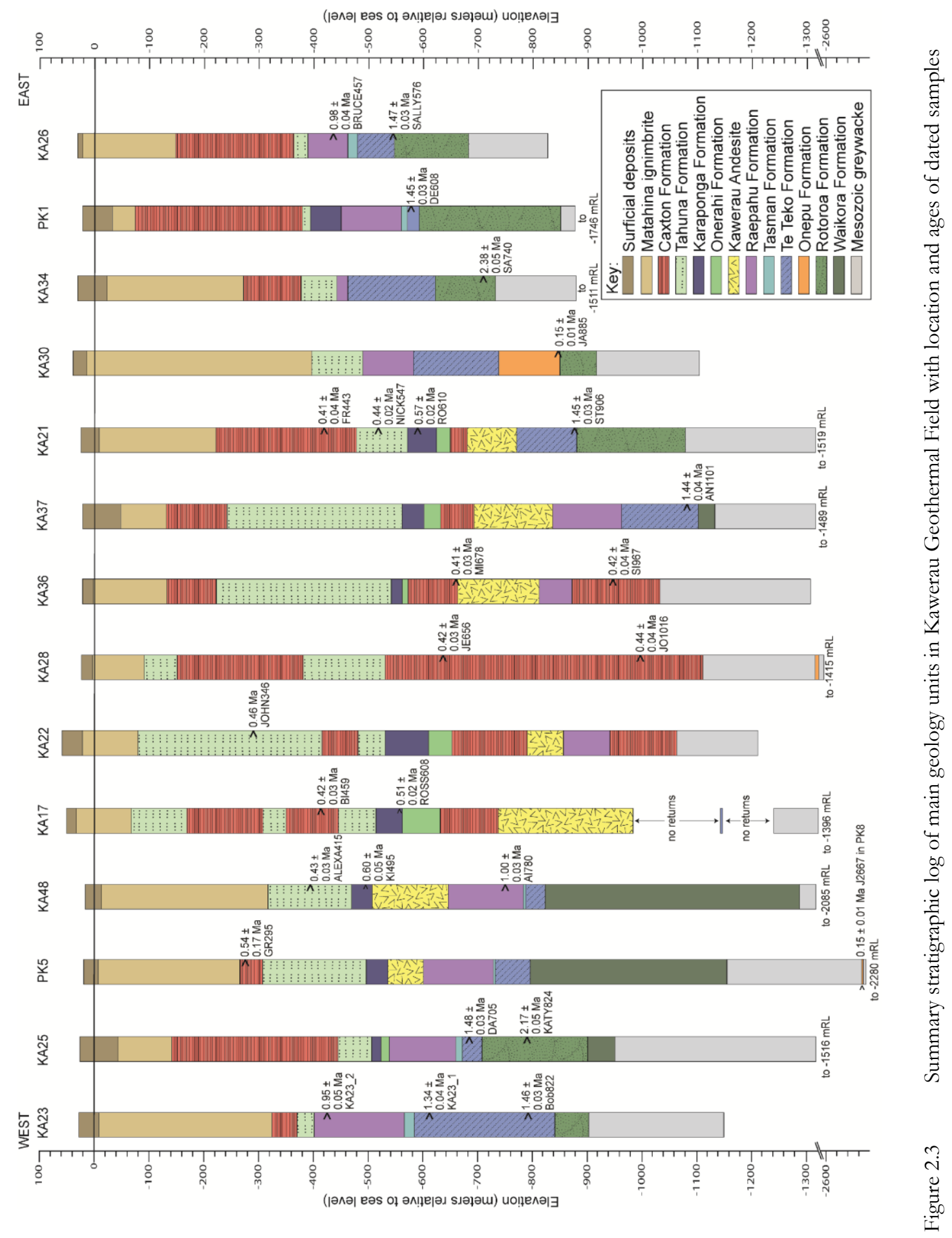


Table 2.2 Samples analysed for U-Pb dating on zircons.

\begin{tabular}{|c|c|c|c|c|c|c|c|c|c|c|c|c|}
\hline \multirow{3}{*}{$\begin{array}{l}\text { Well } \\
\mathrm{n} / \mathrm{a}\end{array}$} & \multicolumn{2}{|c|}{$\begin{array}{l}\text { Depth } \\
(\mathrm{m})\end{array}$} & \multicolumn{2}{|c|}{$\begin{array}{l}\text { Depth } \\
\text { (mRL) }\end{array}$} & \multirow[t]{2}{*}{$\begin{array}{l}\text { Sample label } \\
\text { for lab work }\end{array}$} & \multirow[t]{2}{*}{ Lithology } & \multirow[t]{2}{*}{ Sample material } & \multirow[t]{2}{*}{ Stratigraphic unit } & \multicolumn{2}{|c|}{$\begin{array}{l}\text { Number of } \\
\text { analyses }\end{array}$} & \multirow[b]{2}{*}{ Figure } & \multirow[b]{2}{*}{ Table } \\
\hline & from & to & from & to & & & & & total & viable & & \\
\hline & \multicolumn{4}{|c|}{ Surface exposure } & P1904 & Pumice clast & Hand specimen & Quartz-biotite ig. & 37 & 30 & 2.7 & 2.5 \\
\hline $\mathrm{n} / \mathrm{a}$ & \multicolumn{4}{|c|}{ Surface exposure } & D068 & Coherent rhyolite & Hand specimen & Onepu Formation & 13 & 7 & 2.10 & - \\
\hline KA30 & 885 & 887 & -845 & -847 & JA885 & Coherent rhyolite & Core & Onepu Formation & 15 & 14 & 2.10 & - \\
\hline PK8 & 2667 & & -2647 & & $\mathrm{~J} 2667$ & Coherent rhyolite & Core & Onepu Formation & 11 & 7 & 2.10 & - \\
\hline PK5 & 295 & 325 & -275 & -305 & GR295 & Coherent rhyolite & Cuttings & Caxton Formation & 11 & 6 & 2.9 & 2.6 \\
\hline KA21 & 444 & 445 & -418 & -419 & FR443 & Coherent rhyolite & Core & Caxton Formation & 7 & 7 & 2.9 & 2.6 \\
\hline KA17 & 459 & 460 & -408 & -410 & BI459 & Coherent rhyolite & Core & Caxton Formation & 33 & 30 & 2.9 & 2.6 \\
\hline KA28 & 656 & 658 & -631 & -633 & JE656 & Coherent rhyolite & Core & Caxton Formation & 30 & 29 & 2.9 & 2.6 \\
\hline KA36 & 678 & 680 & -655 & -657 & MI678 & Coherent rhyolite & Core & Caxton Formation & 16 & 14 & 2.9 & 2.6 \\
\hline KA36 & 967 & 969 & -944 & -946 & SI967 & Coherent rhyolite & Core & Caxton Formation & 10 & 9 & 2.9 & 2.6 \\
\hline KA28 & 1016 & 1018 & -991 & -993 & JO1016 & Coherent rhyolite & Core & Caxton Formation & 30 & 29 & 2.9 & 2.6 \\
\hline KA22 & 345 & 347 & -284 & -286 & JOHN346 & Tuff & Core & Tahuna Formation & 12 & 9 & 2.8 & 2.5 \\
\hline KA48 & 415 & 420 & -397 & -402 & ALEXA415 ' & Tuff & Cuttings & Tahuna Formation & 47 & 43 & 2.8 & 2.5 \\
\hline KA21 & 547 & 548 & -521 & -523 & NICK547 & Tuff & Core & Tahuna Formation & 42 & 41 & 2.8 & 2.5 \\
\hline KA48 & 495 & 515 & -477 & -497 & KI495 & Tuff & Cuttings & Karaponga Formation & 19 & 19 & 2.7 & 2.5 \\
\hline KA17 & 609.6 & 611.1 & -559 & -560 & ROSS608 & Welded ignimbrite & Core & Karaponga Formation & 41 & 37 & 2.7 & 2.5 \\
\hline KA21 & 610 & 612 & -585 & -586 & RO610 & Welded ignimbrite & Core & Karaponga Formation & 30 & 24 & 2.7 & 2.5 \\
\hline KA23 & 454 & & -426 & & KA23_2 & Welded ignimbrite & Core & Raepahu Formation & 42 & 39 & 2.6 & 2.4 \\
\hline KA26 & 457 & 459 & -426 & -428 & BRUCE457 & Welded ignimbrite & Core & Raepahu Formation & 31 & 27 & 2.6 & 2.4 \\
\hline KA48 & 780 & 781 & -747 & -776 & AI780 & Welded ignimbrite & Cuttings & Raepahu Formation & 28 & 26 & 2.6 & 2.4 \\
\hline KA26 & 577 & 579 & -545 & -547 & SALLY576 & Welded ignimbrite & Core & Te Teko Formation & 21 & 18 & 2.5 & 2.3 \\
\hline PK1 & 608 & 611 & -578 & -580 & DE608 & Welded ignimbrite & Core & Te Teko Formation & 51 & 49 & 2.5 & 2.3 \\
\hline KA23 & 637 & & -609 & & KA23_1 & Welded ignimbrite & Core & Te Teko Formation & 60 & 58 & 2.5 & 2.3 \\
\hline KA25 & 705 & 706 & -677 & -678 & DA705 & Welded ignimbrite & Core & Te Teko Formation & 27 & 25 & 2.5 & 2.3 \\
\hline KA23 & 822 & 824 & -794 & -796 & BOB822 & Welded ignimbrite & Core & Te Teko Formation & 17 & 15 & 2.5 & 2.3 \\
\hline KA21 & 906 & 907 & -880 & -882 & ST906 & Welded ignimbrite & Core & Te Teko Formation & 50 & 50 & 2.5 & 2.3 \\
\hline KA37 & 1101 & 1104 & -1078 & -1081 & AN1101 & Welded ignimbrite & Core & Te Teko Formation & 49 & 49 & 2.5 & 2.3 \\
\hline KA34 & 740 & 742 & -707 & -709 & SA740 & Welded ignimbrite & Core & Rotoroa Formation & 24 & 22 & 2.4 & - \\
\hline KA25 & 824 & 826 & -796 & -798 & KATY824 & Tuff & Core & Rotoroa Formation & 15 & 13 & 2. & - \\
\hline
\end{tabular}

See Fig. 2.1 for well locations and Table 2.1 for stratigraphic units.

Depths are in metres below the well head, while depths mRL are relative to sea level.

Sample labels are informal names used in sample preparation and laboratory work in order to minimise the risk of confusion between samples from the same well.

In the lithology, 'Coherent rhyolite' is used informally to refer to quartz-bearing material that was coherent (i.e., lava or intrusive material) rather than a welded ignimbrite or other pyroclastic rock ('Tuff').

The total number of analyses is all those obtained; 'viable' analyses refer to those Quaternary grains with acceptable levels of common-Pb (see text), excluding Mesozoic greywacke grains (see Electronic Appendix 4). 


\subsubsection{Sample preparation}

Drillcore and cuttings samples were ground in a ringmill prior to sieving to yield a $30-250$ $\mu \mathrm{m}$ size fraction. Concentration of heavy minerals was achieved by density separation using lithium polytungstate. The concentrates were rinsed in warm nitric acid to remove often high amounts of pyrite. Due to the presence of other dense alteration minerals (often titanite), zircons were hand-picked from a final concentrate.

\subsubsection{Ion probe analytical techniques for ion probe}

Age determinations on zircons were made by Secondary Ion Mass Spectrometry (SIMS) techniques on the SHRIMP-RG instruments at the joint USGS-Stanford University facility (SUMAC) and at the Research School of Earth Sciences, Australian National University (ANU). The techniques used were those described in Dalrymple et al. (1999), as modified by Wilson et al. (2010). Zircons were mounted in epoxy resin, polished to expose the cores of the grains, photographed in reflected light, and imaged by cathodoluminescence. To minimise contamination by common $\mathrm{Pb}$, the mounts were cleaned in either: (a) detergent, petroleum spirits and $1 \mathrm{~N} \mathrm{HCl}$ (ANU), or (b) detergent and $1 \mathrm{~N} \mathrm{HCl}$ (SUMAC), with intervening rinses in distilled water. The epoxy mounts were then sputtered with gold to a thickness of $3 \mathrm{~nm}$ prior to leading into the instrument. The primary beam was rastered for $180 \mathrm{~s}$ on a $150 \mu \mathrm{m}^{2}$ area prior to data acquisition to remove any possible surface contamination. Ions were sputtered from zircons with a $5-6 \mathrm{nA}$ primary $\mathrm{O}_{2}{ }^{-}$beam focused to a $25 \times 35 \mu \mathrm{m}$ spot. Because of the young ages of the grains and hence the low count rate, ${ }^{206} \mathrm{~Pb}$ was counted for 20 or 30 seconds across 5 or 6 scans to improve the counting statistics. Concentration standards used were MAD (Madagascar green: Barth and Wooden, 2010) at SUMAC and SL13 at ANU. Age standards were R33 (419 Ma, at SUMAC) and Temora (417 Ma, at ANU) (Black et al., 2004).

Since the zircon/melt partition coefficient is higher for $U$ than for Th, an initial deficit of ${ }^{230} \mathrm{Th}$ occurs in zircon during crystallisation, thus creating a temporal gap in the ${ }^{230} \mathrm{Th} /{ }^{234} \mathrm{U}$ secular equilibrium of the ${ }^{238} \mathrm{U}$ decay chain and hence an underestimation of the true age of zircon crystallisation. Using the observed Th and $U$ concentrations derived from the SIMS measurement, and a whole whole-rock Th/U value of 4.4 (Wilson and Charlier, 2009) a correction factor was applied using $\mathrm{f}=\left(\mathrm{Th} / \mathrm{U}_{\text {zir }}\right) /\left(\mathrm{Th} / \mathrm{U}_{\text {magma }}\right)$ (Schärer, 1984). Due to the young ages of the zircons, the data obtained are very susceptible to contamination by common $\mathrm{Pb}$. The presence of common $\mathrm{Pb}$ was evaluated by monitoring for ${ }^{204} \mathrm{~Pb}$ and ${ }^{207} \mathrm{~Pb} /{ }^{206} \mathrm{~Pb}$, and a 
correction was then applied using the recorded ${ }^{207} \mathrm{~Pb} /{ }^{206} \mathrm{~Pb}$ values and a common $\mathrm{Pb}$ isotopic composition $\left({ }^{207} \mathrm{~Pb} /{ }^{206} \mathrm{~Pb}=0.836\right)$ for the sample age from the average crust model of Stacey and Kramers (1975).

The samples varied widely in the proportion of ${ }^{206} \mathrm{~Pb}$ attributable to common $\mathrm{Pb}$, but all examples defined common- $\mathrm{Pb}$ mixing lines on inverse isochron diagrams with a $\mathrm{y}$-axis intercept within uncertainty of 4.55 Gyr. Samples from the Onepu Formation and Caxton Formation rhyolites (Table 2.2) typically had tens of percent of the ${ }^{206} \mathrm{~Pb}$ attributable to common $\mathrm{Pb}$, and analyses with $>70 \%$ common $\mathrm{Pb}$ were excluded from the data set. In older samples, a lower cut-off of 50,30 or $20 \%$ was used to exclude analyses with sometimes plausible, but imprecise ages from consideration. The values concerned for specific samples and grains are given in Electronic Appendix 4, and summarised in the relevant figure captions. We do not think that the high proportions of ${ }^{206} \mathrm{~Pb}$ attributable to common- $\mathrm{Pb}$ are reflecting hydrothermal alteration. The crystals are pristine in reflected light and CL imagery, and with euhedral crystal morphologies (see Fig. 2.13). Examples of zircons that CJNW has dealt with that have been altered (by fluids rich in $\mathrm{Ca}$ and $\mathrm{S}$ in the hydrothermal system at Raoul Island: Graaf, 2006) are partly anhedral, and show distinctive breakdown and replacement textures, matched by crystals in the experimental studies of Harlov and Dunkley (2010). In addition, there is controversy over $\mathrm{U}-\mathrm{Pb}$ age determinations from zircons with particularly high uranium concentrations, due to possible effects of the high $U$ values on the zircon crystal matrix, either through radiation damage, or through affecting the secondary ion yield (see White and Ireland, 2012). We saw no systematic age biases due to matrix effects in zircons with $\mathrm{U}$ values up to $8000 \mathrm{ppm}$ (with Th $=20100 \mathrm{ppm}$ ), and the high $\mathrm{U}$ zones $/$ crystals did not show any cracks usually associated with expansion due to metamictisation. The full $\mathrm{U}-\mathrm{Pb}$ age data set (including analyses eliminated due to high common- $\mathrm{Pb}$ ) is presented in Electronic Appendix 4.

\section{$2.5 \quad$ RESULTS}

The age data are presented below in order of decreasing age and grouped according to the host formations summarised in Table 2.1 and detailed in Milicich et al. (2013b). Age data are discussed from oldest to youngest, grouped within formations that can be petrographically recognised and correlated between several or, occasionally, all of the wells in the field. Individual zircon ages determined by single-crystal SIMS techniques are interpreted to represent a crystallisation age, not necessarily an eruption age. In addition the spectra obtained from multiple zircon grains from a single sample tend to show a peak distribution (typically 
estimated using the probability density function (pdf) generated in Isoplot: Ludwig, 2008) that often predates the eruption age by some tens of thousands of years (Simon et al., 2008), although differences between the peak of the pdf curve and eruption ages may also in part reflect the precision of the individual age determinations (Wilson and Charlier, 2009). For this paper, we estimate eruption ages by obtaining the weighted average of (in general) the ten youngest viable ages, using as a calibration the ages of three units, at $\sim 1.0 \mathrm{Ma}, 0.56 \mathrm{Ma}$ and $0.14 \mathrm{Ma}$ that have been independently dated by ${ }^{40} \mathrm{Ar} /{ }^{39} \mathrm{Ar}$ methods (see relevant sections below).

\subsubsection{Rotoroa and Waikora formations}

Deposition of the volcanic sequence at Kawerau is primarily controlled by downfaulting of the greywacke basement, with the depth to basement increasing from -667 mRL (meters relative to sea level) in the southeast (drillhole KA29) to $-1285 \mathrm{mRL}$ (KA48) in the northeast. The accommodation provided by this faulting allowed a thick infill of greywacke gravels (the Waikora Formation of Grindley and Browne, 1968) to be deposited in the north and northeast sectors of the field. These gravels thin to the southwest and are coeval with the Rotoroa Formation, which consists dominantly of fine-grained sediments (sands, silts). The earliest recognisable volcanic units consist of unwelded ignimbrites and other tuffaceous units incorporated within sediments and inferred palaeosols of the Rotoroa Formation, or within Waikora Formation gravels. These volcanic units tend to be more common and thicker in the Rotoroa Formation, presumably because of the more favourable preservation conditions. The thickest $(110 \mathrm{~m})$ is found from -735 to $-845 \mathrm{mRL}$ in drillhole KA41, and lies directly on Waikora Formation gravels.

Two samples were collected from core material from the deepest recognisable individual units: KATY824 (KA25, -796 mRL) and SA740 (KA34, -707 mRL) from KA34 (Fig. 2.2). Both are unwelded ignimbrites, but with different lithologies and no correlation was inferred from petrographic evidence. Both samples return simple, unimodal age spectra (Fig. 2.4) that predate any known TVZ eruptive units (Houghton et al., 1995). They are also significantly older than any other units penetrated in TVZ geothermal fields (Wilson et al., 2010). Sample SA740 has a weighted average age from the ten youngest viable age determinations of $2.38 \pm$ $0.05 \mathrm{Ma}$ and KATY824 a weighted average of $2.17 \pm 0.05 \mathrm{Ma}$. Fall deposit equivalents to these ignimbrites are likely to be represented by a burst of rhyolitic tephra deposition between 2.0 and 2.5 Ma recorded in offshore marine cores (Carter et al., 2003, 2004; Allan et al., 2008). Briggs et al. (2005) report ages of volcanic units in the southern Coromandel-Kaimai area 
some $80 \mathrm{~km}$ northwest of Kawerau that cover this time interval (Fig. 2.1). The Lower Papamoa Ignimbrite returned a plateau ${ }^{40} \mathrm{Ar} /{ }^{39} \mathrm{Ar}$ age of $2.40 \pm 0.02 \mathrm{Ma}$ that suggests a possible correlation by age with the unit sampled as SA740. Sample KATY824 contains abundant altered ferromagnesian minerals, which is consistent with the petrographic characteristics of rhyolite domes in the $1.90-2.69$ Ma Mangatawa Group of Briggs et al. (2005).

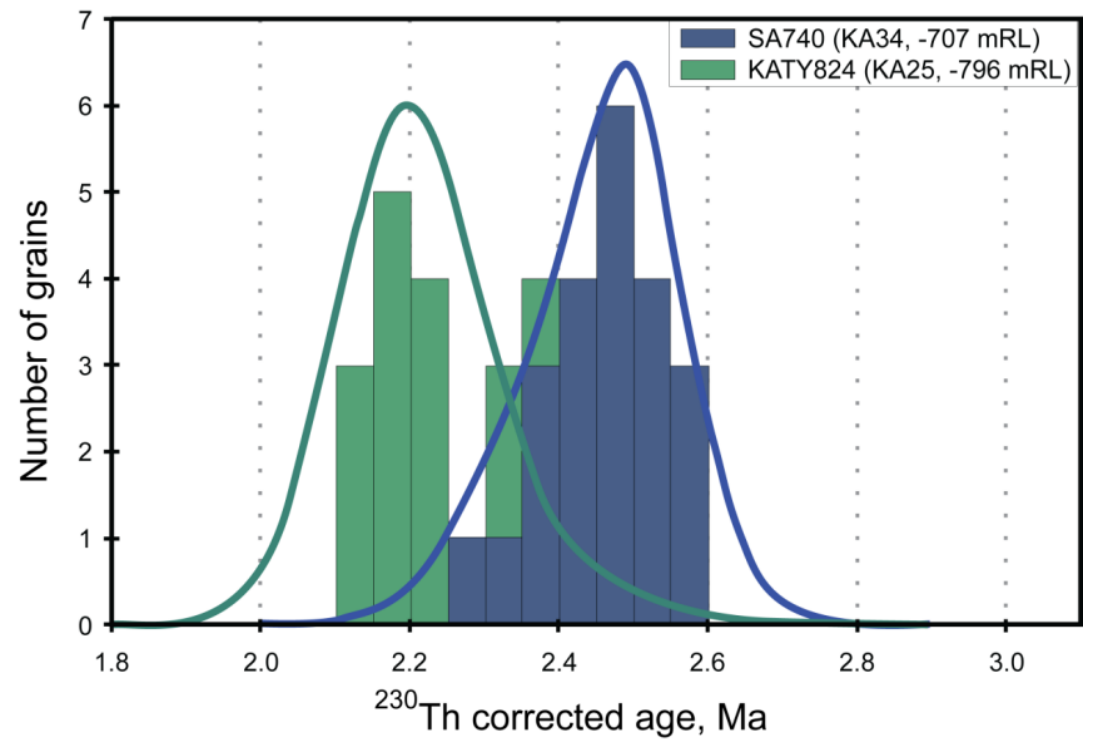

Figure 2.4 Histogram and relative probabilities (given by the probability density function in Isoplot: Ludwig, 2008) for samples SA740 ( $\mathrm{n}=22$, omitting two grains with $>8 \%$ common-Pb) and KATY824 ( $\mathrm{n}$ $=13$, omitting two grains with $>30 \%$ common $\mathrm{Pb}$ ) from ignimbrites within the Rotoroa Formation (mRL; meters relative to sea level). See Electronic Appendix 4 for full sample data.

The accommodation basins infilled by the greywacke gravels are inferred to be related to strike-slip faulting, rather than normal faulting because the relatively uniform thickness of succeeding ignimbrites of the Te Teko Formation. This implies a lack of significant topographic relief by $1.5 \mathrm{Ma}$. Detailed aeromagnetic data from the western margin of the Kaingaroa Plateau are interpreted by Downs et al. (2013a) to suggest that north nothweststriking faults cutting the basement greywacke (and predating the ignimbrite cover and hence plausibly correlative with the structures at Kawerau) occur there and have been re-activated by modern TVZ-related rifting.

\subsubsection{Te Teko Formation}

Overlying the sediment-dominated sequences resting on greywacke is a sequence between 0 and $250 \mathrm{~m}$ thick that is dominated by one partially-welded ignimbrite, though in some drillholes the corresponding sequence incorporates several welded to non-welded zones. This sequence rests on a weathering horizon, and is separated from the overlying ignimbrite- 
dominated sequence of the Raepahu Formation by a major palaeosol or sediments (Tasman Formation). Earlier stratigraphic models for the field (e.g. Grindley, 1986) had named various units as Te Teko and Opunoke ignimbrites, but detailed petrographic and stratigraphic correlations (Milicich et al., 2013b, and unpublished data) show that these terms have been applied incorrectly to the same unit in different wells, and the same name applied to petrographically distinct units in adjacent wells.

Table 2.3 Summary of age parameters for ignimbrites of the Te Teko Formation.

\begin{tabular}{|c|c|c|c|c|c|c|c|c|c|c|c|}
\hline \multirow[t]{3}{*}{ Sample } & \multicolumn{4}{|c|}{ Youngest age determinations } & \multirow{3}{*}{$\begin{array}{l}\text { Number of } \\
\text { spots/grains }\end{array}$} & \multicolumn{5}{|c|}{ All viable age determinations } & \multirow{3}{*}{$\begin{array}{l}\text { Peak of } \\
\text { pdf curve } \\
(\mathrm{Ma})\end{array}$} \\
\hline & Age & 2 s.d. & MSWD & Probability & & Age & 2 s.d. & MSWD & Probability & spots/grains & \\
\hline & $(\mathrm{Ma})$ & $(\mathrm{Ma})$ & & & & (Ma) & (Ma) & & & & \\
\hline KA23_1 & 1.34 & 0.04 & 0.36 & 0.96 & 10 & 1.5 & 0.03 & 3.7 & 0 & 56 & 1.52 \\
\hline SALLY576 & 1.47 & 0.03 & 0.68 & 0.69 & 8 & 1.56 & 0.1 & 17 & 0 & 18 & 1.48 \\
\hline DE608 & 1.45 & 0.03 & 0.25 & 0.99 & 10 & 1.55 & 0.03 & 3 & 0 & 49 & 1.52 \\
\hline DA705 & 1.48 & 0.03 & 0.79 & 0.62 & 10 & 1.56 & 0.03 & 3.5 & 0 & 25 & 1.53 \\
\hline BOB822 & 1.46 & 0.03 & 0.88 & 0.53 & 8 & 1.51 & 0.03 & 3.2 & 0 & 15 & 1.47 \\
\hline ST906 & 1.45 & 0.03 & 0.52 & 0.86 & 10 & 1.54 & 0.01 & 1.7 & 0 & 50 & 1.53 \\
\hline AN1101 & 1.44 & 0.04 & 0.102 & 1 & 10 & 1.56 & 0.03 & 3.7 & 0 & 49 & 1.54 \\
\hline Ave (6) & 1.46 & 0.01 & 0.42 & 1 & 56 & 1.54 & 0.01 & 2.2 & 0 & 206 & 1.52 \\
\hline
\end{tabular}

a Averages derived from data for all samples except KA23_1. The mean and uncertainty values for all viable age determinations utilises the reject OK?' option in Isoplot to eliminate older outliers.

Seven samples were taken from the Te Teko Formation in six wells where the deposits were best expressed and core available (Table 2.2). Petrographic descriptions and age data (Fig. 2.5) imply that across most of the field, the Te Teko Formation is represented by only one distinguishable ignimbrite. Age data from six of the seven samples are identical within analytical uncertainty, and are inferred to represent a single ignimbrite (which could, however be a compound cooling unit, on the basis of variable degrees of welding) with an age of 1.46 $\pm 0.01 \mathrm{Ma}$ on the weighted means of the youngest $8-10$ ages from each sample (Table 2.3). In drillhole KA23, however, two ignimbrites are present, separated by $25 \mathrm{~m}$ of sediments and/or palaeosols (Fig. 2.3). The upper ignimbrite returns a different age estimate of $1.34 \pm$ $0.04 \mathrm{Ma}$ on the basis of the youngest 10 age determinations, consistent with it being a distinctive, younger deposit which, however, has been identified only in drillholes KA23, KA45 and KA46 (Fig. 2.2). We infer on the basis of the overall average and pdf peak for the zircon population analysed that many of the zircons in this younger unit may be derived from the older deposits, either from magmatic inheritance or incorporation of xenocrysts or lithic fragments in the tuff. 


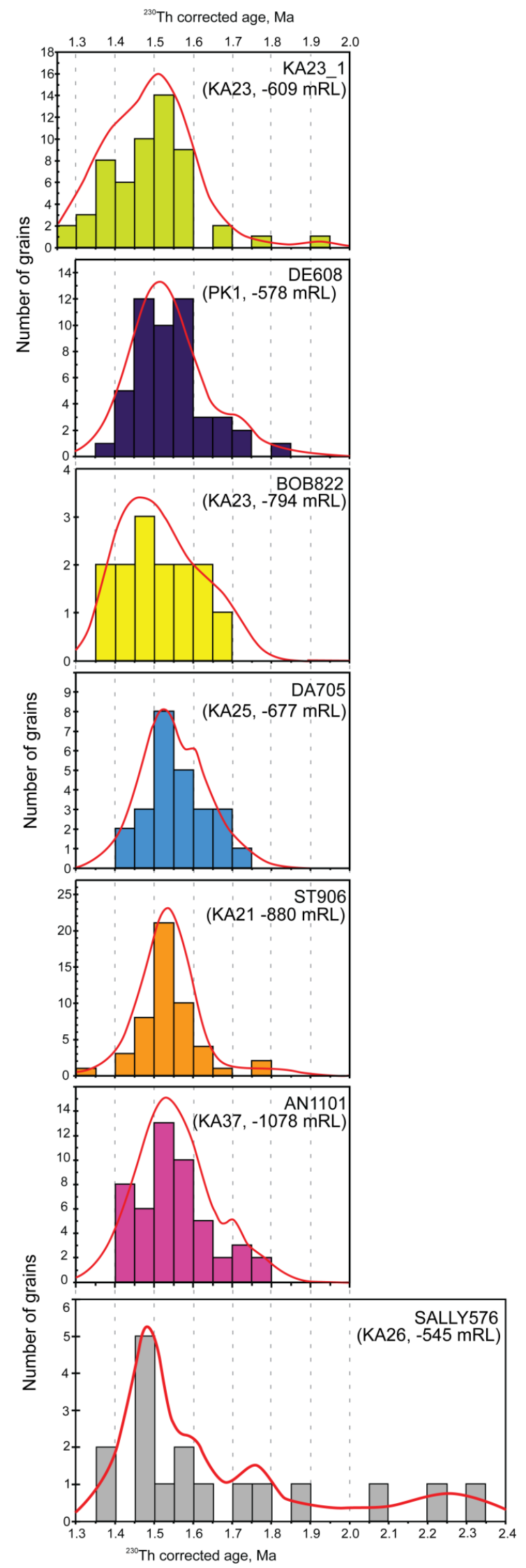

Figure 2.5 Histogram and relative probabilities (given by the probability density function in Isoplot: Ludwig, 2008) for samples SALLY576 $(n=18), \operatorname{DE} 608(n=49), \operatorname{KA} 23-1 \quad(n=58), \operatorname{BOB} 822(n=15)$, DA705 $(n=25)$, ST906 $(n=50)$ and AN1101 $(n=49)$ from samples in the Te Teko Formation. In all cases, grains with $>20 \%$ common-Pb were omitted. See Electronic Appendix 4 for full sample data. 


\subsubsection{Raepahu Formation}

The Raepahu Formation (Edbrooke, 2005) was defined as a mapping term for surficial deposits of two major eruptions; the Kidnappers fall deposit and ignimbrite (Wilson et al. 1995b; Cooper et al., 2012), and the Rocky Hill ignimbrite (Martin, 1961), both of which are exposed together west of the TVZ. These two deposits have ${ }^{40} \mathrm{Ar} /{ }^{39} \mathrm{Ar}$ ages that overlap within uncertainty around $1 \mathrm{Ma}$ (Houghton et al., 1995; Wilson et al., 1995b), but are inferred to represent separate eruptions, based on field evidence for an intervening short-lived period of erosion (Wilson, 1986).

The lateral equivalent of the Raepahu Formation at Kawerau is inferred to be a series of ignimbrites with $\mathrm{U}-\mathrm{Pb}$ ages clustered around 1.0 Ma. These predominantly occur beneath the (un-dated) Kawerau Andesite, but also below sediments of the Onerahi Formation. Three samples have been dated from this formation; all return age estimates based on the youngest 10 grains or all the age determinations that overlap within $1-2$ standard deviation (s.d.) uncertainties and are indistinguishable on age grounds alone (Table 2.4). On the basis of a similar age spectrum present in published and unpublished age data (Wilson et al., 2008; Table 2.4; Fig. 2.6) and the occurrence of altered biotite in the crystal fraction, sample KA23_2 (KA23, $-426 \mathrm{mRL}$ ) is correlated with the Kidnappers ignimbrite. The Kidnappers ignimbrite is of limited extent within the Kawerau Field, occurring only in KA23, KA45, KA46 and KA30 (Fig. 2.2), suggesting the contemporaneous presence of some local topographic relief to channel its deposition or perhaps through differential erosion. The source of this ignimbrite is inferred to be the Mangakino Caldera. The earlier ignimbrite, sampled as BRUCE457 (KA26, $426 \mathrm{mRL}$ ) and AI780 (KA48, -747 mRL) has age characteristics that are the same within uncertainties (Table 2.4), but is differentiated on the basis of petrography. This earlier ignimbrite is widespread across the field, suggesting that it spread across an area of limited topographic relief. The source of this unit and its relationship with the Kidnappers ignimbrite is unknown. 
Table 2.4 Summary of age parameters for ignimbrites of the Raepahu Formation.

\begin{tabular}{|c|c|c|c|c|c|c|c|c|c|c|c|}
\hline \multirow[t]{2}{*}{ Sample } & \multicolumn{4}{|c|}{ Youngest age determinations } & \multirow{2}{*}{$\begin{array}{l}\text { Number of } \\
\text { spots/grains }\end{array}$} & \multicolumn{4}{|c|}{ All viable age determinations } & \multirow{2}{*}{$\begin{array}{l}\text { Number of } \\
\text { spots/grains }\end{array}$} & \multirow{2}{*}{$\begin{array}{l}\text { Peak of } \\
\text { pdf curve } \\
(\mathrm{Ma})\end{array}$} \\
\hline & $\begin{array}{l}\text { Age } \\
(\mathrm{Ma})\end{array}$ & $\begin{array}{l}2 \text { s.d. } \\
(\mathrm{Ma})\end{array}$ & MSWD & Probability & & $\begin{array}{l}\text { Age } \\
(\mathrm{Ma})\end{array}$ & $\begin{array}{l}2 \text { s.d. } \\
(\mathrm{Ma})\end{array}$ & MSWD & Probability & & \\
\hline KA23_2 & 0.95 & 0.05 & 0.27 & 0.98 & 10 & 1.1 & 0.03 & 3 & 0 & 38 & 1.1 \\
\hline BRUCE457 & 0.98 & 0.04 & 0.33 & 0.96 & 10 & 1.05 & 0.03 & 1.5 & 0.04 & 27 & 1.04 \\
\hline AI780 & 1 & 0.03 & 0.25 & 0.99 & 10 & 1.07 & 0.03 & 2.6 & 0 & 26 & 1.04 \\
\hline P1722a & 1.03 & 0.03 & 0.41 & 0.93 & 10 & 1.12 & 0.02 & 2.8 & 0 & 41 & 1.11 \\
\hline P2006 & 0.96 & 0.03 & 0.25 & 0.99 & 10 & 1.06 & 0.03 & 7.4 & 0 & 59 & 1.03 \\
\hline P2008a & 0.97 & 0.03 & 0.12 & 1 & 10 & 1.03 & 0.02 & 1.7 & 0 & 45 & 0.99 \\
\hline
\end{tabular}

${ }^{a}$ Age data from three individual pumices collected from the Kidnappers ignimbrite at a pumice pit at NZMS $100 \mathrm{~m}$ grid reference T15/588400. Data from clast P1722 published in Wilson et al. (2008); data from P2006 and P2008 are unpublished.

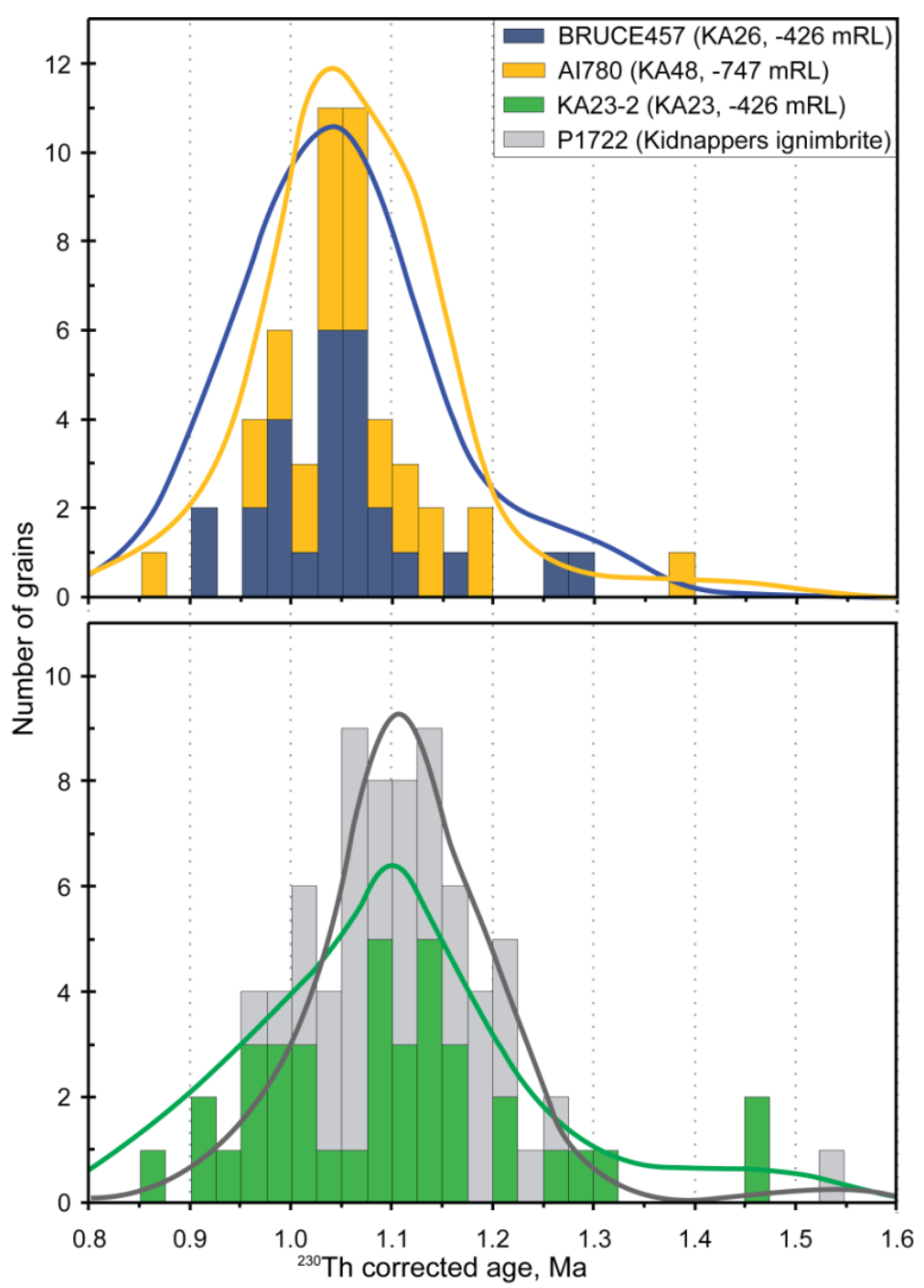

Figure 2.6 Histogram and relative probabilities (given by the probability density function in Isoplot: Ludwig, 2008) for samples BRUCE457 $(n=27), \operatorname{AI780}(n=26), \mathrm{KA} 23-2(n=39)$ and P1722 (Kidnappers Ignimbrite; $n=37$ ) comparing samples within the Raepahu Formation with a surficial sample of Kidnappers ignimbrite (data from Wilson et al., 2008). In all cases, grains with $>20 \%$ common$\mathrm{Pb}$ were omitted. See Electronic Appendix 4 for full sample data. 


\subsubsection{Karaponga Formation}

Across much of the Kawerau Field, there is a distinctive unit of intermediate composition, the Kawerau Andesite, which is inferred from textural evidence and the presence of marginal breccias to represent a composite pile of lava flows (Bogie, 1981). The source is inferred to be in the northwest part of the field, which magnetic surveys (MacDonald and Muffler, 1972) ascribe to an andesitic volcanic centre, although no inferred feeder structures have been intercepted in the geothermal drillholes (cf. rhyolites of the Caxton and Onepu formations, below). The Kawerau Andesite is overlain by a sequence of ignimbrites 0 to $180 \mathrm{~m}$ thick forming part of a package of volcanic deposits here termed the Karaponga Formation. Three samples were taken for age determinations (Table 2.2). In samples from this and younger formations the zircons had increasing proportions of ${ }^{206} \mathrm{~Pb}$ attributable to common- $\mathrm{Pb}$. For the Karaponga Formation samples a cut-off of $30 \%$ was used (Electronic Appendix 4) to remove analyses with potential accuracy problems associated with large common- $\mathrm{Pb}$ corrections.

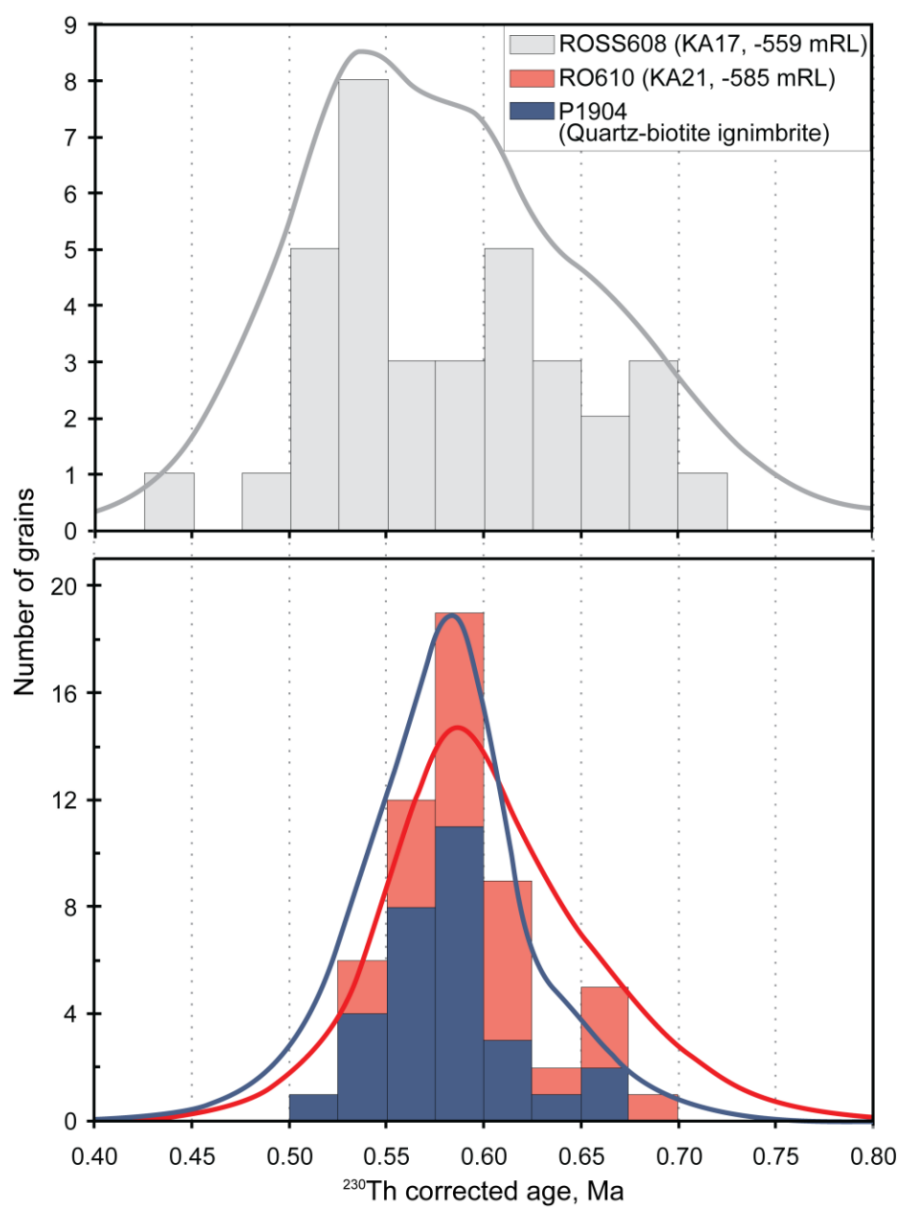

Figure 2.7 Histogram and relative probabilities (given by the probability density function in Isoplot: Ludwig, 2008) for samples ROSS608 ( $n=37)$, RO610 $(n=24)$ within the Karaponga Formation at Kawerau and P1904 $(n=30)$ which is from pumice in outwash fluvial sediments from the Quartzbiotite ignimbrite of Nairn (2002). In all cases, grains with $>30 \%$ common-Pb were omitted. See Electronic Appendix 4 for full sample data. 
The ignimbrites dated in this formation returned very clean spectra, with little inheritance (Table 2.5; Fig. 2.7). Sample ROSS608 (KA17, -559 mRL) has a peak in the pdf distribution at $0.54 \mathrm{Ma}$ and a weighted mean of the ten youngest grains of $0.51 \pm 0.02 \mathrm{Ma}$, while sample RO610 (KA21, -747 mRL) has a pdf peak at $0.59 \mathrm{Ma}$ and a weighted mean age from the youngest 10 grains of $0.57 \pm 0.02 \mathrm{Ma}$. We infer that these two units represent different eruptions. The oldest unit was sampled as KI495 (KA48, -477), but yielded a very sparse population of zircon grains, which have no single clear mode. The youngest 4 grains form a coherent group with a weighted mean age of $0.60 \pm 0.05 \mathrm{Ma}$, and this is our preferred eruption age estimate of the host protolith. The host rock to sample RO610 is distinctively crystal-rich, with large quartz crystals and relicts of biotite. The zircon CL textures and age spectrum from this sample closely match those from zircons extracted from crystal-rich, large-quartz and biotite-bearing pumices (P1904; Fig. 2.7) found in fluvial outwash deposits exposed on the Bay of Plenty coast (Hikuroa et al., 2006; Fig. 2.1). These outwash deposits are correlated on the basis of bracketing unpublished ${ }^{40} \mathrm{Ar} /{ }^{39} \mathrm{Ar}$ age data (G.S. Leonard and A.T. Calvert, pers. comm.) with a large ignimbrite (the Quartz-biotite Ignimbrite of Nairn, 2002; Cole et al., 2010) which has also independently been ${ }^{40} \mathrm{Ar} /{ }^{39} \mathrm{Ar}$ dated at $0.557 \pm 0.003 \mathrm{Ma}$ (Leonard et al., 2010).

\subsubsection{Tahuna Formation}

The Karaponga Formation is overlain by a 0 to $360 \mathrm{~m}$-thick sequence dominated by sedimentary units with intercalated tuffs of the Tahuna Formation. Three samples were taken from these tuffs (Table 2.2). All samples had moderate proportions of ${ }^{206} \mathrm{~Pb}$ attributable to common- $\mathrm{Pb}$, and a cut-off of 50\% generally was used (Electronic Appendix 4).

ALEXA415 (KA48, -397 mRL) and JOHN346 (KA22, -284 mRL) were sampled towards the top of the formation, while NICK547 (KA21, -521 mRL) was sampled from below the Caxton Formation. They have age spectra that are very similar, although there appears to be a tail towards older ages (Fig. 2.8). The weighted means of ages of the ten youngest grains from ALEXA415 and NICK547 overlap within error at $0.44 \pm 0.02 \mathrm{Ma}$, similar to the wholesample spectrum from the limited number of grains analysed from JOHN346 (Table 2.5). The similarity of these ages and the stratigraphic position of these tuffs around lava flows of the Caxton Formation suggest that the tuffs represent a clustering of rhyolitic pyroclastic activity, probably from local sources on the basis of the deposit thicknesses, prior to extrusion and intrusion of the Caxton Formation rhyolite. 
Table 2.5 Summary of age parameters for ignimbrites of the Karaponga and Tabuna formations.

\begin{tabular}{|c|c|c|c|c|c|c|c|c|c|c|c|}
\hline \multirow[t]{2}{*}{ Sample } & \multicolumn{4}{|c|}{ Youngest age determinations } & \multirow{2}{*}{$\begin{array}{l}\text { Number of } \\
\text { spots/grains }\end{array}$} & \multicolumn{4}{|c|}{ All viable age determinations } & \multirow{2}{*}{$\begin{array}{l}\text { Number of } \\
\text { spots/grains }\end{array}$} & \multirow{2}{*}{$\begin{array}{l}\text { Peak of } \\
\text { pdf curve } \\
(\mathrm{Ma})\end{array}$} \\
\hline & $\begin{array}{l}\text { Age } \\
(\mathrm{Ma})\end{array}$ & $\begin{array}{l}2 \text { s.d. } \\
(\mathrm{Ma})\end{array}$ & MSWD & Probability & & $\begin{array}{l}\text { Age } \\
(\mathrm{Ma})\end{array}$ & $\begin{array}{l}2 \text { s.d. } \\
(\mathrm{Ma})\end{array}$ & MSWD & Probability & & \\
\hline ROSS608 & 0.51 & 0.02 & 0.77 & 0.64 & 10 & 0.57 & 0.02 & 2 & 0 & $37(35)$ & 0.54 \\
\hline RO610 & 0.57 & 0.02 & 0.21 & 0.99 & 10 & 0.6 & 0.01 & 1.06 & 0.38 & $25(25)$ & 0.59 \\
\hline P1904 & 0.55 & 0.02 & 0.26 & 0.99 & 10 & 0.58 & 0.01 & 1.5 & 0.06 & $30(27)$ & 0.59 \\
\hline KI495 & 0.6 & 0.05 & 0.3 & 0.83 & 4 & 1.07 & 0.23 & 69 & 0 & $17(16)$ & 0.6 \\
\hline$J O H N 346^{b}$ & & & & & & 0.43 & 0.05 & 1.6 & 0.14 & $8(7)$ & 0.47 \\
\hline ALEXA415 & 0.43 & 0.03 & 0.2 & 0.99 & 10 & 0.51 & 0.03 & 4.8 & 0 & $39(33)$ & 0.47 \\
\hline NICK547 & 0.44 & 0.02 & 0.54 & 0.85 & 10 & 0.54 & 0.05 & 21 & 0 & $40(34)$ & 0.52 \\
\hline
\end{tabular}

${ }^{a}$ First number is the total of grains which yielded viable ages on the basis of acceptable common-Pb proportions (Electronic Appendix 4); number (in brackets) is those grains yielding the weighted mean age estimate quoted using the 'reject OK?' option in Isoplot. 'Insufficient age determinations to identify a 'youngest' age population

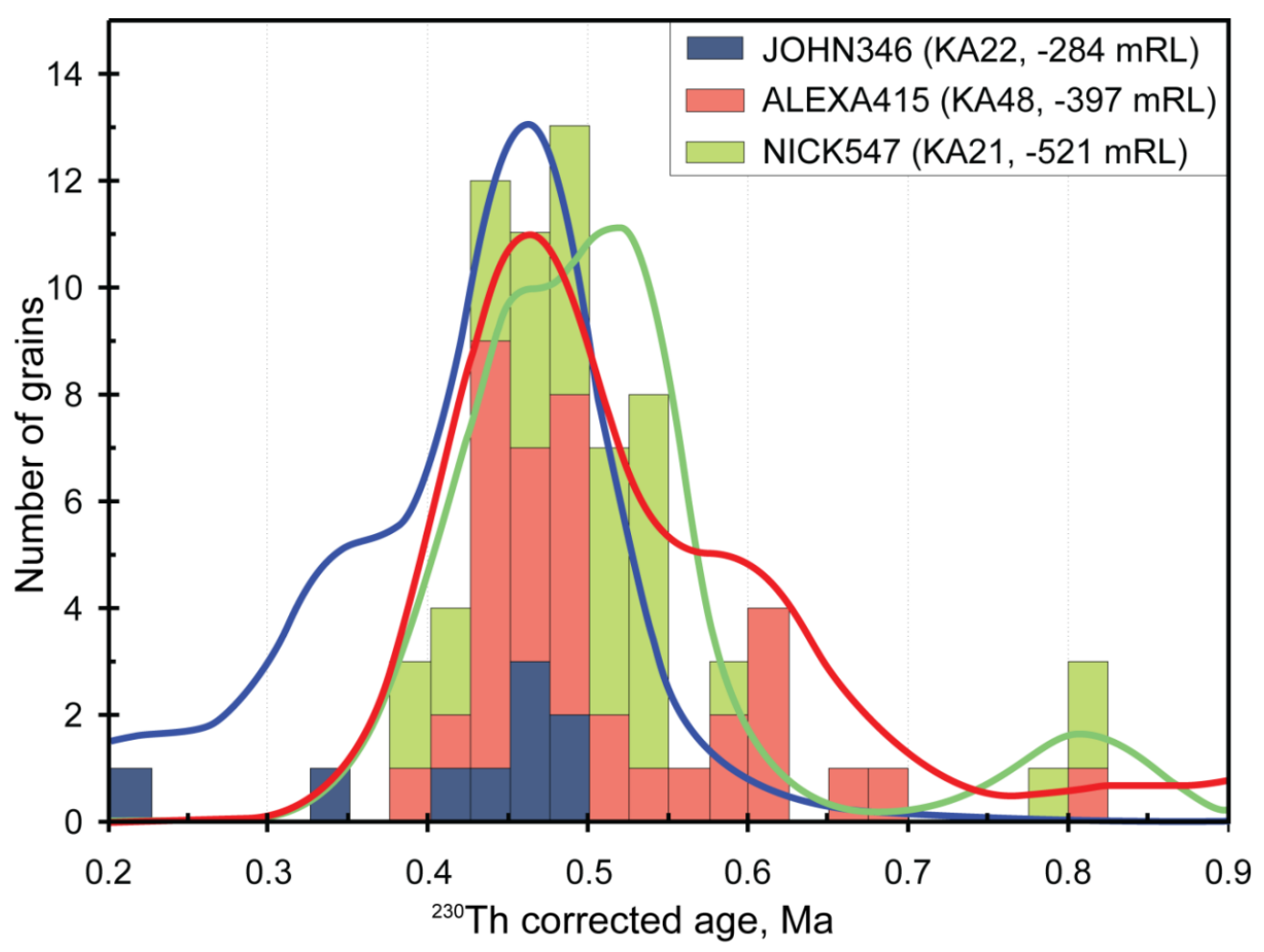

Figure 2.8 Histogram and relative probabilities (given by the probability density function in Isoplot: Ludwig, 2008) for samples JOHN346 $(n=9)$ ALEXA415 $(n=43)$ and NICK547 $(n=41)$ from tuffs within the Tahuna Formation. See Electronic Appendix 4 for full sample data. 


\subsubsection{Caxton Formation}

Numerous bodies of coherent rhyolite lying below the Matahina ignimbrite have been intersected by drillholes at Kawerau, with one to three bodies in individual wells. There is a consistent zone of coherent rhyolite (up to $450 \mathrm{~m}$ thick) that lies just below the Matahina ignimbrite, and which was previously labelled as Onepu Rhyolite (e.g., Bignall and Harvey, 2005). Deeper, coherent rhyolite bodies where present, were referred to in different wells as the Caxton Rhyolite (Browne, 1978a; Grindley, 1986), and had been inferred to be extruded from multiple vents, forming a large rhyolite complex interbedded with Kawerau Andesite and ignimbrite units, and hence of widely differing age characteristics. Two distinct petrographic types, moderately crystal-rich ( $\sim 15$ volume $\%$, fractured quartz, plagioclase, apatite) and crystal-poor ( $\sim 5$ volume $\%$, quartz, plagioclase, biotite, amphibole) were recognised within these two formally named units.

Detailed re-assessment of these lithologies (Milicich et al., 2013b) combined with the new age data presented here reveal that all these units are of closely similar age (Table 2.6). Almost all samples contained significant amounts of $\mathrm{Pb}$ attributable to common- $\mathrm{Pb}$ (Electronic Appendix 4) and a cut-off of 70\% was used. Samples GR295 (PK5, -275 mRL) and FR443 (KA21, -418 mRL) represent a slightly younger crystal-poor extrusive, while MI678 (KA36, $655 \mathrm{mRL}$ ) and SI967 (KA36, -944) are deeper crystal-poor intrusive equivalents (Fig. 2.9). BI459 (KA17, -408 mRL) is from a slightly older (demonstrable from field relationships as it sits beneath the crystal-poor extrusive in KA17: Fig. 2.3), moderately crystal-rich rhyolite breccia, inferred to be from the margin of a dome extrusion. Samples JE656 (KA28, -631 $\mathrm{mRL})$ and JO1016 (KA28, -991 mRL) are interpreted to represent the intrusive equivalent of this unit (Fig. 2.9). The moderately crystal-rich rhyolite is much less extensive, occurring only in the northwest part of the field. The age determinations from all these units mostly overlap within uncertainties, but some samples (especially JE656) appear to have inherited significant numbers of older grains. The best estimates for eruption ages based on the youngest 10 viable ages are identical within error, at $0.36 \pm 0.03 \mathrm{Ma}$ for the crystal-poorer and $0.36 \pm 0.02 \mathrm{Ma}$ for the crystal-richer rhyolite (Table 2.6). 
Table 2.6 Summary of age parameters for coherent rhyolite units of the Caxton Formation.

\begin{tabular}{|c|c|c|c|c|c|c|c|c|c|c|c|c|}
\hline \multirow[t]{3}{*}{ Sample } & \multirow[t]{3}{*}{ Code $^{a}$} & \multicolumn{4}{|c|}{ Youngest age determinations } & \multirow{3}{*}{$\begin{array}{l}\text { Number of } \\
\text { spots/grains }\end{array}$} & \multicolumn{5}{|c|}{ All viable age determinations } & \multirow{3}{*}{$\begin{array}{l}\text { Peak of } \\
\text { pdf curve } \\
(\mathrm{Ma})\end{array}$} \\
\hline & & Age & 2 s.d. & MSWD & Probability & & Age & 2 s.d. & MSWD & Probability & spots/grains & \\
\hline & & $(\mathrm{Ma})$ & $(\mathrm{Ma})$ & & & & (Ma) & (Ma) & & & & \\
\hline GR295b & PE & - & - & - & - & - & 0.54 & 0.17 & 5.5 & 0 & 7 & $\mathrm{n} / \mathrm{a}$ \\
\hline FR443 ${ }^{\mathrm{b}}$ & PE & - & - & - & - & - & 0.41 & 0.04 & 1.2 & 0.33 & 7 & $\mathrm{n} / \mathrm{a}$ \\
\hline MI678 & PI & 0.41 & 0.03 & 1.4 & 0.17 & 10 & 0.44 & 0.04 & 4.6 & 0 & 15 & 0.43 \\
\hline SI967b & PI & - & - & - & - & - & 0.42 & 0.04 & 1 & 0.44 & 10 & 0.41 \\
\hline all & $P E, P I$ & 0.36 & 0.03 & 0.38 & 0.95 & 10 & & & & & 39 & 0.42 \\
\hline BI459c & RE & 0.42 & 0.02 & 0.18 & 1 & 10 & 0.47 & 0.02 & 2.2 & 0 & 30 & 0.43 \\
\hline JE656 & RI & 0.42 & 0.03 & 0.82 & 0.59 & 10 & 0.52 & 0.04 & 7.9 & 0 & 29 & 0.54 \\
\hline JO1016 & RI & $0.37^{\mathrm{b}}$ & 0.02 & 0.35 & 0.96 & 10 & 0.44 & 0.04 & 8.7 & 0 & 29 & 0.38 \\
\hline all & RE, $R I$ & 0.36 & 0.02 & 0.02 & 1 & 10 & & & & & 88 & \\
\hline
\end{tabular}

${ }^{\mathrm{a}} \mathrm{P}=$ crystal-poorer $(\sim 5 \%) ; \mathrm{R}=$ crystal-richer $(\sim 15 \%) ; \mathrm{E}=$ inferred extrusive rock; $\mathrm{I}=$ inferred intrusive rock 'Insufficient age determinations to identify a 'youngest' age population

'Excludes anomalous age determination of $0.28 \pm 0.05 \mathrm{Ma}$ from one grain (see Electronic Appendix 4) 


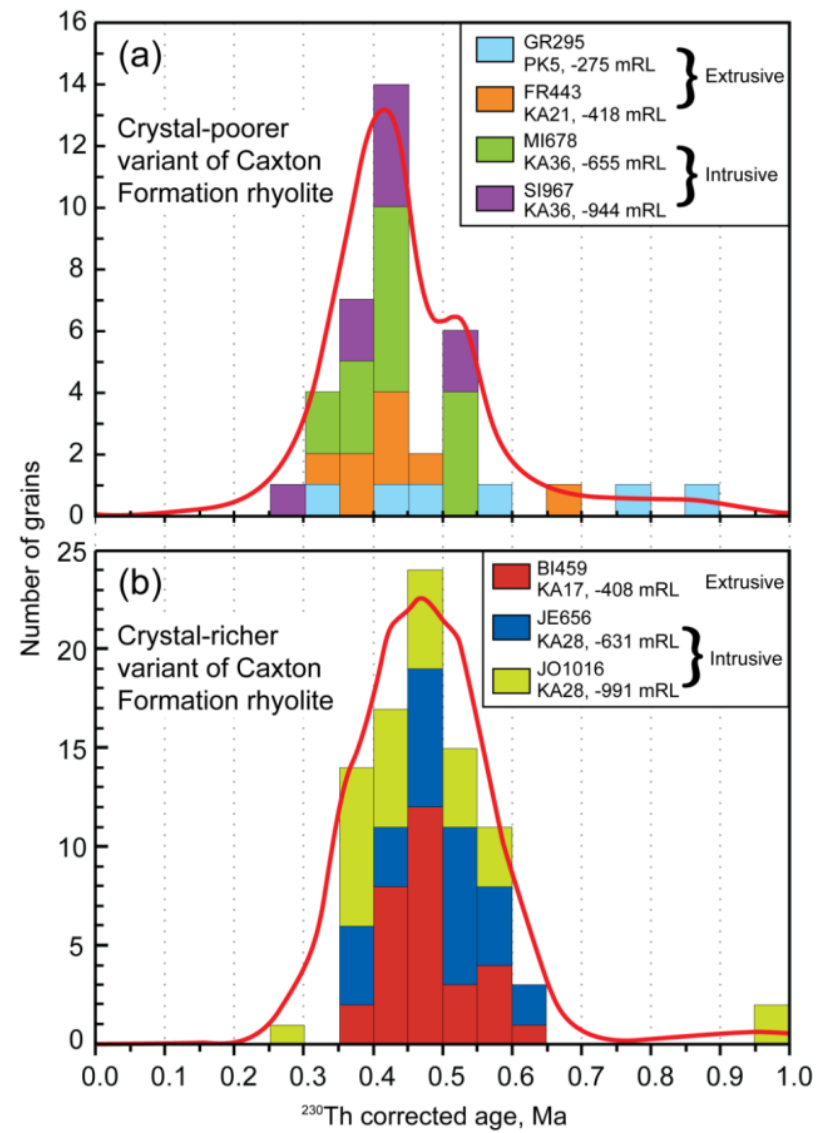

Figure 2.9 Stacked histograms for all samples labelled as Caxton Formation rhyolite, grouped into (a) crystalpoorer $(\sim 5 \%)$ and (b) crystal-richer variants (Table 2.6). See Electronic Appendix 4 for full sample data

\subsubsection{Onepu Formation}

As part of our study, a sample of sub-surface coherent rhyolite (JA885; KA30, -845 mRL) that had been sampled as part of the previously described Caxton Formation material yielded an unexpectedly younger $\mathrm{U}-\mathrm{Pb}$ age spectrum. To test the possibility that part of the subsurface feeder structure to the surficial Onepu domes had been intersected, zircons were analysed from Onepu dome material (D085) and a petrographically similar intrusive body (dike) intersected in core from drillhole PK8 at -2647 mRL (J2667) (Table 2.2). The age spectra from all three samples have moderate to high proportions of common- $\mathrm{Pb}$, and a cutoff at $70 \%$ was used as for the Caxton Formation rhyolites. However, the three Onepu Formation samples are clearly similar (Fig. 2.10) in their younger values, and with a tail of older ages back to $0.50-0.55 \mathrm{Ma}$. The weighted mean of the ten youngest ages (Electronic Appendix 4) from all three samples combined is $0.15 \pm 0.01 \mathrm{Ma}$, closely comparable to the ${ }^{40} \mathrm{Ar} /{ }^{39} \mathrm{Ar}$ age on the dome material of $0.138 \pm 0.007 \mathrm{Ma}$. 


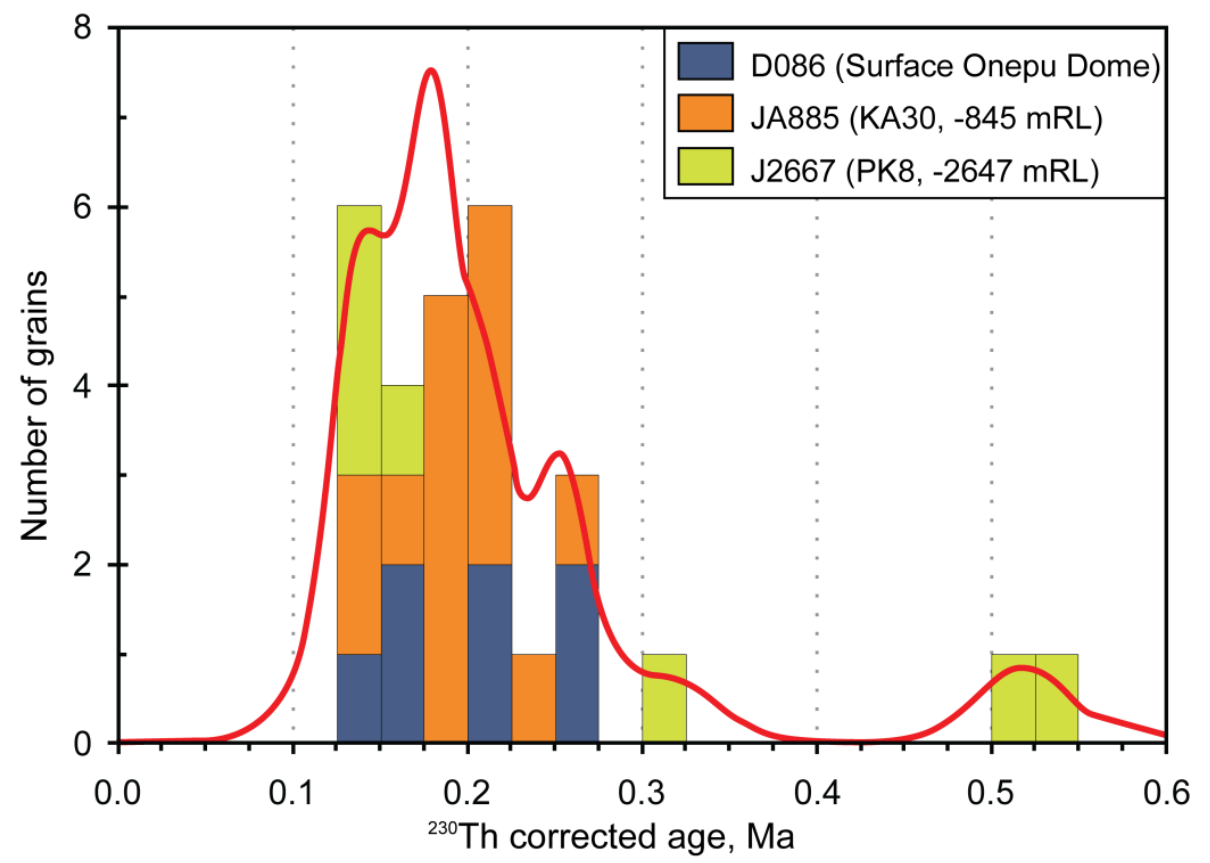

Figure 2.10 Age data for zircons from two samples (JA885; J2667) inferred to be from the subsurface feeder to the surficial Onepu dome rhyodacite (D068) with stacked histograms and overall PDF curve for all analysed grains with $<70 \%$ common $\mathrm{Pb}$. See Electronic Appendix 4 for full sample data.

\subsection{DISCUSSION}

Although this paper is primarily focused on presenting the new age data as a framework for the detailed investigation of stratigraphy and structure of the Kawerau Field in Milicich et al. (2013b), it is important to recognize the effects of the overall re-dating on field stratigraphy previously used. Fig. 2.11 presents an example cross section of the field from Bignall and Harvey (2005) and compares it with that derived from our work. Apart from adding age estimates to all the key units, our work has clarified the previously confused situation with respect to the early ignimbrites inconsistently labelled as Opunoke and Te Teko ignimbrites, and the presence at multiple stratigraphic levels of the Caxton and Onepu rhyolites. 

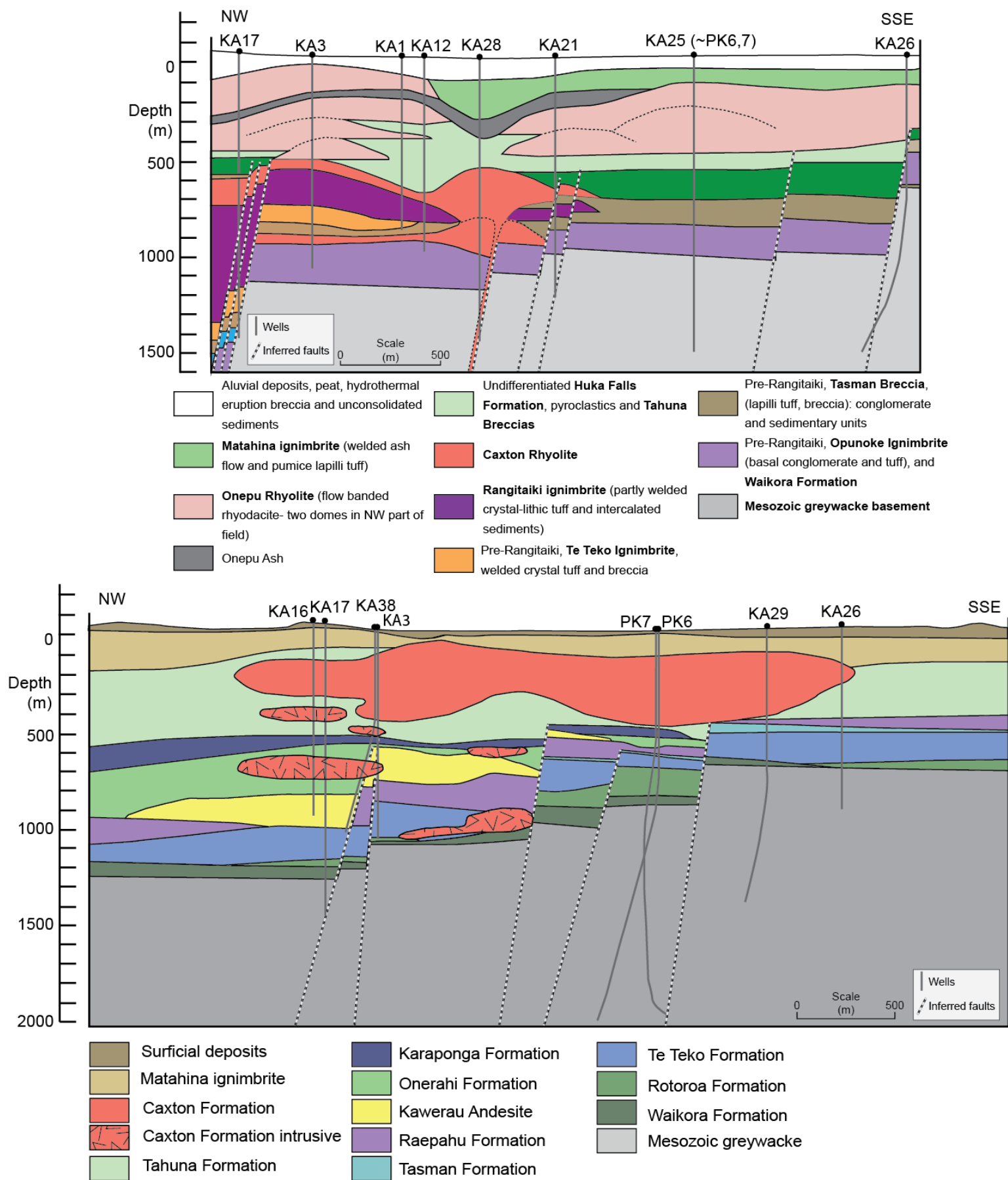

Figure 2.11 Cross sections from northwest to south southeast across the Kawerau Geothermal Field (cross section line is indicated in Fig. 2.2). The upper section is from the geology presented in Bignall and Harvey (2005) and represents the understanding of the field up to that point. The section below is the new stratigraphy interpreted in light of the dates presented in this paper. All wells in both sections are projected onto the section.

\subsubsection{Sampling of altered rocks in geothermal systems}

A challenge in undertaking age determinations on zircons from geothermal field samples is that the crystals are separated from whole-rock tuff or cuttings, and there is thus opportunity for contamination by both older and younger grains. Older material may have been introduced via xenolithic or xenocrystic material in the tuffs themselves, whereas contamination of 
younger material in cuttings may have happened via downhole mixing from overlying material. Despite this, admixture of older grains has not been a significant issue in this study. Where cuttings were used, they were selected from directly below well casing points to limit downhole contamination, or beneath a distinctive unit so the presence of contamination would be more obvious. Where cuttings have been used, the contamination, perhaps surprisingly, overwhelmingly tends to be of older grains. Our interpretation of this is that the major source of mixing comes from overlying fluvial sediments which not only are likely to be weakly coherent and liable to disintegration, but also will contain a representation of all the earlier zircon-bearing lithologies in the catchment drained by streams that passed through the Kawerau area. In samples from coherent rhyolite (Caxton and Onepu Formations), the presence of numerous older grains (e.g., JE656; KA28, -631 mRL) can be inferred to indicate that the source magma incorporated older grains from an earlier period of local magmatism, as the rocks concerned are intruding lithologies older than the possible contaminant, and are coherent rhyolite, rather than tuff.

\subsubsection{Local magmatism at Kawerau versus distal volcanism}

Within the area encompassed by the Kawerau Geothermal Field the record of volcanic and shallow intrusive rocks sampled for this study show a contrast in genesis and setting that is important in determining the thermal history of the field. Most of the tuff units sampled represent ignimbrites that were demonstrably (e.g. Kidnappers ignimbrite) or probably erupted from sources well outside the margins of the field. These units are valuable as timeplane markers for inferring the contemporaneous local topographic relief and displacement timings across fault planes (Milicich et al., 2013b), but have no relevance to underlying magmatic sources for hydrothermal activity in the Kawerau area. In contrast, there are three periods when it is clear that magma was present in the crust below the Kawerau area; at present, associated with the Holocene development of the Putauaki andesite composite cone and its underlying magmatic system as early as $\sim 9 \mathrm{ka}$ (Nairn and Wiradiradja, 1980); around $0.138 \mathrm{Ma}$ at the time of extrusion of the Onepu Formation rhyodacite domes, and at $\sim 0.36$ $\mathrm{Ma}$ at the time of the Caxton Formation rhyolite intrusions and extrusions.

Our age determinations thus imply that the modern geothermal system is a very young feature superimposed on an area that has experienced two previous occasions when magmatic activity directly underlay the area (i.e., that associated with the Caxton and Onepu rhyolites). A fourth possible period of underlying magmatism is possibly indicated by presence in the Caxton and Onepu formations and associated tuffs of persistent tails of zircon ages in the $0.55 \pm 0.05 \mathrm{Ma}$ 
range. These older grains cannot be interpreted solely as having been accidentally included from tuffs of that age intersected in the field because the host rocks include coherent rhyolite intrusions sampled at stratigraphic levels below the $0.5-0.6 \mathrm{Ma}$ tuffs. Although the presence of a hydrothermal eruption breccia in tuffs below the $0.36 \mathrm{Ma}$ Caxton Formation extrusives in KA25 was taken by Browne (1979) to indicate that the Kawerau system had been active at least since that time (albeit possibly fluctuating in intensity), our work suggests that this early activity reflects heat flow associated with the Caxton Formation rhyolites, and that there is no link to the heat source fuelling the modern system.

\subsubsection{Subsidence rates and tectonic processes at Kawerau}

The depths to which surficial eruptive units have been buried allow for first-order estimates of the net subsidence rates operating through time (e.g., Wilson et al., 2010). If the modern ground surface is taken as a datum, then the depth difference between the tops of a given unit and the bases of the next youngest dated unit can be compared with the age differences to yield net subsidence rate estimates (Fig. 2.12). Subsidence rates inferred on this basis from the depths to key units have varied greatly and do not reflect the present-day pattern. In particular, modern rates of subsidence $(2 \pm 1 \mathrm{~mm} / \mathrm{yr}$; from the regional levelling network for the period 1967 to 1986, Allis et al., 1995) associated with TVZ rifting processes can only have been active for only $\sim 50,000$ years, based on elevation differences of the Matahina ignimbrite top surface across the field. The overall rates are comparable to those inferred at Waiotapu by Wilson et al. (2010), and suggest that although the Kawerau area is currently in the area of active modern rifting and faulting, these modern rates have not been sustained through time. 


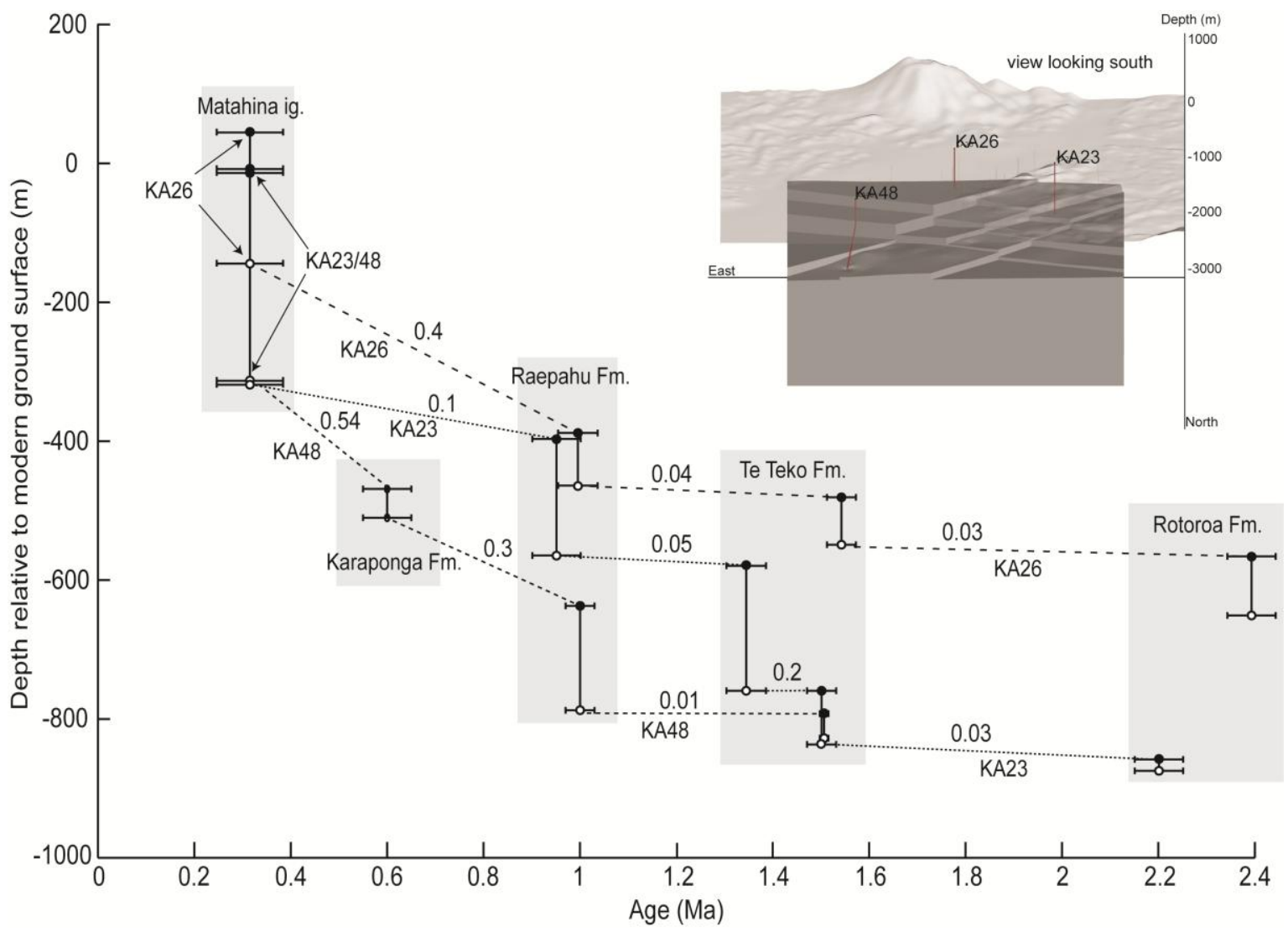

Figure 2.12 Plot of the depths of various stratigraphic units at Kawerau versus their ages from zircon ages (Matahina ignimbrite age from Leonard et al., 2010). All ages have 2 s.d. uncertainties plotted. Open and filled circles represent the base and top of name units, respectively. Lines connect the top of the earlier unit with the base of the later dated unit to define an approximate subsidence rate estimate, plotted alongside the line, in $\mathrm{mm} / \mathrm{yr}$. The grey boxes enclosed dates from the same formation. The locations of the 3 wells plotted are shown on the top right to indicate their relative location in the basement faulted environment.

The change in inferred intrusion geometry from sill (Caxton) to dike (Onepu) indicates a change in principal stress orientations reflecting onset of the development of the modern Whakatane Graben. This change is dated in coastal sedimentary sequences $23 \mathrm{~km}$ to the north of Kawerau as occurring at $\sim 0.37 \mathrm{Ma}$ (G.S. Leonard et al., unpublished data; Leonard et al., 2008), consistent with our age data.

Although inferred to be a long-lived feature, the currently active Kawerau Geothermal Field is a Holocene entity reflecting the rejuvenation of magmatic heat flux associated with Putauaki volcano superimposed on an area of multiply reactivated fault structures and sporadic magmatism and subsidence. 


\subsubsection{Zircon textures as a correlation tool}

As demonstrated here, $\mathrm{U}-\mathrm{Pb}$ dating can play a key role in correlating hydrothermally altered rocks where frequent similarities in the lithologies, and the general destruction by hydrothermal alteration of any distinctive chemical, mineralogical and textural characteristics makes other correlation techniques unviable. In addition to U-Pb dates, zircon textures can be utilised as a broad correlation tool once initial correlation by dating has been achieved. Zircon textures reflect the geological history of the mineral, particularly episodes of magmatic crystallisation or resorption and changes in the uptake of trace elements, as seen in patterns of cathodoluminescence brightness (Corfu et al., 2003; Finch and Hanchar, 2003).

In this study, we have found zircon textures to be sufficiently different between age groupings of tuffs to distinguish them on CL imagery alone, but these differences do not serve to differentiate individual tuffs within these groupings. For example, zircons from the $0.5-0.6$ Ma tuffs of the Karaponga Formation have zircons with moderately complex textures, many of which have dark cores (Fig. 2.13). Zircons in the $\sim 1.45 \mathrm{Ma}$ tuffs of the Te Teko Formation display very complex zonations (Fig. 2.13), while in contrast, zircons from the $\sim 1.0$ Ma Raepahu Formation have very simple zoning, with only thin, moderately dark-CL zones rich in trace elements such as the rare-earth elements, $\mathrm{U}$ and Th (Fig. 2.13).

These textural relationships can in principle be used to confirm correlation of tuffs from any future drillhole sampling at Kawerau on the basis of imagery (coupled with any stratigraphic and petrographic constraints), without the need to undertake further $\mathrm{U}-\mathrm{Pb}$ dating. The textures also serve to confirm correlation with eruptive units elsewhere that show similar age spectra (Fig. 2.13). The deepest of the major tuff units ('Paeroa C') reached at Waiotapu Geothermal Field (45 km southwest of Kawerau) has an age of $\sim 1.45 \mathrm{Ma}$ from zircons (Wilson et al., 2010) with similarly complex textures to those zircons in the Te Teko Formation ignimbrites at Kawerau. Similarly, the age spectra and petrography as well as the zircon textures from sample KA23_2 (KA23, -426 mRL; Raepahu Formation) are closely matched by those from the surficial $\sim 1.0 \mathrm{Ma}$ Kidnappers ignimbrite (as well as its buried and altered equivalent in the Mangakino Geothermal Field: Wilson et al., 2008). 

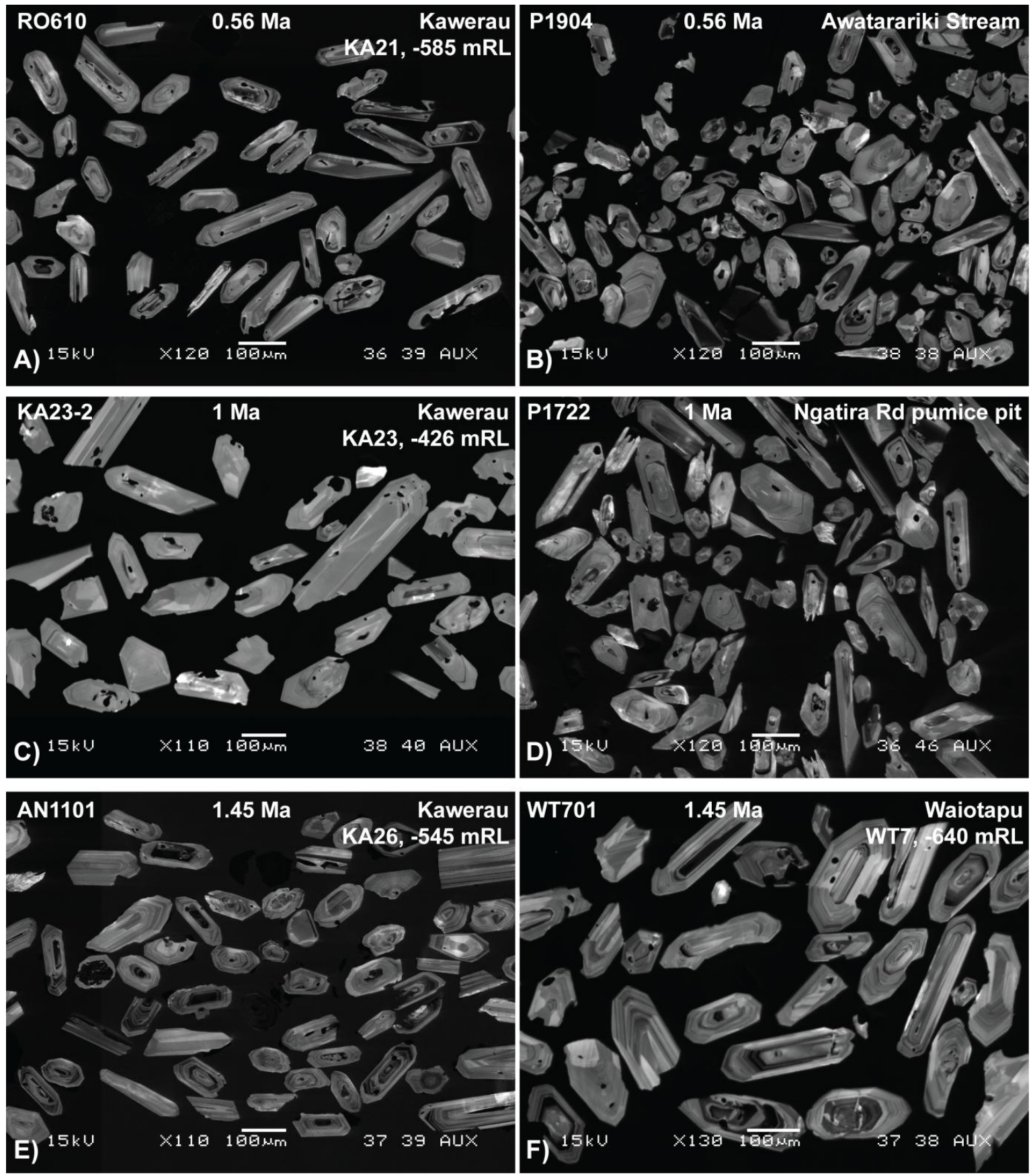

Figure 2.13 0.56 Ma tuffs have zircon with moderately complex textures, with similar textures in a sample from Kawerau (A) and the Awatarariki Stream near Matata (P1904, Fig. 2.1) (B); 1 Ma zircons with simple zoning, with similar textures in a sample from Kawerau $(C)$ and the Ngatira Rd pumice pit (P1722, Fig. 2.1) (D); 1.45 Ma zircons with complex zoning, with similar textures in a sample from Kawerau (E) and Waiotapu (WT701, Fig. 2.1) (F). The images are representative of zircon textures for all units in these age groupings.

\subsubsection{Ignimbrite groupings at Kawerau and comparisons with TVZ}

\section{eruption records}

A noticeable feature of the stratigraphic succession at Kawerau is the grouping of the major thicknesses of ignimbrite or volcanic rocks into packages that have ages overlapping within the uncertainties of pooled ages, with pronounced gaps between the packages. There are no 
deposits thick enough (or present in enough drillholes) to warrant sampling (especially if only cuttings were available) in the time periods between 2.1 and $1.5 \mathrm{Ma}, 1.34 \mathrm{Ma}$ and $1.0 \mathrm{Ma}$, and $\sim 1.0 \mathrm{Ma}$ to $0.6 \mathrm{Ma}$, despite several widespread pyroclastic deposits being present elsewhere in the TVZ from these time intervals (Houghton et al., 1995; Wilson et al., 2010). This situation could reflect (a) that the ignimbrites concerned were not deposited to any extent in the Kawerau area (i.e., thick enough to resist subsequent erosion), and/or (b) topographical controls such as the area being of higher elevation where ignimbrites were only thinly deposited and hence easily eroded, or weathered and consequently altered beyond recognition (see Milicich et al., 2013b). An important implication of our age data is that short depth intervals in the wells can correspond to quite large gaps in time, and vice versa.

Houghton et al. (1995) presented a summary of ${ }^{40} \mathrm{Ar} /{ }^{39} \mathrm{Ar}$ age determinations of major caldera forming events in the TVZ, and inferred that these were not evenly spaced in time, but clustered into three main periods of intense activity (marked in grey in Fig. 2.14). These eruptive periods were separated by significant gaps in time, for which surficial primary eruptive units were lacking, with these gaps also generally associated with changes in source calderas. Studies on distal ash deposits recovered in deep marine cores to the east of the North Island indicated that many other large rhyolitic eruptions had occurred that are not recorded in the surficial on-land ignimbrite succession (Carter et al., 2003, 2004; Pillans et al., 2005; Allan et al., 2008). In addition, the onshore Wanganui Basin incorporates numerous vitric-rich volcaniclastic horizons within Plio-Pleistocene marine sediments which have been dated using magnetostratigraphy, orbitally tuned cyclostratigraphy and isothermal plateau fission track ages (Pillans et al., 2005).

The ignimbrites forming significant thicknesses in the Kawerau Geothermal Field have inferred ages that largely fall into the gaps in the primary onshore ignimbrite record (Fig. 2.14), particularly the units recorded as the Karaponga $(0.5-0.6 \mathrm{Ma})$ and Te Teko $(1.45-1.35 \mathrm{Ma})$ formations. There are, however, corresponding periods of rapid accumulation of ash material occurring in the marine record and in the Wanganui Basin, although in general it is not possible with available data to correlate these with the specific units found at Kawerau. The one notable exception is the Potaka Tephra which is inferred to represent the combined products of the Kidnappers and Rocky Hill eruptions at $\sim 1.0 \mathrm{Ma}$ and mapped elsewhere as the Raepahu Formation (Edbrooke, 2005; Leonard et al., 2010). 


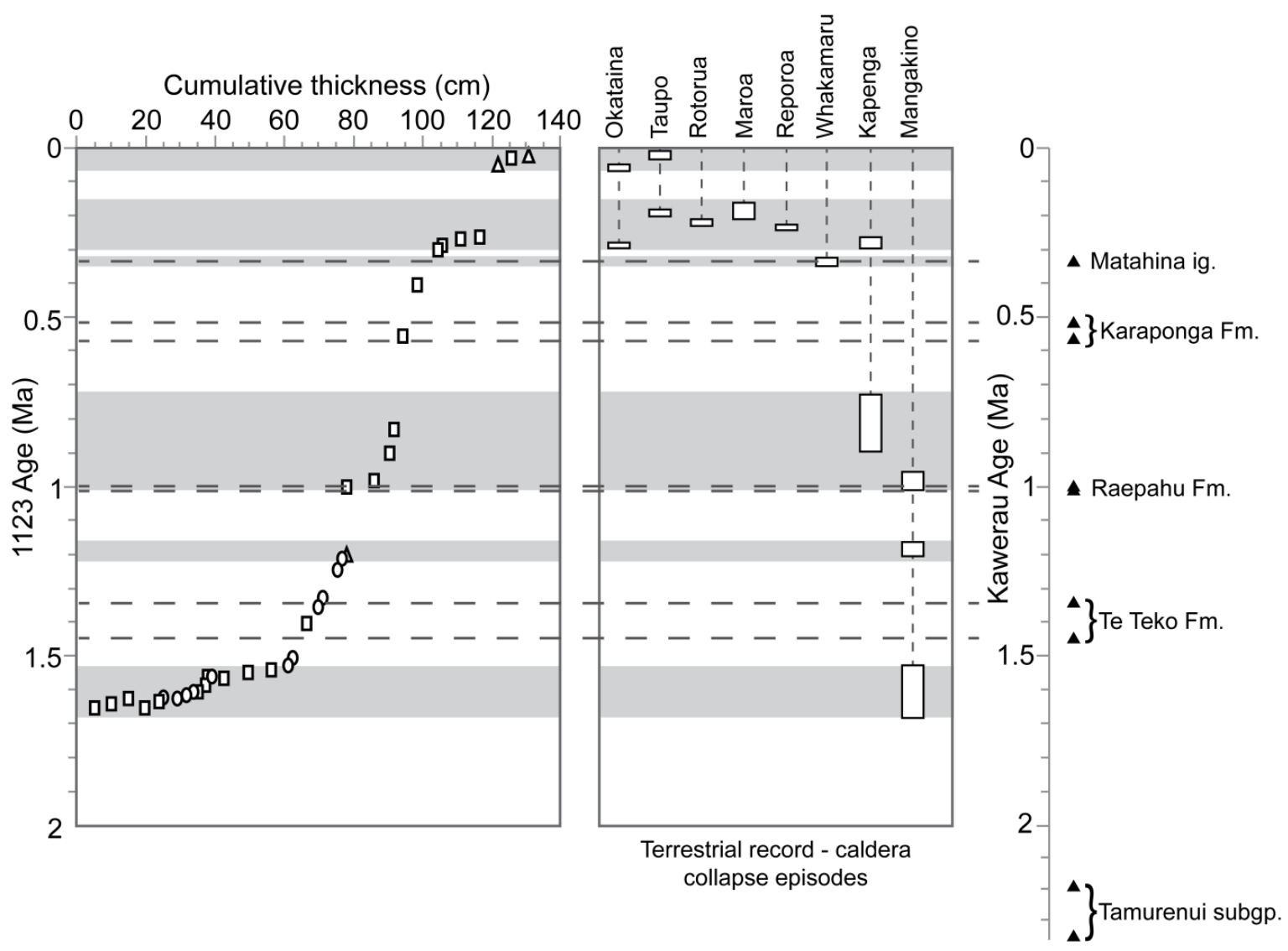

Figure 2.14 Cumulative thickness $(\mathrm{cm})$ of the 37 TVZ-derived tephra eruptive units at Site 1123 plotted against time (Ma) (from Allan et al., 2008). Square symbols indicate orbitally tuned ages, circles indicate interpolated ages for tephras within the disturbed section of the composite age model and triangle symbols denote the age of an on-land correlative. Also shown are the known periods of activity represented by the eight caldera centres within the central TVZ (after Houghton et al., 1995). Dashed lines are for clarity only and do not imply any continuity of the caldera systems. The ages of tuffs in the Kawerau Geothermal Field from the zircon $\mathrm{U}-\mathrm{Pb}$ data are plotted from this paper.

\section{$2.7 \quad$ CONCLUSIONS}

Age determinations from zircons extracted from variably altered buried units at Kawerau Geothermal Field reveal new aspects of the chronology of key marker horizons and the tectono-magmatic evolution of the system.

1. The age spectra obtained from the Kawerau samples, and inferred correlations with three surficial units dated by ${ }^{40} \mathrm{Ar} /{ }^{39} \mathrm{Ar}$ techniques suggests that the weighted mean of the youngest $20-30 \%$ of the grains analysed provides a close approximation to the eruption age of the unit concerned. The weighted average applied to all age data can in some cases be skewed by incorporation of older, unrelated grains, resulting in very high MSWD values, but the age at the peak value of the pdf curve provides a reliable maximum age even where there is a tail of older grains. In situations where the proportions of the $\mathrm{Pb}$ isotopes contributed by common $-\mathrm{Pb}$ are high, the age data appear to be accurate (albeit less precise) with respect to values obtained in pristine 
grains with low common- $\mathrm{Pb}$. A cut-off of $70 \%$ common- $\mathrm{Pb}$ still yields acceptable age estimates for fingerprinting rocks that cannot be dated by any other means.

2. In the Kawerau area, Mesozoic greywacke basement was faulted to form pull-apart structures prior to $1.5 \mathrm{Ma}$. Basinal structures were infilled with greywacke gravels with minor intercalated tuffs and finer sediments, while thin sequences of fine sediments contain tuffs of inferred ages of 2.38 and $2.17 \mathrm{Ma}$. The geometry of the basinal infill sediments and lack of net contemporaneous displacement of greywacke across the field suggest that the faulting was strike-slip dominated, and that by the time of deposition of ignimbrites around $1.45 \mathrm{Ma}$ the area had limited topographic relief.

3. Rates of accumulation of deposits and subsidence across the field have been nonuniform. Thick ignimbrite units recognisable across much of the entire field are clustered in time, with bursts of activity at $1.45-1.35 \mathrm{Ma}, \sim 1.0 \mathrm{Ma}$ and $0.5-0.6 \mathrm{Ma}$. Only two sub-surface ignimbrites can be correlated with surface-mapped units at $\sim 1.0$ Ma (Kidnappers ignimbrite) and $0.56 \mathrm{Ma}$ (Quartz-biotite ignimbrite). Long-term average subsidence rates derived from the depths to the top contacts of dated units are generally $<1 \mathrm{~mm} / \mathrm{yr}$. The $2 \pm 1 \mathrm{~mm}$ modern rates of (pre-exploitation) subsidence cannot have been active for more than $\sim 50,000$ years, based on depths to the top of the $0.322 \mathrm{Ma}$ Matahina ignimbrite

4. Numerous bodies of coherent rhyolite to rhyodacite previously mapped in the field can be shown from geochronology and petrography to represent a combination of dome extrusions and intrusions, rather than domes extruded on many different occasions through the history of the field. The Caxton Formation rhyolites, erupted at $0.36 \mathrm{Ma}$, are represented by crystal richer and crystal-poorer lithologies, each of which is represented by domes and sill intrusions. The $0.138 \mathrm{Ma}$ Onepu Formation rhyodacite is represented by surficial domes and two dike intersections at depth. The corresponding change in orientation of the minimum principal stress axis $\left(\sigma_{3}\right)$ from vertical at $0.36 \mathrm{Ma}$ to horizontal by $0.138 \mathrm{Ma}$ reflects the onset of the modern stress regime associated with TVZ rifting.

5. The present-day Kawerau Geothermal Field is a young (Holocene) feature, spatially superimposed on an area that has seen at least two other periods when magma was present at depth. Magma was present around $0.138 \mathrm{Ma}$ when the Onepu rhyodacite lavas were extruded, and significant amounts of magma were present around $0.36 \mathrm{Ma}$ to feed the Caxton Formation rhyolites. A hydrothermal eruption breccia pre-dating the 
0.32 Ma Matahina ignimbrite probably reflects a hydrothermal manifestation in response to this earlier Caxton magmatic episode, and does not indicate a prolonged continuous history for the field.

\section{$2.8 \quad$ ACKNOWLEDGEMENTS}

We acknowledge funding support for this project from Mighty River Power Ltd and their permission, along with that of Ngati Tuwharetoa Geothermal Assets Ltd, to publish these data. Thanks also go to A8D Trust, Putauaki Trust, Te Tahuna Putakuaki Trust and other local Maori trusts for access to well core and cuttings, and Darren Gravley for the Onepu Dome sample. Additional funding came from a Victoria University PhD scholarship to SDM, and support to CJNW and GB was provided via the Foundation for Research Science and Technology (FRST) PROJ-20199-GEO-GNS “Harnessing New Zealand's Geothermal Resources: Hotter and Deeper", which is now part of the GNS Science CSA (Core Science Area) Geothermal Research Programme. Additional funding for CJNW came from the FRST Programme "Deep Geothermal Resources" through subcontracts from The University of Auckland, by courtesy of Mike O’Sullivan. Simon Barker and Nick Burrows undertook the mineral separations. Peter Holden, Brad Ito and Jorge Vazquez are thanked for their help at various stages in obtaining the ion probe age determinations at the USGS-Stanford University and Australian National University facilities. 
Chapter 2 


\section{CHAPTER 3}

\section{RECONSTRUCTING THE GEOLOGICAL AND STRUCTURAL HISTORY OF AN ACTIVE GEOTHERMAL FIELD: A CASE STUDY FROM NEW ZEALAND}

Sarah D. Milicich, Colin J.N. Wilson, Greg Bignall, Ben Pezaro, Candice Bardsley

Paper published by Journal of Volcanology and Geothermal Research

Manuscript http://dx.doi.org/10.1016/j.jvolgeores.2013.06.004

Statement of authorship: SDM undertook the logging, correlation work. CB assisted SDM

with 3-D modelling and associated discussions. All authors assisted SDM with interpretation of data editing of the manuscript. 


\section{ABSTRACT}

The utilisation of geothermal systems benefits from an understanding of the host-rock geology, locations and controls of permeability pathways, and the nature and timing of magmatic sources providing thermal energy. Kawerau Geothermal Field in the central Taupo Volcanic Zone (TVZ) of New Zealand is currently developed for electricity generation and direct uses of high-temperature steam to $\sim 200 \mathrm{MW}$ electrical equivalent. The Kawerau geothermal system is hosted in a sequence of volcanic lithologies (tuffs, lavas and intrusive bodies) and sediments that overlie faulted Mesozoic metasedimentary (greywacke) basement. Identification of lithologies in the volcanic/sedimentary sequence is challenging due to the levels of hydrothermal alteration and lithological similarities. A combination of detailed petrological investigations, consideration of the emplacement processes and greater certainty of crystallisation or eruption ages through $\mathrm{U}-\mathrm{Pb}$ age determinations on zircons is used to reconstruct the depositional and faulting evolution of the rocks hosting the currently active hydrothermal system. The oldest event inferred is faulting of the greywacke along northwestsoutheast orientated, dominantly strike-slip structures to generate half-grabens that were filled with sediments, incorporating two dated ignimbrites $(2.38 \pm 0.05$ and $2.17 \pm 0.05 \mathrm{Ma})$. A $1.46 \pm 0.01 \mathrm{Ma}$ ignimbrite was deposited relatively evenly across the field, implying that any topographic relief was subdued at that time. Subsequent deposition of ignimbrites occurred in episodes around 1.0, $0.55-0.6$, and $0.32 \mathrm{Ma}$, interspersed with thin sedimentary sequences that accumulated at average rates of $0.06 \mathrm{~mm} \mathrm{yr}^{-1}$. Andesite lavas from a buried composite cone occur as a conformable package between units dated at 1.0 and 0.6 Ma. Bodies of coherent rhyolite occur at multiple stratigraphic levels: two magma types with associated tuffs were emplaced as domes and sills at $0.36 \pm 0.03 \mathrm{Ma}$, and a third type at $0.138 \pm 0.007 \mathrm{Ma}$ as dikes, and domes that are exposed at surface. The andesitic/dacitic Putauaki composite cone southwest of the field first erupted around $8 \mathrm{ka}$, but earlier hydrothermal eruption breccias imply that magma was intruded to shallow depths as early as $\sim 16$ ka.

Age data and associated correlations show that post-1.5 Ma normal faulting has accompanied episodic subsidence of the Kawerau area, with fault movement focussed between northeastsouthwest structures (associated with the geometry of the modern TVZ) and the reactivated northwest-southeast structures associated with most displacement in the area prior to $1.5 \mathrm{Ma}$. Contrasts between emplacement of coherent rhyolite as sills at $0.36 \mathrm{Ma}$ and dikes at $0.138 \mathrm{Ma}$ reflects a shift in orientation of the principal stress axes in response to initiation of the modern TVZ rifting regime. Most volcanic rocks at Kawerau distally sourced from elsewhere in the TVZ but form local marker horizons that delineate topographic relief within the field, and 
additionally constrain past subsidence rates. Current rates of subsidence and thermal output at Kawerau are geologically recent features associated with latest Quaternary rifting processes $(<\sim 50 \mathrm{ka})$ and emplacement of the magmatic system for Putauaki volcano ( $16 \mathrm{ka})$ respectively.

\subsection{INTRODUCTION}

The geological framework of geothermal systems is challenging to quantify and interpret because of the extensive hydrothermal alteration. The high-temperature fluids that make a geothermal system attractive for utilisation and justify industry drilling programmes at low risk also serve to obscure its geological history through hydrothermal alteration. The Taupo Volcanic Zone (TVZ) in New Zealand is one of the world's premier locations for waterdominated geothermal systems with a $>50$ year history of drilling and resource utilisation (Grant and Southon, 1986; Mongillo, 1986; Hotson, 1994; Spinks et al., 2010). Despite a long history of studying geothermal system geology in the TVZ, there is much still to learn about the geology, absolute ages and structure of geothermal systems in the overall volcano-tectonic history of this area, primarily because of a paucity of direct age data for rock units. In New Zealand and globally, the subsurface stratigraphy in geothermal systems is most often reconstructed from petrographic correlations with independently dated surficial units (e.g., Grindley, 1965; Browne, 1978a, Stimac et al., 2008; Rosenberg et al., 2009). Surprisingly, there have been only limited numbers of dating studies of active hydrothermal systems, with those studies designed to resolve the source of heat that drives the system, e.g., at The Geysers, California (Dalrymple et al., 1999; Schmitt et al., 2003a, b) and Ngatamariki, New Zealand (Arehart et al., 2002), but more recently the value of dating has become apparent as a correlation tool (Wilson et al., 2008, 2010). Milicich et al. (2013a) used U-Pb dating of zircons to date marker units in the Kawerau geothermal system. In this paper we use these data along with summary lithological observations to present a more reliable 3-D geological architecture, and structural and thermal history of the Kawerau system as a demonstration of the value of combined geological and dating studies in geothermal systems.

Kawerau is the most northeastern of the active high-temperature geothermal systems in the TVZ (Fig. 3.1; Bibby et al., 1995; Rowland and Sibson, 2004; Kissling and Weir, 2005; Rowland and Simmons, 2012). In regard to its volcano-magmatic setting, Kawerau is situated at the transition between rhyolite-dominated caldera-related activity that characterises the central TVZ and the northern TVZ arc of andesite-dacite composite cones (Wilson et al., 1995a; Nairn, 2002). The Kawerau geothermal system occurs in the southern part of the 
Whakatane Graben (Fig. 3.1), in an area where normal faulting of the TVZ rift interacts with the dominantly strike-slip faulting of the North Island Shear Belt (Nairn and Beanland, 1989; Mouslopoulou et al., 2007; Begg and Mouslopoulou, 2010; Villamor et al., 2011). In this paper, we use the term 'Kawerau geothermal system' to refer to the natural entity, and 'Kawerau Geothermal Field' to refer to the geothermal resource and the infrastructure and land boundaries associated with the geothermal power station.

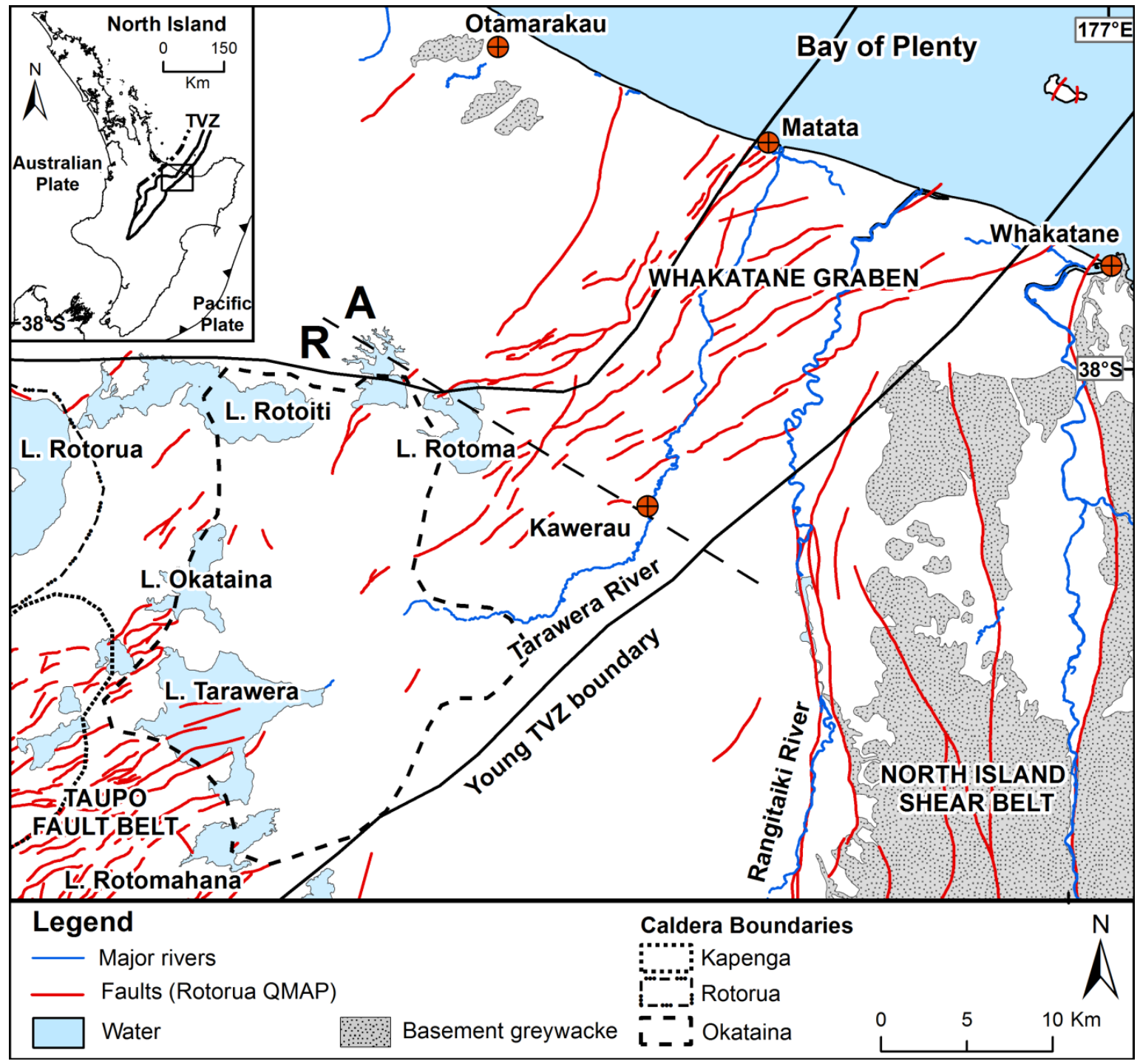

Figure 3.1 Locality and structural map of the local Kawerau area. The young (350 ka to present) boundary to the TVZ is shown, with its subdivisions into andesite-dominated (A) northern segment and the rhyolite dominated (R) central segment. Caldera boundaries from Wilson et al. (2009); faults and greywacke outcrop areas from Leonard et al. (2010).

\subsection{GEOLOGICAL FRAMEWORK FOR THE KAWERAU SYSTEM}

Numerous wells used for geothermal production, injection and monitoring have been drilled at Kawerau (Fig. 3.2) and cores and cuttings from most of these have been re-examined 
(Milicich, 2013a,b [Electronic Appendices 1,2]) and combined with the U-Pb age controls (Milicich et al., 2013a) to provide a new, consistent stratigraphic framework.

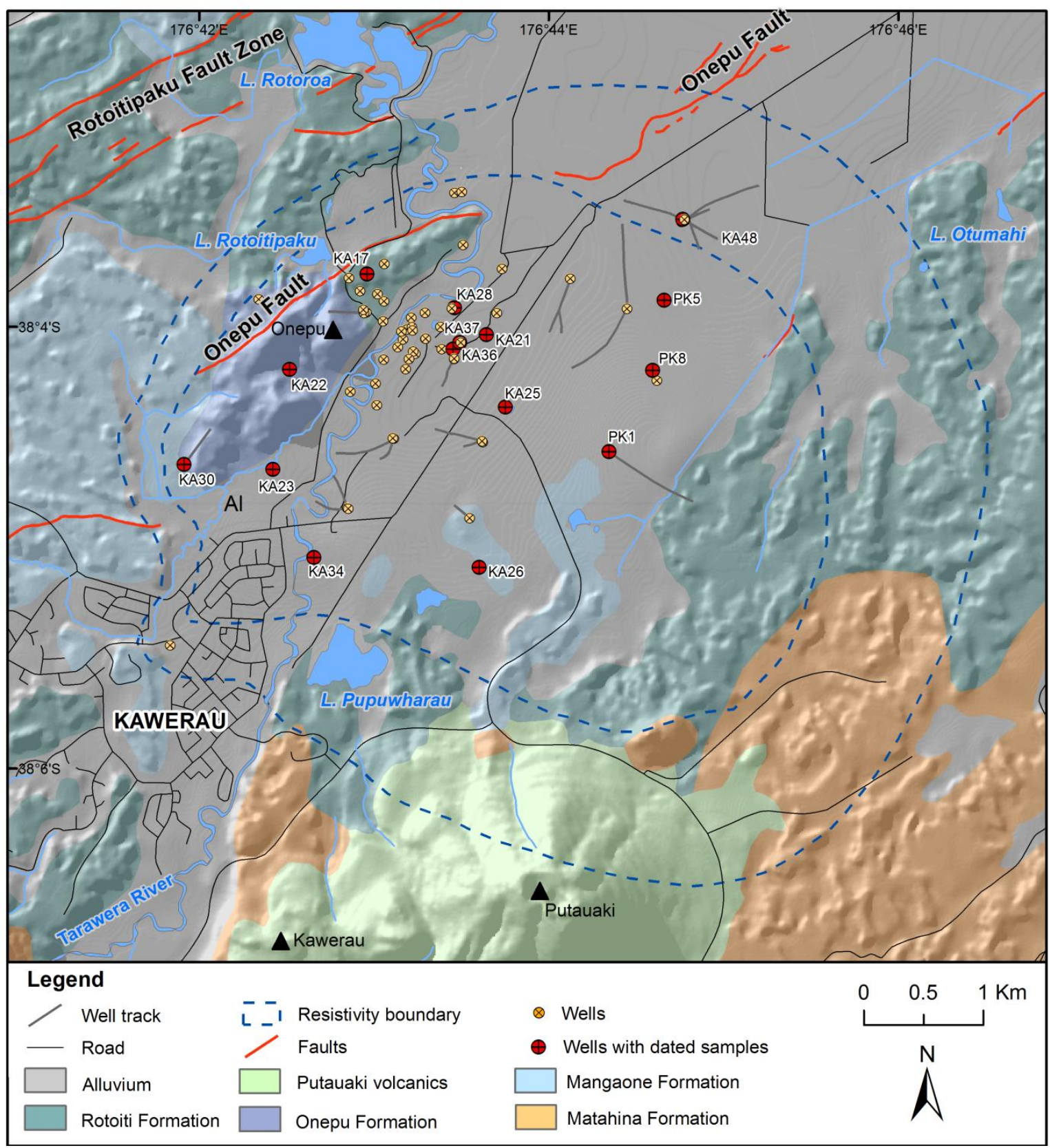

Figure 3.2 Map of Kawerau Geothermal Field showing drillholes, active faults (GNS Science, 2013), and approximate resistivity boundary zone defined at about $500 \mathrm{~m}$ depth (after Allis, 1997). Geology map units are after Leonard et al. (2010), with alluvium representing the alluvial deposits from breakout floods down the Tarawera River (Hodgson and Nairn, 2005).

Detailed stratigraphic logs and petrographic thin section descriptions are presented in Milicich (2013a,b) [Electronic Appendices 1, 2], and a full suite of graphic stratigraphic logs is in Appendix A. The renaming of units has followed the approach used in Edbrooke (2005) and Leonard et al. (2010) where volcanic genetic terms are kept distinct from formal stratigraphic units. As an example, ignimbrites may have fall deposits and post-eruptive reworked materials associated with them that are of discrete genetic origins. Here, we group chronologically 
linked materials, regardless of origin, as formations for mapping purposes. This stratigraphic approach is more useful and flexible than the volcanic genetic terminology used previously at Kawerau (reviewed by Bignall and Harvey, 2005) and widely elsewhere in New Zealand geothermal field descriptions. The revised stratigraphy results from an integrated approach of logging drill cuttings, core hand specimen, petrographic thin sections and age data, and the realisation that any of these techniques on their own would have been insufficient to allow accurate delineation and correlation of the stratigraphy. The revised stratigraphic framework is summarised in Table 3.1, and discussed below, with a graphical comparison to the previously published stratigraphy in Fig. 3.3. Table 3.2 shows a comparison from the previous stratigraphy summarised in Bignall and Harvey (2005) to that used in this paper.

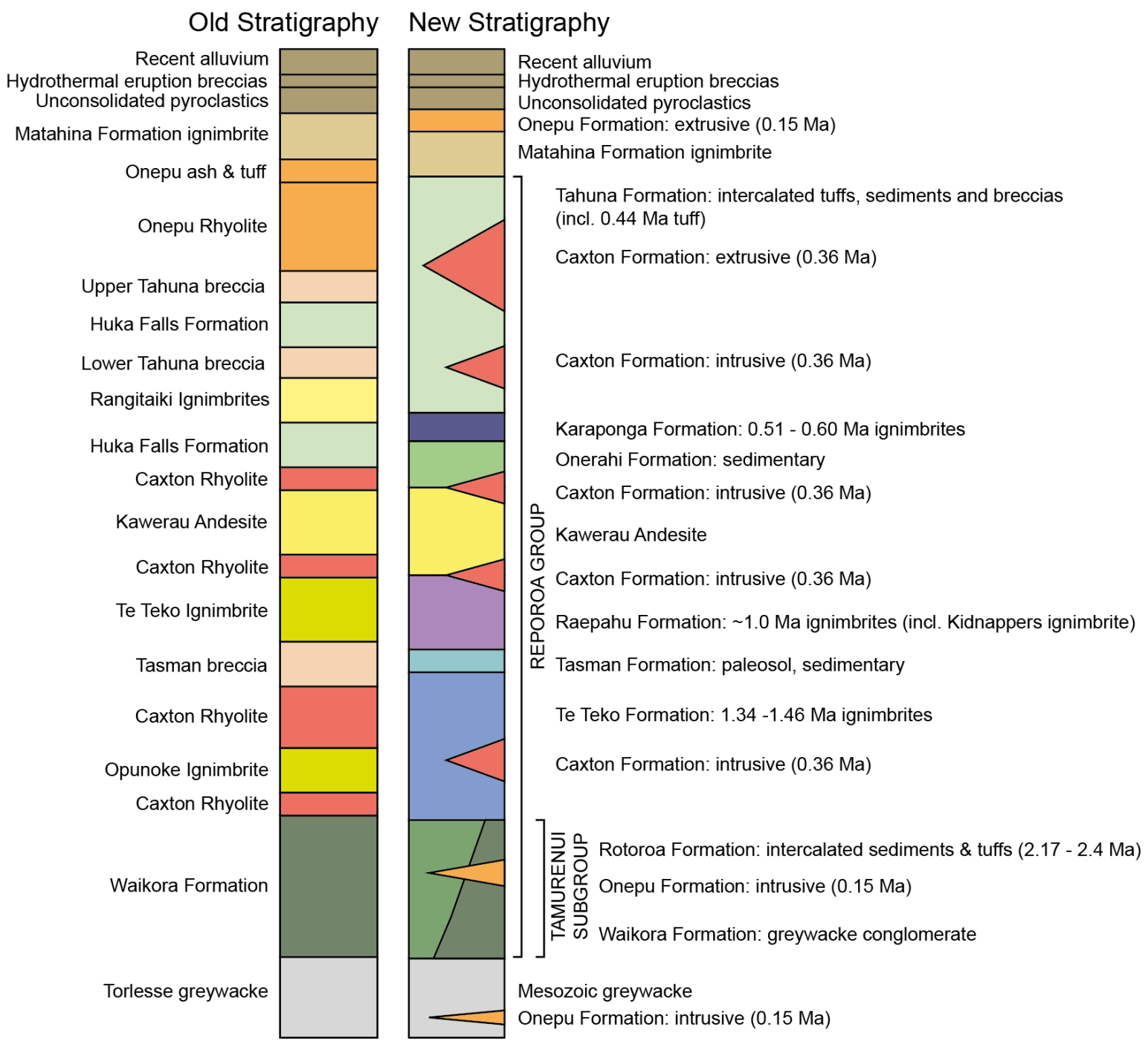

Figure 3.3 Summary comparative stratigraphic logs of the main geology units in Kawerau geothermal system (Table 3.1). The old stratigraphy is summarised in Bignall and Harvey (2005). 
Table 3.1 Summary of the main stratigraphic units and lithologies in the Kawerau geothermal system (ages from Milicich et al., 2013a).

\begin{tabular}{|c|c|c|c|c|}
\hline Formation & Lithology & $\begin{array}{l}\text { Thickness } \\
\text { (m) }\end{array}$ & $\begin{array}{l}\text { Age } \\
(\mathrm{Ma})\end{array}$ & $\begin{array}{l}\text { Type Section } \\
(\mathrm{mRL})\end{array}$ \\
\hline Recent Alluvium & $\begin{array}{l}\text { Peat deposits; sands and gravels; unconsolidated pyroclastic } \\
\text { deposits (incl. Whakamana Breccia, Rotoiti Breccia) }\end{array}$ & $10-50$ & & \\
\hline $\begin{array}{l}\text { Hydrothermal Eruption } \\
\text { Breccias }\end{array}$ & Hydrothermal eruption deposits, from $\sim 16,000$ and $\sim 9,000 \mathrm{yr} \mathrm{BP}$ & $1-10$ & & \\
\hline $\begin{array}{l}\text { Unconsolidated } \\
\text { pyroclastics }\end{array}$ & Unwelded pumiceous pyroclastic flow and airfall tuffs & $0-80$ & & $\begin{array}{l}\text { KA27 } \\
(25 \text { to }-55)\end{array}$ \\
\hline Onepu Formation $\#$ & $\begin{array}{l}\text { Twin surficial domes of rhyodacite (pl, qz, px, hb, bt) and intrusive } \\
\text { (porphyritic crystal-rich; corroded } \mathrm{qz}, \mathrm{pl}, \text { mafics) }\end{array}$ & $2-200$ & 0.15 & $\begin{array}{l}\text { KA30 } \\
(-739 \text { to }-849)\end{array}$ \\
\hline Matahina Formation & Partly welded grey-brown ignimbrite \& vitric tuff (pl, qz, px) & $10-410$ & $0.32 *$ & $\begin{array}{l}\text { PK3 } \\
(-11 \text { to }-244)\end{array}$ \\
\hline Tahuna Formation ${ }^{\#}$ & $\begin{array}{l}\text { Crystal-rich, fine sandstone, siltstone, muddy lithic-breccia and } \\
\text { unwelded pumice-rhyolite lapilli tuff }\end{array}$ & $0-360$ & 0.44 & $\begin{array}{l}\text { KA21 } \\
(-477 \text { to }-570)\end{array}$ \\
\hline Caxton Formation ${ }^{\#}$ & $\begin{array}{l}\text { Buried domes of spherulitic and banded rhyolite (corroded and } \\
\text { fractured qtz and } \mathrm{pl} \text { ) and intrusive (corroded and fractured qtz and } \\
\mathrm{pl}, \pm \mathrm{bt} \pm \mathrm{amp} \text { ) }\end{array}$ & $0-450$ & 0.36 & $\begin{array}{l}\text { KA17 } \\
(-167 \text { to }-307)\end{array}$ \\
\hline Karaponga Formation ${ }^{\#}$ & Partly welded crystal-lithic tuffs (pl, qz \pm bt) & $0-180$ & $0.51-0.60$ & $\begin{array}{l}\text { KA21 } \\
(-570 \text { to }-624)\end{array}$ \\
\hline Onerahi Formation $\#$ & Tuffaceous to muddy breccias and coarse tuffaceous sandstone & $0-85$ & & $\begin{array}{l}\text { KA17 } \\
(-563 \text { to }-630)\end{array}$ \\
\hline Kawerau Andesite & Augite-plagioclase andesite flows, breccias and tuff (in south) & $0-300$ & & $\begin{array}{l}\text { KA48 } \\
(-507 \text { to }-644)\end{array}$ \\
\hline Raepahu Formation & $\begin{array}{l}\text { Partly welded crystal-vitric tuffs (qz,pl,bt, lithic-poor and qz,pl,bt, } \\
\text { ferromagnesians, lithic-rich) }\end{array}$ & $0-165$ & 1 & $\begin{array}{l}\text { KA23 } \\
(-400 \text { to }-564)\end{array}$ \\
\hline Tasman Formation ${ }^{\#}$ & $\begin{array}{l}\text { Muddy breccia, sandstone and siltstone, but widely represented by } \\
\text { reddish brown siltstone }\end{array}$ & $0-25$ & & $\begin{array}{l}\text { KA48 } \\
(-781 \text { to }-786)\end{array}$ \\
\hline Te Teko Formation ${ }^{\#}$ & Partly welded grey crystal-vitric ignimbrite (corroded qz, pl, bt) & $0-255$ & $1.34-1.46$ & $\begin{array}{l}\text { KA23 } \\
(-583 \text { to }-839)\end{array}$ \\
\hline Rotoroa Formation ${ }^{\#}$ & $\begin{array}{l}\text { Tuffaceous sandstone, poorly sorted crystal and vitric-rich, water- } \\
\text { laid tuff, siltstone }\end{array}$ & $0-200$ & $2.17-2.4$ & $\begin{array}{l}\text { KA25 } \\
(-706 \text { to }-898)\end{array}$ \\
\hline Waikora Formation & $\begin{array}{l}\text { Greywacke pebble conglomerate and minor intercalated tuff and } \\
\text { siltstone }\end{array}$ & $0-450$ & & $\begin{array}{l}\text { KA48 } \\
(-820 \text { to }-1285)\end{array}$ \\
\hline Greywacke basement & Weathered, sheared greywacke and argillite & - & & \\
\hline
\end{tabular}

Abbreviations used are $\mathrm{pl}=$ plagioclase; $\mathrm{qz}=$ quartz; $\mathrm{px}=$ pyroxene; $\mathrm{hbl}=$ hornblende; $\mathrm{bt}=$ biotite; amp $=$ amphibole. $*$ Leonard et al. (2010). \# new stratigraphic names defined by this study. The Rotoroa and Waikora Formations are part of the Tamurenui subgroup\#. 


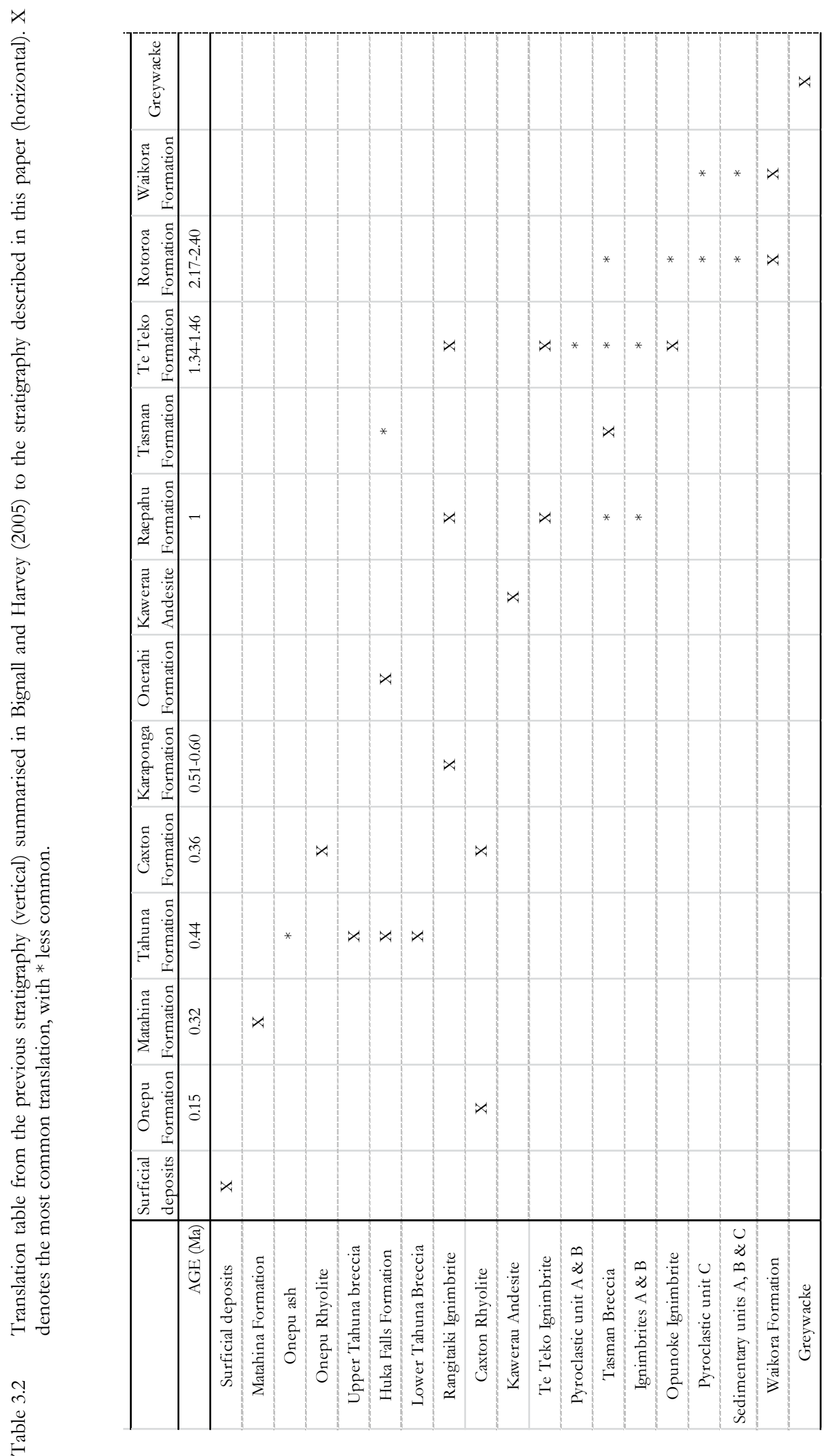




\subsubsection{Latest Quaternary units}

Deposits in this grouping represent volcanic, hydrothermal and sedimentary processes over the past $\sim 61,000$ years. No mappable units are recognised that were deposited or erupted between $\sim 61 \mathrm{ka}$ and the $0.138 \mathrm{Ma}$ Onepu domes. The latest Quaternary units fall into four categories.

Recent Alluvium: These are represented by sands and gravels deposited in the Tarawera River flood plain over the last $\sim 60,000$ years, both as background sedimentary flux and as catastrophic inundations of volcaniclastic material in break-out floods following eruptions upstream at the Okataina volcano (Hodgson and Nairn, 2004, 2005). The youngest of these was deposited in 1904 following the 1886 eruption of Tarawera (Allis et al., 1995; White et al., 1997) while flood deposits associated with the aftermath of the 1315 Kaharoa eruption also inundated the field area (Hodgson and Nairn, 2004, 2005). Partly due to this rapid sediment influx, there are no surface fault traces mapped within the western (drilled) part of the Kawerau Field (Allis et al., 1995). Surface faulting at the time of the 1987 Edgecumbe earthquake occurred along the Rotoitipaku fault zone and Onepu fault $(0.05-0.3 \mathrm{~m}$ slip), $\sim 1$ $\mathrm{km}$ from the northwest margin of the field (Fig. 3.2; Berryman et al., 1998).

Mt Edgecumbe (Putauaki) volcanics: The $\sim 800 \mathrm{~m}$-high composite cone of Putauaki volcano dominates the topographic relief of the Kawerau area. Its eruptive activity is bracketed by ${ }^{14} \mathrm{C}$ ages of 9,500 cal. years B.P. on an underlying regional rhyolite fall deposit (Rotoma tephra: Lowe et al., 2013) and 3,400 cal. years B.P. on late-stage block-avalanche deposits (Carroll et al., 1997). Two main eruptive episodes have been recognised: earlier dacitic lavas forming the base and western part of Putauaki, and the main cone growth of high- $\mathrm{SiO}_{2}$ andesite lavas (Nairn, 1995). A small satellite cryptodome on the northeastern flank of Putauaki has intruded into and altered the overlying Matahina ignimbrite (Bailey and Carr, 1994). No Putauaki eruptive materials are recognised in the Kawerau drillholes, and the volcanic activity did not produce any widely dispersed pyroclastic fall material.

Hydrothermal eruption breccias: Two young hydrothermal eruption breccia deposits were mapped by Nairn and Wiradiradja (1980) in the southeast part of the field, interbedded with ${ }^{14} \mathrm{C}$ dated regionally distributed pyroclastic sequences. The breccias contain clasts of hydrothermally altered Matahina ignimbrite and Onepu rhyolite, the presence of which implies an excavation depth of at least $-116 \mathrm{mRL}(\mathrm{RL}=$ reduced level, i.e., with respect to sea level). The lower eruption breccia ( 16 ka; Fig. 3.2) is bracketed by the Rerewhakaitu (17,400 cal. years B.P) and Rotorua tephras (15,700 cal. years B.P) while the upper eruption breccia ( 9 
ka) rests on the Rotoma Tephra (9,500 cal. years B.P) and is covered by the Mamaku Tephra (8,000 cal. years B.P) (Nairn and Wiradiradja, 1980; ages from Lowe et al., 2013). Bromley (2002) suggested that an interpreted localised high-resistivity layer beneath the inferred location of the eruption craters could be a 'relatively young and unaltered intrusive dyke or sill' which provided the thermal impetus for the hydrothermal eruptions. At least 7 eruption centres have been identified (Christenson, 1987). Shallow depressions, some with stagnant pools and including the hydrothermal feature once known as Boiling Lake and Lake Pupuwharau are also likely due to hydrothermal eruptions (Christenson, 1987).

Unconsolidated pyroclastic deposits: The Kawerau area has received numerous fall deposits and at least three ignimbrites, non-welded in the area considered here, from recent activity at the nearby Okataina volcano (Jurado-Chichay and Walker, 2000; Nairn, 2002). Two of the ignimbrites are thick enough to form mappable deposits on the margins of the field: the 61 ka Rotoiti Formation and 34 ka Mangaone Formation ignimbrites (Nairn, 2002; Leonard et al., 2010). In drillholes within the field, Grindley (1986) correlated unwelded breccia and pumiceous tuff (which thickens from $\sim 20 \mathrm{~m}$ in the KA34 area, to $100 \mathrm{~m}$ in KA32) with the Rotoiti Formation ignimbrite.

\subsubsection{Onepu Formation extrusive domes and intrusive bodies}

The Onepu Formation, consisting of surficial extrusive domes and correlative dike intrusion(s), represents the next youngest magma beneath the field prior to Putauaki. The domes have been ${ }^{40} \mathrm{Ar} /{ }^{39} \mathrm{Ar}$ dated at $0.138 \pm 0.007 \mathrm{Ma}$ (by M.A. Lanphere and B.F. Houghton), and three samples from the dome and dikes returned an estimated eruption age from $\mathrm{U}-\mathrm{Pb}$ dating of zircons that is identical within uncertainty at $0.15 \pm 0.01 \mathrm{Ma}$ (Milicich et al., 2013a). The lava is petrographically distinct from other rhyolite bodies at Kawerau, being crystal-rich, with phenocrysts of plagioclase and quartz (together $\sim 30 \%$ of the rock), amphibole $(\sim 5-10 \%)$, pyroxene and magnetite, set in a crystalline groundmass including laths of plagioclase, amphibole and quartz (Fig. 3.4A). Quartz are embayed, fractured and subrounded (0.5 - $5 \mathrm{~mm}$ diam.) and plagioclase frequently form glomerocrysts. Xenolithic agglomerates of plagioclase, amphibole and pyroxene are a minor component. Beneath the field, this formation is represented by quartz porphyry dikes (Fig. 3.5), inferred to be part of a feeder system, cutting the Rotoroa Formation in KA30 (-739 to $-849 \mathrm{mRL})$ and greywacke basement in KA28 (-1320 to $-1390 \mathrm{mRL})$; KA42 (-978 to $-988 \mathrm{mRL})$ and PK8 (-2638 to -2639 $\mathrm{mRL})$. 


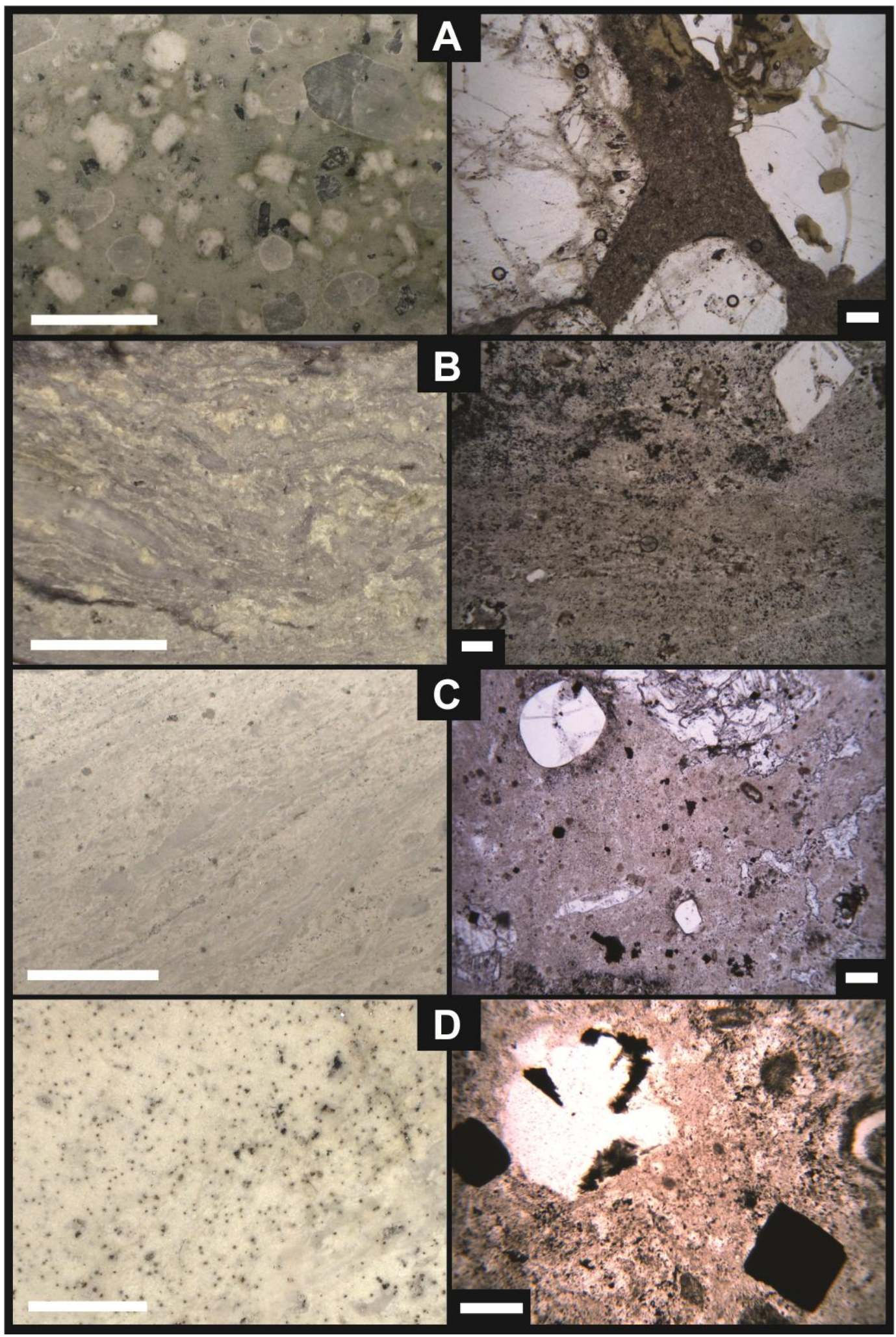

Figure 3.4 Examples of hydrothermally altered intrusive and extrusive coherent rhyolite of the Onepu (0.138 $\mathrm{Ma})$ and Caxton $(0.36 \mathrm{Ma})$ formations at Kawerau. Images on the left are hand specimen, with the scale bar indicating $1 \mathrm{~cm}$ in all images. Images on the rights are photomicrographs of thin sections from the same specimen, with the scale bar indicating $200 \mu \mathrm{m}$ in all images. A) KA30 -739 mRL. Onepu Formation intrusive. Distinctive texture with large fractured and embayed quartz, plagioclase and amphibole phenocrysts. B) KA21 -418 mRL. Caxton Formation extrusive. Flow banded with minor quartz and plagioclase phenocrysts. C) KA36 -655 mRL. Caxton Formation intrusive. Faint flow banding partially obscured by hydrothermal alteration with minor quartz and plagioclase phenocrysts. D) KA36 -944 mRL. Caxton Formation intrusive. High degrees of hydrothermal alteration obscure any primary textures. Minor phenocrysts of quartz and plagioclase are present. 


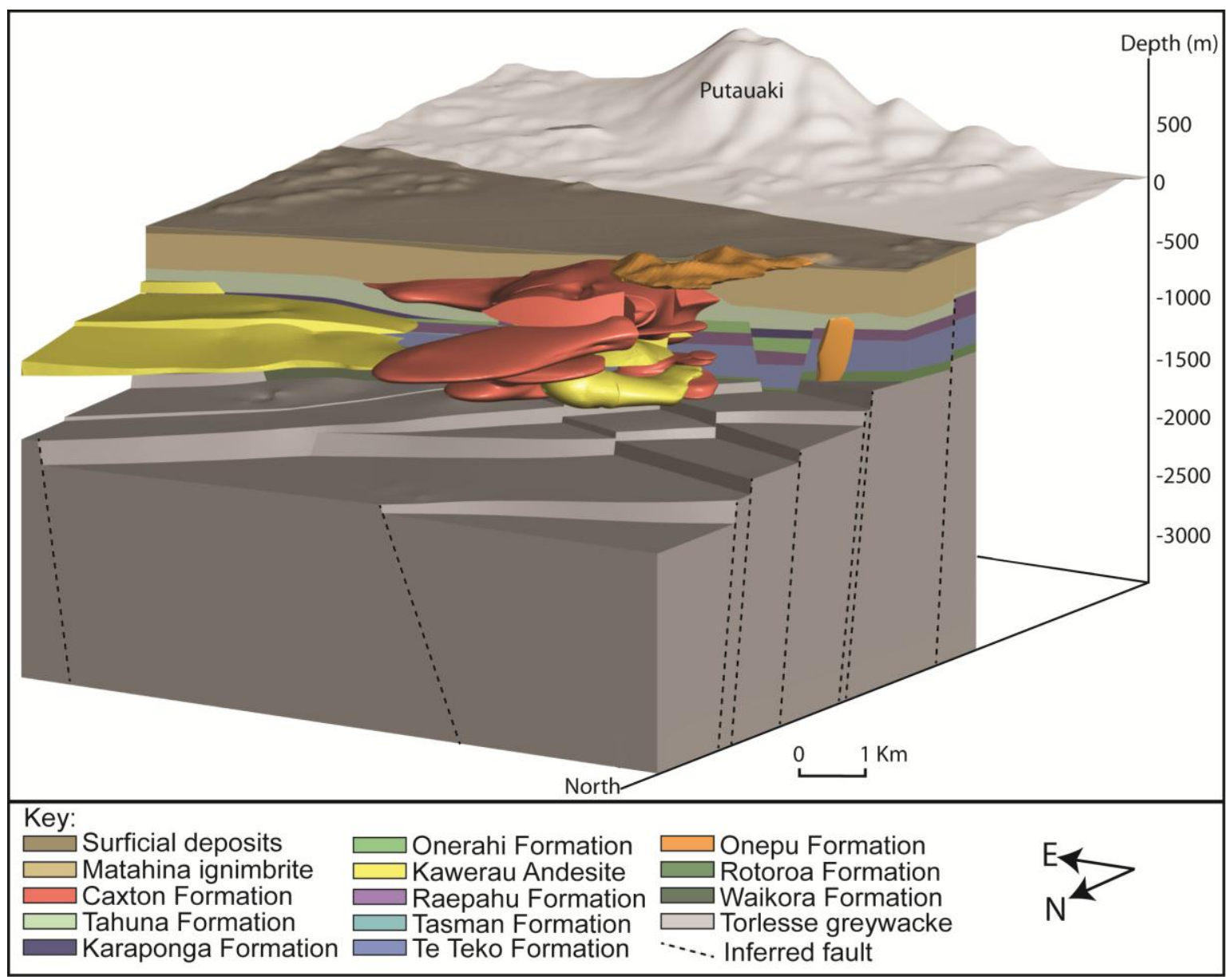

Figure 3.5 3-D geological model of the Kawerau geothermal system, highlighting the extent of the Kawerau Andesite, Caxton Formation and Onepu Formation.

\subsubsection{Matahina Formation}

The regionally distributed Matahina Formation consists of a voluminous $\sim 2000 \mathrm{~km}^{2}$ partially welded ignimbrite and its associated fall deposit ( $<10 \mathrm{~m}$ thickness), which erupted from Okataina volcano at $0.322 \pm 0.007 \mathrm{Ma}$ (Bailey and Carr, 1994; Manning, 1996; Leonard et al., 2010; Deering et al., 2011). The ignimbrite crops out to the north, south and east of the Kawerau area, and is encountered at depths of $10-330 \mathrm{~m}$ beneath the geothermal field. The ignimbrite is partially welded and jointed and hosts a shallow aquifer that facilitates nearsurface flow of cold groundwaters across the field. The sub-surface extent of the Matahina Formation ignimbrite has been revised as part of this study, and it is now recognised in several wells (e.g., KA3, KA16 - 19 and KAM1 - 4) where it had previously been described as 'Whakamana Breccia' or 'Rotoiti Breccia' (Browne, 1978a). The thickness of the Matahina Formation ignimbrite within the field is variable $(10-410 \mathrm{~m})$, and is inferred to be primarily controlled by topographic relief developed on the Caxton Formation rhyolite dome complex, with the ignimbrite thickening towards the east of the field where the older rhyolite domes are absent. 


\subsubsection{Caxton Formation extrusive domes and intrusive bodies}

Brecciated to massive, flow banded rhyolite lavas (previously called Onepu Rhyolite by Grindley, 1986) up to $450 \mathrm{~m}$ thick occur in northern (e.g. KA32) and southwest (KA23, KA30) areas of the field, locally interbedded with breccias (probable dome-margin), tuff and fluviatile pumiceous sediments. Beneath these flow banded rhyolite lavas, coherent rhyolite (the Caxton Rhyolite of Grindley, 1986 and Allis et al., 1995) intersected in drillholes had been inferred to have been extruded from multiple vents, forming a dome complex interbedded with Kawerau Andesite and several ignimbrite units. U-Pb zircon age data indicate that the two rhyolite units have, within uncertainty, the same eruption age $(\sim 0.36 \mathrm{Ma}$; Milicich et al., 2013a), and we grouped them all as the Caxton Formation, representing a series of sills feeding a now-buried dome complex (Fig. 3.5). Within both the intrusive and extrusive members of the Caxton rhyolites are crystal-poorer and crystal-richer variants. The crystalpoorer member has small $(<2 \mathrm{~mm}$ long) crystals of quartz and plagioclase \pm biotite \pm amphibole (Fig. 3.4B, C, D). The crystal-rich variety has embayed quartz (0.5 - $6 \mathrm{~mm}$ diam.) and plagioclase $(<2 \mathrm{~mm}$ long $) \pm$ biotite \pm amphibole. The crystal-rich unit is less extensive than the crystal-poor rhyolite and is present in KA16, KA17, KA19, KA22 and KA23 as extrusive lava and breccia. U-Pb eruption age estimates for the crystal-richer $(0.36 \pm 0.02 \mathrm{Ma}$, Milicich et al., 2013a) and crystal-poorer (0.36 \pm 0.03 Ma, Milicich et al., 2013a) members are almost identical, as are ages for inferred intrusive versus extrusive units. Possible surficial lavas which are age correlatives crop out northwest of Kawerau along the northeastern side of Okataina volcano in the Lake Rotoma area (Nairn, 2002; Cole et al., 2010; Leonard et al., 2010), and abundant fresh rhyolite lava lithic fragments occur in the proximal Matahina Formation ignimbrite (Cole et al., 2010). These observations suggest that there may have been extensive (tens to hundreds of square kilometres) areas of effusive rhyolite volcanism in this general time period.

\subsubsection{Tahuna Formation sedimentary and volcaniclastic units}

Sedimentary units and intercalated tuffs contemporaneous with the Caxton Formation are grouped as the Tahuna Formation. The main lithologies in the Tahuna Formation are: (1) crystal-rich, fine sandstone with variable lithic content; (2) pale brownish-grey, fine sandstone/siltstone; (3) lithic breccia with a muddy matrix (Fig. 3.6B); and (4) pumiceous and vitric tuffs with variable lithic content and crystals of quartz and plagioclase. Tahuna Formation sediments are sometimes carbonaceous, with minor proportions of pyroclastic and diatomaceous material. Zircons from within a Tahuna Formation tuff have yielded an 
eruption age estimate of $0.44 \pm 0.02 \mathrm{Ma}$ (Milicich et al., 2013a). The Tahuna Formation pyroclastic deposits are spatially associated with the Caxton rhyolites and are likely to be locally sourced, based on their thicknesses, and derived from the same magmatic source that subsequently gave rise to the Caxton extrusive and intrusive rhyolites.

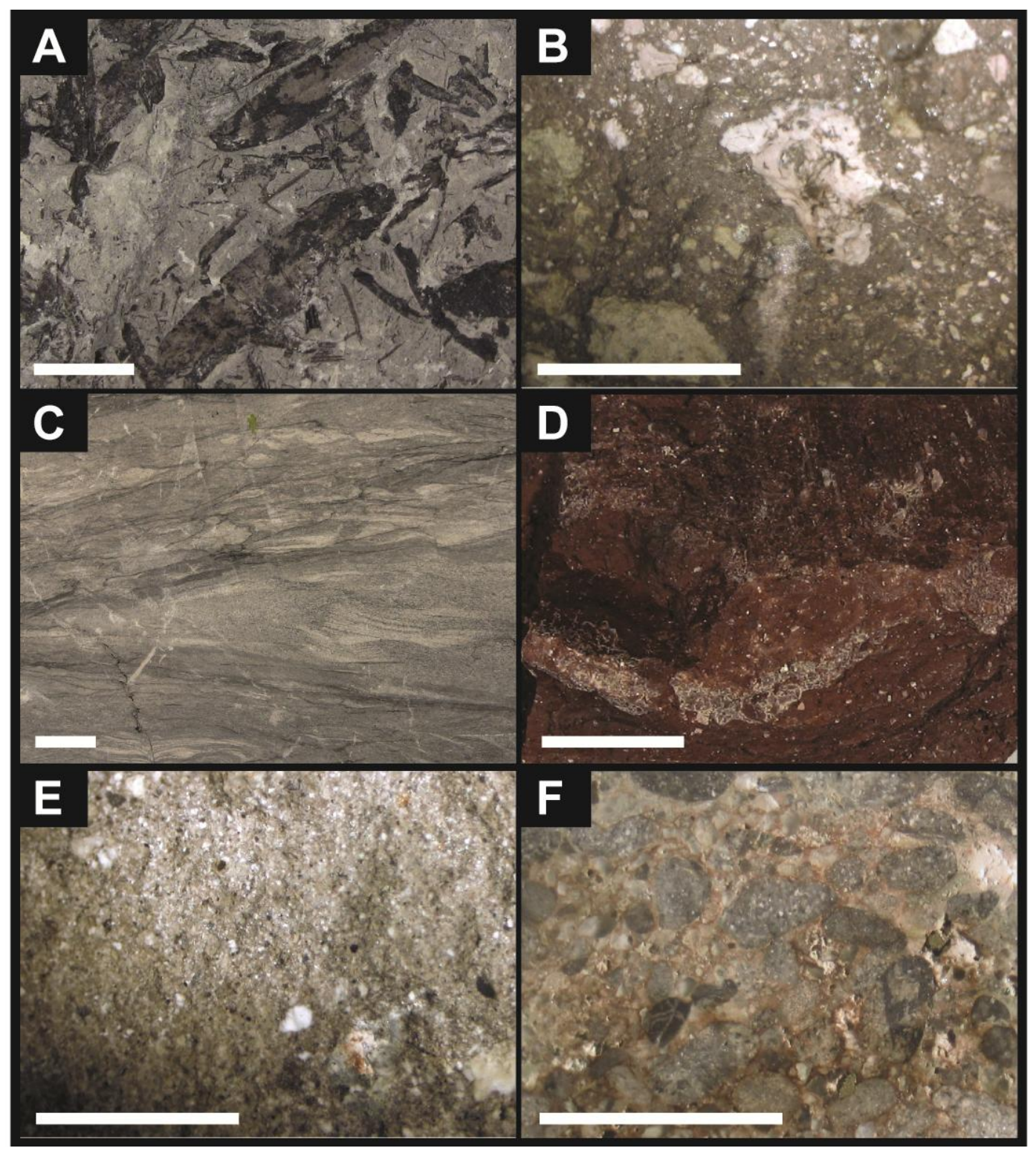

Figure 3.6 Examples of hydrothermally altered sedimentary rocks at Kawerau. The scale bar indicates $1 \mathrm{~cm}$ in all images. A) KA25 -965 mRL. Waikora Formation. Carbonaceous siltstone with leaf imprints. B) KA21 -631 mRL. Onerahi Formation. Breccia with clasts of ignimbrite, rhyolite lava, sandstone and siltstone in a muddy vitric matrix. C) PK1 $-810 \mathrm{mRL}$. Waikora Formation. Bedded grey siltstone. D) KA25 -710 mRL. Rotoroa Formation. Red sediments inferred to represent development of a palaeosol. E) KA21 -520 mRL. Tahuna Formation. Medium-grained sandstone. F) KA27 -953 mRL. Waikora Formation. Matrix supported greywacke conglomerate.

The Tahuna Formation is inferred to be mostly terrestrial, with intercalated carbonaceous siltstones and crystal-rich sandstones dominating the volcano-sedimentary sequence. These deposits also include some shallow marine sediments, with shells (Nucula sp.) recorded at 400 $\mathrm{m}$ depth in KA22 (Browne, 1978a; Christenson, 1987). The type section for the Tahuna 
Formation is in KA21 where the formation is $92 \mathrm{~m}$ thick, and the thickest occurrence is in KA22 (385 m) where pumiceous tuffs, coarse to medium sandstone and muddy sedimentary tuffaceous breccias dominate.

Lithological variations in the sedimentary horizons are gradational, and correlation between wells is hampered by lateral variability in thickness (10 to $280 \mathrm{~m}$ ). The fine-grained sediments form a discontinuous, relatively impermeable aquiclude across the field (at $\sim 400 \mathrm{~m}$ depth) between the overlying Caxton Formation aquifer and the underlying fractured Kawerau Andesite and ignimbrite reservoirs. The succession in KA25 includes a breccia of possible hydrothermal eruptive origin (Browne, 1979), where a greywacke lithic fragment is crosscut by wairakite and epidote veins. This degree of alteration is not present in the rest of the lithic population or in the matrix.

\subsubsection{Karaponga Formation: welded ignimbrites}

Karaponga Formation consists of deposits from explosive rhyolitic volcanism that occurred outside of the Kawerau area around 0.5 to 0.6 Ma. Three discrete, partially welded ignimbrites in this formation have been dated by U-Pb techniques on zircon (Milicich et al., 2013a), with estimated eruption ages of $0.60 \pm 0.05 \mathrm{Ma}(\mathrm{KA} 48,-477 \mathrm{mRL}), 0.57 \pm 0.02 \mathrm{Ma}$ (KA21, -747 $\mathrm{mRL})$ and $0.51 \pm 0.02 \mathrm{Ma}(\mathrm{KA} 17,-559 \mathrm{mRL})$. The oldest unit is crystal-rich with embayed quartz (some are bipyramidal) and plagioclase, and also lithic-rich (rhyolite and andesite rock fragments). The youngest unit is petrographically similar, but also contains altered biotite crystals.

The middle unit (Fig. 3.7A) is petrographically indistinguishable to the youngest unit, but is linked on the basis of age data, similarities in cathodoluminescence (CL) zircon textures and host-rock textures to the 'Quartz-biotite Ignimbrite' of Nairn (2002) and Cole et al. (2010), ${ }^{40} \mathrm{Ar} /{ }^{39} \mathrm{Ar}$ dated at $0.557 \pm 0.003 \mathrm{Ma}$ by Leonard et al. (2010). This ignimbrite crops out to the southwest of Kawerau and it is also represented by reworked material in fluvial outwash sequences on the Bay of Plenty coast, overlying a voluminous co-eruptive fall deposit. This deposit is inferred to have been erupted from a source, now buried, beneath the modern Okataina volcano (Cole et al., 2010). Neither of the bracketing ignimbrites from this study has been correlated with surficial sequences. 


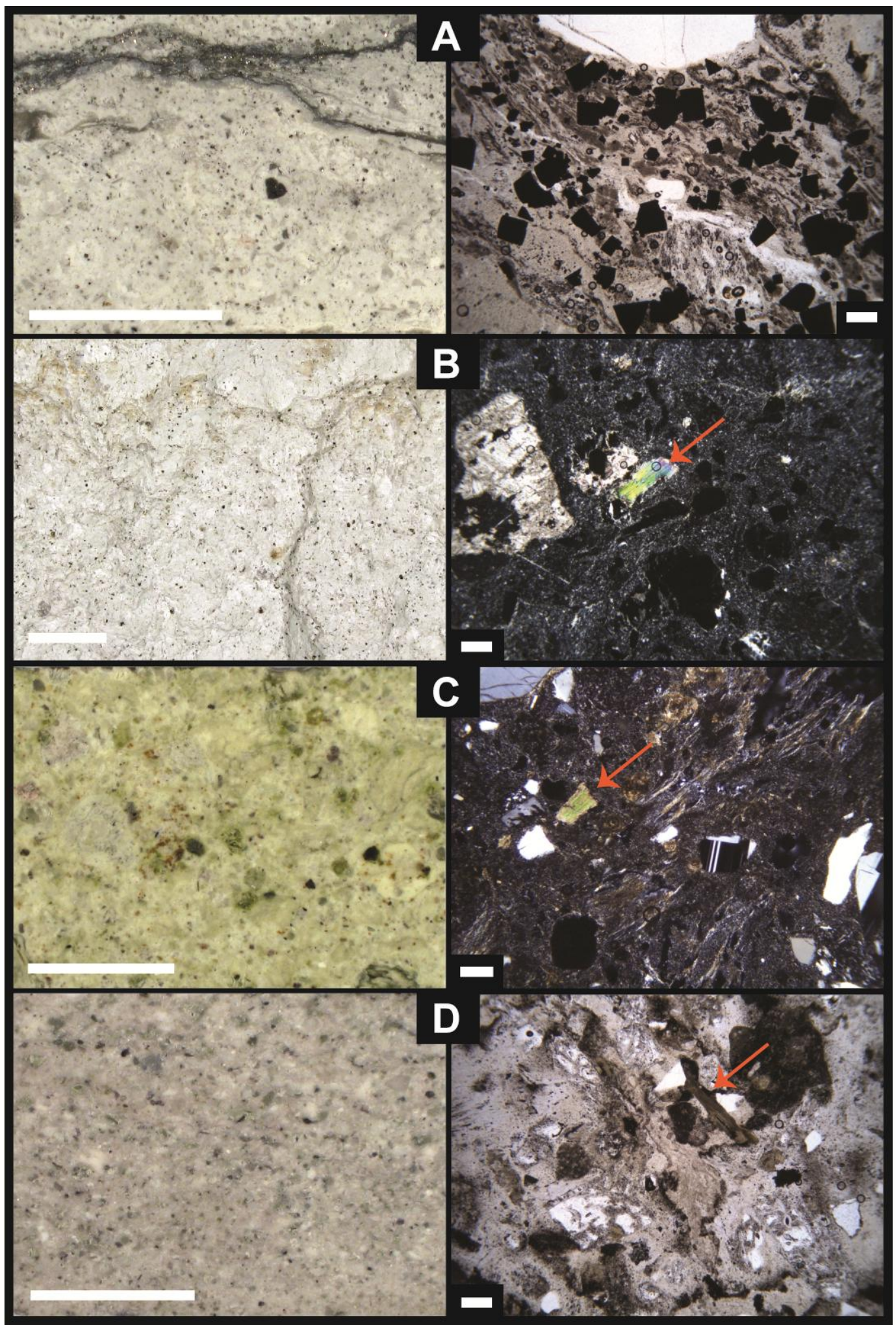

Figure 3.7 Examples of hydrothermally altered ignimbrite at Kawerau. Images on the left are hand specimen, with the scale bar indicating $1 \mathrm{~cm}$ in all images. Images on the right are photomicrographs of thin sections, with the scale bar indicating $200 \mu \mathrm{m}$ in all images. Biotite pseudomorphs are indicated with an arrow. A) KA21 -747 mRL. Karaponga Formation (0.57 Ma). Groundmass is highly altered, with primary volcanic texture obscured. Flattened pumices are obvious in thin section, with pyrite preferentially growing in pumice clasts. B) KA26 -426 mRL. Raepahu Formation (1 $\mathrm{Ma}$ ). Alteration overwhelms the primary textures, though biotite pseudomorphs are clear in thin section. C) PK1 -576 mRL. Te Teko Formation (1.46 Ma). Eutaxitic texture in the vitroclastic groundmass is preserved. D) KA21 $-880 \mathrm{mRL}$. Te Teko Formation. The eutaxitic texture present in image $\mathrm{C}$ ) is not obvious here, with alteration obscuring groundmass textures. 


\subsubsection{Onerahi Formation: sediments}

Rocks of this formation were previously included in the Huka Falls Formation (Grindley, 1986; Allis et al., 1995) although none of these materials can be an age or lithological correlative of the Huka Falls Formation in its type area at Wairakei Geothermal Field (Grindley, 1965). The Onerahi Formation is dominantly composed of tuffaceous to muddy breccias and coarse tuffaceous sandstone (Fig. 3.6E), and occurs sporadically below the partly welded ignimbrites of the Karaponga Formation. Bracketing $\mathrm{U}-\mathrm{Pb}$ age determinations $(0.60$ Ma above (Karaponga Formation), 1.0 Ma below (Raepahu Formation)) imply that the formation does not represent a long period, but was deposited during a period where there was little influx of felsic volcanic material, coinciding with the time when the Kawerau Andesite was erupted.

\subsubsection{Kawerau Andesite}

The Kawerau Andesite (Fig. 3.5) forms a northwest-southeast elongated body in the central and northwestern part of the field, and consists of multiple lava flows and tuff (Bogie, 1981) at $\sim 600-1000 \mathrm{~m}$ depth. The andesite thickens toward an inferred vent zone in the northwest part of the field (Allis et al., 1995), which is consistent with interpretations from past magnetic surveys (Macdonald and Muffler, 1972). Many wells in the field produce from fracture permeability in the Kawerau Andesite (Allis et al., 1995), particularly in KA8, KA35 and KA37 where the andesite is cut by faults, and maximum well temperatures tend to be located in these zones (Healy, 1974). In parts of the field, andesite flows are intercalated with pyroclastic units, implying either episodic emplacement or a partly intrusive origin. Red-brown friable material present in KA23, KA25, KA26 and KA34 was interpreted by Browne (1978a) to be correlative andesitic tuff, but we infer that these intervals are contemporaneous with the Te Teko Formation and are thus older.

\subsubsection{Raepahu Formation: ignimbrites}

The Raepahu Formation (Edbrooke, 2005) comprises deposits from two eruptions that are close to $1 \mathrm{Ma}$ in age, namely the Kidnappers ignimbrite and younger Rocky Hill ignimbrite (Martin, 1961; Houghton et al., 1995; Wilson et al., 1995b). The Raepahu Formation at Kawerau is inferred to be represented by ignimbrite units with $\mathrm{U}-\mathrm{Pb}$ ages clustered around 1.0 Ma. These predominantly occur beneath the (undated) Kawerau Andesite, but also below sediments of the Onerahi and Tahuna formations (see Appendix A). 
Sample KA23, $-246 \mathrm{mRL}(0.95 \pm 0.05 \mathrm{Ma})$ is correlated directly with the Kidnappers ignimbrite, on the basis of a similar age spectrum present in published and unpublished $\mathrm{U}-\mathrm{Pb}$ age data (Wilson et al., 2008; Milicich et al., 2013a) and primary mineralogy, including the occurrence of altered biotite. The Kidnappers ignimbrite has limited extent within the Kawerau Field, occurring only in KA23, KA45, KA46 and KA30 (Fig. 3.2), suggesting local topographic relief has channelled its deposition.

An ignimbrite sampled in KA26, -426 mRL (0.98 \pm 0.04 Ma from core) and KA48, -747 mRL $(1.00 \pm 0.03 \mathrm{Ma}$ from cuttings) has similar age characteristics within uncertainties, but is differentiated from the Kidnappers ignimbrite on the basis of petrography and is not directly correlated with any named surficial ignimbrite. It is generally lithic-rich and crystal-poor, with quartz (often embayed and bipyramidal), plagioclase, altered ferromagnesian minerals including rare biotite only (Fig. 3.7B). This lower ignimbrite is widespread across the field, suggesting that it spread across an area of low topographic relief. The relationship between this ignimbrite and that correlated with the Kidnappers ignimbrite is unknown as there are no wells in which both deposits occur. It is possible that they represent contrasting lithofacies of a single composite unit, linked to the Kidnappers/Rocky Hill eruptions.

\subsubsection{Tasman Formation: sediments}

The Tasman Formation consists of a sequence of sedimentary units that overlie the Te Teko Group, including sediments previously logged by Browne (1978a) and Grindley (1986) as Huka Falls Formation and 'Tasman Breccia' (Table 3.1). The Tasman Formation includes muddy breccia, sandstone and siltstone, and is widely represented by a thin ( $5-20 \mathrm{~m}$ thick) interval of reddish brown fine-grained sediments (Fig. 3.6D). This fine-grained material is inferred to represent a significant break in time and the development of a palaeosol (or reworking of a weathered surface from higher ground elsewhere). The Tasman Breccia of Browne (1978a) and Grindley (1986) contains rhyolite lava, pumice, ignimbrite, rare greywacke, basalt and granophyre clasts, and crystal fragments. Browne (1978a) suggested that the Tasman Breccia may be a hydrothermal eruption breccia, and precede volcanic activity from the Okataina Volcanic Centre. However, the relative age of this unit below the $1.0 \mathrm{Ma}$ Raepahu Formation means it predates any proposed activity at Okataina (Cole et al., 2010). In addition, there is no evidence of clasts with pre-existing hydrothermal alteration out of equilibrium with the current alteration, and we thus conclude that the Tasman Breccia is not hydrothermal in origin. 


\subsubsection{Te Teko Formation: ignimbrites and sediments}

All volcaniclastic and minor sedimentary units stratigraphically below the Tasman or Raepahu formations, and above the deposits of the Tamurenui Subgroup, are collectively referred to as Te Teko Formation that overcomes ambiguities in previous works. Whilst earlier stratigraphic field models (e.g. Grindley, 1986) formally named various stratigraphic intervals as the Te Teko and Opunoke ignimbrites, detailed petrographic studies and stratigraphic correlations (Milicich, 2013a,b; Milicich et al., 2013a) show that these terms have been inconsistently applied. Throughout most of the field, the Te Teko Formation is represented by a single ignimbrite with an estimated eruption age of $1.46 \pm 0.01 \mathrm{Ma}$ based on six independent age determinations (KA25; -677 mRL, KA26; -545 mRL, PK1; -578 mRL, KA21; -880 mRL, and KA37; -1078 mRL: Milicich et al., 2013a). The ignimbrite has a well-developed eutaxitic texture with a vitroclastic groundmass (Fig. 3.7C), common lithics of tuff, greywacke, and rhyolite lava (some spherulitic), and phenocrysts of embayed quartz, plagioclase and rare to minor biotite.

In drillhole KA23, two ignimbrites are present in the Te Teko Formation, separated by $25 \mathrm{~m}$ of sediments and/or palaeosols. The upper ignimbrite returns an eruption age estimate of 1.34 $\pm 0.04 \mathrm{Ma}$ (Milicich et al., 2013a), consistent with it being a discrete unit, although identified only in drillholes KA23, KA45 and KA46 (Fig. 3.2). The lower ignimbrite returns an eruption age of $1.46 \pm 0.01 \mathrm{Ma}$ (Milicich et al., 2013a). The younger ignimbrite is variably lithic and crystal-rich, with quartz and plagioclase \pm biotite and altered ferromagnesian minerals. Lithics comprise spherulitic rhyolite lava, andesite, tuff, tuffaceous sandstone and greywacke. The younger ignimbrite is part of a sequence with several distinguishable units (see Appendix A), which could imply the presence of either a single compound ignimbrite, or several deposits at intervals too closely spaced to discriminate by age dating and lacking sufficient time to develop a significant weathering horizon.

\subsubsection{Tamurenui Subgroup (Rotoroa and Waikora formations)}

Below the Te Teko Formation (i.e. prior to $1.46 \mathrm{Ma}$ ), there are no major individual marker horizons identified in Kawerau drillholes that can be correlated across the Kawerau Field. Several lithologies separate the Te Teko Formation from greywacke basement, including sandstone, siltstone, greywacke conglomerate and tuff, defined by previous workers as Waikora Formation (Browne, 1978a; Grindley, 1986). In TVZ geothermal fields, the term Waikora Formation is typically applied only for greywacke pebble conglomerates (e.g. Gravley 
et al., 2006; Bignall and Milicich, 2012), including at Kawerau where it is up to $\sim 450 \mathrm{~m}$ thick in KA44. There are drillholes at Kawerau, however, where the relevant sedimentary intervals are predominantly siltstones (e.g. KA23). To avoid confusion, all sedimentary (and minor volcaniclastic) strata underlying the Te Teko Formation and overlying the greywacke basement has been renamed Tamurenui Subgroup. The term Waikora Formation, within the Tamurenui Subgroup is retained exclusively for intervals dominated by greywacke conglomerate (Fig. 3.6F), consistent with usage of the term in other TVZ geothermal fields (Gravley et al., 2006; Rosenberg et al., 2009), although minor fine-grained sediments are still present (Fig. 3.6A, C). All other sedimentary lithologies (including minor pyroclastic deposits) are renamed Rotoroa Formation. Within the Rotoroa Formation, plant remains (similar to Fig. 3.6A) are locally present (e.g. KA34), consistent with terrestrial deposition (no marine sediments have been identified in rocks assigned to this unit).

Two thin $(<15 \mathrm{~m})$ pyroclastic units in the Rotoroa Formation have been dated (Milicich et al., 2013a). In KA25 (-796 mRL), a $2.17 \pm 0.05$ Ma pumice-bearing, eutaxitic tuff contains common crystals of embayed quartz, plagioclase, ferromagnesian minerals and biotite and has minor lithics of rhyolite lava (some spherulitic) and greywacke. In KA34 (-707 mRL), a $2.38 \pm$ 0.05 Ma pumice-bearing ignimbrite occurs with common crystals of plagioclase, quartz and minor biotite, and minor lithics of rhyolite and andesite lava, tuff and greywacke. The groundmass, although highly altered, still has visible a vague vitroclastic texture. Both ignimbrites are inferred to be sourced from the southern Kamai area, near Tauranga, on the basis of their ages and petrographic observations (Briggs et al., 2005; Milicich et al., 2013a).

\subsubsection{Basement greywacke}

The basement greywacke at Kawerau is important in hosting the major faults and fractures that facilitate flow of high-temperature fluids into the overlying Quaternary succession. In the northern TVZ, there is a major boundary between the Waipapa and Torlesse composite terranes close to the Kawerau area (Mortimer, 1995; Adams et al., 2009; Leonard et al., 2010). The greywacke at Kawerau is mainly a medium-grained sandstone dominated by subangular volcanic clasts (mainly andesite lava, rare rhyolite lava and ignimbrite), with minor argillite and chert (Wood et al., 2001). There is, however, ambiguity in the categorisation of the Kawerau greywacke. Wood et al. (2001) classified the greywacke at Kawerau as belonging to the Waioeka (petro-) facies of the Pahau terrane (i.e., part of the Torlesse composite terrane: Leonard et al., 2010). In contrast, on the same lithological basis, Adams et al. (2009) assigned the greywacke to the Waipapa composite terrane, and linked it to greywacke exposed at the 
ground surface $\sim 30 \mathrm{~km}$ to the northwest of Kawerau.

The sheared greywacke basement is inferred to be down-faulted to the northwest. Greywacke has been drilled at Kawerau at depths ranging from $-667 \mathrm{mRL}$ in the southeast, i.e. in KA29, on the upfaulted eastern margin of the Whakatane Graben, to $-1268 \mathrm{mRL}$ on the northwest margin of the field, i.e. in KA17 (Milicich, 2013b; Electronic Appendix 1).

\subsection{DISCUSSION}

The chronostratigraphic perspectives offered by new U-Pb age data (Milicich et al., 2013a), combined with a consistent suite of petrographic observations (Milicich, 2013a; Electronic Appendix 2) enable a rigorous view on geological development of the Kawerau geothermal system and allow it to be placed in a broader context within the volcanic and structural evolution of the central TVZ. For any economically viable high-temperature geothermal system, the requirements are for a heat source, permeability pathways and fluid, but given that those are present at the modern TVZ systems, other questions can be addressed.

(a) Are the modern TVZ systems long-lived and fixed in space, such that even major volcanic disruption or burial does not affect their deep roots, are they short-lived, and inferred to have shifted as the locus of thermal input changes?

(b) Do geothermal systems maintain their thermal outputs in a steady state, buffered by the thermal capacity of the shallow $(<3 \mathrm{~km})$ heated rock mass for long time periods $\left(10^{5}\right.$ years or more), or do systems arise then dissipate as subsurface magmatic sources wax and wane?

Models and observations, particularly those that consider the spacing between systems versus depth to the base of the TVZ seismogenic zone, and the relative scarcity of geophysical or geological evidence for relict feeder zones (e.g., McNabb, 1975; Bibby et al., 1995; Kissling and Weir, 2005; Dempsey et al., 2011, 2012; Rowland and Simmons, 2012) imply that many TVZ systems are both fixed and long lived. In subsequent discussion we use new age data and insights into stratigraphic controls to re-consider the evolution of the Kawerau geothermal system. 


\subsubsection{Local magmatism}

A feature of the Kawerau geothermal system, common to all the systems in the TVZ, is that the dominant volumes of rock penetrated by drilling are derived from sources outside the respective system. Only coherent lavas and intrusive rocks provide direct evidence for magmatism existing now or in the past at depth beneath a system (e.g., Arehart et al., 2002) that will have supplied heat. Rocks derived from distal sources can provide permeable hosts, but at Kawerau are passive faulted markers, and are not the primary production targets for geothermal drilling. In contrast, fractured greywacke basement at Kawerau is more important as it hosts fractures and fault conduits for geothermal fluids.

There is evidence for four, possibly five periods when magma was present beneath the Kawerau area, based on presence of locally vented extrusive rocks, listed chronologically.

(a) Putanaki-Mt Edgecumbe. The conceptual model of the modern Kawerau geothermal system (Bignall and Milicich, 2012) has deep-derived hot fluids moving upwards through basement greywacke via widely spaced, steeply dipping faults and/or fractures of high local permeability, within otherwise largely impermeable rock. The faults are predominantly northeast-striking normal faults with cross-cutting northwest-striking faults. The highest measured well temperatures (up to $310^{\circ} \mathrm{C}$ ) occur in the southern part of the Kawerau Geothermal Field and (along with fluid chemistry) points to a deep heat source for the system in the area towards Putauaki volcano (Christenson, 1997; Bromley, 2002). The youthful age and composite construction of Putauaki is consistent with the presence of a magma reservoir or hot pluton that thermally supports the modern system (Allis et al., 1995; Bignall and Milicich, 2012). Hydrothermal eruption breccias in eastern parts of the field (of $\sim 16 \mathrm{ka}$ and $\sim 9 \mathrm{ka}$ age) demonstrate intense hydrothermal activity was occurring at shallow levels at those times and we relate these hydrothermal eruption breccias to intrusion of magma associated with the onset of Putauaki magmatism. There is little present day surface hydrothermal activity in the eastern borefield, with wells KA25 and KA26 encountering relatively low temperatures $\left(<200{ }^{\circ} \mathrm{C}\right)$ to 800 and $480 \mathrm{~m}$ depth respectively, although both have recorded high temperatures $\left(>280{ }^{\circ} \mathrm{C}\right)$ in impermeable basement sections of the wells. Both wells are non-producing due to low permeability (Christenson, 1997).

(b) Onepu Formation. The surficial Onepu domes and their feeder dikes are inferred to represent a single isolated event, based on age data (Milicich et al., 2013a, Fig. 3.3), and 
thus may not have been accompanied by any significant or sustained thermal pulse at the surface.

(c) Caxton and Tabuna formations. The rhyolite lavas and intrusions of the Caxton Formation, plus the slightly older locally sourced pyroclastic rocks of the Tahuna Formation provide evidence for a shallow magma body beneath the Kawerau area between at least 0.43 and 0.36 Ma. Browne (1979) inferred a lithic lapilli tuff in drillhole KA25 (-444 to $-464 \mathrm{mRL}$ ) beneath the Matahina ignimbrite was associated with a hydrothermal eruption breccia.

From our work, we now place the sample in volcanic tuffs of the Tahuna Formation, beneath the extrusive Caxton Formation rhyolites. Browne (1979) took the presence of the hydrothermal eruption deposit to infer the Kawerau system has been active for at least since that time (given as $>0.20 \pm 0.03 \mathrm{Ma}$, based on a fission-track age estimate for the Matahina ignimbrite reported as a personal communication to P.R.L. Browne from B.P. Kohn). Browne (1979) did state very little was known about changes in the magnitude of hydrothermal activity during this time and that temperatures, permeabilities and fluid compositions are likely to have fluctuated. Our work suggests that this early hydrothermal activity reflects heat flow associated with the Tahuna and Caxton formation rhyolites, and would suggest that there is no link to the heat source fuelling the modern system. Neither the volumes of magma represented by the Caxton rhyolites $\left(\sim 1 \mathrm{~km}^{3}\right)$, nor the total volume of magma inferred to have generated the rhyolites by assimilation/fractional crystallization $\left(\sim 10 \mathrm{~km}^{3}\right)$, is inferred to have been sufficient to feed an active geothermal system for periods of the order of $10^{2}$ to $10^{4}$ years (e.g. Cathles, 1977).

(d) Pre-Tabuna Formation magmatism? A period of magmatism at about $0.55 \pm 0.05 \mathrm{Ma}$ is suggested by the ages of inferred inherited zircons present in the Caxton and Onepu formations and associated tuffs. These older grains cannot be accidental inclusions from the Karaponga Formation as they occur in coherent rhyolite intrusions that are stratigraphically below the Karaponga Formation. These observations suggest that there may be intrusions of comparable age to the Karaponga Formation ignimbrites at depths beyond those currently reached by drilling.

(e) Kawerau Andesite. The Kawerau Andesite, with bracketing ages of 0.60 and $1.0 \mathrm{Ma}$, is the oldest unit giving evidence of magmatic activity beneath the Kawerau system. It is unlikely, however, that the magmatism from which the Kawerau Andesite derived 
fuelled a geothermal system, as andesite composite cones of similar dimensions in the TVZ tend to not have large or long-enough lived magmatic sources at shallow depths to fuel geothermal systems (e.g. Rolles Peak, Pihanga). The modern field, driven by magmatism in the Putauaki area is a clear exception to this and is unusual in this sense, but may be explained by the more-evolved compositions (andesitic to dacitic) of its lavas and its prolonged activity reflecting a shallow-level magma system.

Of these five identified episodes of local magmatism, only those associated with the latest Quaternary Putauaki and the $0.43-0.36 \mathrm{Ma}$ Tahuna/Caxton systems have left clear influence on the hydrothermal system. Between these episodes we suggest that the area was hydrothermally quiescent, and that the Kawerau geothermal system as it appears today (i.e. with respect to the nature of its surface manifestations, size, depth to reservoir and chemistry of its reservoir fluids) is only $\sim 16$ kyr old.

\subsubsection{Distal volcanism}

In contrast to the local magmatism represented by coherent rhyolite and andesite bodies beneath the field, much of the primary rhyolitic pyroclastic fall and flow deposits intersected by drilling in the Kawerau area are derived from distal sources. The volcaniclastic sediments, ash fall and ignimbrite units "cap" the system, which is mostly hosted within the greywacke basement, and provide important marker planes across the field that have helped to resolve the structural and depositional history of the area. Deposition of significant thicknesses of ignimbrite within the Kawerau area was episodic (Milicich et al., 2013a). While ignimbrite members of the Karaponga and Raepahu formations are inferred to be correlatives of the 'Quartz-biotite ignimbrite" and Kidnappers ignimbrite respectively, ignimbrites of the Te Teko Formation do not correlate with any known (dated) surficial TVZ ignimbrites, and their source is unknown. Their time equivalents, specifically the deepest of the major tuff units ('Paeroa C') intersected in drillhole WT7 (WT701), have been identified at Waiotapu Geothermal Field, $45 \mathrm{~km}$ southwest of Kawerau (Wilson et al., 2010). These deeply buried ignimbrites have no surficial equivalent, and correspond to a period of tephra accumulation occurring in the marine record off the east coast of the North Island (Carter et al., 2003, 2004; Allan et al., 2008; Milicich et al., 2013a) and in the Wanganui Basin (Pillans et al., 2005).

The Karaponga Formation represents a period of intense volcanism which produced a number of ignimbrite forming events from 0.60 to 0.51 Ma (Milicich et al., 2013a). One of these ignimbrites has been correlated by us with the Quartz-biotite Ignimbrite inferred by 
Nairn (2002) and Cole et al. (2010) to have been erupted from a source at Okataina volcano $20 \mathrm{~km}$ to the southwest of Kawerau, and hence other ignimbrites in the $0.5-0.6 \mathrm{Ma}$ interval are likely to have been vented from the Okataina area.

Previously (e.g. Browne, 1978a; Grindley, 1986), the term 'Rangitaiki Ignimbrite' was applied to several horizons in the Kawerau Geothermal Field. These rocks we now assign to the Karaponga, Raepahu and Te Teko formations. The Rangitaiki is one of the large ignimbrites of the Whakamaru group, erupted at $0.349 \pm 0.004 \mathrm{Ma}\left({ }^{40} \mathrm{Ar} /{ }^{39} \mathrm{Ar}\right.$ date from Downs et al., 2013b) from a source at least $80 \mathrm{~km}$ southwest of Kawerau (Wilson et al., 1986; Brown et al., 1998). The petrography of several ignimbrites in the Kawerau system (as well as the outcropping Rangitaiki ignimbrite outside of the Kawerau area) are superficially similar: crystal-rich, with large primary crystals of, or pseudomorphs after, quartz, plagioclase and biotite. Due to these similarities, samples from what we name the Karaponga, Raepahu and Te Teko formations had been previously correlated with the Rangitaiki ignimbrite (Browne, 1978a; Tulloch 1990; Allis et al., 1995). Browne (1978a) and Tulloch (1990) divided the 'Rangitaiki ignimbrite' at Kawerau into 'upper', 'lower' and 'crystal-rich' subunits, on the basis of welding and crystal content. There was no definitive cross-correlation from these 'Rangitaiki units' to the units described in this paper (Table 3.2), and intervals in several wells attributed to the Rangitaiki ignimbrites are now known to be considerably older than the Whakamaru group of ignimbrites, and have been dated at 0.6, 1.0 and $1.45 \mathrm{Ma}$ (Milicich et al., 2013a). The absence of the Rangitaiki ignimbrite could reflect the fact that its flows did not reach this distance from source or, that due to the presence of topographic relief of the Caxton rhyolite domes, the flows were diverted around the Kawerau area.

\subsubsection{Sediments and their significance}

Many of the sediment-rich intervals in the Kawerau Field were previously allocated to the Huka Falls Formation of the Huka Group (Grindley, 1965; Rosenberg et al., 2009). Where first defined at Wairakei (Grindley, 1965), the Huka Falls Formation is dominantly lacustrine in origin, but the term has since been used generically for all sedimentary units within the TVZ. The term Huka Group was used by Grindley (1986) for sedimentary intervals between 400 and $700 \mathrm{~m}$ depth below ground level in drillholes throughout the Kawerau Field, with indirect correlations proposed with similar deposits at Wairakei. However, the Huka Falls Formation at Wairakei post-dates the Whakamaru group ignimbrites and therefore cannot be the time equivalent of the sediment-dominated formations at Kawerau. Grindley (1965) also correlated the Huka Falls Formation with marine and terrestrial sediments at Matata on the 
Bay of Plenty coastline which are now known to incorporate tephras equivalent in age to the Karaponga Formation at Kawerau (Hikuroa et al., 2006; Milicich et al., 2013a). The correlations proposed by Grindley (1986) are not compatible with the new data, and these sediments at Kawerau have been reassigned as Tahuna, Onerahi and Tasman formations depending on their stratigraphic correlations.

The Tamurenui Subgroup sediments record early basin development in the Kawerau area. The presence of thick greywacke gravels (Waikora Formation), particularly in the north and northeast parts of the field indicate development of significant topographic relief nearby, presumably related to early uplift of the axial greywacke ranges east of Kawerau, and development of gravel-choked rivers analogous to the modern Rangitaiki River (Fig. 3.1). Regional uplift of the ranges only occurred after emplacement of the $1.0 \mathrm{Ma}$ Kidnappers ignimbrite to sites on the Pacific coastline (Yoshikawa, 1993; Coleman et al., 2001), and localised uplift displaced the Matahina ignimbrite east and west of the active Whakatane Graben (Bailey and Carr, 1994; Hikuroa et al., 2006).

The accommodation basins infilled by the Waikora Formation greywacke gravels at Kawerau are inferred to be related to dominantly strike-slip faulting, rather than normal faulting, because the relatively even distribution of succeeding ignimbrites of the Te Teko Formation implies a lack of significant topographic relief before 1.5 Ma. Movement on these faults dropping down to the northwest created the accommodation space required for the infilling by the Waikora gravels. The Waikora gravels thin to the southwest and are coeval with the Rotoroa Formation, which consists dominantly of fine-grained sediments (sands, silts) and inferred associated palaeosols. Many of these sediments contain carbonaceous material and leaf imprints, indicating a terrestrial depositional environment, likely marginal to a river system that was depositing the gravels. Non-welded ignimbrites and other tuffaceous units are incorporated within the Rotoroa Formation, and to a lesser degree within Waikora Formation gravels, and provide evidence that faulting and sedimentation began prior to $2.38 \pm 0.05 \mathrm{Ma}$. Two periods of fault activity, the first ceasing around $2.5 \mathrm{Ma}$, the second starting around 1.5 Ma have been documented in faults east of the Whakatane Graben (Mouslopolou et al., 2007, 2008) as well as in the North Island Shear Belt in the axial ranges $200-300 \mathrm{~km}$ south of Kawerau (Erdman and Kelsey, 1992; Beanland et al., 1998). Our observations at Kawerau are consistent with these studies and so the faulting associated with accumulation of the Waikora Formation gravels contribute to the understanding of the regional events.

Sediments in the Kawerau area are mostly coarse grained breccias and sandstones interbedded with siltstones, which in all but one case (the Tahuna Formation in KA22) are inferred to 
reflect a terrestrial depositional environment. The Kawerau sedimentary sequences contrast with those at Matata (Fig. 3.1) where there are alternating marine and terrestrial sediments (Hikuroa et al., 2006), correlated by us as time equivalents of the Tahuna and Karaponga formations. Our inference is that the sedimentary environment at Kawerau has almost always been similar to the present day. This involves fluvial systems feeding coarse sediments from uplifted inland catchments, and areas of finer-grained deposition in swamp-like or lacustrine environments, as evidenced by the fine-grained carbonaceous deposits, rich in leaf-imprints. The rate of sedimentation and infill by volcanic deposits is inferred to have been similar to the rate of subsidence, such that marine conditions only once demonstrably reached inland to Kawerau (currently $\sim 23 \mathrm{~km}$ from the coast and $\sim 30 \mathrm{~m}$ above modern sea level).

\subsubsection{Faulting and subsidence}

Geothermal drilling indicates the main lateral permeability is located towards the north of the Kawerau Field, where it is controlled by the location of active faults and fracture networks. Faults are present in the south, but these are likely inactive, and sealed by hydrothermal mineral deposition (Christenson, 1997). A northwest-striking fault at Putauaki may be a major pathway for fluid upflow in the vicinity of the volcano, with waters leaking into the present borefield area via northwest-striking faults that are intersected by northeast-trending (regional) structural features (Bignall and Milicich, 2012). Resistivity data, combined with the inferred location of the main heat source (based on well productivities and downhole temperature surveys, southern wells reach up to $310^{\circ} \mathrm{C}$ ) and mass outflow, is consistent with deeply-sourced thermal fluids flowing from the south to north within the production borefield, with progressive dilution and cooling of the geothermal fluid as it mixes with groundwater (Bromley, 2002; Bignall and Milicich, 2012). The lineaments of these two faults can be traced through the structural development of the system, and is visualised using a 3-D geological representation of the field (Fig. 3.8). The relative timing of fault activation is shown in cross section in Fig. 3.9. 


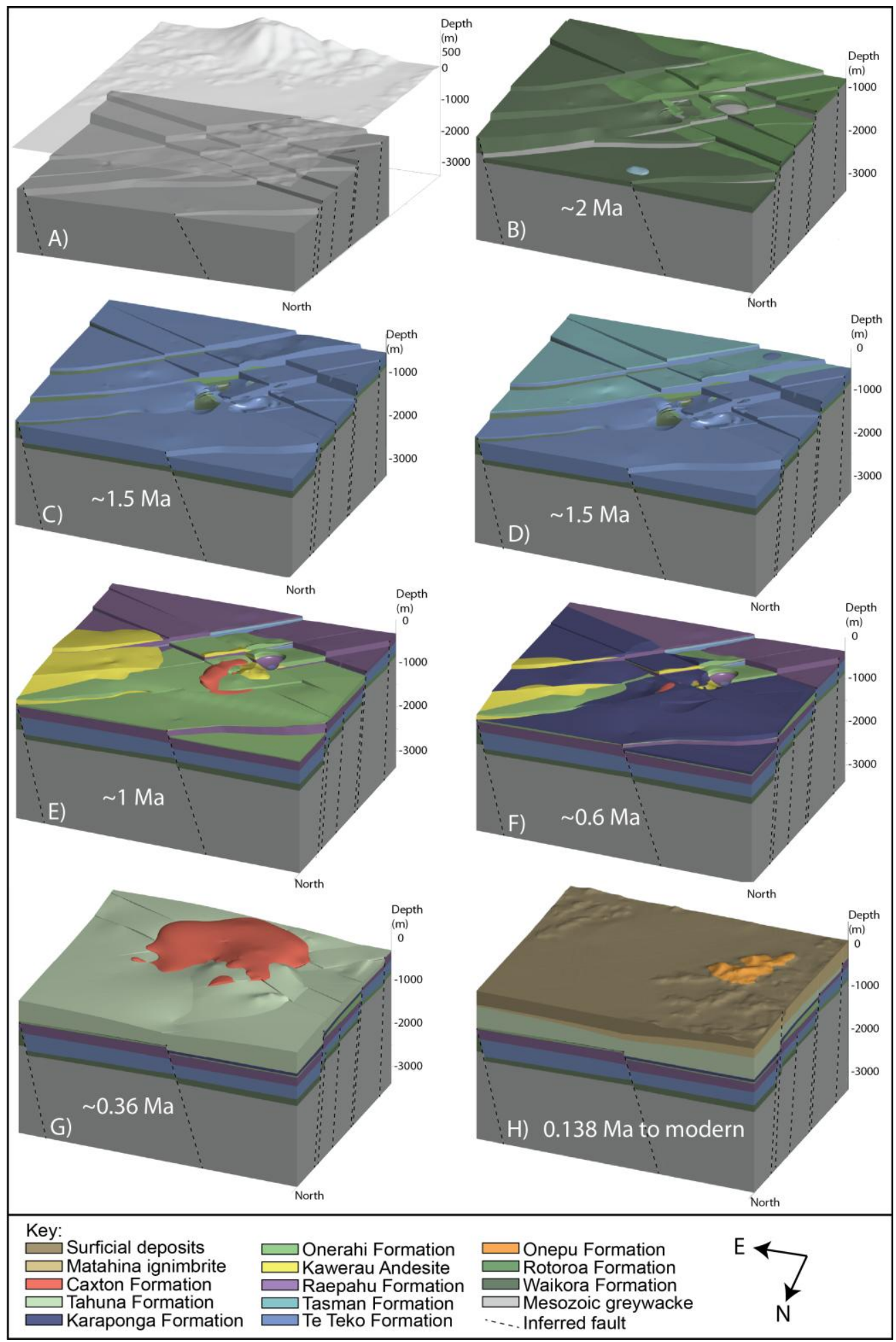

Figure 3.8 3-D geological representation of the Kawerau geothermal system, with the development of structure and stratigraphy through time. Note, this is stripping back the stratigraphy, not an indication of landscape at that time. A) NW-SE and NE-SW TVZ structural grain and are evident in the greywacke basement. B) Deposition of the Waikora and Rotoroa formation sediments is related to the NW-SE structures. C) Uniform thickness of the Te Teko Formation indicates little topographic relief was present at the time of deposition. D) The Tasman Formation sediments and palaeosols occur only in the southeast of the field. E) The Raepahu Formation was deposited along structures mostly in the NW part of the field, roughly aligning with the modern NE-SW TVZ grain, infilling topographic relief. The Onerahi Formation sediments thicken to the NW, infilling down-faulted structures in this direction. F) By the time of emplacement of the Karaponga Formation, the dominant rifting NE-SW structures of the TVZ have mostly been buried. G)-H) By emplacement of the Tahuna and Caxton formations, through to the modern situation, the only remaining active faults in the area are the Onepu and Rotoitipaku Faults in the NW of the area. 
The northwest-southeast basement structures at Kawerau (Fig. 3.8A) are high angle with respect to the modern TVZ structural grain, predate $1.5 \mathrm{Ma}$ and are related to deposition of the Waikora and Rotoroa formation sediments (Fig. 3.8B). Before emplacement of the $\sim 1.5$ Ma ignimbrites there was little remaining topographic relief as the Te Teko Formation is relatively uniform in thickness across the field (Fig. 3.8C). This formation is thus used as a marker plane to infer the timing and magnitude of faulting in the field. Subsequent deposition of sediments and associated palaeosols of the Tasman Formation occurred in the southeast of the field (Fig. 3.8D) after emplacement of the Te Teko Formation ignimbrites over a $\sim 0.35$ Myr period.

The Raepahu Formation (Fig. 3.8E) was deposited at $\sim 1$ Ma mostly in the northwest part of the field, along structures that provide the earliest evidence of faults that roughly align to the modern northeast-southwest TVZ structural grain. The Raepahu Formation is not a uniform thickness across the field, indicating it has infilled topographic relief created either by faulting or valley erosion. Following emplacement of the Raepahu Formation ignimbrites, these earlyforming northeast-southwest TVZ rift related faults became the dominant structural control in the Kawerau area, and probably controlled the position of the Kawerau Andesite feeder zone. The sediments of the $1.0-0.6 \mathrm{Ma}$ Onerahi Formation (Fig. 3.8E) thicken to the northwest, infilling down-faulted structures in this direction.

By 0.6 Ma, and emplacement of volcanic units of the Karaponga Formation, the rifting northeast-southwest structures of the TVZ were no longer dominant in the Kawerau area (Fig. 3.8F). It is not clear whether there was migration of the active rift to the west (e.g., from the presence of fluvial greywacke gravels in the $\sim 0.6 \mathrm{Ma}$ Matata sedimentary sequences west of the $\sim 300 \mathrm{~m}$ high scarp marking the western edge of the modern TVZ in the Whakatane Graben: Hikuroa et al., 2006; Leonard et al., 2009), or a general cessation of rifting over a wider part of the TVZ. The latter is possibly indicated by the paucity of regionally distributed large ignimbrites erupted between 0.71 and $0.35 \mathrm{Ma}$ (Houghton et al., 1995; Leonard et al., 2010). By $\sim 0.4 \mathrm{Ma}$, and emplacement of the Tahuna and Caxton formations, through to the present day (Fig. 3.8G, H), the only known active faults in the area are the Onepu and Rotoitipaku faults (Fig. 3.2).

Accompanying the apparent lack of active rifting in the Kawerau area, magma generation under the field has resulted in emplacement of sills and domes of the Caxton Formation (Fig. 3.5). We envisage two influences as a result of the lack of active rifting. First, a lack of active faulting may have acted to inhibit flow of magma to the surface, with the result that magmas stalled in the crust and evolved to rhyolite. Second, in a stress state where the minimum 
principal stress axis $\left(\sigma_{3}\right)$ would have been vertically orientated, intrusion of magma as sills, rather than continuous dikes, would have been favoured. In the Kawerau area, the change in stress state from $\sigma_{3}$ vertical to horizontal and orientated northwest-southeast perpendicular to the structural grain of the TVZ (Rowland and Sibson, 2001; Rowland et al., 2010), occurred at some stage after $0.36 \mathrm{Ma}$ and before $0.138 \mathrm{Ma}$ when the dike-fed Onepu Formation domes were erupted (Fig. 3.5). Evidence from sediments exposed at Matata (23 km north of Kawerau) indicate a change from subsidence to strong uplift $(\sim 3 \mathrm{~mm} / \mathrm{yr}$ average $)$ in the eastern Bay of Plenty at $\sim 370 \mathrm{ka}$ (based on ${ }^{40} \mathrm{Ar} /{ }^{39} \mathrm{Ar}$ ages of interbedded tephras; Leonard et al., unpublished data; Leonard et al., 2009). This change reflected the onset of uplift of the western and eastern shoulders of the present-day Whakatane Graben (Mouslopolou et al., 2007,2008 ) and development of the present-day highly active rifting.

Cumulative rates of fault movement determined from offsets for the top of units show the northeast-southwest faults have accumulated more fault movement over time (Fig. 3.10). We suggest the modern rates can only have been active for the last $\sim 50,000$ years, or less, based on elevation differences in the Kawerau area of the upper surface of Matahina ignimbrite (Milicich et al., 2013a). The onset of this modern tectonic regime could also be considered to partly reflect linked changes in eruption styles at Okataina from open vent activity dominated by fall deposits (terminating at $\sim 29 \mathrm{ka}$; Jurado-Chichay and Walker, 2000) to fissure fed, multiple vent complex and prolonged eruptions dominated by effusive activity starting at around $25 \mathrm{ka}$ (Nairn, 2002), marking initiation of young 'modern' TVZ rifting. 

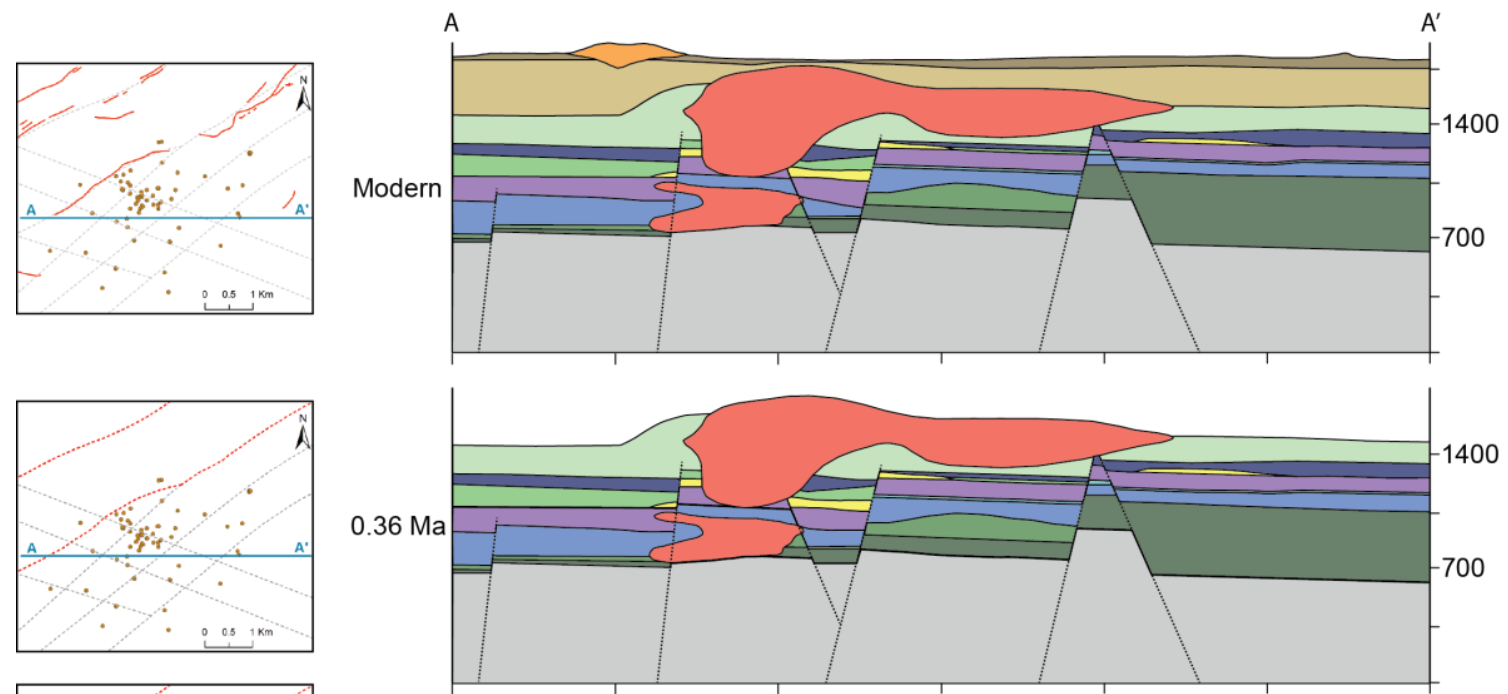

1400
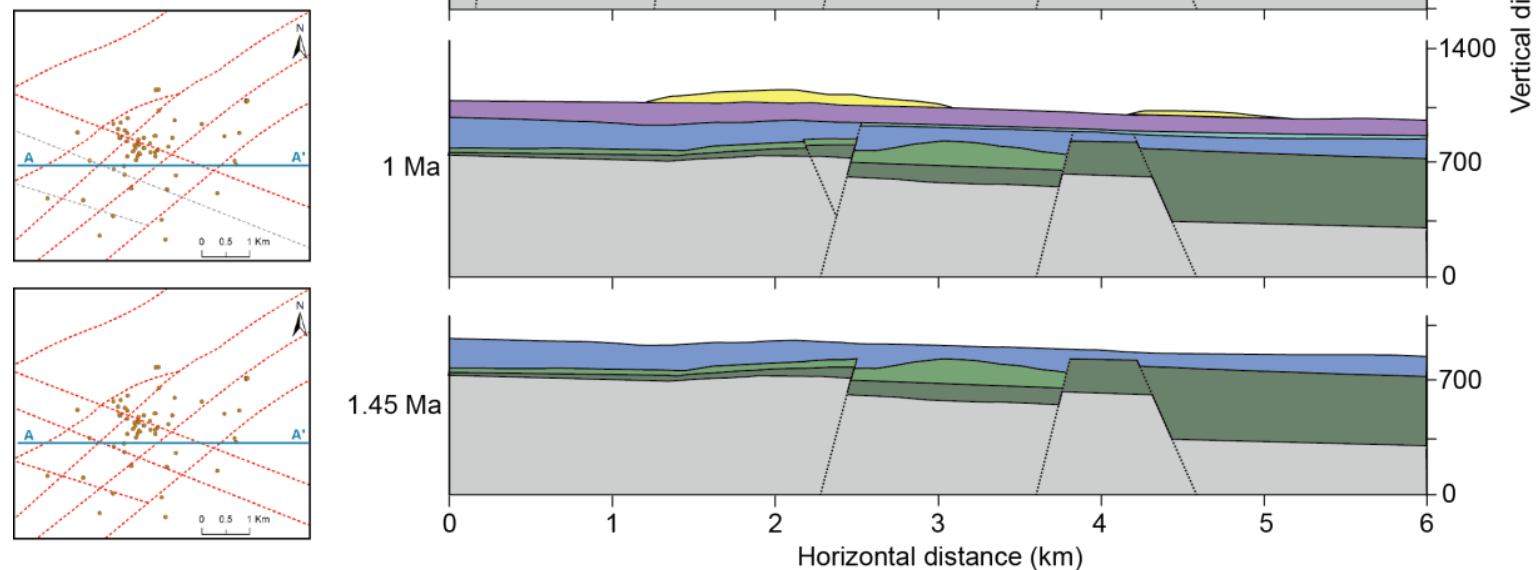

\begin{tabular}{|c|c|c|c|}
\hline \multicolumn{4}{|l|}{ Key: } \\
\hline & Surficial deposits & Onerahi Formation & Onepu Formation \\
\hline & Matahina ignimbrite & Kawerau Andesite & Rotoroa Formation \\
\hline & Caxton Formation & Raepahu Formation & Waikora Formation \\
\hline & Tahuna Formation & Tasman Formation & Mesozoic greywacke \\
\hline & Karaponga Formation & Te Teko Formation & Inferred fault \\
\hline
\end{tabular}

Figure 3.9 Cross sections showing the development of faulting in the Kawerau geothermal system over time. In the small fault maps on the left, the faults in dashed red lines indicate faults that moved in that time period, while those in grey did not. Blue lines mark the cross section alignment. The faults in red reflect the modern active faults (GNS Science, 2013). The movement indicates a general trend towards fewer active faults over time, with the influence of the NW-SE faults decreasing towards the modern situation and the NE-SW faults increasing their influence. The zero on the cross sections is arbitrary datum, with no geological significance. 

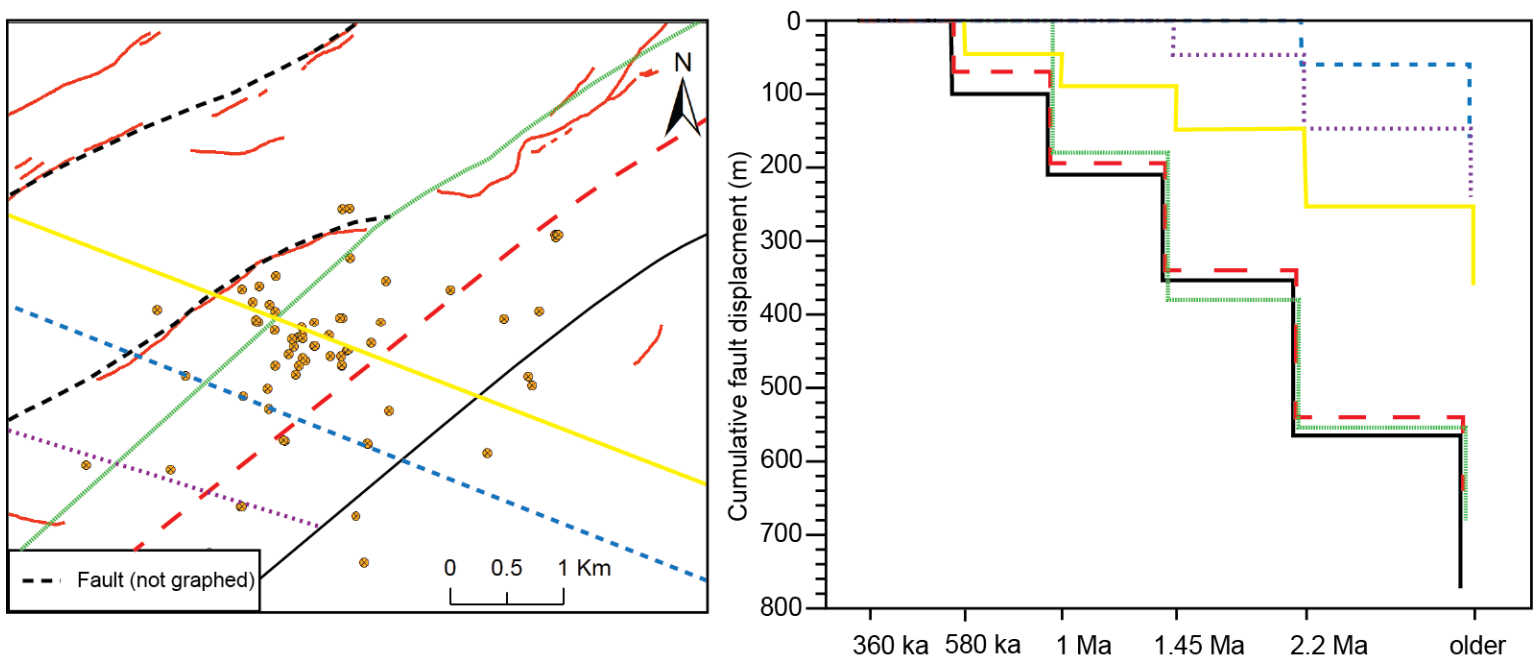

Figure 3.10 Approximate cumulative fault displacements determined from the offset in the tops of the units at this time period. The faults in red (left) are the modern active faults (GNS Science, 2013).

\subsubsection{Challenges in recognition of rock types in hydrothermal altered environments}

Distinguishing rock types in strongly altered hydrothermal environments can be extremely challenging. Commonly, despite intense hydrothermal alteration, the primary rock-forming mineral assemblage can be inferred, as replacement minerals occur as pseudomorphs filling the original crystal structure, although in many cases the primary volcanic textures are obliterated. For example, consider a silicic rhyolite lava and a silicic ignimbrite, both with the same mineral assemblage and intensely altered with the groundmass recrystallised to hydrothermal quartz. In such cases, the primary volcanic textures are usually destroyed and the rocks look remarkably similar in hand specimen. This is particularly true in crystal poor units, where there are few phenocrysts to aid with the correlation (e.g., compare Fig. 3.7A with Fig. 3.5H). Not until thin section examination, combined with age data, was applied could these materials be distinguished.

This study has successfully clarified the stratigraphy at Kawerau through a combined approach of $\mathrm{U}-\mathrm{Pb}$ zircon age dating, new hand specimen description and petrography, and revision of stratigraphic relationships, in a situation where individually applied techniques have previously proved ambiguous. Careful logging of core and drill cuttings needs to be combined with frequent thin sections, increased frequency of coring, appreciation of the limitations of drill cuttings and, where possible, age data to confirm correlations. Assumptions such as similarity in appearance and mineralogy, or similar stratigraphic level in the field need to be avoided, as they can be misleading. For example, ignimbrites shown in Fig. 3.7B and Fig. 3.7C are at similar stratigraphic levels in nearby wells, and are superficially similar with respect to their 
lithic components and primary quartz, plagioclase and biotite. Age data, however, shows that these are from different formations, with a $\sim 0.5 \mathrm{Myr}$ difference in age.

This approach also proved successful in distinguishing intrusive from extrusive units. The coherent rhyolite of the Caxton Formation had been previously attributed (Browne, 1978a) to multiple extrusive lava flows on the basis of flow banding (Fig. 3.5F, G) and/or brecciation. Age dating demonstrated that these multiple units were of similar age, and implied that intrusive rhyolite can indeed have flow banding (cf. Tian and Shan, 2011). This provides a cautionary tale when describing coherent rhyolite in the hydrothermally altered geothermal environment not to use flow banding to label a rock as extrusive without other evidence.

\subsubsection{Significance of greywacke}

The basement greywacke at Kawerau hosts major faults and fractures zones that feed hightemperature fluids into the Quaternary volcano-sedimentary cover succession. The fact that the main producing reservoir at Kawerau is hosted in the greywacke is currently unique in the TVZ setting (Wood et al., 2001), as most of the TVZ geothermal fields produce from the Quaternary volcano-sedimentary sequences. Wood et al. (2001) proposed that the 'andesitedacite' derived greywackes found at Kawerau may sustain brittle fracture at higher temperatures and greater depths than the more ductile 'granite-rhyolite' derived Torlesse greywackes at other geothermal systems where greywacke is intersected, such as Ohaaki. The ability of the greywackes at Kawerau to accommodate initiation and growth of fracture would explain why the basement at Kawerau has more fault-related permeability than that found at Ohaaki.

It is plausible that the boundary between the Waipapa and Torlesse composite terranes lies close to or under the Kawerau Field (cf. Leonard et al., 2010), and the hydrothermal fluids and magmas are utilising this major suture (running northeast-southwest) to move through the basement. Movement along these northeast-southwest structures would allow reactivation and rupture of the more minor cross-cutting northwest-southeast faults and sustaining of permeability pathways in the northwest direction.

\section{$3.4 \quad$ CONCLUSIONS}

$\mathrm{U}-\mathrm{Pb}$ dating of zircons, in combination with detailed petrographic correlations, have been used to redefine the stratigraphic sequence at the Kawerau Geothermal Field. This new understanding of the stratigraphy has allowed us to reconstruct the geological history of the 
area encompassed by the modern system, including the focussing of heat associated with local magmatism, and the faulting and subsidence histories which we relate to shifting patterns of regional tectonic activity.

1. Our age determinations (Milicich et al., 2013a) show that the modern geothermal system is very young, and is superimposed on an area that has experienced previous magmatic activity directly (evidenced by coherent lavas and intrusive rocks encountered by drilling within the geothermal field). There is evidence for at least four periods when magma was present beneath the Kawerau area, and produced a number of extrusive and intrusive igneous deposits/intrusions. The youngest of these is the Putauaki volcanic system, whose youthful age and composite construction of its volcanic ediface strongly point to the presence of an active magma reservoir or hot pluton that provides thermal support for the modern field. The surficial extrusion or lavas, and presence of feeder dikes of the Onepu Formation at $0.138 \mathrm{Ma}$ are inferred to represent a discrete magmatic event, but may not have been accompanied by a large thermal pulse in the near-surface. Between at least 0.43 and $0.36 \mathrm{Ma}$ there is evidence of a sustained local magmatic source feeding the rhyolite lavas and intrusions of the Caxton Formation, and slightly older pyroclastic rocks of the Tahuna Formation. A further period of magmatism is indicated by the presence in the Caxton and Onepu formations and associated tuffs with persistent tails of zircon ages in the $0.55 \pm 0.05 \mathrm{Ma}$ range. The Kawerau Andesite provides the oldest evidence of magmatic activity beneath the modern Kawerau Field, and has an age of 0.60 to $1.0 \mathrm{Ma}$, based on ages of bracketing silicic volcanic units. It is unlikely that magma feeding the Kawerau Andesite fuelled a geothermal system. Of these episodes of local magmatism, only that associated with the Holocene Putauaki and the $0.43-0.36 \mathrm{Ma}$ Tahuna/Caxton systems have left clear thermal influence on the field. In between these episodes we suggest the area was hydrothermally quiescent, and that the current Kawerau geothermal system is young, and possibly little more than $\sim 16$ $\mathrm{ka}$ (coincident with dated hydrothermal eruption deposits in the area).

2. Much of the primary rhyolitic material is derived from distal sources, and act as marker planes that can be used to infer faulting rates and structural development across the field. Deposition of ignimbrite within the Kawerau area was episodic, reflecting bursts of eruptive activity from outside the Kawerau area at $1.45-1.35 \mathrm{Ma}$ (Te Teko Formation), $1.0 \mathrm{Ma}$ (Raepahu Formation) and 0.5 - 0.6 Ma (Karaponga Formation). No pyroclastic deposits were present to sample in the time periods between these, despite widespread ignimbrites being erupted in the TVZ in these time intervals (not deposited, eroded, topographical controls). 
3. Many of the sediment-dominated intervals in the Kawerau Geothermal Field were previously allocated to the Huka Falls Formation (HFF). Where first defined at Wairakei (Grindley, 1965) the formation post-dates the buried Whakamaru group ignimbrites and so cannot be the time equivalent of any of the sedimentary packages we define at Kawerau, as these are shown to be older. Grindley (1965) correlated his HFF with marine and terrestrial sediments at Matata on the Bay of Plenty coastline which are now known to incorporate tephras equivalent in age to the Karaponga Formation at Kawerau (Hikuroa et al., 2006; Milicich et al., 2013a). Similarly, intervals of ignimbrite previously petrographically correlated as Rangitaiki ignimbrite have been shown to be much older, and have now been dated at 0.6, 1.0 and 1.46 Ma.

4. The early sediments at Kawerau are dominated by greywacke gravels of the Waikora Formation which infill strike-slip generated half-grabens. Any topographic relief generated at this time was subdued by the time a regionally distributed ignimbrite was deposited over the field at $1.46 \pm 0.01 \mathrm{Ma}$.

5. The successive magmatic events beneath the Kawerau Field have supplied heat to fluids that likely utilised similar permeability pathways and rejuvenated the geothermal system. Though the cooling of a magmatic event would result in cooling of the fluids and likely promote silica self-sealing, re-activation of faults, independent of any heat input, could maintain or enhance fluid pathways. The state of the system between these episodes of local magmatic heat flux has not been determined.

6. The age data and associated stratigraphic correlations show that post-1.5 Ma normal faulting has accompanied episodic tectonic subsidence of the Kawerau area, with fault movement focussed on northeast-southwest structures (associated with the geometry of the modern TVZ) and reactivation of northwest-southeast structures that experienced the greatest displacement prior to $1.5 \mathrm{Ma}$. The contrast between emplacement of coherent rhyolite as sills at $0.36 \mathrm{Ma}$ and a dike at $0.138 \mathrm{Ma}$ reflect a shift in orientation of the principal stress axes, in response to initiation of the modern TVZ rifting regime.

7. This paper shows the importance of consistency in description in overcoming problems in cross-correlation. In geothermal development, where it is inevitable several geologists may be required to describe and log drillcuttings and core, that periodic re-evaluation and review of the correlations is essential. A robust dating programme feeding into stratigraphy and structural studies being used to infer system development can be invaluable, and will provide confidence in the stratigraphic interpretations, help clarify 
controls on permeability and reduce risk for subsequent well targeting and drilling operations.

\subsection{ACKNOWLEDGEMENTS}

We acknowledge funding support for this project from Mighty River Power Ltd and their permission, along with that of Ngati Tuwharetoa Geothermal Assets Ltd, to publish these data. Thanks also go to A8D Trust, Putauaki Trust, Te Tahuna Putakuaki Trust and other local Maori trusts for access to well core and cuttings. Additional funding came from a Victoria University $\mathrm{PhD}$ scholarship to SDM and for CJNW from the FRST Programme "Deep Geothermal Resources" through subcontracts from The University of Auckland, by courtesy of Mike O'Sullivan. Thanks also to Patrick Browne and Michael Rosenberg for valuable comments and discussion on the early work at Kawerau. Thanks to two anonymous reviewers for their valuable comments and Prof. Lionel Wilson for editorial handling. 
Chapter 3 


\title{
CHAPTER 4
}

\section{3-D INTERPRETATIVE MODELLING APPLIED TO THE GEOLOGY OF THE KAWERAU GEOTHERMAL SYSTEM, TAUPO VOLCANIC ZONE, NEW ZEALAND}

\author{
Sarah D. Milicich, Candice Bardsley, Greg Bignall, Colin J.N. Wilson
}

Paper submitted with Geothermics

Statement of authorship: CB assisted SDM with 3-D modelling and associated discussions.

All authors assisted SDM with editing of the manuscript. 


\section{ABSTRACT}

Successful development of a geothermal system requires reliable information on its permeability and fluid pathways, which can be fault-controlled and/or influenced by the lateral extent of its reservoir rocks. Utilisation of implicit 3-D visualisation and modelling software allows complex geological and structural framework models to be established that support exploration, and help constrain borehole-targeting with reduced drilling risk and cost. The ability to model geology in a 3-D interface has provided new insights regarding the geological framework, controls on deep-seated permeability, volcanic and basement stratigraphic correlations, and geothermal system evolution in a case study from Kawerau, New Zealand.

\subsection{INTRODUCTION}

In geothermal exploration and development, translating geological information from surface geology and borehole records into formats that enable reservoir engineers and field managers to operate the field for maximum efficiency is often a challenge. In particular, geologists have traditionally utilised two-dimensional (2-D) maps and cross sections to infer the relative age and stratigraphic/structural relationships of rock units, as well as the locations of fault structures. These data are central to understanding the permeability characteristics of the system and its likely response to utilisation. Geological units and structures are threedimensional (3-D) in space, however, so accommodating the dimensionality of geological data was severely constrained prior to development of 3-D visualisation software. 3-D visualisation tools can inform in different ways scientists, reservoir engineers, field managers, decision makers for resource allocation (by the New Zealand resource consent process), or the general public. Many of these people may not have an appreciation of geological principles, to image, model and interpret geological data and understand the framework structure of a geothermal system. Instead of relying on maps and cross sections to display the geological data in 2-D, 3-D visualisation can assist geologists to resolve the geospatial relationships of geological bodies which can then be integrated into field management models and strategies. The main value of 3-D visualisation is it overcomes the distortion of spatial relationships that limit conventional 2-D representations. An additional advantage is that the inclusion of digital data (e.g. seismic cross sections, LIDAR, GPR or SAR imagery) is straightforward, which allows visualisation of these data sets in 3-D in conjunction with the geological information. In this paper, we apply 3-D modelling and visualisation techniques to a newly derived suite of geological information in a case study of the Kawerau geothermal system in New Zealand. 
The work reported here has been carried out as a collaborative project between GNS Science and Mighty River Power Ltd., operators of a 100 MWe geothermal power station in the Kawerau Geothermal Field.

\subsection{SETTING OF THE KAWERAU GEOTHERMAL SYSTEM}

Kawerau is the northernmost of 23 currently active high-temperature geothermal systems in the central Taupo Volcanic Zone (TVZ) of New Zealand (Fig. 4.1; Bibby et al., 1995; Rowland and Sibson, 2004; Kissling and Weir, 2005; Rowland and Simmons, 2012). The TVZ is a rifted arc that is segmented into three parts (Healy, 1962; Wilson et al., 1995a), the central one of which is dominated by rhyolitic caldera-related volcanism and contains numerous high-temperature geothermal systems. In contrast, the northern and southern segments are dominated by andesite-dacite composite-cone volcanism with sparsely distributed geothermal systems (Bibby et al., 1995; Wilson et al., 1995a; Fig. 4.1). The Kawerau geothermal system is sited at the transition between the sources of voluminous silicic volcanism and associated magmatism to the southwest and the andesite-dacite northern TVZ arc segment to the northeast (Nairn, 2002; Fig. 4.1). Structurally, the Kawerau system lies within the southern part of the northeast-striking Whakatane Graben (Fig. 4.1), in a zone where the active TVZ rift structures intersect the north-striking strike-slip faults of the North Island Shear Belt (Nairn and Beanland, 1989; Mouslopoulou et al., 2007; Begg and Mouslopoulou, 2010; Villamor et al., 2011).

The Whakatane Graben is infilled in the Kawerau area to a thickness of at least $1 \mathrm{~km}$ with Quaternary sediments, together with Quaternary volcanic rocks from TVZ sources and Miocene-to early Pleistocene volcanic rocks derived from the Coromandel-Kaimai area to the northwest (Booden et al., 2012; Milicich et al., 2013a). The volcanic/sedimentary succession overlies a basement of indurated metasediments ('greywacke', Fig. 4.1) of Triassic to Cretaceous age (Wood et al., 2001; Mortimer, 2004; Leonard et al., 2010), within which fault structures provide major conduits for high-temperature geothermal fluids. The oldest surface rocks in the Kawerau area are the regionally extensive $322 \mathrm{ka}$ Matahina ignimbrite and pre$322 \mathrm{ka}$ rhyolite lavas which crop out west and northwest of the field, and are extensively faulted and uplifted to form the western shoulder of the Whakatane Graben. 


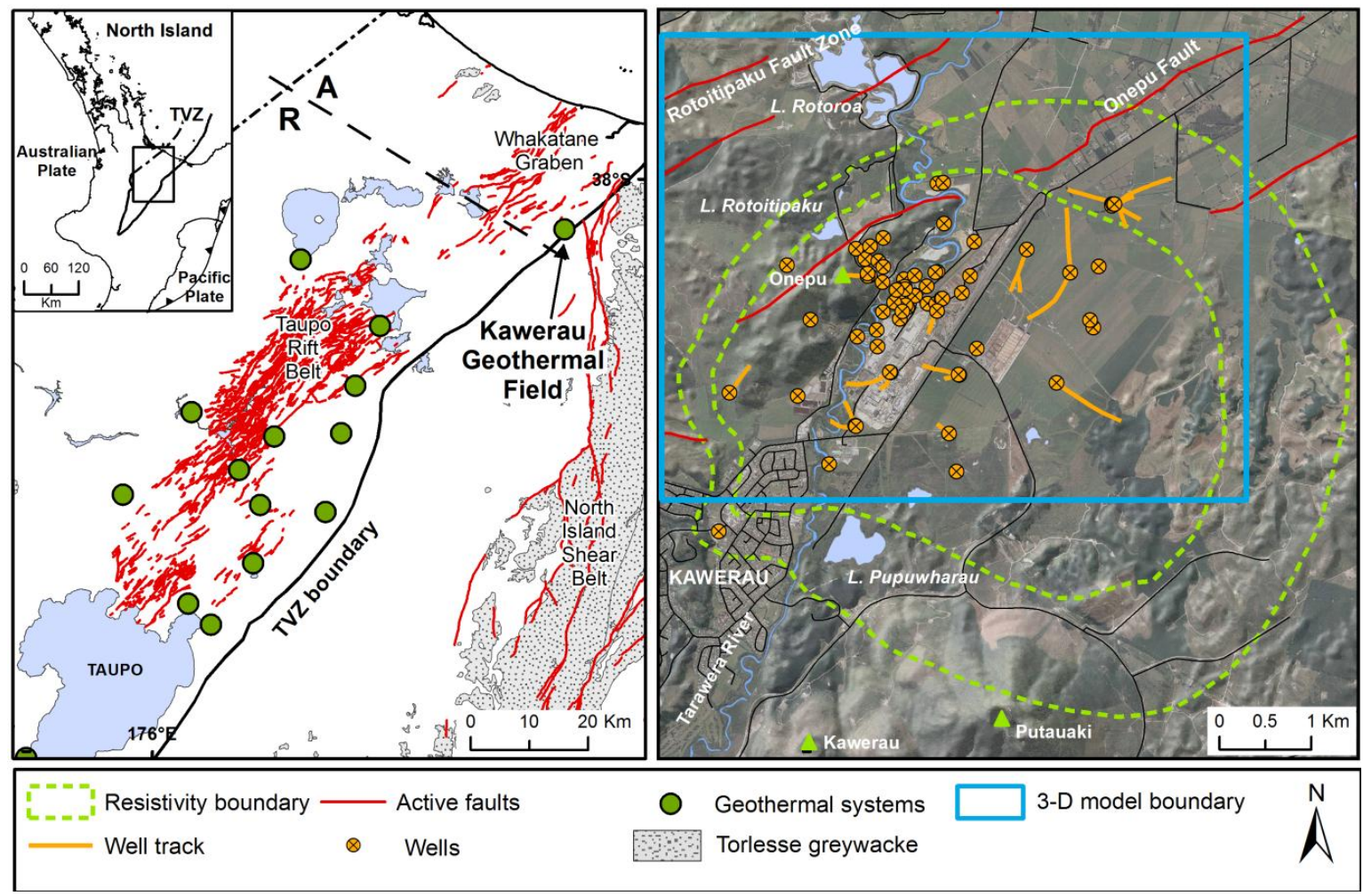

Figure 4.1 Left: location of TVZ high-temperature $\left(>200{ }^{\circ} \mathrm{C}\right)$ geothermal systems defined by geophysics and/or drilling (green circles). Outcrops of the greywacke basement are highlighted in grey and active faults are in red (GNS active faults database: GNS Science, 2013). The boundary of the TVZ is shown, with its subdivisions into andesite-dominated (A) north and the rhyolite dominated (R) central segment. Right: Kawerau Geothermal Field, with approximate resistivity boundary zone at about $500 \mathrm{~m}$ depth (after Allis et al., 1995) and location of wells. Active faults are in red (from Leonard et al., 2010).

Within the Kawerau Geothermal Field, more than 70 boreholes (Fig. 4.1) have been drilled for fluid utilisation, reinjection or monitoring. The stratigraphy encountered by drilling at Kawerau had previously been described and defined by Nairn (1977, 1981, 1982, 1986), Grindley (1986), Christenson (1987) and Allis et al. (1995). Overall summaries of this work were presented in Bignall and Harvey (2005) and Milicich et al. (2010a), but the stratigraphic correlations were inconsistent and ages of most rock units unknown. The development of the 3-D visualisation stratigraphic and structural framework model discussed here is an integral part of a wider project which involved a complete revision and redefinition of the stratigraphic framework of the Kawerau geothermal system, utilising an extensive suite of zircon $\mathrm{U}-\mathrm{Pb}$ age data (Milicich et al., 2013 a,b).

\subsection{MODELLING THE KAWERAU GEOTHERMAL SYSTEM}

The geological data in this paper has been visualised using Leapfrog Geothermal, a 3-D modelling and visualisation software package developed by ARANZ Geo Ltd. specifically for the geothermal industry (ARANZ Geo Ltd., 2013). This software is used by the New Zealand geothermal community (e.g. at Ohaaki and Wairakei geothermal fields, as well as over larger 
areas of the central TVZ) and worldwide to create models of geothermal systems (e.g. Milicich et al., 2010b; Sepulveda et al., 2010; Alcaraz et al., 2010, 2011; Massiot et al., 2011).

Geological framework models of the Kawerau geothermal system were built to test the validity of independent interpretations, in this case using two different 3-D modelling software platforms. These were built in Leapfrog Geothermal for this study, and in the MVS software platform (CTECH, 2013), the latter in-house by Mighty River Power Ltd. (Bardsley, 2010). Both models utilised the same basic framework for the fault network and orientation, which took account of past interpretations (Wood et al., 2001) and insights from recent drilling (unpublished confidential GNS Science and Mighty River Power Ltd borehole geology well reports). The two models were subsequently compared to each other in order to evaluate the alternative interpretations and resolve ambiguities that had arisen. This process was repeated, until the models agreed with each other. In this manner systematic errors and misinterpretation were more easily and quickly identified.

The Leapfrog Geothermal model currently incorporates data from 95 geothermal boreholes and shallow boreholes used for monitoring. The locations and survey data for the boreholes were provided courtesy of Mighty River Power Ltd. Geology datasets were obtained during relogging of cores and cuttings from boreholes owned by numerous parties (primarily Mighty River Power Ltd. and Ngati Tuwharetoa Geothermal Assets Ltd.) and have been reported in Milicich (2013b) [Electronic Appendix 1] and Milicich et al. (2013b) [Chapter 3].

\subsection{WORKFLOW METHODS}

The following bullet points detail the process stream with which we built the Kawerau geothermal system 3-D geological framework model.

1. Definition of the region of interest. We have focused on a localised area of the Kawerau geothermal system that encloses the geothermal boreholes (that is, the Kawerau Geothermal Field which is the man-made entity). The geographical location of the model is northeast of the township of Kawerau, with an extent of 5.8 by $3.9 \mathrm{~km}$ (Fig. 4.1). The model is constrained vertically by the topography (defined by a Digital Terrain Model of New Zealand from GNS Science).

2. Importing data. Along with the recently updated geothermal borehole stratigraphy data (Milicich, 2013b [Electronic Appendix 1]; Milicich et al., 2013a) we imported GIS datasets, such as fault locations from Leonard et al. (2010), lakes, rivers and roads (Land 
Information New Zealand data sets; http://www.linz.govt.nz/topography/topographicdata) and surface outcrop areas of geological units shown in the 1:250,000 QMAP geological map of Rotorua (Leonard et al., 2010). These are the data sets used in the following model building process.

3. Building the structural network. The geometry of faults uses that of Rotorua QMAP faults (Leonard et al., 2010) where they are present. As most of the faults used in the model have no surface expression, a uniform dip of 80 degrees to the northwest was applied, which is consistent with elsewhere in the TVZ (Villamor and Berryman, 2001). Hierarchies and relationships between faults were designed to create a geologically consistent and realistic structural framework.

4. Building the geology surfaces. In creating a geological surface, the modelling is pinned to stratigraphic contact points from the borehole data loaded in the software. This means that all boreholes with that contact point are used to generate the surfaces, i.e., if a unit is intersected in the borehole, then it provides a factual depth to locally constrain the surface of that unit. If a unit does not intersect that borehole, then the surface is automatically forced underneath the borehole maximum depth, meaning that it will not be included in generation of that surface. Some surfaces were also constrained using surficial outcrops from the Rotorua QMAP geological map (Leonard et al., 2010). The building of the structural network and stratigraphy is an interlinked process. Typically an unfaulted stratigraphic sequence is first built from bottom up, and obvious offsets in this sequence used to inform the structural network. Following this, the structural network is applied to the stratigraphic sequence and the full faulted model is built.

5. Adjusting surfaces. In an area with no boreholes the surfaces were manually edited, constrained by an understanding of geological morphology. In addition, in some places where manual over-ride was considered necessary, user-defined trends and edits were applied such that geological units and their spatial relationships were best fitted for the model (e.g. morphology of coherent rhyolite units). These manual edits are tracked, meaning that when future drilling occurs in the area of interest, the manual edits can be discarded and replaced with the factual information from the borehole. Anisotropy and manual edits can also be applied to lavas and intrusive bodies to give them geologically more realistic shapes. 


\subsection{KAWERAU GEOTHERMAL SYSTEM 3-D MODEL}

\subsubsection{Structure}

The location of faults is inferred by offsets in the stratigraphy from the borehole data from the bottom up, starting with the greywacke basement where the displacements are more clearly defined (usually because faulting offsets increase with depth). These faults, used to build the structural framework, are presented in Video 1 (Electronic Appendix 5). To provide a realistic fault network for the model, only faults evident in offsets in the stratigraphy above the basement were included. It is thus possible the structure is more complex than represented. It is likely also that, rather than being represented by single 'major' faults, offsets are actually defined by 'damage zones' or intervals where there are multiple splays. However, these are difficult to identify in boreholes, and typically only faults with offsets in the geology of $>20 \mathrm{~m}$ can be confirmed.

Many of the faults in the Kawerau area have no surface expression, either due to burial by recent pyroclastic deposits or volcaniclastic alluvial sedimentation in the Tarawera River flood plain, or because the faults only offset deeper units in the stratigraphy (i.e. they are fossil structures). The orientation of the faults is tightly constrained by the dense cluster of boreholes in the geothermal field (Fig. 4.1). The faults with the largest apparent offsets are aligned with the northeast-southwest grain of the modern TVZ rift system and are the dominant fault structures in the model. Several of these faults are classed as active (i.e., ruptured in the last 20,000 years: GNS Science, 2013). These include lineaments of the Onepu fault and Rotoitipaku fault zone (Fig. 4.1), the latter of which ruptured at the time of the 1987 Edgecumbe earthquake (Nairn and Beanland, 1989). Apart from the Onepu fault and Rotoitipaku fault zone, other faults of this orientation only affect units deeper than the $\sim 440$ Ma Tahuna Formation (Milicich et al., 2013a; Table 4.1). A second set of faults run roughly northwest-southeast and primarily show displacement across the deeper units $(>1 \mathrm{Ma})$ in the system. The full implications and timing of the faulting and structure in the Kawerau geothermal system are discussed in Milicich et al. (2013b). Video 1 (Electronic Appendix 5) shows the fault network used in creating the 3-D geological model of the Kawerau geothermal system. 
Table 4.1 Summary of the main stratigraphic units and lithologies in the Kawerau Geothermal Field (ages from Milicich et al., 2013a).

\begin{tabular}{|c|c|c|c|}
\hline Formation & Lithology & $\begin{array}{l}\text { Thickness } \\
\text { (m) }\end{array}$ & $\begin{array}{l}\text { Age* } \\
\text { (Ma) }\end{array}$ \\
\hline Recent Alluvium & $\begin{array}{l}\text { Peat deposits; sands and gravels; unconsolidated pyroclastics (incl. Whakamana Breccia, } \\
\text { Rotoiti Breccia) }\end{array}$ & $10-50$ & \\
\hline $\begin{array}{l}\text { Hydrothermal Eruption } \\
\text { Breccias }\end{array}$ & Hydrothermal eruption deposits, from $\sim 16,000$ and $\sim 9,000$ yr BP & $1-10$ & \\
\hline Unconsolidated pyroclastics & Unwelded pumiceous pyroclastic flows and airfall tuffs & $0-80$ & \\
\hline Onepu Formation & $\begin{array}{l}\text { Twin surficial domes of rhyodacite (pl, qz, px, hb, bt) and intrusive (porphyritic crystal- } \\
\text { rich; corroded } \mathrm{qz}, \mathrm{pl} \text {, mafics) }\end{array}$ & $2-200$ & 0.15 \\
\hline Matahina ignimbrite & Partly welded grey-brown ignimbrite \& vitric tuff (pl, qz, px) & $10-410$ & $0.32 * *$ \\
\hline Tahuna Formation & $\begin{array}{l}\text { Crystal-rich, fine sandstone, siltstone, muddy lithic-breccia and unwelded pumice- } \\
\text { rhyolite lapilli tuff }\end{array}$ & $0-360$ & 0.44 \\
\hline Caxton Formation & $\begin{array}{l}\text { Buried domes of spherulitic and banded rhyolite (corroded and fractured qtz and } \mathrm{pl} \text { ) } \\
\text { and intrusive (corroded and fractured } \mathrm{qtz} \text { and } \mathrm{pl}, \pm \mathrm{bt} \pm \mathrm{amp} \text { ) }\end{array}$ & $0-450$ & 0.36 \\
\hline Karaponga Formation & Partly welded crystal-lithic tuffs (pl, qz \pm bt) & $0-180$ & $0.51-0.60$ \\
\hline Onerahi Formation & Tuffaceous to muddy breccias and coarse tuffaceous sandstone & $0-85$ & \\
\hline Kawerau Andesite & Augite-plagioclase andesite flows, breccias and tuff (in south) & $0-300$ & \\
\hline Raepahu Formation & $\begin{array}{l}\text { Partly welded crystal-vitric tuffs (qz,pl,bt, lithic-poor and qz,pl,bt, ferromagnesians, } \\
\text { lithic-rich) }\end{array}$ & $0-165$ & 1 \\
\hline Tasman Formation & $\begin{array}{l}\text { Muddy breccia, sandstone and siltstone, but widely represented by reddish brown } \\
\text { siltstone }\end{array}$ & $0-25$ & \\
\hline Te Teko Formation & Partly welded grey crystal-vitric tuff (corroded qz, pl, bt) & $0-255$ & $1.34-1.46$ \\
\hline Rotoroa Formation & Tuffaceous sandstone, poorly sorted crystal and vitric, water-laid tuff, siltstone & $0-200$ & $2.17-2.4$ \\
\hline Waikora Formation & Greywacke pebble conglomerate and minor intercalated tuff and siltstone & $0-450$ & \\
\hline Greywacke basement & Weathered, sheared greywacke and argillite & - & \\
\hline
\end{tabular}

Abbreviations used are $\mathrm{pl}=$ plagioclase $\mathrm{qz}=$ quartz $; \mathrm{px}=$ pyroxene; $\mathrm{hbl}=$ hornblende; $\mathrm{bt}=$ biotite; amp $=$ amphibole. Ages from $*$ Milicich et al. (2013a) and **Leonard et al. (2010). For the purposes of the model, recent alluvium, hydrothermal eruption breccias and unconsolidated pyroclastics are grouped together as 'surficial deposits'. 


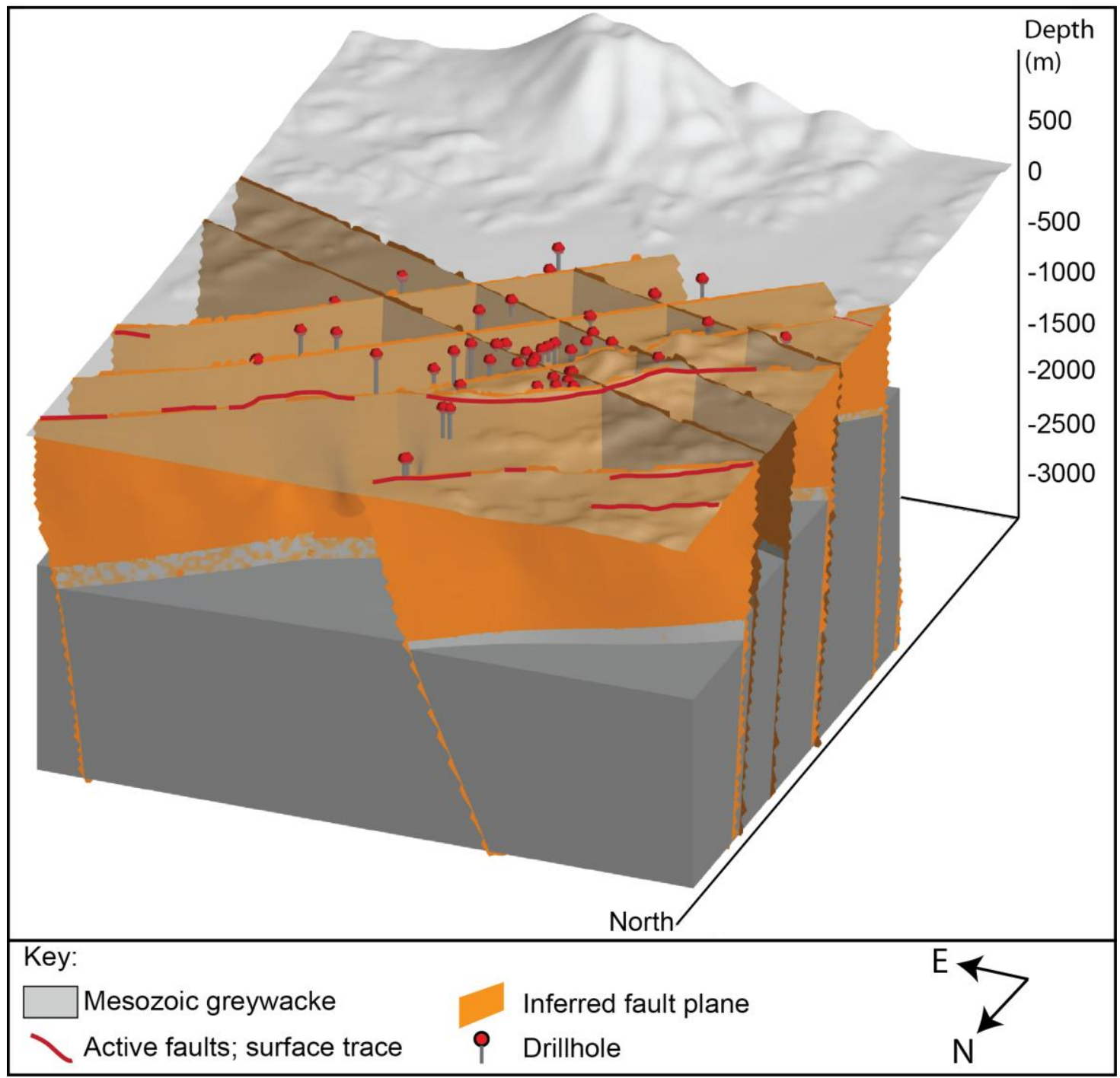

Video Still 1 (Electronic Appendix 5) Structural network of inferred faults used in the construction of the 3-D geology model of the Kawerau geothermal system. Red lines on the surface are faults from the Rotorua QMAP (Leonard et al., 2010). The key applies to the video file.

\subsubsection{Geology}

The geology (Table 4.1) represented in this 3-D visualisation model (Video 2; Electronic Appendix 6) is described in detail in Milicich et al. (2013a,b). The volcanic succession ( $\sim 800$ to $1200 \mathrm{~m}$ thickness) in the field rests on Mesozoic volcaniclastic sandstone (greywacke) and siltstone (argillite) of broadly intermediate composition. There is ambiguity in the categorisation of the Kawerau greywacke. Wood et al. (2001) classified the greywacke at Kawerau as belonging to the Waioeka (petro-) facies of the Pahau terrane (i.e., part of the Torlesse composite terrane; Leonard et al., 2010). In contrast, on the same lithological basis, Adams et al. (2009) assigned the greywacke to the Waipapa composite terrane, and linked it to greywacke exposed at the ground surface $\sim 30 \mathrm{~km}$ to the northwest of Kawerau. 


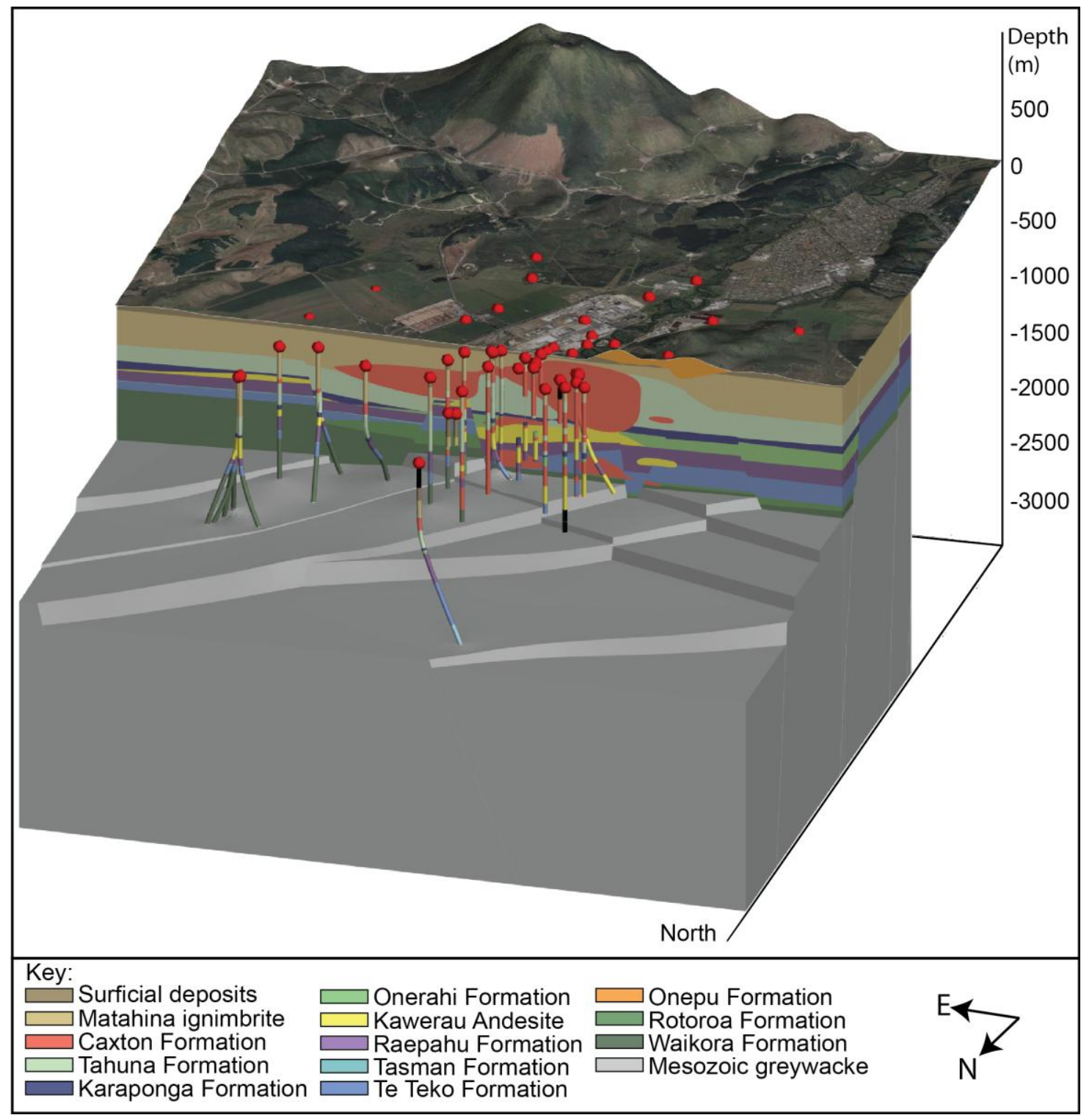

Video Still 2 (Electronic Appendix 6) 3-D geological visualisation of the Kawerau geothermal system. The key applies to the video file.

In the Kawerau area, the greywacke basement has been cut by strike-slip faults with the generation of pull-apart basins prior to $1.5 \mathrm{Ma}$. These basins were infilled by greywacke gravels with minor intercalated tuffs and fine-grained sediments of the Waikora and Rotoroa formations, with two intercalated ignimbrites dated at $2.38 \pm 0.05 \mathrm{Ma}$ and $2.17 \pm 0.05 \mathrm{Ma}$ (these and other age determinations cited in this paper are from $\mathrm{U}-\mathrm{Pb}$ age determinations on zircon; Milicich et al., 2013a). Thick ignimbrite groups mapped across much of the entire field are clustered in time, with bursts of activity forming the Te Teko Formation $(1.45-1.35 \mathrm{Ma})$, Raepahu Formation ( 1.0 Ma) and Karaponga Formation (0.5 - 0.6 Ma). These ignimbrite groups are commonly separated by intervals of volcaniclastic and sedimentary accumulations (with associated palaeosol development) which may represent long time periods, but are not particularly thick (e.g. sediments mapped as the Tasman Formation are $<20 \mathrm{~m}$ thick yet represent a $\sim 550 \mathrm{kyr}$ interval). These units, constrained by dating and petrography, provide 
marker horizons which can then be used to define apparent fault offsets. In particular the sub-horizontally emplaced ignimbrites are useful in this regard.

Numerous bodies of coherent material (as opposed to tuff), of rhyolite to rhyodacite composition were intersected at various levels in boreholes in the field (Grindley, 1986). These bodies can be shown from geochronology and petrography to represent a combination of dome intrusions and sills emplaced over restricted time periods, rather than domes extruded on many different occasions through the history of the field. The Caxton Formation rhyolites, with a best estimate for eruption/emplacement age of $0.36 \pm 0.03 \mathrm{Ma}$, are represented by crystal richer and crystal-poorer lithologies, each of which is represented by domes and sill intrusions. The $138 \pm 7 \mathrm{ka}$ Onepu Formation rhyodacite is represented by surficial domes and two dike intersections at depth. These rhyolite units are often permeable, and provide conduits for cool marginal meteoric water to potentially flow back into the field. Understanding their emplacement mechanism and hence geometry has improved their representation in the model. Their location and geometry, tied in with reservoir data, can then be used to inform decisions on drilling and reinjection strategy. Video 2 (Electronic Appendix 6) shows the 3-D visualisation model of the geology of the Kawerau geothermal system.

\subsection{DISCUSSION}

\subsubsection{An integrated approach to modelling and stratigraphic correlation}

The development of a 3-D visualisation of the geology and structure at Kawerau allows for the inferred controls on permeability to be put in context and to see how these fit with the conceptual model and can then be translated into the numerical model. The structural/stratigraphic controls on the reservoir rocks have direct implications in the development and management of the geothermal resource. The first step in this process required relogging cores and cuttings from the geothermal boreholes into a consistent stratigraphy (Milicich, 2013b; Electronic Appendix 1), and U-Pb dating of zircons from key stratigraphic horizons (Milicich et al, 2013a). Without the use of a reliable 3-D model, it would have been difficult to correlate stratigraphy using only traditional methods (i.e. 2-D cross sections).

The advantages of using the 3-D models lie in the flexibility of its use and application. For example, the operator can change viewing angles which is not possible in $2-\mathrm{D}$, or make instant calculations much quicker than when using 2-D models. The 3-D models permit the 
operator to have a concise representation of a unit, which allows for higher levels of consistency and accuracy, together with quicker rendering of changes and testing of hypotheses. It reduces the need for mental visualisations when making decisions on the correlation of stratigraphy, thus reducing risk of operator bias.

3-D modelling has allowed the basement structure inferred in the past (Wood et al., 2001) to be better defined. The major northeast-southwest striking faults are clearly expressed, with the basement downfaulted to the northwest (Video 1; Electronic Appendix 5). A northweststriking fault at Putauaki has been inferred to be a major pathway for fluid upflow in the vicinity of Putauaki volcano (Bignall and Harvey, 2005), with deep sourced, hot waters moving into the present borefield area via northwest-southeast striking faults that are intersected by northeast-southwest trending regional structural features. The expression of these faults can be traced back through the structural development of the system over the last $2.4 \mathrm{Ma}$ and visualised using the 3-D geological model of the field. The geological visualisation and $\mathrm{U}-\mathrm{Pb}$ dating of key marker horizons (generally sub-horizontally emplaced ignimbrites: Milicich et al., 2013a) across the field further aided in understanding the history of these faults. We can look at the timing of fault movement and hence maintenance/development of permeability pathways in the system (Milicich et al., 2013b).

The U-Pb geochronology and petrography showed rhyolite beneath the field represented dome extrusions and intrusions, rather than individual flows and domes (Milicich et al., 2013a). By visualising this rhyolite in 3-D we were able to reinterpret the emplacement of the intrusive bodies. The intrusions related to the Caxton Formation were emplaced horizontally (and extensively) as sills, and those related to the Onepu Formation were localised and emplaced vertically as dikes. The contrasts between these two emplacement mechanisms reflect a switching of the orientation of the principal stress axes accompanying development of the modern Whakatane Graben. Sill emplacement of the Caxton Formation rhyolites implies that $\sigma_{3}$ was vertical around $0.36 \mathrm{Ma}$, and thereafter switched to horizontal and was orientated northwest-southeast at the time of Onepu Formation rhyodacite dike(s) (Milicich et al., 2013b).

\subsubsection{Parallel model development}

The use of parallel models (Leapfrog Geothermal in this study [ARANZ Geo Ltd., 2013]; MVS software platform [CTECH, 2013] by Mighty River Power Ltd.) allowed for a more robust geological framework model to be developed, increased input from different sources 
(and in this case an industry standpoint) being fed into both models. The focus of this paper is not to compare these two (or any other) software platforms but to draw attention to the value, as a tool, of integrating methodology and expertise. Regardless of the modelling platform, there are some distinct advantages to be gained by following a process of independent model building and cross-evaluation. The major benefit that resulted was the identification of errors, both in operator input and model interpolation, some of which were not obvious until the separate models were compared side-by-side. The two-model build approach allowed multitesting of aspects of the model (e.g. lateral extent of rhyolite units), with the result being iterative change until a common framework model was built. Through the iterative process, the operators were able to adapt their models in order to adopt the most realistic interpretations of the geology and structure from each model. Such a framework model thus has the best elements of both models, while still being constrained by the data.

From an industry standpoint, there were significant advantages that arose from this twomodel approach. As knowledge transfer to the field operator (in this case Mighty River Power Ltd.) was required, this process ensured that the end product was designed to fit within and guide industry workflows (i.e. well-targeting rationales and associated considerations), as well as to interact with other key software/data sets not directly related to research. Industry standards are important in complex data systems such as 3-D models, and working on dual models allowed for these to be discussed and met as needed. For example, the building of the fault network, and the associated reasoning for the choice of fault positioning was a piece of Quality Assurance and Quality Control that the industry partner required visibility on. There was and always will be a need for transparency as to how and why things were built in any model, allowing the end product to be defendable if questioned, for example, in hearings for Resource Consents.

\subsubsection{Management tools from 3-D modelling}

While this paper only presents the geology (structure and stratigraphic framework) of the Kawerau geothermal system in 3-D, additional information can readily be added to the 3-D visualisations. This information could include interpreted (or measured) reservoir temperatures, hydrothermal alteration patterns, other structural information (fracture orientation and density) and geochemical data. In this manner, the geological model is able to be compared with occurrences (intensity, rank) of hydrothermal alteration, as well as numerically interpolated parameters, such as rock properties (e.g. porosity, density) and reservoir parameters (e.g. temperature, pressure) to aid in visualising interactions between the 
geology and field/reservoir parameters. The 3-D geology can also directly be imported into a numerical model of the system, allowing for consistency between the geology and the conceptual model of the field.

With appropriately integrated data sets, the model can be turned into a flexible boreholetargeting and reservoir management tool for visualising development strategies and monitoring the geothermal reservoir. Predictive borehole data and conditions can be interpolated from geological and numerical models. A 3-D visualisation of the geology (with or without other parameters) is thus a key tool for clearly expressing ideas and solutions to external parties, such as board members, executive teams and general public. The model can be used by industry to reduce drilling risk and hence enhance the viability of an exploration/development programme. The benefits of the 3-D model also include an enhanced workflow, with more reliable information conveyed quickly in a clear format. Without having to redraw new 2-D sections when decisions need to be made, the speed and efficiency of operation is increased. In particular, as changed geological constraints are shown up by new borehole information, the geology is readily modified for the whole field.

Permeability and fluid flow at Kawerau is recognised to be controlled primarily by faults and fractures (Bignall and Harvey, 2005), hence recognising the structural fabric has become important in field management. Faults directly influence the field developers in targeting the inferred structural fabric by drilling deviated wells, in order to give a better chance of encountering inflow of hot fluids from these structures. Reinjection strategies can also potentially be affected, as injected fluid is more likely to follow fracture pathways. This leads field managers to consider whether faults and the cross-cutting structural fabric could in future be implicated in return of fluids to the main production part of the field more quickly than if these structures had not been there.

The development of 3-D visualisation of the geology has also resulted in a greater resolution of near-surface volcanic rocks that can act as conduits for cool marginal fluids to move into the field. This is a feature common to other TVZ geothermal systems, where near-surface fractured lava and permeable pyroclastic rocks allow ingress of cool water into the system (Bromley et al., 1993; Newson and O’Sullivan, 2001; Bixley et al., 2009). Recognising the extent of these units and effectively modelling them is a factor in defining the reinjection and well targeting strategy. In this manor, the 3-D geological framework supports the effective adaptive management of the field. 


\subsection{CONCLUSIONS}

During the exploration and development of a geothermal resource it is crucial to have confidence in the delineation of the extent of reservoir rocks and permeable horizons. This knowledge optimises targeting of boreholes, which reduces risk and drilling costs, and allows for the most effective on-going management of the resource, once it is operating as an economic concern. General conclusions from this work are as follows:

- Complex geological and structural frameworks are often difficult to visualise in 2-D. The development of a 3-D visualisation model of the geology hosting the geothermal system is key to understanding complex data sets.

- The geological information (lithologies, ages, faulting) is the basic framework on which all other applications/activities are pursued. The integrated geological data can be used to interpret and understand patterns of reservoir temperatures, hydrothermal alteration, structural information (fracture orientation and density) and geochemistry.

- The ability to model the geological information in a 3-D interface has provided new insights regarding the geological and structural framework of the Kawerau area. It has impacted on our understanding of the controls on deep-seated permeability in the Kawerau geothermal system. This understanding has direct implications for the ongoing development and management of the geothermal resource, the Kawerau Geothermal Field.

- The ability of the 3-D model to honour the 'real data' of borehole intersections, while at the same time keeping memory of user defined changes allows for interpretations of geology and structure to be tested easily in the 3-D space. Updating and reinterpretation in the light of new data, for example from continued drilling programmes, is straightforward, and can be applied across all the parameters derived from the model.

- The process of contrasting models developed by different operators led to identification of errors in data input more quickly than if multiple operators were using one or other of the models independently. It also allowed difference in interpretation to be checked and clarified.

- The 3-D geological framework supports the effective adaptive management of the field through the modelling of structural fabric and extent of permeable and fractured units. This aids in defining the well targeting and reinjection strategies of the field operators. 


\subsection{ACKNOWLEDGEMENTS}

We acknowledge funding support for this project from Mighty River Power Ltd and their permission, along with that of Ngati Tuwharetoa Geothermal Assets Ltd, to publish these data. We thank Ben Pezaro and John Clark for their support. Thanks also go to A8D Trust, Putauaki Trust, Te Tahuna Putakuaki Trust and other local Maori trusts for access to borehole core and cuttings. Funding came from a Victoria University PhD scholarship to SDM, and financial support to Colin Wilson and Greg Bignall was initially provided via Foundation for Research Science and Technology (FRST) PROJ-20199-GEO-GNS "Harnessing New Zealand's Geothermal Resources: Hotter and Deeper", which is now part of the GNS Science CSA (Core Science Area) Geothermal Research Programme. Additional funding for CJNW came from the FRST Programme "Deep Geothermal Resources" through subcontracts from The University of Auckland, by courtesy of Mike O'Sullivan. Assistance from Samantha Alcaraz in use of Leapfrog Geothermal and subsequent editorial comments is greatly appreciated. 
Chapter 4 
CHAPTER 5

HYDROTHERMAL-MAGMATIC INFLUENCES ON THE GEOTHERMAL SYSTEM 


\section{$5.1 \quad$ INTRODUCTION}

In geothermal fields, different sources of water can contribute to hydrothermal activity and circulation systems. Hydrothermal fluids can be juvenile-magmatic or derived from seawater, metamorphic water, meteoric water, connate waters or be a mixture of these. Changes in hydrothermal processes and source fluids within a geothermal system can give an indication of the evolution of heat sources for that system. Fluid inclusions and stable isotopic tracers provide a means of investigating the nature and composition of the fluids involved in the hydrothermal processes and how these might have changed through time. At Kawerau the aim of this work was to look for evidence of magmatic influence in the hydrothermal fluids by examining alteration minerals within the field. This study aimed to resolve whether there were multiple episodes of heat input beneath the field that could be linked to earlier periods of magmatic activity beneath the area (e.g. the magmatic system supplying the Caxton Formation rhyolites).

This chapter reports new work and insights by the author, and couples these new data with results from Christenson (1987) and Absar (1988) in order to better understand the evolution of heat sources beneath the Kawerau area and potential sources of fluid into the overlying hydrothermal system. In addition to stable isotope analyses and fluid inclusion (FI) microthermometry, cathodoluminescence (CL) images were taken of the hydrothermal quartz used in the study to image growth zones in the crystals. Such techniques are used to understand the processes involved during precipitation of hydrothermal minerals, as the mineral growth can capture the signature of hydrothermal-magmatic interactions and the source of the parental fluids.

\subsubsection{Previous studies}

Detailed work has previously been undertaken by Christenson (1987) and Absar (1988) utilising hydrothermal alteration minerals in the Kawerau Geothermal Field. Christenson (1987) undertook a study on the fluid-mineral equilibria and evolution of the Kawerau geothermal system, including stable isotope and fluid inclusion analyses. Absar (1988) described the oxygen isotope chemistry, major and trace element chemistry and hydrothermal alteration of the basement rocks at Kawerau. 


\subsubsection{Hydrothermal alteration}

The Kawerau geothermal system is typical of continental-type hydrothermal systems (Chapter 1, section 1.3.). The present-day hydrothermal alteration minerals (Chapter 1, section 1.5.6.) in the Kawerau geothermal system are generally in equilibrium with the fluids from which they were deposited, with alteration mineralogy indicating the presence of a near-surface acid alteration zone (Tulloch, 1986). The shallow system changes with increasing depth to a neutral-pH assemblage (variously: wairakite, epidote, quartz, calcite, illite; indicative of temperatures $>240{ }^{\circ} \mathrm{C}$; Browne, 1978b), typical for geothermal systems in the TVZ.

Acid alteration is observed in core and cuttings from upper $(0-450 \mathrm{~m}$ depth) levels of the system. This alteration extends to variable depths $(<90 \mathrm{~m}, \mathrm{KA} 24 ;>450 \mathrm{~m}, \mathrm{KA29}$ : Christenson, 1987) and is marked by the presence of a low-temperature acidic mineral assemblages (e.g., halloysite, cristobalite, kaolinite, smectite, tridymite) inferred to be due to cool influx of meteoric water. The influence of cool meteoric water extends to as much as 750 $\mathrm{m}$ deep in some south-eastern wells (e.g., KA25, KA26 and KA29: Fig. 5.1) and $900 \mathrm{~m}$ depth in KA23 (Bignall and Harvey, 2005).

The presence of non-equilibrium mineral assemblages points to mineral overprinting and/or changing temperature and chemical conditions within the Kawerau reservoir. For example, Christenson (1987) described the occurrence of chalcedony and epidote in the same vein in KA10, chalcedony being indicative of $<190{ }^{\circ} \mathrm{C}$ fluid conditions (White and Hedenquist, 1990) whereas epidote first appears in Kawerau wells where downhole temperatures are $250-290$ ${ }^{\circ} \mathrm{C}$. There are however documented cases (i.e. Rotokawa: Price et al., 2011) where chalcedony is inferred to have formed at temperatures $>300{ }^{\circ} \mathrm{C}$. High- and low-temperature mineral assemblages also occur in KA16 and KA23, with the low-temperature assemblage overprinting neutral pH, high-temperature mineral assemblages (Bignall and Harvey, 2005). For the most part, however, thermal conditions inferred from the occurrence of hightemperature mineral assemblages are consistent with measured well temperatures, with the overprinting assemblages reflecting localised cool downflows.

Most of the producing wells at Kawerau are close to their boiling point for depth (BPD) conditions, and this is reflected in the nature of their hydrothermal alteration mineralogy. Illite clay (indicative of $>220{ }^{\circ} \mathrm{C}$ : Simmons et al., 1992) occurs from $\sim 300$ to $500 \mathrm{~m}$ drilled depth, which is consistent in most wells with BPD conditions. In some wells, however, the mineralogy indicate that cooler temperatures persist to greater depth, e.g. interlayered clays 
(indicative of $<160{ }^{\circ} \mathrm{C}$ : Browne, 1978b) occur to $\sim 500 \mathrm{~m}$ depth in KA25 at $\sim 746 \mathrm{~m}$ depth, with the first appearance of illite at $\sim 820 \mathrm{~m}$ depth (Bignall and Harvey, 2005).

There is evidence of cooling in some wells where epidote is present where measured temperatures are lower than $240{ }^{\circ} \mathrm{C}$ (e.g. KA22, $480 \mathrm{~m}, \mathrm{~T}_{\text {meas }}=210{ }^{\circ} \mathrm{C} ; \mathrm{KA} 29,487 \mathrm{~m}, \mathrm{~T}_{\text {meas }}$ $=120{ }^{\circ} \mathrm{C}$; KA34, $739 \mathrm{~m}, \mathrm{~T}_{\text {meas }}=195^{\circ} \mathrm{C}$ : Bignall and Harvey, 2005). As well as cooling in some areas, there are indications of heating, such as in the southeast part of the geothermal field, which may have been related to the (geologically recent) hydrothermal eruptions in that area (Nairn and Wiradiradja, 1980).

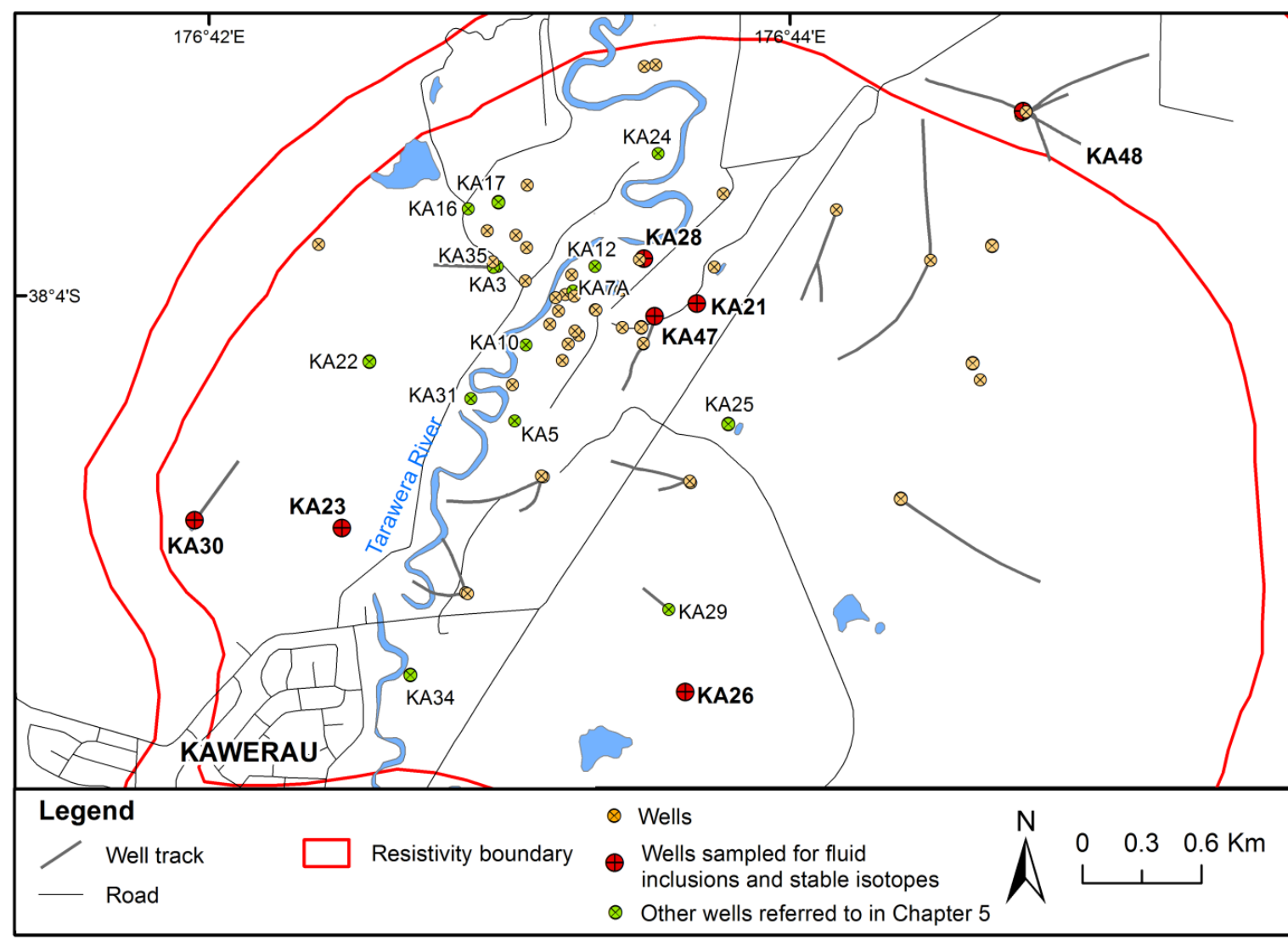

Figure 5.1 Location of wells in the Kawerau Geothermal Field, with wells sampled for fluid inclusions and stable isotopes highlighted. The approximate resistivity boundary zone at about $500 \mathrm{~m}$ depth (after Allis, 1997) is shown in red.

Absar (1988) describes three hydrothermal regimes and associated alteration assemblages zones within greywacke basement below the field. These three zones will be returned to in later discussion when addressing implications of stable isotope analyses and inferences on timing of heat input.

- The earliest hydrothermal regime was responsible for the formation of prehnite and wairakite, predominantly in the form of veins in the basement. This 'wairakite-prebnite zone' is characterised by a lack of epidote inferred to be due to high levels of $\mathrm{CO}_{2}$. 
- Absar (1988) proposed that the formation of the wairakite-prehnite zone was followed by a period of high gas $\left(\mathrm{CO}_{2}\right)$ overpressures which, when released in a hydraulic fracturing event, resulted in massive precipitation of calcite. This led to the development of a mineral assemblage with abundant calcite in the southern part of the field. These 'calcite zone' rocks are typically less altered and hydrothermal phases (mainly calcite and quartz) generally occur within veins. The author inferred the hydrothermal events responsible for the formation of wairakite-prehnite and calcite zones are mainly confined to the basement rocks in the southern part of the field.

- The modern mineral assemblage comprising calcite, quartz, calc-silicates, illite and adularia is characterised by the absence of prehnite and a greater abundance of epidote and clinozoisite than in earlier assemblages. Alteration is related to the youngest (Quaternary) faulting which enabled fluids to move into the central and northern parts of the field after flow was inhibited in the southern part of the field due to diminished permeability. This 'calcite-epidote zone' assemblage is in equilibrium with the present-day fluid.

A selected number of wells were chosen for this study to represent both the main upflow zone and more marginal areas. They were also chosen where their stratigraphy is most well defined by dating, either in the well itself or nearby (Chapter 2), allowing for the timing of events to be more tightly constrained. These wells are grouped into four categories: southwest, middle, northeast and south field to facilitate discussion later in this chapter. The general pattern of alteration in the wells studied in this chapter (Fig. 5.1) is as follows:

Southwest field (KA23, 30): Increasing intensity of alteration with depth, with the deep alteration minerals comprising chlorite, illite, quartz, pyrite, and rare epidote at $>800 \mathrm{~m}$ depth.

Middle field $(K A 21,28,47)$ : Alteration intensity and rank increases with depth, passing to a high-temperature assemblage at around $700 \mathrm{~m}$ depth, with epidote and wairakite veining, and epidote replacing primary plagioclase crystals.

Northeast field (KA48): Alteration intensity increases with depth. Alteration rank increases with depth, with smectite, passing through illite-smectite $(\sim 300 \mathrm{~m})$ to illite $(\sim 800 \mathrm{~m})$ with increasing depth and temperature. No high-temperature minerals (i.e. wairakite or epidote) are present.

South field (KA26): Moderate alteration, increasing somewhat in intensity with depth. Primary plagioclase and ferromagnesian minerals are pseudomorphed by albite, calcite, chlorite and 
illite. No high-temperature minerals (i.e. wairakite or epidote) are present. Calcite alteration is dominant.

\subsection{TECHNIQUES AND RESULTS}

This section describes the techniques utilised to help understand the processes involved during precipitation of hydrothermal minerals, as these minerals hold the signature of hydrothermal-magmatic interactions and the source of the fluids from which they formed.

Techniques used were stable isotope analyses, fluid inclusions (FI) microthermometry and cathodoluminescence (CL) microscopy. Samples of bladed calcite and vein quartz were collected from drill cuttings in seven wells (Fig. 5.1). The wells were selected where the geology was well constrained by $\mathrm{U}-\mathrm{Pb}$ ages (Chapter 2) and to be representative of both the upflow and marginal zones of the geothermal system. Where possible, CL imagery and fluid inclusions and stable isotope analyses were undertaken on the same sample intervals to allow for comparison of data (Table 5.1).

Table 5.1 Kawerau hydrothermal mineral samples selected and hand-picked for analyses. Fm = Formation, qz = quartz, $\mathrm{cc}=$ calcite.

\begin{tabular}{|c|c|c|c|c|c|c|c|}
\hline Well & $\begin{array}{l}\text { Depth } \\
\text { (mRF) }\end{array}$ & Mineral & CL & $\begin{array}{l}\text { Fluid } \\
\text { inclusions }\end{array}$ & $\begin{array}{l}\text { Isotopes } \\
\text { analysed }\end{array}$ & Comments & Formation \\
\hline KA21 & 262 & Vein qz & $\checkmark$ & $\checkmark$ & $\delta^{18} \mathrm{O}$ & & Matahina ignimbrite \\
\hline KA21 & 475 & Vein qz & & $\checkmark$ & $\delta^{18} \mathrm{O}$ & & Caxton Fm extrusive \\
\hline \multirow[t]{2}{*}{ KA21ST } & 765 & Platy cc & $\checkmark$ & $\checkmark$ & $\delta^{18} \mathrm{O}+\delta^{13} \mathrm{C}$ & & Kawerau Andesite \\
\hline & & Vein qz & & $\checkmark$ & $\delta^{18} \mathrm{O}$ & & \\
\hline \multirow[t]{2}{*}{ KA21 } & 829 & Platy cc & & $\checkmark$ & $\delta^{18} \mathrm{O}+\delta^{13} \mathrm{C}$ & & Te Teko Fm \\
\hline & & Vein qz & $\checkmark$ & $\checkmark$ & $\delta^{18} \mathrm{O}$ & & \\
\hline \multirow[t]{2}{*}{$\mathrm{KA} 23$} & 262 & Platy cc & & $\checkmark$ & $\delta^{18} \mathrm{O}+\delta^{13} \mathrm{C}$ & & Matahina ignimbrite \\
\hline & & Vein qz & $\checkmark$ & $\checkmark$ & $\delta^{18} \mathrm{O}$ & & \\
\hline \multirow[t]{2}{*}{ KA23 } & 348 & Platy cc & & $\checkmark$ & $\delta^{18} \mathrm{O}+\delta^{13} \mathrm{C}$ & & Matahina ignimbrite \\
\hline & & Vein qz & $\checkmark$ & $\checkmark$ & $\delta^{18} \mathrm{O}$ & & \\
\hline KA23 & 658 & Vein qz & & $\checkmark$ & & & Te Teko Fm $1.34 \mathrm{Ma}$ \\
\hline KA23 & 814 & Vein qz & $\checkmark$ & $\checkmark$ & & & Te Teko Fm $1.46 \mathrm{Ma}$ \\
\hline \multirow[t]{2}{*}{ KA26 } & 543 & Platy cc & & $\checkmark$ & $\delta^{18} \mathrm{O}+\delta^{13} \mathrm{C}$ & & Te Teko Fm \\
\hline & & Vein qz & $\checkmark$ & $\checkmark$ & & & \\
\hline KA28 & 656 & $\mathrm{Qz}$ & $\checkmark$ & $\checkmark$ & & primary volcanic qz & Caxton Fm intrusive \\
\hline KA30 & 540 & Platy cc & & $\checkmark$ & $\delta^{18} \mathrm{O}+\delta^{13} \mathrm{C}$ & & Raepahu Fm \\
\hline
\end{tabular}




\begin{tabular}{|c|c|c|c|c|c|c|c|}
\hline Well & $\begin{array}{l}\text { Depth } \\
\text { (mRF) }\end{array}$ & Mineral & CL & $\begin{array}{l}\text { Fluid } \\
\text { inclusions }\end{array}$ & $\begin{array}{l}\text { Isotopes } \\
\text { analysed }\end{array}$ & Comments & Formation \\
\hline & & Vein qz & & $\checkmark$ & $\delta^{18} \mathrm{O}$ & & \\
\hline \multirow[t]{2}{*}{ KA30 } & 885 & $\mathrm{Cc}$ & & $\checkmark$ & & primary volcanic qz & Onepu Fm intrusive \\
\hline & & $\mathrm{Qz}$ & $\checkmark$ & $\checkmark$ & & & \\
\hline KA47 & 365 & Vein qz & $\checkmark$ & $\checkmark$ & $\delta^{18} \mathrm{O}$ & & Tahuna Fm (tuff) \\
\hline KA47 & 505 & Vein qz & $\checkmark$ & $\checkmark$ & $\delta^{18} \mathrm{O}$ & & Tahuna Fm (tuff) \\
\hline KA48 & 520 & Platy cc & $\checkmark$ & $\checkmark$ & $\delta^{18} \mathrm{O}+\delta^{13} \mathrm{C}$ & & Karaponga Fm \\
\hline KA48 & 775 & Platy cc & & $\checkmark$ & $\delta^{18} \mathrm{O}+\delta^{13} \mathrm{C}$ & & Raepahu Fm \\
\hline \multirow[t]{2}{*}{ KA48 } & 840 & Platy cc & & $\checkmark$ & $\delta^{18} \mathrm{O}+\delta^{13} \mathrm{C}$ & & Te Teko Fm \\
\hline & & Vein qz & $\checkmark$ & $\checkmark$ & $\delta^{18} \mathrm{O}$ & & \\
\hline
\end{tabular}

\subsubsection{Cathodoluminescence}

Cathodoluminescence (CL) is the emission of photons of characteristic wavelengths from a material that is under high-energy electron bombardment (Gotze and Kemp, 2009: Fig. 5.2). The electron beam is typically produced in an electron microprobe or scanning electron microscope or in a cathodoluminescence microscopy attachment to a petrographic microscope (Gotze and Kemp, 2009). The nature of CL in a material is a complex function of composition, lattice structure and superimposed strain or damage on the structure of the material.

\section{Primary electron beam}

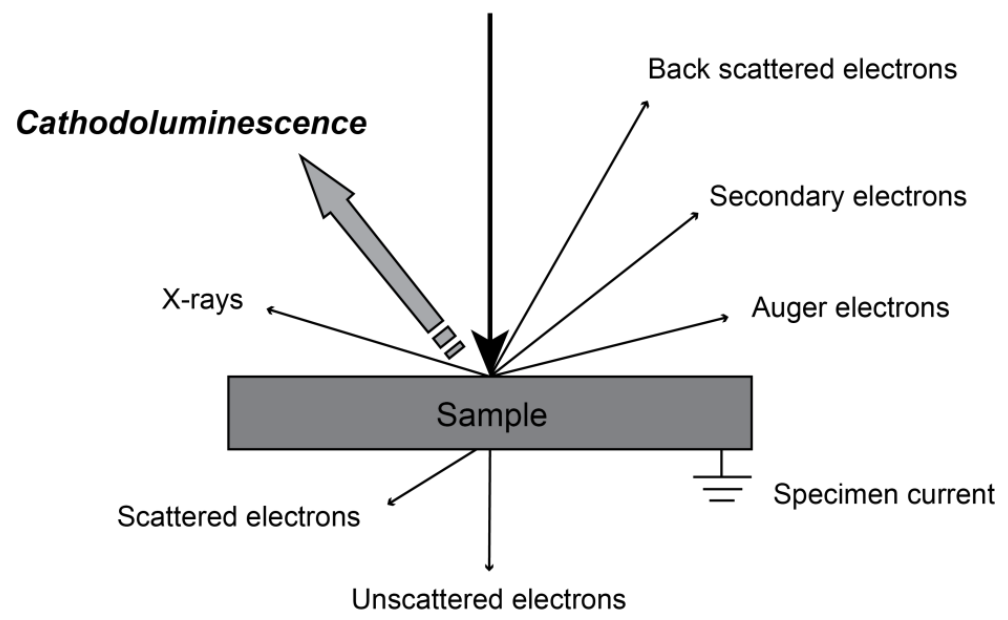

Figure 5.2 Schematic illustration of interactions of an electron beam with a solid surface (from Gotze and Kemp, 2009).

CL patterns can be used to reveal internal structures, growth zoning and lattice defects in quartz crystals that are not discernible by other petrographic means. During the growth of 
hydrothermal quartz from solution, variations of the physiochemical conditions can result in crystal zoning (Gotze et al., 2001; Gotze and Kempe, 2009). Imaging of this zoning by CL allows for the reconstruction of growth or dissolution events, or reveals changes in fluid composition (e.g. Fig. 5.3). The causes of zoning in quartz are not well understood, but can be related to variations in trace-element concentrations or to intrinsic defects caused by effects of the growth conditions (Gotze et al., 2001). Rusk et al. (2008) studied the trace element distribution in hydrothermal quartz in relation to CL patterns. They concluded that fluctuations in CL intensity corresponded most consistently to fluctuations in $\mathrm{Ti}$ or $\mathrm{Al}$. Wilkinson (2001) suggests that CL petrography is a useful tool for resolving multiple stages of mineral growth, because it reflects the changes in fluid chemistry, temperature and mineral structure. It may be possible that through CL one could resolve the relative time of formation of different inclusion generations and link these to changes in fluid chemistry and temperature.

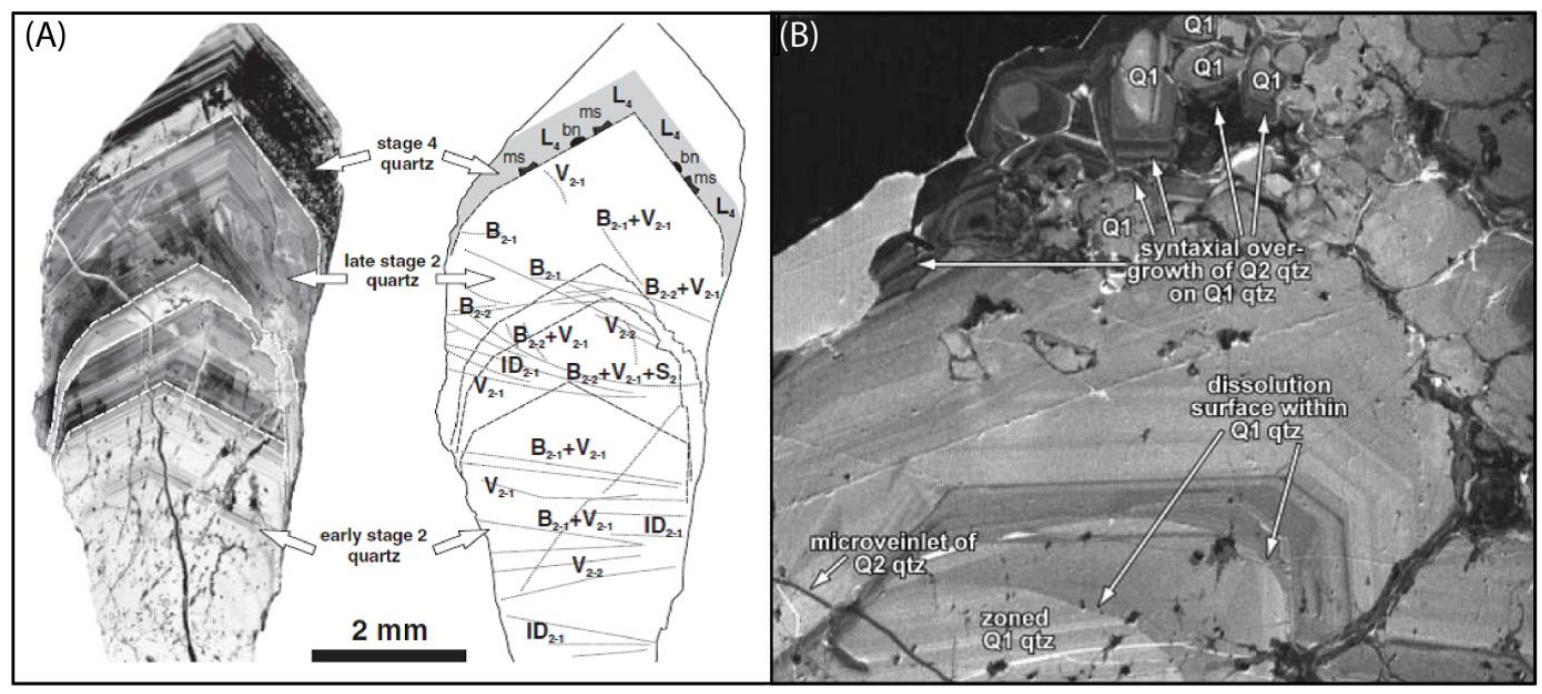

Figure 5.3 Published examples of CL imagery in hydrothermal quartz highlighting growth and dissolution events. (A) Image of a porphyry-Cu vein quartz sample from the El Teniente porphyry deposit, Chile acquired by SEM-CL (from Klemm et al., 2007). This image shows growth zones with fluid inclusion assemblage, the details of which will not be covered here. (B) Image of a porphyry-Cu vein quartz sample from the Bingham porphyry deposit, USA acquired by SEM-CL (from Landtwing and Pettke, 2005). The bright-luminescent hydrothermal quartz generation Q1, forming the stockwork veins, is overgrown or truncated by dark-luminescent Q2 quartz associated with the bulk of $\mathrm{Cu}$ ore deposition.

For the work reported here, optical CL observations were made on vein quartz samples (Table 5.1) using double polished thin sections on a Cambridge Image Technology Ltd. CL8200 Mk5-1 instrument at Waikato University, Hamilton, New Zealand. Optimum luminescence occurred at $16 \mathrm{kV}$ accelerating voltage and a gun current of $450 \mu \mathrm{A}$. Images were captured using a Nikon digital camera using NIS Elements D camera software. Images acquired were used to aid fluid inclusion interpretation (section 5.2.2.2.) and all images acquired can be found in Electronic Appendix 9 


\subsubsection{Fluid inclusions}

Fluid inclusion can provide data regarding the subsurface temperatures and fluid conditions during growth of the host mineral. Such data can provide insights into whether the geothermal system is chemically or thermally stable, and evidence for past changes. The most commonly used non-destructive analytical technique for fluid inclusions is microthermometry, where observations of phase change (i.e. ice melting) can be used to constrain the physical properties of the fluid at the time of trapping (Brown, 1998).

There are several assumptions on which fluid inclusion microthermometry is based (Roedder and Bodnar, 1980; Roedder, 1984):

- At the time of trapping, the inclusion sampled a homogenous, single phase environment.

- $\quad$ The space in which the fluid was trapped does not change volume after sealing

- The inclusion is effectively sealed chemically from further interaction with the host mineral and surrounds

- The effects of pressure are insignificant or known (which is the case for geothermal samples).

- The origin of the inclusion is known.

Fluid inclusions in this study are classified as described in Bodnar (2003), which relates the timing of formation of the inclusion relative to that of the host mineral (Fig. 5.4).

- Primary inclusions - formed during, and as a direct result of, growth of the surrounding host crystal.

- Secondary inclusions - after a crystal forms, it can fracture and fluid enter the fracture. This can become trapped as inclusions as the fracture heals.

- Pseudosecondary inclusions - if fracturing occurs during growth of the crystal, inclusions may be trapped during continued crystal growth. 


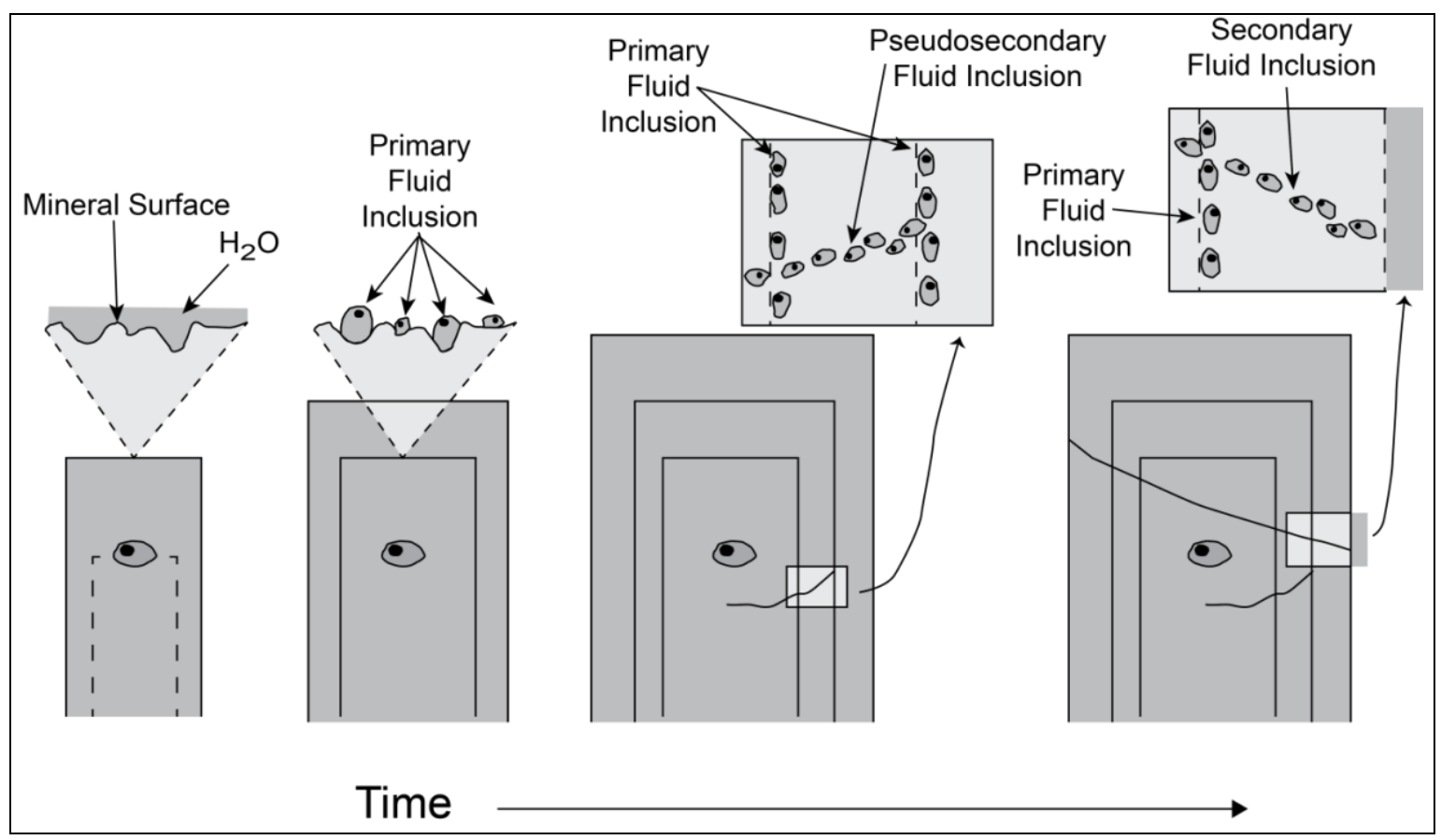

Figure 5.4 Schematic representation showing the formation of primary, secondary and pseudosecondary inclusions during crystal growth (from Bodnar, 2003).

In general, when dealing with fluid inclusions, it can be difficult to determine the temporal classification at times. Fluid Inclusion Assemblages (FIA) can be used to minimise the emphasis on the primary, secondary, and pseudosecondary classification of inclusions. These describe a group of inclusions that were all trapped at the same time (Bodnar, 2003). A FIA represents a 'fluid event' in the history of the system, where all the inclusions in the FIA were trapped at approximately the same temperature, pressure and fluid composition. Thus, the FIA is defined as group of inclusions trapped simultaneously in a single event, adhering to the petrographic definitions of Goldstein (2001).

\subsubsection{Fluid inclusion methodology}

Microthermometry heating and freezing experiments were carried out on $>1080$ fluid inclusions hosted in vein quartz and in loose bladed calcite crystals from selected wells (Table 5.1) at Kawerau. Homogenisation $\left(T_{h}\right)$ and melting temperatures $\left(T_{m}\right)$ were measured using a Linkam THMSG600 heating and cooling stage controlled by Linksys 32 DV software located at GNS Science, Wairakei, New Zealand.

Fluid inclusion sizes in all samples are typically $<10 \mu \mathrm{m}$, though some are up to $100 \mu \mathrm{m}$. From the shapes of some inclusions it is inferred that necking has occurred. This is a postentrapment process where large irregular inclusions tend towards equilibrium by splitting into several smaller, more equant inclusions (Diamond, 2003). These inclusions were considered 
unreliable for microthermometry measurements and avoided. Where measurements were made of necked inclusions, or possibly leakage of inclusions has occurred, or the measurements were isolated, they are included in the tables in Electronic Appendix 8, but are not included in the summary tables (Tables 5.2 to 5.8) or used in this chapter.

The measurement of multiple Fluid Inclusion Assemblages (FIA) from wells across the field reveals generally non-systematic variation in $\mathrm{T}_{h}$ and $\mathrm{T}_{\mathrm{m}}$, indicating a complex fluid history and trapping of fluids with varying temperature and salinity (although generally dilute). At room temperature most fluid inclusions were 2-phase, with coexisting liquid and a vapour bubble. Most of the fluid inclusions were fluid-rich (liquid forming $\sim 85 \%$ of the fluid inclusion at room temperature), although rare vapour-rich inclusions were present in one sample (Fig. 5.5). Upon heating, all fluid inclusions homogenised to liquid. Daughter salts or minerals were not observed, implying that the trapped fluids have salinities $<23.3 \mathrm{wt} . \% \mathrm{NaCl}$ equivalent (Roedder, 1984). During the freezing measurements $\mathrm{CO}_{2}$-clathrate was not observed, implying that dissolved gas concentrations in the trapped fluids were $<3.7$ wt. $\% \mathrm{CO}_{2}$ (Hedenquist and Henley, 1985). In the absence of $\mathrm{CO}_{2}$-clathrates, $\mathrm{CO}_{2}$ in solution can depress the ice melting temperature by up to $1.5^{\circ} \mathrm{C}$ (Hedenquist and Henley, 1985), resulting in false apparent salinities of up to $2.6 \mathrm{NaCl}$ eq. wt.\%. Apparent salinities for fluid inclusions, which are expressed as $\mathrm{NaCl}$ equivalent $\left(\mathrm{NaCl}\right.$ eq. wt. \%), were calculated assuming $\mathrm{H}_{2} \mathrm{O}-$ $\mathrm{NaCl}$ systematics and 0 wt. \% $\mathrm{CO}_{2}$ and using the equations of Bodnar (1993). 


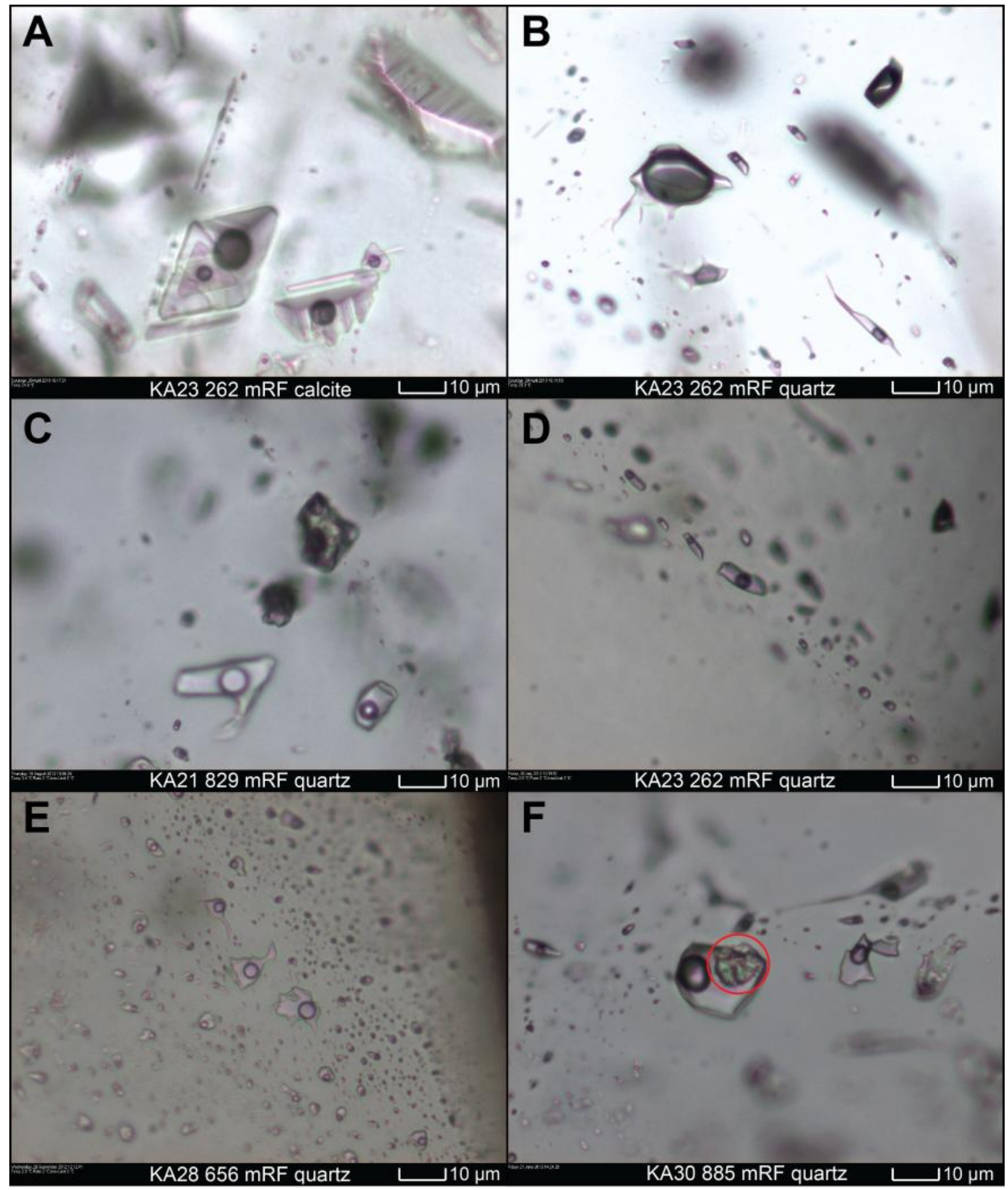

Figure 5.5 Representative fluid inclusions from several wells in the Kawerau Geothermal Field. A) Liquidrich primary fluid inclusions mimicking the basal pinacoid form in calcite. B) Coeval population of liquid-rich and vapour-rich secondary fluid inclusions in quartz. C) Liquid-rich primary fluid inclusions in quartz. D) Secondary fluid inclusions along a fracture plane. E) Secondary fluid inclusions in a fracture cutting primary volcanic quartz. F) Liquid-rich fluid inclusion with included illite (circled in red).

Most of the fluid inclusions in vein quartz were secondary inclusions, many trapped along healed fractures (Fig. 5.5). The calcite samples were all of the platy, bladed form (Fig. 5.6). The inclusions mimic the basal pinacoid form (Fig. 5.5) and lie coplanar with their host crystal, indicating that the inclusions are primary in origin (Simmons and Christenson, 1994). Rare inclusions include an incidental clay mineral (KA30, 885 mRF; Fig. 5.5F) which may be illite (cf. Simpson et al., 2010). 
A summary of the FIA measurements is found in Tables 5.2 to 5.8. The full tabulated results are found in Electronic Appendix 8 and the images of the samples and fluid inclusions plates are found in Electronic Appendix 7.

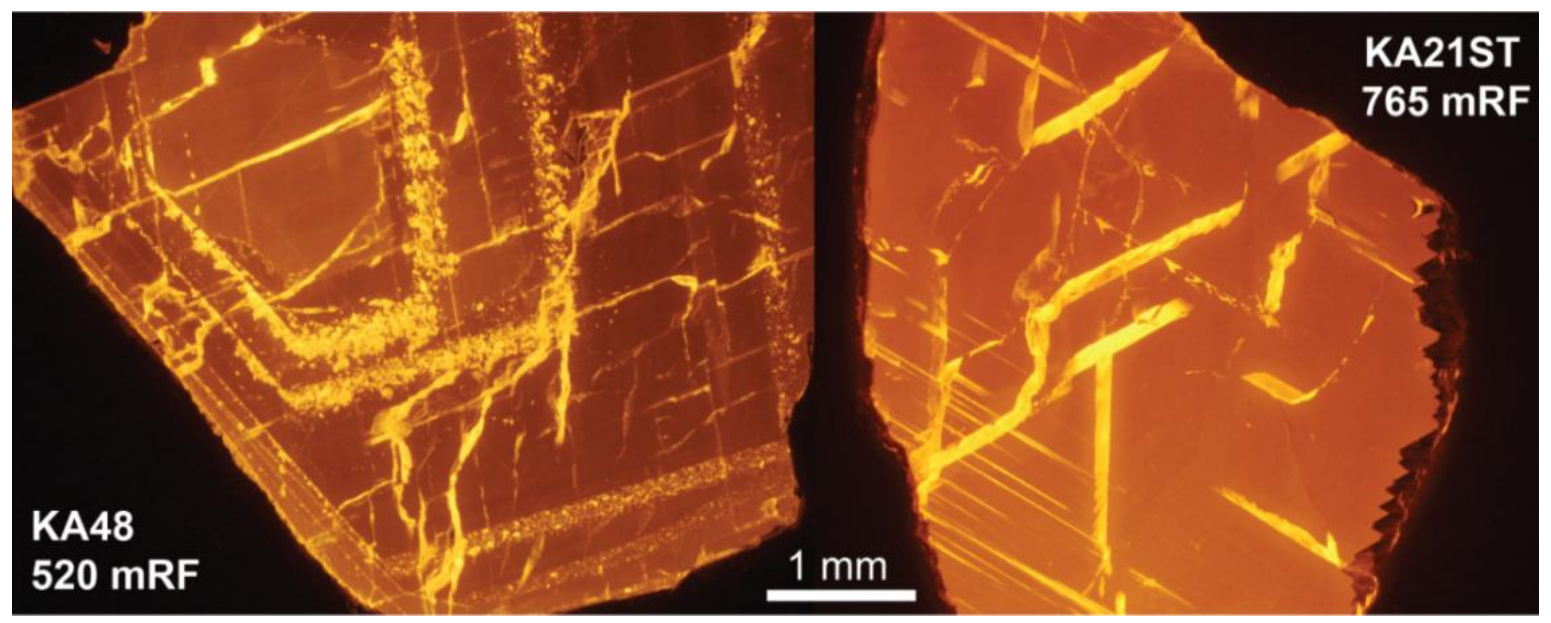

Figure 5.6 Growth zones of platy calcite under cathodoluminescence.

\subsubsection{Fluid inclusion results}

A complete table of fluid inclusion data can be found in Electronic Appendix 8, and the associated fluid inclusion plates and corresponding CL images in Electronic Appendices 7 and 9 respectively. This section reports a summary of the fluid inclusion results.

Homogenisation temperatures often overlap for primary (p), pseudosecondary (ps) and secondary (s) inclusions and most fall in a range from 212 to $285^{\circ} \mathrm{C}$ with many FIA having narrow ranges of $5-10{ }^{\circ} \mathrm{C}$. Final ice melting temperatures mostly fall between -0.2 to $-0.8{ }^{\circ} \mathrm{C}$, corresponding to apparent salinities of $<1.4$ wt. $\% \mathrm{NaCl}$ eq. (Bodnar, 1993).

In Figs. 5.7 - 5.17, the mean $\mathrm{T}_{\mathrm{h}}$ and $\mathrm{T}_{\mathrm{m}}$ values are plotted for each FIA. In Figs. 5.8, 5.10, 5.11, 5.16 and 5.17, FIA mean $\mathrm{T}_{\mathrm{h}}$ values are plotted against the interpreted natural state well temperature (i.e. temperature profiles prior to development for electricity: MRP, 2013), the BPD for pure water under hydrodynamic conditions and the BPD for a solution containing 3.7 wt. $\% \mathrm{CO}_{2}$. In Figs. 5.7, 5.9, 5.13 and 5.15, representative CL images are shown (all CL images are presented in Electronic Appendix 9), with the mean $\mathrm{T}_{\mathrm{h}}$ and $\mathrm{T}_{\mathrm{m}}$ values of each FIA indicated on the image. The CL images were useful in determining the origin (i.e., primary) of the fluid inclusions, and how they relate to the growth of the hydrothermal quartz.

Heating and melting measurements were made on fluid inclusions in quartz and/or calcite samples at six depths in KA21 and side-track KA21ST. At room temperature fluid inclusions were fluid-rich and two phase, with coexisting liquid and a vapour bubble. The summary 
results of FIA from these samples are compiled in Table 5.2. Representative examples from KA21 of FIA with corresponding CL image are shown in Fig. 5.7. KA21 bivariant plots of $T_{h}$ and $T_{m}$ values and $T_{h}$ plotted against vertical depth can be found in Fig. 5.9.

Table 5.2 Fluid inclusion microthermometry results from quartz and bladed calcite samples collected from well KA21 and KA21ST drill cuttings. $\mathrm{T}_{\mathrm{h}}=$ homogenisation temperature; $\mathrm{T}_{\mathrm{m}}=$ final ice melting temperature; $\mathrm{NaCl}$ eq. wt. $\%$ = apparent salinity (Bodnar, 1993); FIA = fluid inclusion assemblage (FIA numbers are arbitrarily assigned and do not reflect paragenetic sequence); $\mathrm{p}=$ primary fluid inclusion; $\mathrm{ps}=$ pseudosecondary fluid inclusion and $\mathrm{s}=$ secondary fluid inclusion.

\begin{tabular}{|c|c|c|c|c|c|c|c|c|c|c|c|}
\hline Well & $\begin{array}{l}\text { Depth } \\
\text { mRF }\end{array}$ & Sample & Type & FIA & $\mathrm{T}_{\mathrm{h}} \underset{{ }^{\circ} \mathrm{C}}{\text { range }}$ & $\mathrm{n}$ & $\underset{{ }^{\circ} \mathrm{C}}{\text { Avg. }}$ & $\underset{{ }^{\circ} \mathrm{C}}{\mathrm{T}_{\mathrm{m}} \text { range }}$ & $\mathrm{n}$ & $\underset{{ }^{\circ} \mathrm{C}}{\text { Avg. }}$ & $\begin{array}{c}\mathrm{NaCl} \text { eq } \\
\text { (wt. \%) }\end{array}$ \\
\hline \multirow[t]{6}{*}{ KA21 } & 262 & Quartz & s & FIA1 & 212 to 219 & 7 & 214 & -0.3 & 7 & -0.3 & 0.5 \\
\hline & & & s & FIA3 & 212 to 218 & 5 & 214 & -0.3 & 5 & -0.3 & 0.5 \\
\hline & & total & & FIA1, 3 & 212 to 219 & 12 & 214 & -0.3 & 12 & -0.3 & 0.5 \\
\hline & & & s & FIA2 & 232 to 240 & 3 & 237 & -0.3 & 3 & -0.3 & 0.5 \\
\hline & & & $\mathrm{s}$ & FIA4 & 252 to 265 & 3 & 260 & -0.3 & 3 & -0.3 & 0.5 \\
\hline & & & $\mathrm{s}$ & FIA5 & 202 to 206 & 3 & 204 & -0.3 & 3 & -0.3 & 0.5 \\
\hline \multirow[t]{7}{*}{ KA21 } & 475 & Quartz & s & FIA2 & 218 & 4 & 218 & -0.2 & 4 & -0.2 & 0.4 \\
\hline & & & s & FIA4 & 212 to 218 & 10 & 216 & -0.2 & 4 & -0.2 & 0.4 \\
\hline & & & $\mathrm{s}$ & FIA5 & 212 to 218 & 10 & 214 & -0.2 & 10 & -0.2 & 0.4 \\
\hline & & & s & FIA6 & 212 to 218 & 3 & 214 & -0.2 & 3 & -0.2 & 0.4 \\
\hline & & total & s & FIA2, $4-6$ & 212 to 218 & 27 & 216 & -0.2 & 27 & -0.2 & 0.4 \\
\hline & & & s & FIA3 & 235 to 250 & 4 & 242 & -0.2 & 4 & -0.2 & 0.4 \\
\hline & & & $\mathrm{p}$ & FIA1 & 248 to 278 & 7 & 259 & -0.2 & 7 & -0.2 & 0.4 \\
\hline \multirow[t]{15}{*}{ KA21ST } & 765 & Quartz & $\mathrm{p}$ & FIA1 & 260 to 282 & 12 & 273 & -0.1 & 12 & -0.1 & 0.2 \\
\hline & & & $\mathrm{p}$ & FIA2 & 268 to 280 & 9 & 273 & -0.2 & 9 & -0.2 & 0.4 \\
\hline & & & $\mathrm{p}$ & FIA3 & 268 to 285 & 10 & 278 & -0.2 & 10 & -0.2 & 0.4 \\
\hline & & total & $\mathrm{p}$ & FIA1 - 3 & 260 to 285 & 31 & 275 & -0.1 to -0.2 & 31 & -0.2 & 0.2 to 0.4 \\
\hline & & & $\mathrm{s}$ & FIA5 & 265 to 278 & 10 & 271 & -0.3 & 10 & -0.3 & 0.5 \\
\hline & & & s & FIA7 & 270 & 4 & 270 & -0.3 & 4 & -0.3 & 0.5 \\
\hline & & & s & FIA9 & 270 to 272 & 5 & 271 & -0.2 & 5 & -0.2 & 0.4 \\
\hline & & & s & FIA11 & 270 to 272 & 4 & 271 & -0.3 to -0.5 & 4 & -0.5 & 0.5 to 0.9 \\
\hline & & total & s & FIA5, 7, 9, 11 & 265 to 278 & 23 & 271 & -0.2 to -0.3 & 23 & -0.3 & 0.4 to 0.5 \\
\hline & & & s & FIA4 & 260 to 265 & 16 & 262 & -0.3 & 16 & -0.3 & 0.5 \\
\hline & & & s & FIA6 & 255 to 264 & 9 & 258 & -0.3 & 9 & -0.3 & 0.5 \\
\hline & & & s & FIA8 & 258 to 260 & 4 & 259 & -0.3 & 4 & -0.3 & 0.5 \\
\hline & & & s & FIA10 & 265 to 270 & 4 & 267 & -0.3 & 4 & -0.3 & 0.5 \\
\hline & & & s & FIA12 & 256 to 259 & 5 & 257 & -0.4 & 5 & -0.4 & 0.7 \\
\hline & & total & s & FIA $4,6,8,10,12$ & 255 to 264 & 38 & 261 & -0.3 to -0.4 & 38 & -0.3 & 0.5 to 0.7 \\
\hline \multirow[t]{2}{*}{ KA21ST } & 765 & Calcite & $\mathrm{p}$ & FIA1 & 278 to 286 & 18 & 281 & -0.3 to -0.4 & 18 & -0.3 & 0.5 to 0.7 \\
\hline & & & $\mathrm{p}$ & FIA3 & 281 to 282 & 4 & 282 & -0.4 & 4 & -0.4 & 0.7 \\
\hline
\end{tabular}


Chapter 5

\begin{tabular}{|c|c|c|c|c|c|c|c|c|c|c|c|}
\hline Well & $\begin{array}{l}\text { Depth } \\
\text { mRF }\end{array}$ & Sample & Type & FIA & $\mathrm{T}_{\mathrm{h}}$ range & $\mathbf{n}$ & $\underset{{ }^{\circ} \mathrm{C}}{\text { Avg. }}$ & $\mathrm{T}_{\mathrm{m}}$ range & $\mathrm{n}$ & $\underset{ }{\text { Avg. }}$ & $\begin{array}{c}\mathrm{NaCl} \text { eq } \\
\text { (wt. \%) }\end{array}$ \\
\hline & & total & $\mathrm{p}$ & FIA1, 3 & 278 to 286 & 22 & 281 & 0.3 to -0.4 & 22 & -0.3 & 0.5 to 0.7 \\
\hline & & & $\mathrm{p}$ & FIA2 & 295 to 342 & 4 & 326 & -0.4 to -0.5 & 4 & -0.5 & 0.7 to 0.9 \\
\hline \multirow[t]{11}{*}{ KA21 } & 829 & Quartz & $\mathrm{p}$ & FIA2 & 278 to 281 & 10 & 280 & -0.3 & 10 & -0.3 & 0.5 \\
\hline & & & $\mathrm{p}$ & FIA3 & 280 to 283 & 11 & 281 & -0.3 & 11 & -0.3 & 0.5 \\
\hline & & total & $\mathrm{p}$ & FIA $2-3$ & 278 to 283 & 21 & 280 & -0.3 & 21 & -0.3 & 0.5 \\
\hline & & & $\mathrm{s}$ & FIA5 & 275 to 284 & 8 & 276 & -0.6 & 8 & -0.6 & 1 \\
\hline & & & $\mathrm{s}$ & FIA7 & 280 to 310 & 6 & 288 & -0.3 & 6 & -0.3 & 0.5 \\
\hline & & & s & FIA8 & 280 to 285 & 6 & 283 & -0.2 to -0.4 & 6 & -0.3 & 0.4 to 0.7 \\
\hline & & total & s & FIA5, 7,8 & 275 to 285 & 20 & 282 & -0.2 to -0.6 & 20 & -0.3 & 0.4 to 1.0 \\
\hline & & & s & FIA4 & 263 to 265 & 4 & 264 & -0.3 & 4 & -0.6 & 0.5 \\
\hline & & & s & FIA6 & 264 to 268 & 6 & 266 & -0.5 & 6 & -0.5 & 0.9 \\
\hline & & total & s & FIA4, 6 & 263 to 268 & 10 & 265 & -0.3 to -0.5 & 10 & -0.6 & 0.5 to 0.9 \\
\hline & & & ps & FIA1 & 283 to 285 & 9 & 284 & -0.3 & 9 & -0.3 & 0.5 \\
\hline KA21 & 829 & Calcite & $\mathrm{p}$ & FIA1 & 285 to 295 & 6 & 289 & -0.5 to -0.6 & 6 & -0.6 & 0.9 to 1.0 \\
\hline
\end{tabular}



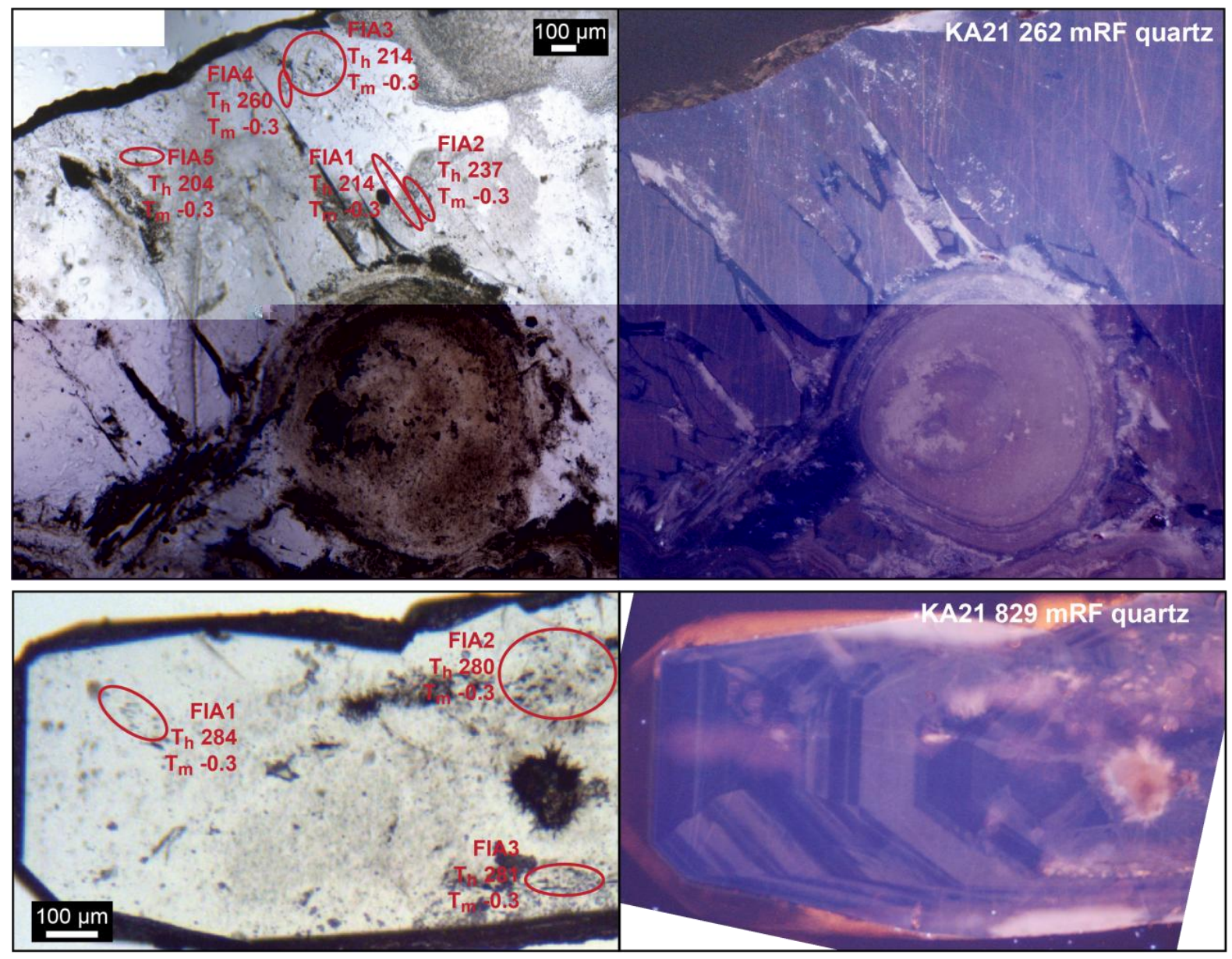

Figure 5.7 Mean homogenisation $\left(T_{h}\right)$ and melting $\left(T_{m}\right)$ temperatures for FIA in KA21 with corresponding CL image. The sample from $262 \mathrm{mRF}$ shows chalcedony lining a vein margin and infilled with open-space euhedral quartz growth. 


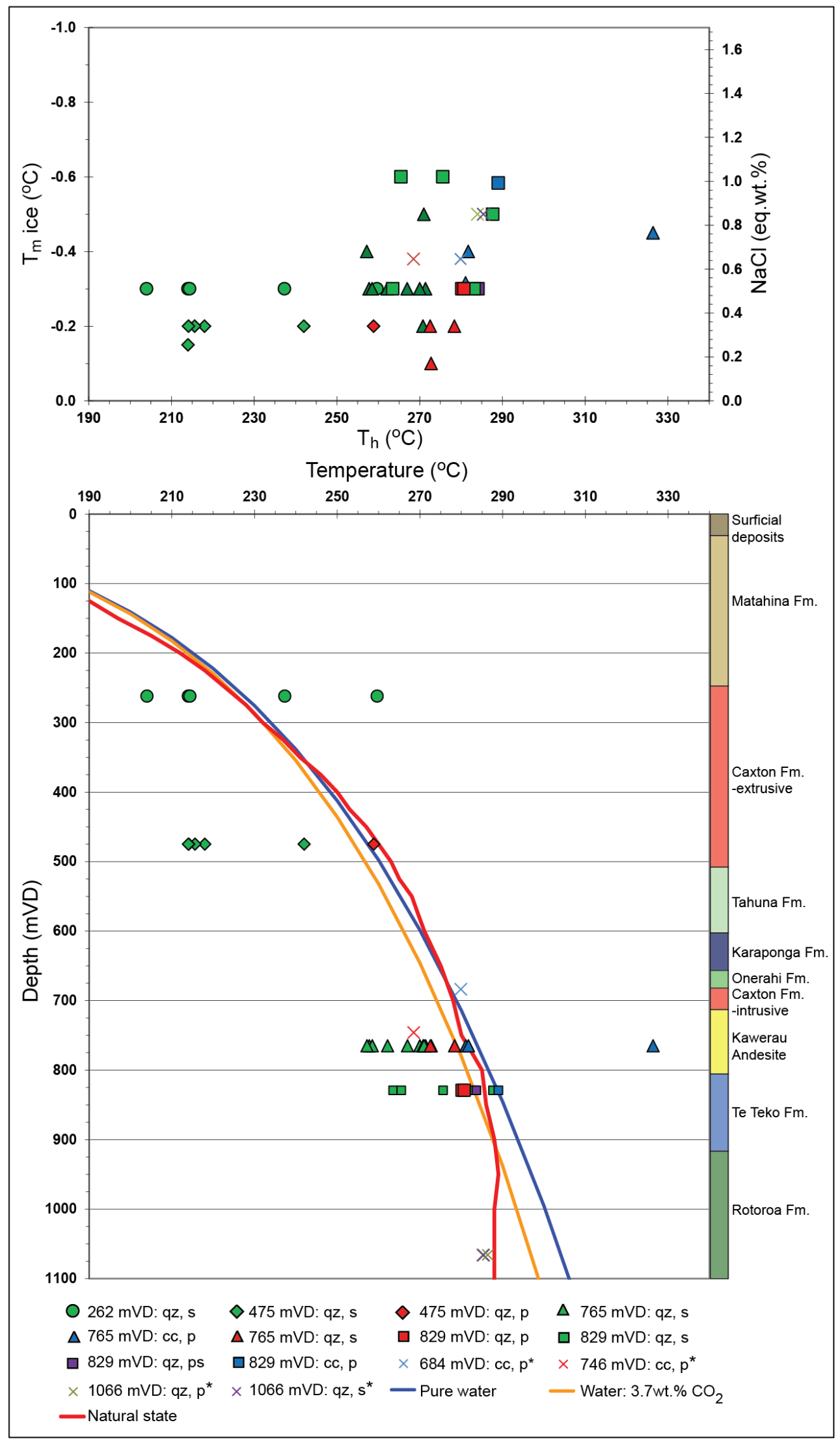

Figure 5.8 Fluid inclusion results from KA21. Each data point represents the mean of a FIA (Table 5.2). Top: Bivariant plot showing measured homogenisation $\left(\mathrm{T}_{\mathrm{h}}\right)$ and melting $\left(\mathrm{T}_{\mathrm{m}}\right)$ temperatures with equivalent salinity (eq. wt. $\% \mathrm{NaCl}$ ). Bottom: Homogenisation temperatures $\left(\mathrm{T}_{\mathrm{h}}\right)$ plotted against vertical depth. The curves represents the BPD for pure water under hydrodynamic conditions (blue), for a solution containing $3.7 \mathrm{wt} \% \mathrm{CO}_{2}$ (orange) and the interpreted natural state temperature in the well (red; information from MRP, 2013). Data marked with * from Christenson (1987). 
Heating and melting measurements were made on fluid inclusions in quartz and/or calcite samples at four depths in KA23. At room temperature most fluid inclusions were fluid-rich and two phase, with coexisting liquid and vapour bubble. Samples at $262 \mathrm{mRF}$ contained coexisting fluid-rich and vapour-rich inclusions. The summary results of FIA from these samples are compiled in Table 5.3. Representative examples from KA23 of FIA with corresponding CL images are shown in Fig. 5.9. KA23 bivariant plots of $T_{h}$ and $T_{m}$ values and $\mathrm{T}_{\mathrm{h}}$ plotted against vertical depth can be found in Fig. 5.10.

Table 5.3 Fluid inclusion microthermometry results from quartz and bladed calcite samples collected from well KA23 drill cuttings. $\mathrm{T}_{\mathrm{h}}=$ homogenisation temperature; $\mathrm{T}_{\mathrm{m}}=$ final ice melting temperature; $\mathrm{NaCl}$ eq. wt. $\%=$ apparent salinity (Bodnar, 1993); FIA = fluid inclusion assemblage (FIA numbers are arbitrarily assigned and do not reflect paragenetic sequence); $\mathrm{p}=$ primary fluid inclusion; $\mathrm{ps}=$ pseudosecondary fluid inclusion and $\mathrm{s}=$ secondary fluid inclusion.

\begin{tabular}{|c|c|c|c|c|c|c|c|c|c|c|c|}
\hline Well & $\begin{array}{l}\text { Depth } \\
\text { mRF }\end{array}$ & Sample & Type & FIA & $\underset{{ }^{\circ} \mathbf{C}}{T_{h} \text { range }}$ & $\mathrm{n}$ & $\underset{{ }^{\circ} \mathrm{C}}{\operatorname{Avg}}$ & $\underset{{ }^{\circ} \mathbf{C}}{\mathbf{T}_{\mathrm{m}} \text { range }}$ & $\mathrm{n}$ & $\underset{{ }^{\circ} \mathrm{C}}{\text { Avg. }}$ & $\begin{array}{c}\mathrm{NaCl} \mathrm{eq} \\
\text { (wt. \%) }\end{array}$ \\
\hline \multirow[t]{12}{*}{ KA23 } & 262 & Quartz & s & FIA1 & 220 to 232 & 3 & 224 & -0.1 & 3 & -0.1 & 0.2 \\
\hline & & & s & FIA4 & 215 to 242 & 4 & 220 & -0.3 & 4 & -0.3 & 0.5 \\
\hline & & total & s & FIA1, 4 & 215 to 242 & 7 & 222 & -0.1 to -0.3 & 7 & -0.2 & 0.2 to 0.5 \\
\hline & & & s & FIA2 & 202 to 217 & 6 & 212 & -0.1 to -0.4 & 6 & -0.2 & 0.2 to 0.7 \\
\hline & & & s & FIA3 & 205 to 227 & 4 & 212 & -0.2 & 4 & -0.2 & 0.4 \\
\hline & & total & $\mathrm{s}$ & FIA2, 3 & 202 to 227 & 10 & 212 & -0.1 to -0.4 & 10 & -0.2 & 0.2 to 0.7 \\
\hline & & & $\mathrm{s}$ & FIA5 & 241 to 276 & 3 & 253 & -0.1 & 3 & -0.1 & 0.2 \\
\hline & & & $\mathrm{s}$ & FIA6 & 232 to 277 & 6 & 255 & -0.1 & 6 & -0.1 & 0.2 \\
\hline & & total & $\mathrm{s}$ & FIA5, 6 & 232 to 277 & 9 & 254 & -0.1 & 10 & -0.1 & 0.2 \\
\hline & & & s & FIA7 & 202 to 205 & 3 & 204 & -0.1 & 3 & -0.1 & 0.2 \\
\hline & & & s & FIA8 & 225 to 238 & 4 & 231 & -0.1 & 4 & -0.1 & 0.2 \\
\hline & & & $\mathrm{s}$ & FIA9 & 228 to 255 & 3 & 238 & -0.1 & 3 & -0.1 & 0.2 \\
\hline
\end{tabular}

Comments: This crystal has a mix of liquid/vapour ratios.

\begin{tabular}{|c|c|c|c|c|c|c|c|c|c|c|c|}
\hline \multirow[t]{4}{*}{ KA23 } & 262 & Calcite & $\mathrm{p}$ & FIA1 & 212 to 215 & 4 & 213 & -0.2 & 4 & -0.2 & 0.4 \\
\hline & & & $\mathrm{p}$ & FIA2 & 262 to 280 & 5 & 274 & -0.1 to -0.2 & 5 & -0.2 & 0.2 to 0.4 \\
\hline & & & $\mathrm{p}$ & FIA4 & 185 to 218 & 5 & 197 & -0.1 & 5 & -0.1 & 0.2 \\
\hline & & & $\mathrm{p}$ & FIA5 & 212 to 220 & 6 & 216 & -0.1 to -0.2 & 6 & -0.1 & 0.2 to 0.4 \\
\hline \multirow[t]{4}{*}{ KA23 } & 384 & Calcite & $\mathrm{p}$ & FIA1 & 218 to 221 & 6 & 219 & -0.3 & 6 & -0.3 & 0.5 \\
\hline & & & $\mathrm{p}$ & FIA2 & 216 to 226 & 7 & 220 & -0.3 & 7 & -0.3 & 0.5 \\
\hline & & & $\mathrm{p}$ & FIA3 & 220 to 230 & 13 & 224 & -0.3 to -0.4 & 13 & -0.3 & 0.5 to 0.7 \\
\hline & & & $\mathrm{p}$ & FIA4 & 228 to 237 & 12 & 229 & -0.3 & 12 & -0.3 & 0.5 \\
\hline \multirow{3}{*}{ KA23 } & & & $\mathrm{s}$ & FIA2 & 195 to 218 & 9 & 202 & -0.6 to -0.7 & 9 & -0.6 & 1.0 to 1.2 \\
\hline & & & s & FIA3 & 215 to 230 & 8 & 219 & -0.6 to -0.9 & 8 & -0.7 & 1.0 to 1.6 \\
\hline & & & s & FIA4 & 225 to 237 & 4 & 230 & -0.5 & 4 & -0.5 & 0.9 \\
\hline
\end{tabular}




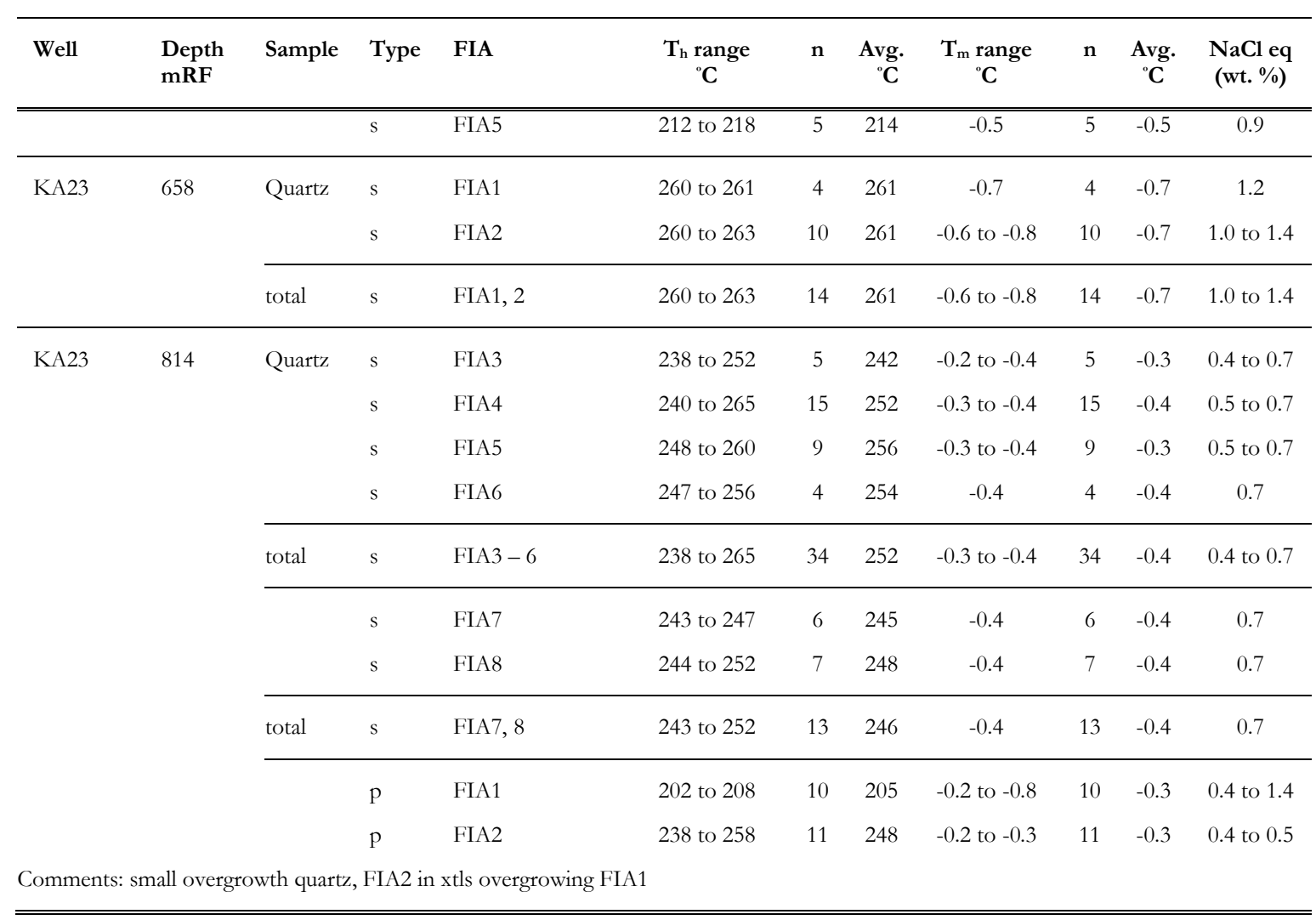




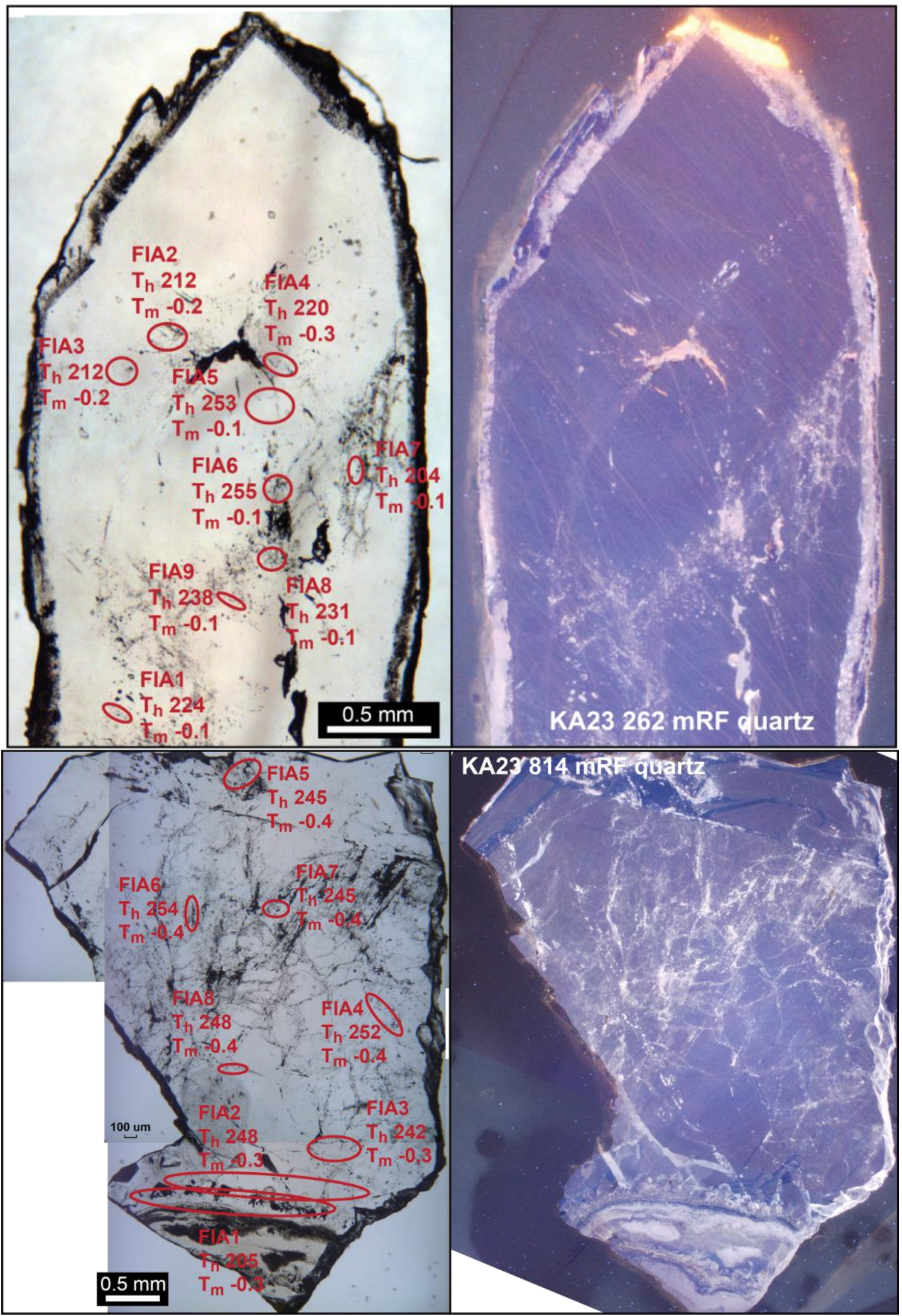

Figure 5.9 Mean homogenisation $\left(\mathrm{T}_{\mathrm{h}}\right)$ and melting $\left(\mathrm{T}_{\mathrm{m}}\right)$ temperatures for FIA in KA23 with corresponding CL image. The sample from $814 \mathrm{mRF}$ shows chalcedony lining a vein margin, followed by 2 generations of drusy quartz and infilled quartz growth. 


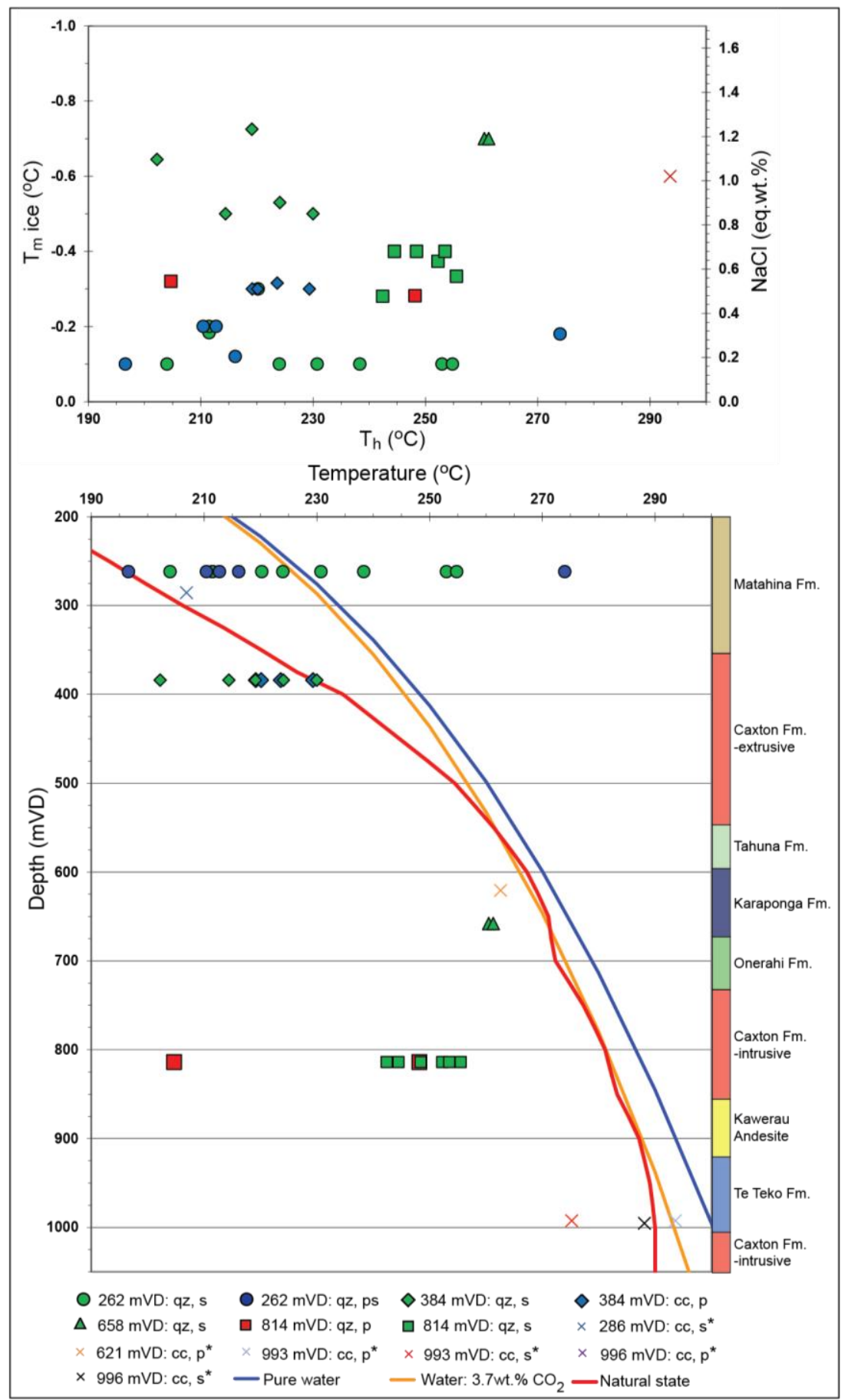

Figure 5.10 Fluid inclusion results from KA23. Each data point represents the mean of a FIA (Table 5.3). Top: Bivariant plot showing measured homogenisation $\left(\mathrm{T}_{\mathrm{h}}\right)$ and melting $\left(\mathrm{T}_{\mathrm{m}}\right)$ temperatures with equivalent salinity (eq. wt. $\% \mathrm{NaCl}$ ). Bottom: Homogenisation temperatures $\left(\mathrm{T}_{\mathrm{h}}\right)$ plotted against vertical depth. The curves represents the BPD for pure water under hydrodynamic conditions (blue), for a solution containing $3.7 \mathrm{wt} . \% \mathrm{CO}_{2}$ (orange) and the interpreted natural state temperature in the well (red; information from MRP, 2013). Data marked with a $*$ in the key from Christenson (1987).

Heating and melting measurements were made on fluid inclusions in quartz and calcite samples from $543 \mathrm{mRF}$ depth in KA26. At room temperature all fluid inclusions were fluidrich and two phase, with coexisting liquid and vapour bubble. The summary results of FIA from these samples are compiled in Table 5.4. KA26 bivariant plots of $T_{h}$ and $T_{m}$ and $T_{h}$ plotted against vertical depth can be found in Fig. 5.11. 
Table 5.4 Fluid inclusion microthermometry results from quartz and bladed calcite samples, collected from well KA26 drill cuttings. $\mathrm{T}_{\mathrm{h}}=$ homogenisation temperature; $\mathrm{T}_{\mathrm{m}}=$ final ice melting temperature; $\mathrm{NaCl}$ eq. wt. $\%=$ apparent salinity (Bodnar, 1993); FIA = fluid inclusion assemblage (FIA numbers are arbitrarily assigned and do not reflect paragenetic sequence); $\mathrm{p}=$ primary fluid inclusion; $\mathrm{ps}=$ pseudosecondary fluid inclusion and $\mathrm{s}=$ secondary fluid inclusion.

\begin{tabular}{|c|c|c|c|c|c|c|c|c|c|c|c|}
\hline Well & $\begin{array}{l}\text { Depth } \\
\text { mRF }\end{array}$ & Sample & Type & FIA & $\underset{{ }^{\circ} \mathrm{C}}{\mathrm{T}_{\mathrm{h}} \text { range }}$ & $\mathrm{n}$ & $\underset{{ }^{\circ} \mathrm{C}}{\text { Avg. }}$ & $\underset{{ }^{\circ} \mathrm{C}}{\mathrm{T}_{\mathrm{m}} \text { range }}$ & $\mathrm{n}$ & $\underset{{ }^{\circ} \mathrm{C}}{\text { Avg. }}$ & $\begin{array}{c}\mathrm{NaCl} \mathrm{eq} \\
\text { (wt. \%) }\end{array}$ \\
\hline \multirow[t]{6}{*}{ KA26 } & 543 & Quartz & s & FIA2 & 220 to 225 & 6 & 222 & -0.6 & 6 & -0.6 & 1 \\
\hline & & & s & FIA3 & 208 to 231 & 6 & 224 & -0.7 to -0.9 & 6 & -0.8 & 1.2 to 1.6 \\
\hline & & total & s & FIA2 -3 & 208 to 231 & 12 & 223 & -0.7 to -0.9 & 12 & -1.0 & 1.2 to 1.6 \\
\hline & & & s & FIA1 & 250 to 252 & 2 & 251 & -0.5 & 2 & -0.5 & 0.9 \\
\hline & & & s & FIA4 & 225 to 248 & 6 & 237 & -0.6 to -0.9 & 6 & -0.8 & 1.0 to 1.6 \\
\hline & 543 & Calcite & $\mathrm{p}$ & total & 240 to 293 & 10 & 270 & -0.2 to -0.8 & 10 & -0.6 & 0.4 to 1.4 \\
\hline
\end{tabular}

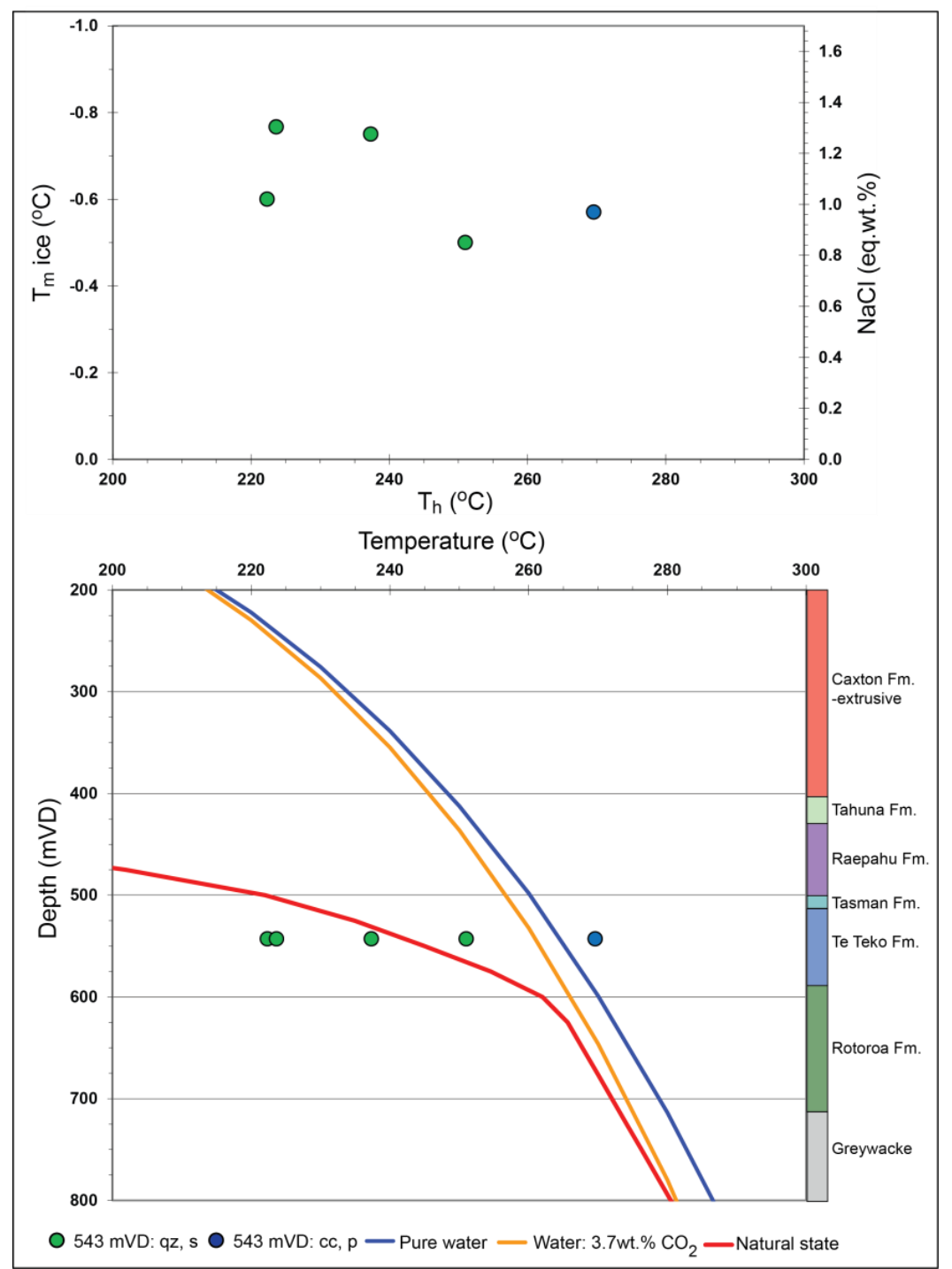

Figure 5.11 Fluid inclusion results from KA26. Each data point represents the mean of a FIA (Table 5.4). Top: Bivariant plot showing measured homogenisation $\left(\mathrm{T}_{\mathrm{h}}\right)$ and melting $\left(\mathrm{T}_{\mathrm{m}}\right)$ temperatures with equivalent salinity (eq. wt. $\% \mathrm{NaCl}$ ). Bottom: Homogenisation temperatures $\left(\mathrm{T}_{\mathrm{h}}\right)$ plotted against vertical depth. The blue curve represents the BPD for pure water under hydrodynamic conditions; the orange curve for a solution containing $3.7 \mathrm{wt} . \% \mathrm{CO}_{2}$ and the red curve the interpreted natural state temperature in the well from MRP (2013). 
Heating and melting measurements were made on secondary fluid inclusions cutting primary quartz at $543 \mathrm{mRF}$ depth in KA28. At room temperature all fluid inclusions were fluid-rich and two phase, with coexisting liquid and vapour bubble. The summary results of FIA from these samples are compiled in Table 5.4. KA28 bivariant plots of $T_{h}$ and $T_{m}$ and $T_{h}$ plotted against vertical depth can be found in Fig. 5.12.

Table 5.5 Fluid inclusion microthermometry results from quartz collected from well KA28 drill cuttings. $\mathrm{T}_{\mathrm{h}}$ $=$ homogenisation temperature; $\mathrm{T}_{\mathrm{m}}=$ final ice melting temperature; $\mathrm{NaCl}$ eq. wt. $\%=$ apparent salinity (Bodnar, 1993); FIA = fluid inclusion assemblage (FIA numbers are arbitrarily assigned and do not reflect paragenetic sequence); $\mathrm{p}=$ primary fluid inclusion; $\mathrm{ps}=$ pseudosecondary fluid inclusion and $\mathrm{s}=$ secondary fluid inclusion.

\begin{tabular}{|c|c|c|c|c|c|c|c|c|c|c|c|}
\hline Well & $\begin{array}{l}\text { Depth } \\
\text { mRF }\end{array}$ & Sample & Type & FIA & $\underset{{ }^{\circ} \mathbf{C}}{\mathbf{T}_{\mathrm{h}} \text { range }}$ & $\mathrm{n}$ & $\underset{{ }^{\circ} \mathrm{C}}{\text { Avg. }}$ & $\underset{{ }^{\circ} \mathbf{C}}{\mathbf{T}_{\mathrm{m}} \text { range }}$ & $\mathrm{n}$ & $\underset{{ }^{\circ} \mathrm{C}}{\text { Avg. }}$ & $\begin{array}{c}\mathrm{NaCl} \text { eq } \\
\text { (wt. \%) }\end{array}$ \\
\hline \multirow[t]{8}{*}{ KA28 } & 656 & Quartz & s & FIA1 & 273 to 278 & 7 & 274 & -0.3 to -0.4 & 7 & -0.4 & 0.5 to 0.7 \\
\hline & & & $\mathrm{s}$ & FIA2 & 272 to 275 & 6 & 274 & -0.4 & 6 & -0.4 & 0.7 \\
\hline & & & $\mathrm{s}$ & FIA3 & 269 to 273 & 11 & 270 & -0.2 to -0.3 & 11 & -0.2 & 0.4 to 0.5 \\
\hline & & & $\mathrm{s}$ & FIA4 & 274 to 276 & 9 & 274 & -0.2 to -0.3 & 9 & -0.2 & 0.4 to 0.5 \\
\hline & & & $\mathrm{s}$ & FIA5 & 274 to 278 & 3 & 276 & -0.2 to -0.3 & 3 & -0.3 & 0.4 to 0.5 \\
\hline & & & $\mathrm{s}$ & FIA6 & 270 to 274 & 10 & 271 & -0.3 & 10 & -0.3 & 0.5 \\
\hline & & total & & FIA1 - 6 & 269 to 278 & 46 & 273 & -0.2 to -0.4 & 46 & -0.3 & 0.4 to 0.7 \\
\hline & & & $\mathrm{s}$ & FIA7 & 235 to 240 & 6 & 238 & -0.4 to -1.3 & 6 & -0.6 & 0.7 to 2.2 \\
\hline
\end{tabular}

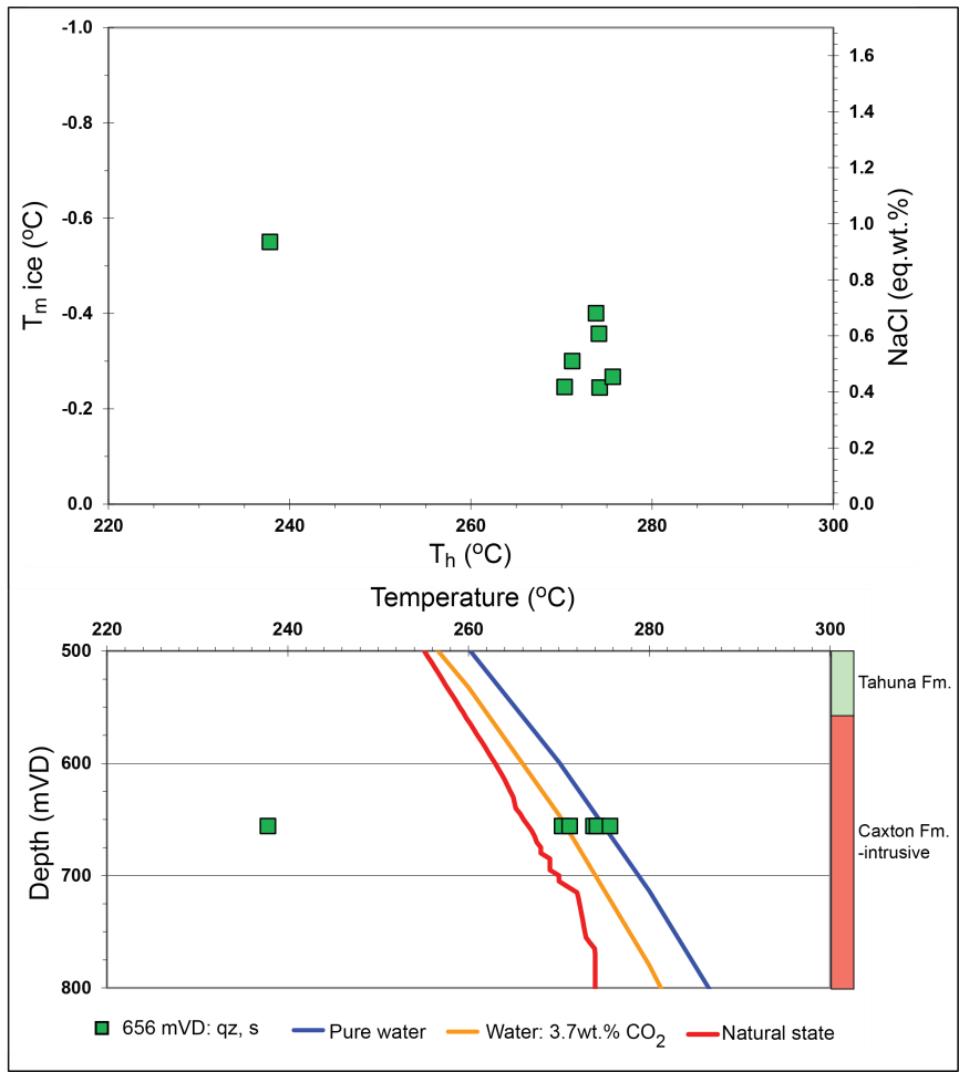

Figure 5.12 Fluid inclusion results from KA28. Each data point represents the mean of a FIA (Table 5.5). Top: Bivariant plot showing measured homogenisation $\left(\mathrm{T}_{\mathrm{h}}\right)$ and melting $\left(\mathrm{T}_{\mathrm{m}}\right)$ temperatures with equivalent salinity (eq. wt. $\% \quad \mathrm{NaCl})$. Bottom: Homogenisation temperatures $\left(T_{h}\right)$ plotted against vertical depth. The curves represents the BPD for pure water under hydrodynamic conditions (blue), for a solution containing 3.7 wt. $\% \mathrm{CO}_{2}$ (orange) and the interpreted natural state temperature in the well (red; information from MRP, 2013). 
Heating and melting measurements were made on vein quartz and bladed calcite samples from $540 \mathrm{mRF}$ depth in KA30. Secondary inclusions cutting primary volcanic quartz at $885 \mathrm{mRF}$, and primary inclusions trapped within calcite formed within a cavity in the primary volcanic quartz were also measured. FIA with corresponding CL images from $885 \mathrm{mRF}$ are shown in Fig. 5.13. At room temperature all fluid inclusions were fluid-rich and two phase, with coexisting liquid and a vapour bubble. The summary results of FIA from these samples are compiled in Table 5.6. KA30 bivariant plots of $\mathrm{T}_{h}$ and $\mathrm{T}_{\mathrm{m}}$ values and $\mathrm{T}_{\mathrm{h}}$ plotted against vertical depth can be found in Fig. 5.14.

Table 5.6 Fluid inclusion microthermometry results from quartz and bladed calcite samples, collected from well KA30 drill cuttings. $\mathrm{T}_{\mathrm{h}}=$ homogenisation temperature; $\mathrm{T}_{\mathrm{m}}=$ final ice melting temperature; $\mathrm{NaCl}$ eq. wt. $\%=$ apparent salinity (Bodnar, 1993); FIA = fluid inclusion assemblage (FIA numbers are arbitrarily assigned and do not reflect paragenetic sequence); $\mathrm{p}=$ primary fluid inclusion; $\mathrm{ps}=$ pseudosecondary fluid inclusion and $\mathrm{s}=$ secondary fluid inclusion.

\begin{tabular}{|c|c|c|c|c|c|c|c|c|c|c|c|}
\hline Well & $\begin{array}{l}\text { Depth } \\
\text { mRF }\end{array}$ & Sample & Type & FIA & $\underset{{ }^{\circ} \mathrm{C}}{\mathbf{T}_{\mathrm{h}} \text { range }}$ & $\mathrm{n}$ & $\underset{\text { Avg. }}{{ }^{\circ} \mathrm{C}}$ & $\begin{array}{c}\mathrm{T}_{\mathrm{m}} \text { range } \\
{ }^{\circ} \mathrm{C}\end{array}$ & $\mathrm{n}$ & $\begin{array}{l}\text { Avg. } \\
{ }^{\circ} \mathrm{C}\end{array}$ & $\begin{array}{c}\mathrm{NaCl} \mathrm{eq} \\
\text { (wt. \%) }\end{array}$ \\
\hline \multirow[t]{6}{*}{ KA30 } & 540 & Quartz & $\mathrm{s}$ & FIA1 & 242 to 265 & 6 & 253 & -0.4 & 6 & -0.4 & 0.7 \\
\hline & & & $\mathrm{s}$ & FIA2 & 248 to 252 & 6 & 252 & -0.3 & 6 & -0.3 & 0.5 \\
\hline & & total & $\mathrm{s}$ & FIA1 - 2 & 242 to 265 & 12 & 252 & -0.3 to -0.4 & 12 & -0.4 & 0.5 to 0.7 \\
\hline & & & $\mathrm{s}$ & FIA3 & 265 to 272 & 8 & 266 & -0.4 & 8 & -0.4 & 0.7 \\
\hline & & & $\mathrm{s}$ & FIA4 & 210 to 220 & 5 & 213 & -0.5 & 5 & -0.5 & 0.9 \\
\hline & & & s & FIA5 & 220 to 238 & 6 & 225 & -0.5 & 6 & -0.5 & 0.9 \\
\hline \multirow[t]{3}{*}{ KA30 } & 540 & Calcite & $\mathrm{p}$ & FIA1 & 198 to 212 & 5 & 202 & -0.2 & 5 & -0.2 & 0.4 \\
\hline & & & $\mathrm{p}$ & FIA2 & 230 to 252 & 6 & 242 & -0.2 & 6 & -0.2 & 0.4 \\
\hline & & & $\mathrm{p}$ & FIA3 & 270 to 292 & 4 & 281 & -0.2 & 4 & -0.2 & 0.4 \\
\hline
\end{tabular}

Comments: difficult to differentiate assemblages, so grouped by temperature.

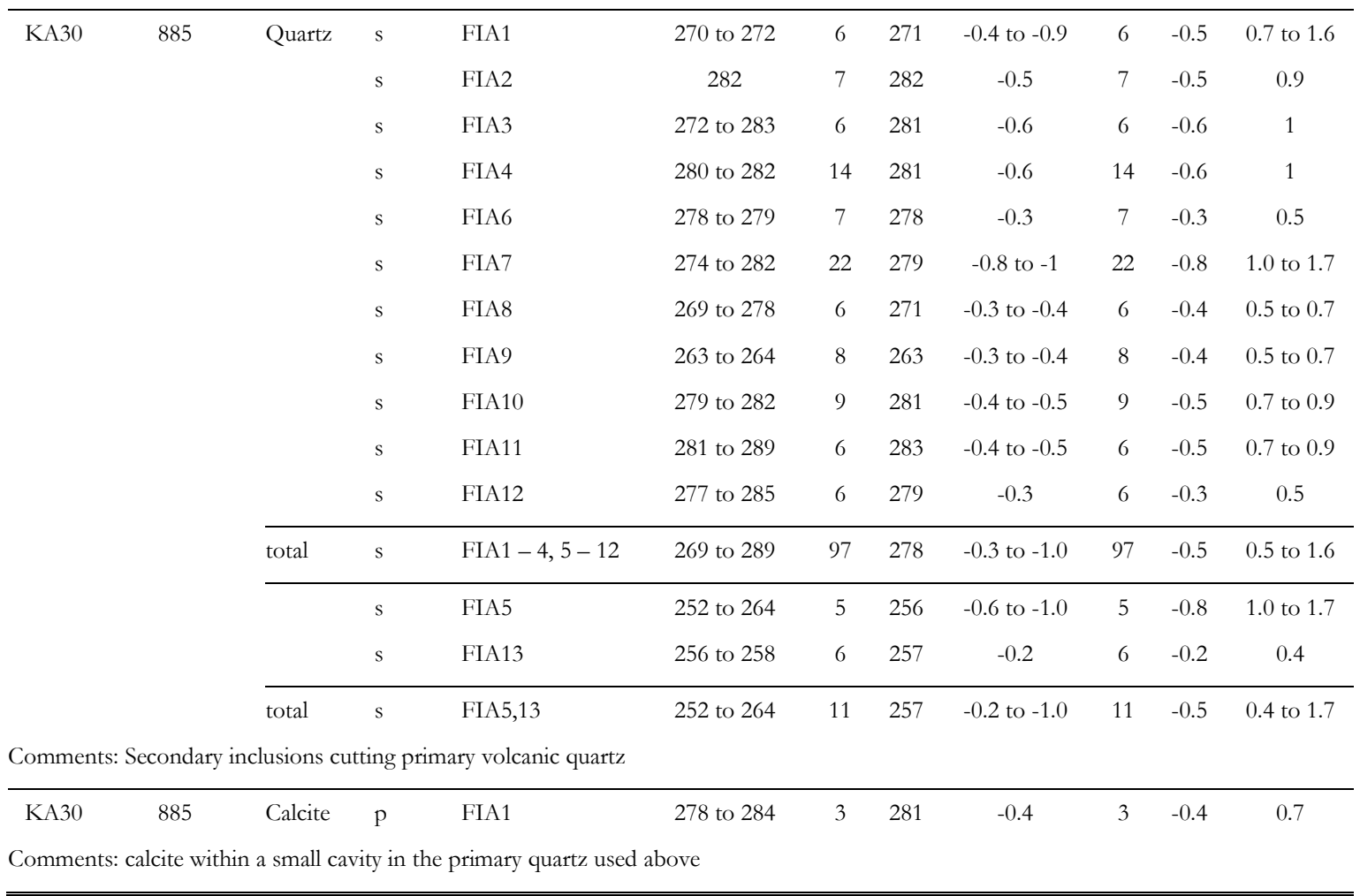




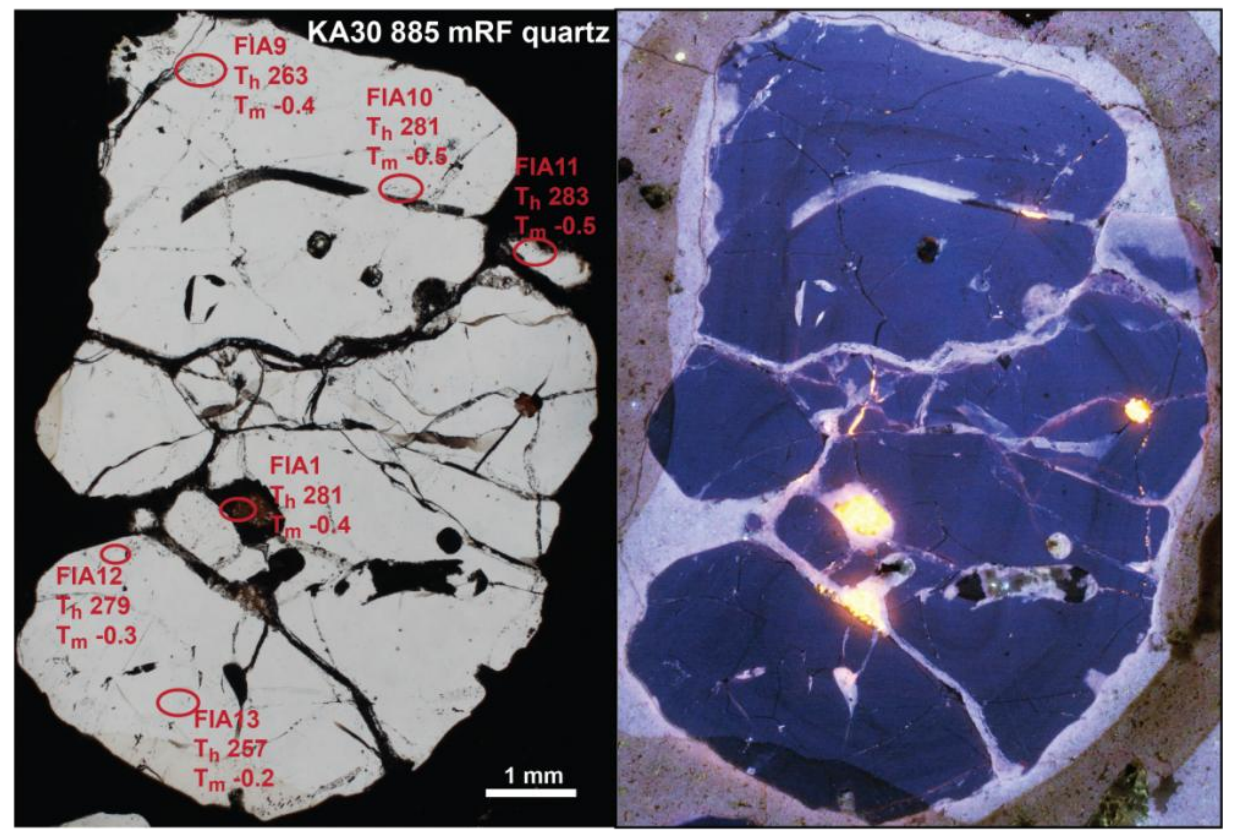

Figure 5.13 Mean homogenisation $\left(\mathrm{T}_{\mathrm{h}}\right)$ and melting $\left(\mathrm{T}_{\mathrm{m}}\right)$ temperatures for FIA at $885 \mathrm{mRF}$ in KA30 with corresponding CL image. FIA1 is of calcite precipitated within a cavity in the quartz crystal.

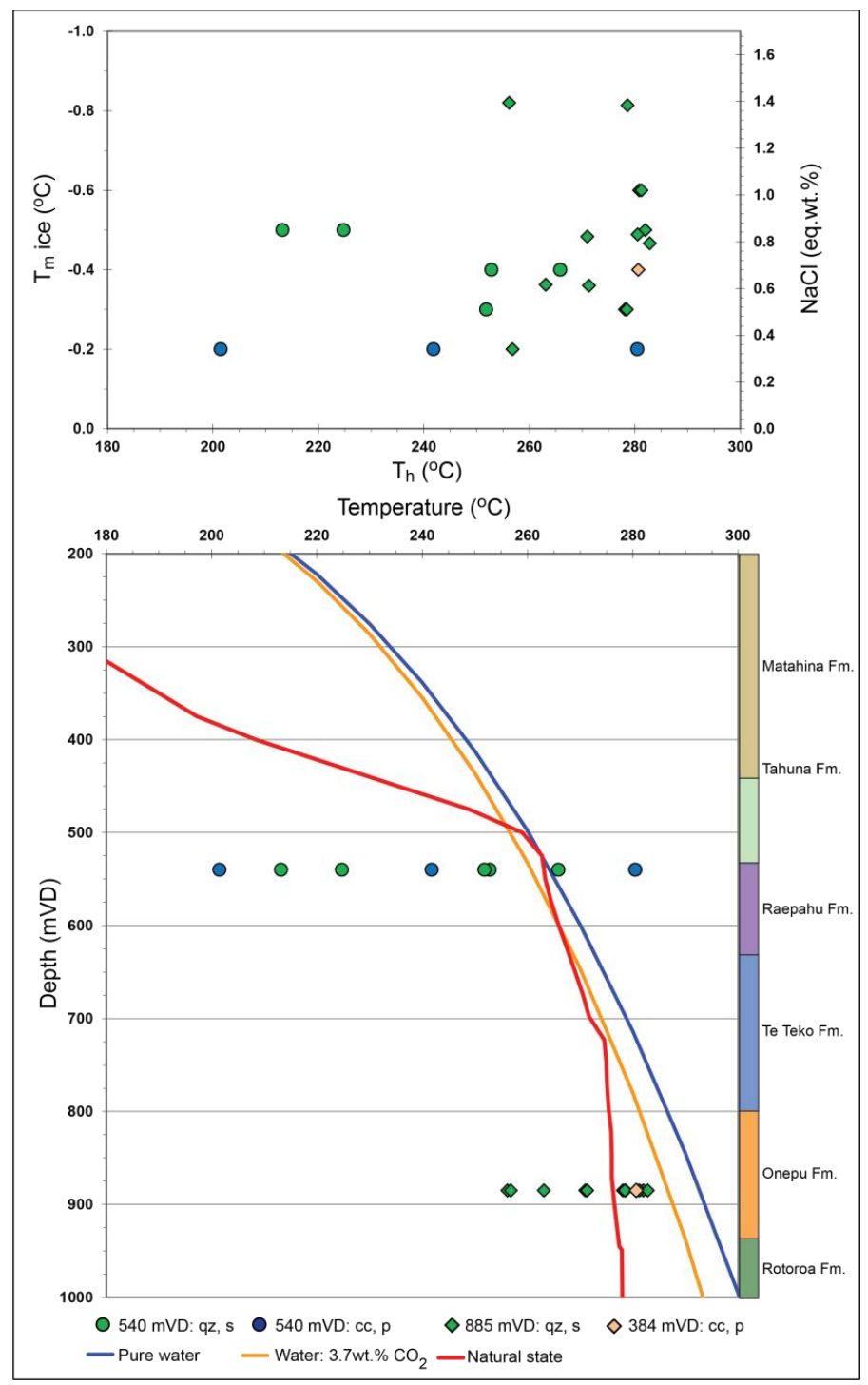

Figure 5.14 Fluid inclusion results from KA30. Each data point represents the mean of a FIA found in Table 5.6. Top: Bivariant plot showing measured homogenisation $\left(\mathrm{T}_{\mathrm{h}}\right)$ and melting $\left(\mathrm{T}_{\mathrm{m}}\right)$ temperatures with equivalent salinity (eq. wt. \% $\mathrm{NaCl}$ ). Bottom: Homogenisation temperatures $\left(\mathrm{T}_{\mathrm{h}}\right)$ plotted against vertical depth. The curves represents the BPD for pure water under hydrodynamic conditions (blue), for a solution containing $3.7 \quad$ wt. $\% \quad \mathrm{CO}_{2}$ (orange) and the interpreted natural state temperature in the well (red; information from MRP, 2013). 
Heating and melting measurements were made on quartz sample from two depths in KA47. At room temperature all fluid inclusions were fluid-rich and two phase, with coexisting liquid and vapour bubble. The summary results of FIA from these samples are compiled in Table 5.7. FIA with corresponding CL image are shown in Fig. 5.15. KA47 bivariant plots of $\mathrm{T}_{\mathrm{h}}$ and $\mathrm{T}_{\mathrm{m}}$ and $\mathrm{T}_{\mathrm{h}}$ plotted against vertical depth can be found in Fig. 5.16.

Table 5.7 Fluid inclusion microthermometry results from quartz samples, collected from well KA47 drill cuttings. $\mathrm{T}_{\mathrm{h}}=$ homogenisation temperature; $\mathrm{T}_{\mathrm{m}}=$ final ice melting temperature; $\mathrm{NaCl}$ eq. wt. $\%=$ apparent salinity (Bodnar, 1993); FIA = fluid inclusion assemblage (FIA numbers are arbitrarily assigned and do not reflect paragenetic sequence); $\mathrm{p}=$ primary fluid inclusion; $\mathrm{ps}=$ pseudosecondary fluid inclusion and $\mathrm{s}=$ secondary fluid inclusion.

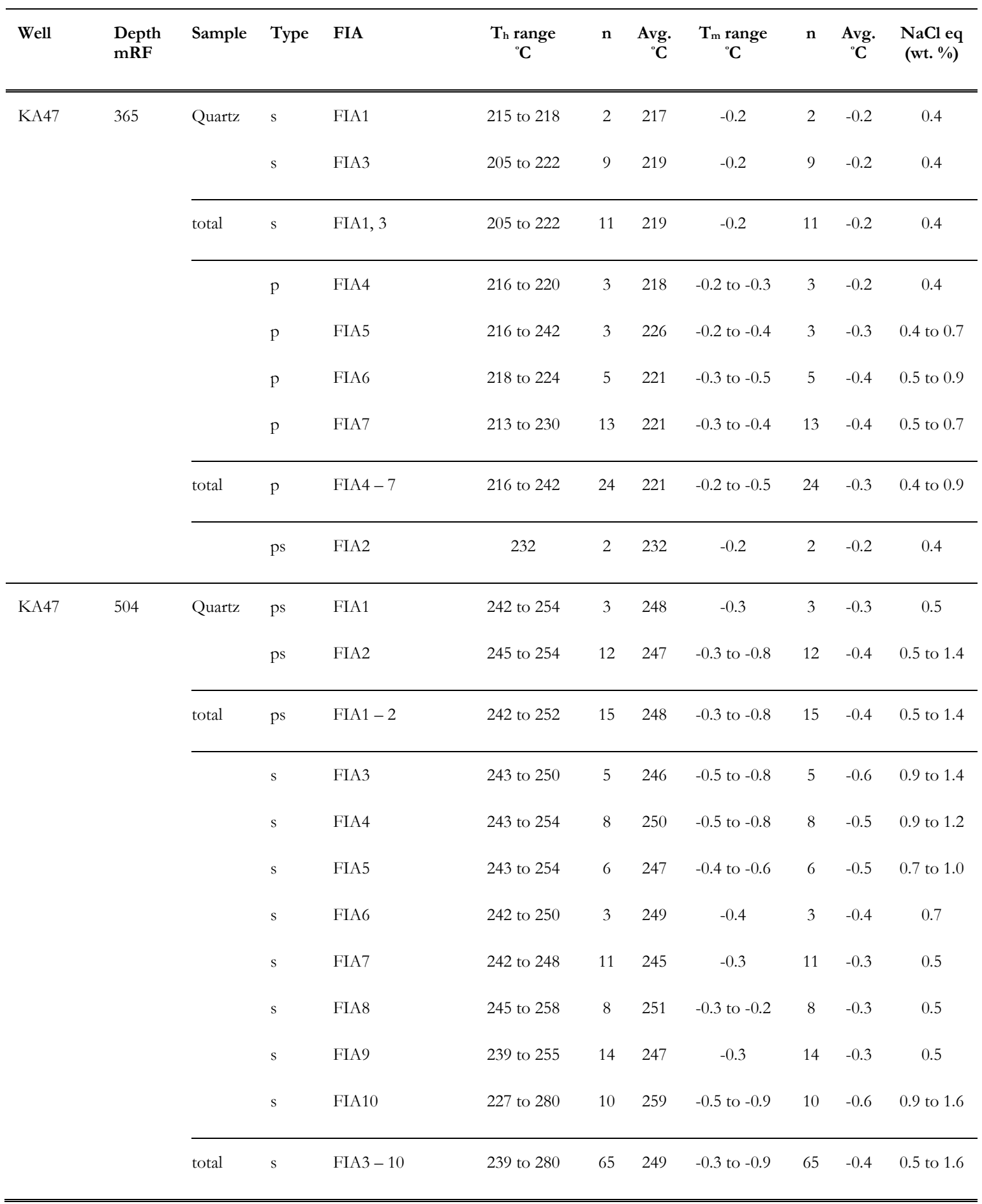



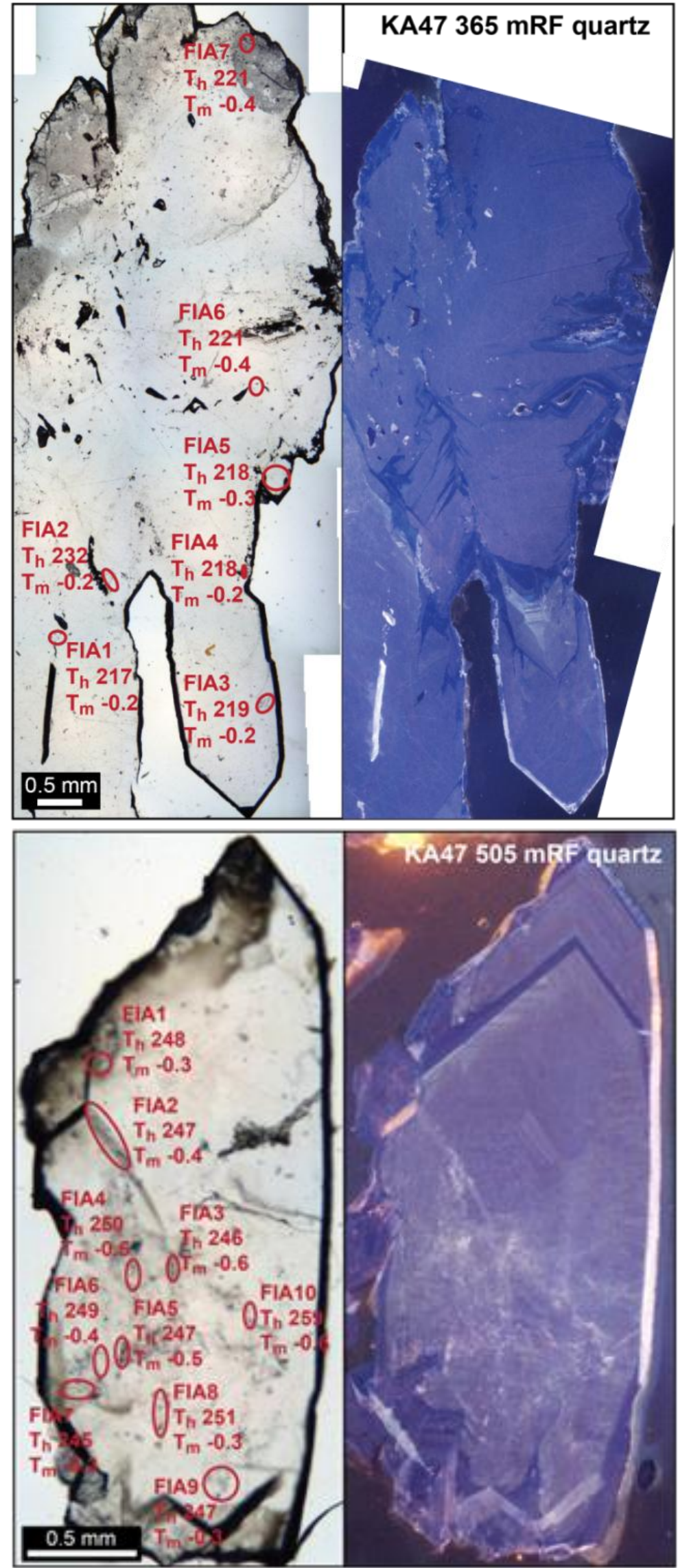

Figure 5.15 Mean homogenisation $\left(\mathrm{T}_{\mathrm{h}}\right)$ and melting $\left(\mathrm{T}_{\mathrm{m}}\right)$ temperatures for FIA in KA47 with corresponding CL image. 


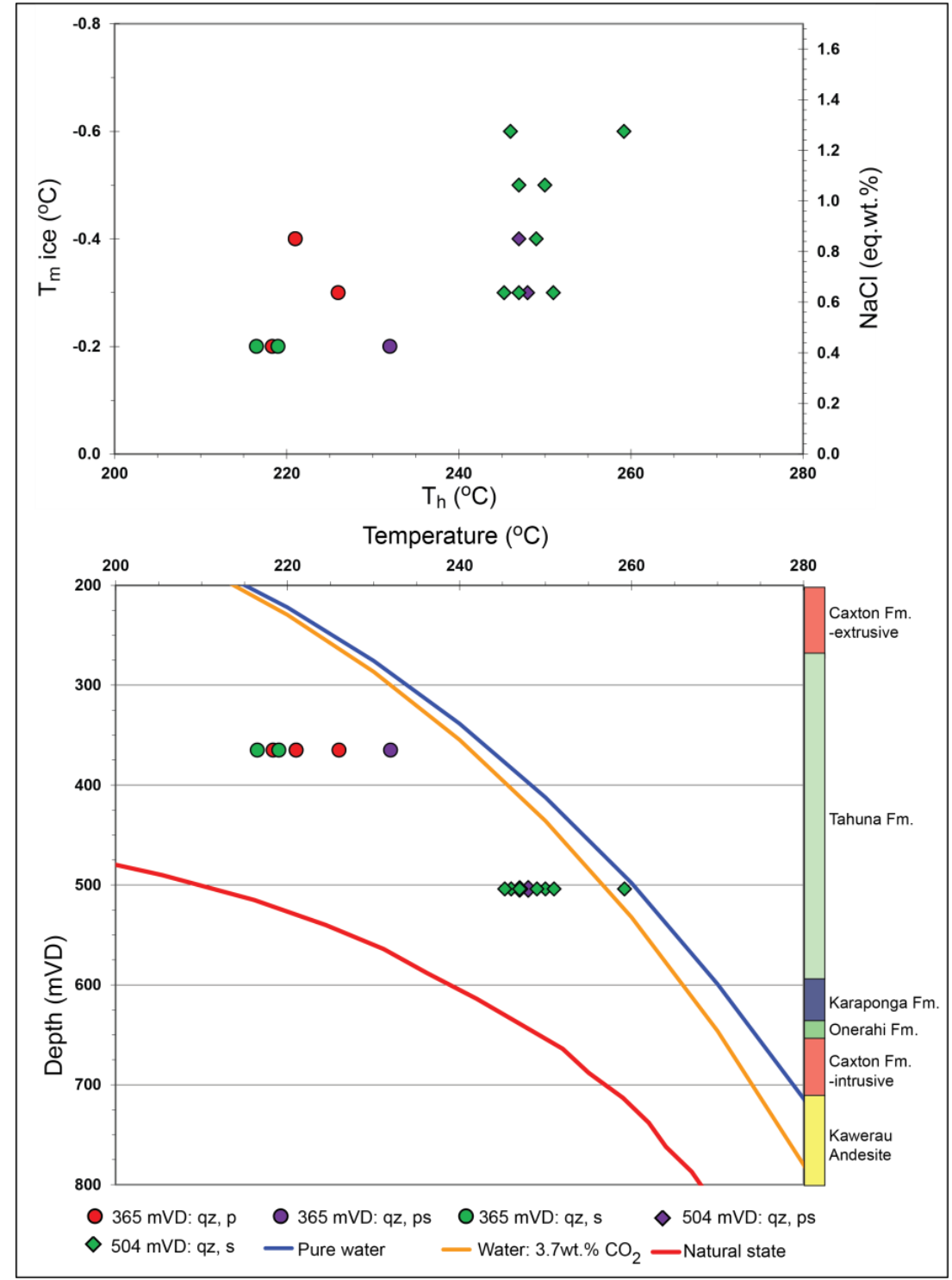

Figure 5.16 Fluid inclusion results from KA47. Each data point represents the mean of a FIA found in Table 5.7. Top: Bivariant plot showing measured homogenisation $\left(T_{h}\right)$ and melting $\left(T_{m}\right)$ temperatures with equivalent salinity (eq. wt. $\% \mathrm{NaCl}$ ). Bottom: Homogenisation temperatures $\left(\mathrm{T}_{\mathrm{h}}\right.$ ) plotted against vertical depth. The curves represents the BPD for pure water under hydrodynamic conditions (blue), for a solution containing $3.7 \mathrm{wt} . \% \mathrm{CO}_{2}$ (orange) and the interpreted natural state temperature in the well (red; information from MRP, 2013).

Heating and melting measurements were made on quartz sample from three depths in KA48. At room temperature all fluid inclusions were fluid-rich and two phase, with coexisting liquid and vapour bubble. The summary results of FIA from these samples are compiled in Table 5.8. KA47 bivariant plots of $\mathrm{T}_{\mathrm{h}}$ and $\mathrm{T}_{\mathrm{m}}$ values and $\mathrm{T}_{\mathrm{h}}$ plotted against vertical depth can be found in Fig. 5.17. 
Table 5.8 Fluid inclusion microthermometry results from quartz and bladed calcite samples collected from well KA48 drill cuttings. $T_{h}=$ homogenisation temperature; $T_{m}=$ final ice melting temperature; $\mathrm{NaCl}$ eq. wt. $\%=$ apparent salinity (Bodnar, 1993); FIA = fluid inclusion assemblage (FIA numbers are arbitrarily assigned and do not reflect paragenetic sequence); $\mathrm{p}=$ primary fluid inclusion; $\mathrm{ps}=$ pseudosecondary fluid inclusion and $\mathrm{s}=$ secondary fluid inclusion.

\begin{tabular}{|c|c|c|c|c|c|c|c|c|c|c|c|}
\hline Well & $\begin{array}{l}\text { Depth } \\
\text { mRF }\end{array}$ & Sample & Type & FIA & $\mathrm{T}_{\mathrm{h}} \underset{{ }^{\circ} \mathbf{C} \mathrm{C}}{ }$ & n & $\underset{{ }^{\circ} \mathrm{C}}{\mathrm{Avg}}$ & $\mathbf{T}_{\mathrm{m}}$ range & $\mathrm{n}$ & $\underset{{ }^{\circ} \mathrm{C}}{\text { Avg. }}$ & $\begin{array}{c}\mathrm{NaCl} \text { eq } \\
\text { (wt. \%) }\end{array}$ \\
\hline \multirow[t]{7}{*}{ KA48 } & 520 & Calcite & ps & FIA2 & 237 to 257 & 4 & 252 & -0.8 to -0.9 & 4 & -0.8 & 1.2 to 1.6 \\
\hline & & & ps & FIA3 & 240 to 262 & 5 & 252 & -0.6 & 5 & -0.6 & 1 \\
\hline & & total & ps & FIA2 -3 & 237 to 262 & 9 & 252 & -0.6 to -0.9 & 9 & -0.6 & 1 to 1.6 \\
\hline & & & $\mathrm{p}$ & FIA4 & 180 to 210 & 5 & 193 & -0.5 & 5 & -0.5 & 0.9 \\
\hline & & & $\mathrm{p}$ & FIA5 & 178 to 200 & 7 & 186 & -0.6 to -0.8 & 7 & -0.7 & 1.0 to 1.4 \\
\hline & & total & $\mathrm{p}$ & FIA4 - 5 & 178 to 210 & 12 & 189 & -0.5 to -0.8 & 12 & -0.6 & 0.9 to 1.4 \\
\hline & & & $\mathrm{p}$ & FIA1 & 208 to 222 & 5 & 216 & -0.7 to -0.9 & 5 & -0.8 & 1.2 to 1.6 \\
\hline \multirow[t]{3}{*}{ KA48 } & 775 & Quartz & $\mathrm{p}$ & FIA1 & 235 to 240 & 6 & 237 & -0.6 to -0.9 & 6 & -0.7 & 1.0 to 1.6 \\
\hline & & & ps & FIA2 & 237 to 240 & 5 & 238 & -0.6 & 5 & -0.6 & 1 \\
\hline & & & $\mathrm{s}$ & FIA3 & 183 to 211 & 4 & 198 & -0.8 & 4 & -0.8 & 1.4 \\
\hline \multirow[t]{4}{*}{ KA48 } & 840 & Calcite & s & FIA1 & 275 to 284 & 8 & 278 & -0.3 to -0.4 & 8 & -0.4 & 0.5 to 0.7 \\
\hline & & & $\mathrm{s}$ & FIA2 & 275 to 289 & 4 & 283 & -0.3 to -0.4 & 4 & -0.4 & 0.5 to 0.7 \\
\hline & & total & $\mathrm{s}$ & FIA1 - 2 & 275 to 289 & 12 & 280 & -0.3 to -0.4 & 12 & -0.4 & 0.5 to 0.7 \\
\hline & & & ps & FIA3 & 342 to 354 & 7 & 346 & -0.3 to -0.4 & 7 & -0.3 & 0.5 to 0.7 \\
\hline KA48 & 840 & Quartz & $?$ & FIA1 & 370 to 382 & 11 & 378 & -0.5 to -0.8 & 11 & -0.6 & 0.9 to 1.4 \\
\hline
\end{tabular}




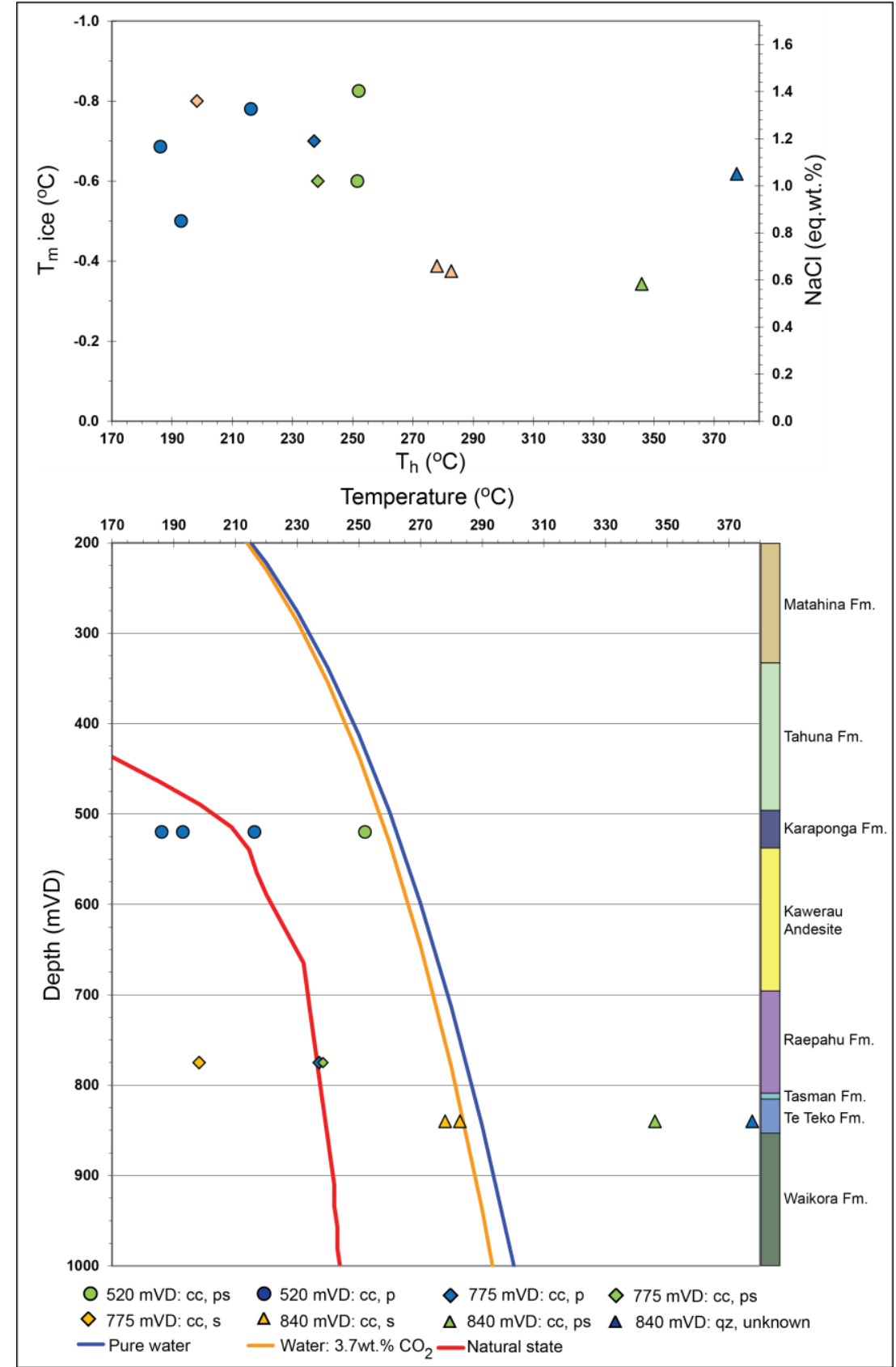

Figure 5.17 Fluid inclusion results from KA48. Each data point represents the mean of a FIA found in Table 5.8. Top: Bivariant plot showing measured homogenisation $\left(T_{h}\right)$ and melting $\left(T_{m}\right)$ temperatures with equivalent salinity (eq. wt. $\% \mathrm{NaCl}$ ). Bottom: Homogenisation temperatures $\left(\mathrm{T}_{\mathrm{h}}\right.$ ) plotted against vertical depth. The curves represents the BPD for pure water under hydrodynamic conditions (blue), for a solution containing $3.7 \mathrm{wt} . \% \mathrm{CO}_{2}$ (orange) and the interpreted natural state temperature in the well (red; information from MRP, 2013).

\subsubsection{Stable isotopes}

Stable isotope analyses are commonly applied to the study of active and fossil geothermal systems and are useful for determining the origins of hydrothermal fluid components, temperatures of mineralisation, as an aid in interpretation of the geothermal system's thermal evolution and longevity (i.e. Craig, 1963; Blattner, 1975; Clayton and Steiner, 1975; McKibbin 
et al., 1986; Ohmoto, 1986; Petrucci et al., 1993; Blattner et al., 1994; Campbell and Larson, 1998).

Stable isotopes are useful in the geothermal setting, because they fractionate and the degree of this fractionation generally varies as a function of temperature (Urey, 1947). This allows the temperature of isotopic equilibration to be calculated. Alternatively, if the equilibrium temperature is known (e.g., from fluid inclusions or down hole temperatures), the isotopic value of the hydrothermal fluid from which a mineral phase was precipitated can be calculated (which can be compared with isotopic values of the modern aquifer).

An important characteristic of oxygen isotope geochemistry in geothermal systems is that of 'oxygen isotope shift' with respect to the local meteoric water (Craig, 1963). Surface waters have a $\delta \mathrm{D}$ and $\delta^{18} \mathrm{O}$ values on or near the Global Meteoric Water Line (GMWL), which approximates the straight line equation of (Craig, 1961):

$$
\delta \mathrm{D}=8 \delta^{18} \mathrm{O} \%+10
$$

Geothermal fluids often plot to the right of the MWL as a result of 'oxygen isotope shift' (Fig. 5.18), caused by the interaction between water and ${ }^{18} \mathrm{O}-$ enriched formation rock. The magnitude of the oxygen isotope shift depends on the original $\delta^{18} \mathrm{O}$ for the water and rock, the mineralogy and texture of the rock, the temperature, the water/rock ratio and the time of contact (Truesdell and Hulston, 1980). The shift increases with a higher degree of water-rock interaction which can often be related to the permeability of the rock (Henley et al., 1984). Hydrogen in contrast is relatively lacking in formation rocks compared to the circulating waters, so $\delta \mathrm{D}$ values in the fluid are little affected by prolonged water-rock interaction (Henley et al., 1984). 


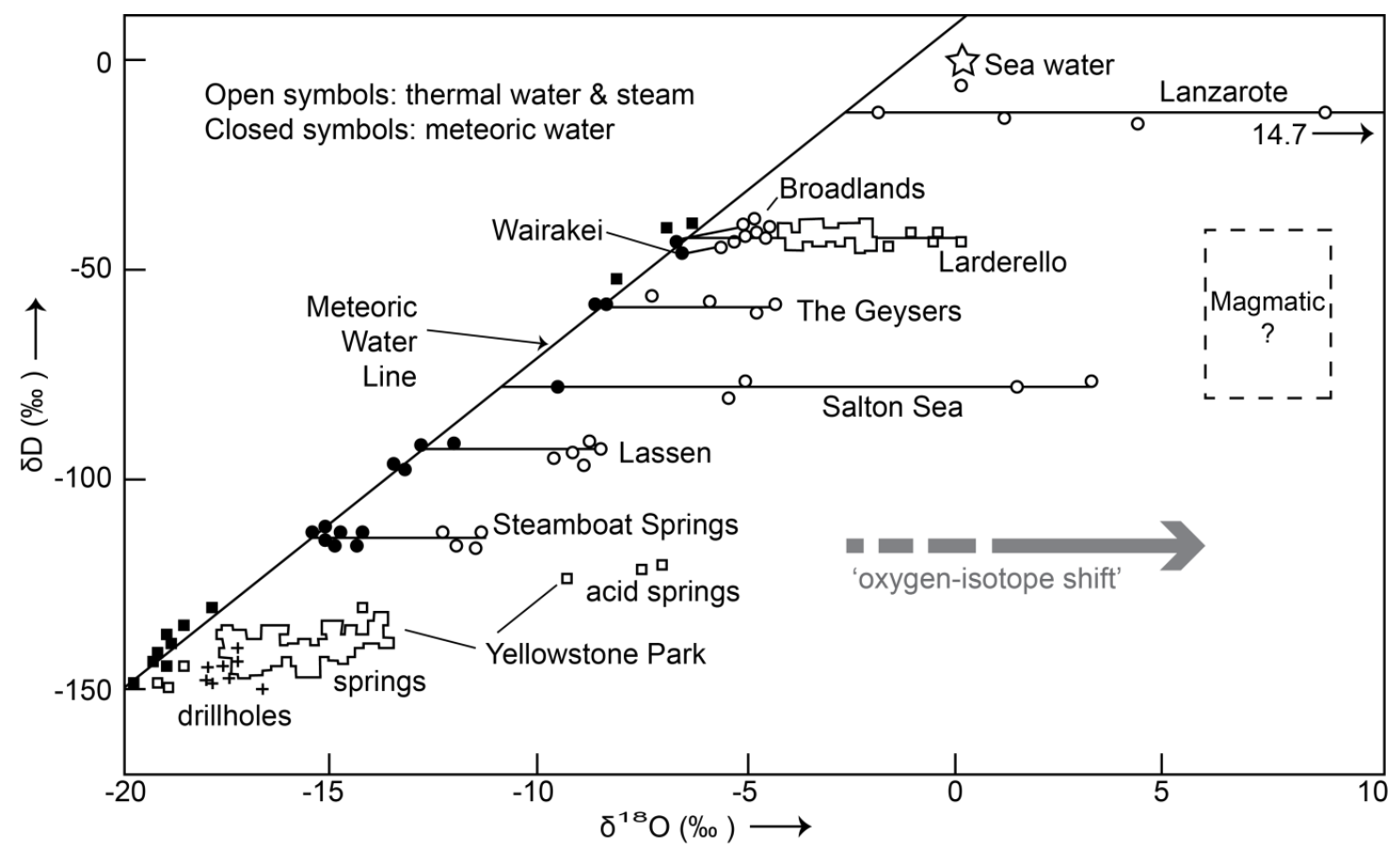

Figure $5.18 \delta \mathrm{O}^{18}$ and $\delta \mathrm{D}$ values of hot-spring, fumarole and drillhole fluids derived from meteoric water (open symbols) and of meteoric water local to each system (closed symbols) (Truesdell and Hulston, 1980). This demonstrates the "oxygen-isotope shift" to the right as a result of waterrock interaction.

An isotope value of a rock/mineral or water is reported in \%o (per mil) in the delta $(\delta)$ notation.

$$
\delta_{\mathrm{A}}=\left(\mathrm{R}_{\mathrm{A}} / \mathrm{R}_{\mathrm{Std}}-1\right) \times 10^{3}
$$

where $\mathbf{R}_{\mathbf{A}}$ is the isotope mass ratio (i.e., for oxygen $\mathrm{O}^{18} / \mathrm{O}^{16}$ ) of sample $\mathbf{A}$ and $\mathbf{R}_{\mathrm{Std}}$ is the same ratio in a standard (e.g., Vienna Standard Mean Ocean Water, VSMOW). The $\delta$ value for VSMOW is therefore zero \%o.

The temperature variation of isotope fractionation factors for specific exchange reactions assumes that the phases are in isotopic equilibrium and is usually expressed by equations in the following form:

$$
\mathbf{1 0}^{3} \ln \alpha_{\mathbf{a}-\mathbf{b}}=\frac{\mathbf{A} \times \mathbf{1 0}^{6}}{\mathbf{T}^{2}}+\mathbf{B}
$$

It is a convenient approximation that if $\boldsymbol{\alpha}_{\mathrm{a}-\mathrm{b}}<1.0010$, then

$$
10^{3} \ln \alpha_{\mathrm{a}-\mathrm{b}} \approx \delta \mathbf{a}-\delta \mathbf{b} \approx \frac{\mathbf{A} \times 10^{6}}{\mathbf{T}^{2}}+\mathbf{B}
$$

where $\mathbf{a}$ and $\mathbf{b}$ are minerals, phases, species, etc., $\mathbf{A}$ and $\mathbf{B}$ are constants and $\mathbf{T}$ is temperature in degrees Kelvin $\left(={ }^{\circ} \mathrm{C}+273.15\right)$. 
Mineral isotope values can be used to estimate the different fluid sources that may have contributed to their compositions by utilising the temperature-dependent equilibrium fractionation between mineral species and fluids. The isotopic value of a fluid can then be calculated, assuming equilibrium fractionation between a mineral and fluid (e.g. $\mathrm{H}_{2} \mathrm{O}, \mathrm{CO}_{2}$ ), if the temperature of crystallisation is known or generally inferred. This provides insight into the physical processes (such as boiling, mixing) affecting the reservoir at the time of mineralisation

Hydrothermal minerals can contain a long-term record of geothermal fluid sources and conditions, albeit complicated by the fact that different minerals may have grown at different times and may have exchanged oxygen isotopic compositions with host solutions at different rates (Blattner, 1975). Clayton and Steiner (1975) found in hydrothermally altered rocks of the Wairakei geothermal system that geothermal quartz had grown in equilibrium with the solution. Complete isotopic exchange between calcite and its host solution in the laboratory was reported by O'Neil et al. (1969), and they found that isotopic exchange with fluid could continue after the crystal was formed. Blattner (1975) suggested that, in the absence of other evidence, it could be assumed geothermal crystals grow in isotopic equilibrium with solution and that fissure quartz once grown, does not exchange oxygen isotope with solutions, while calcite may continue to do so to some extent.

\subsubsection{Methodology}

Oxygen stable isotopes ratios were measured in quartz vein material, and oxygen and carbon stable isotopes in loose bladed calcite crystals from selected wells at Kawerau (Table 5.1). Stable isotope ratios were measured at the National Isotope Centre (NIC), GNS Science, New Zealand.

\section{Oxygen in quartz}

Oxygen was extracted from sample powders for isotope analyses using a $\mathrm{CO}_{2}-$ laser and $\mathrm{BrF}_{5}$ (Sharp, 1990). Oxygen isotope values are reported in the $\delta^{18} \mathrm{O}$ notation, relative to VSMOW. Samples were normalised to the international quartz standard NBS-28 using a value of +9.6 per mil (\%). Values for four NBS-28 samples analysed with the unknowns had values that varied by less than $0.15 \%$. Samples and standards were heated overnight to $150{ }^{\circ} \mathrm{C}$ prior to loading into the vacuum extraction line. These were then evacuated for approximately six hours. Blank $\mathrm{BrF}_{5}$ runs were done until the yield was less than $0.2 \mu$ moles oxygen. Oxygen yields were recorded and $\mathrm{CO}_{2}$ gas analysed on a Geo20-20 mass spectrometer. Reported values have a precision of $\pm 0.1 \%$. 


\section{Carbonate}

Carbonate samples were analysed on the GVI IsoPrime Carbonate Preparation System at a reaction temperature of $25{ }^{\circ} \mathrm{C}$ for 24 hours and run via dual inlet on the IsoPrime mass spectrometer. All results are reported with respect to Vienna PeeDee Belemnite (VPDB), normalised to the internal standard GNS Marble with reported values of $2.04 \%$ for $\delta^{13} \mathrm{C}$ and $-6.40 \%$ for $\delta^{18} \mathrm{O}$. The external precision for these measurements are better than $0.1 \%$ for $\delta^{13} \mathrm{C}$ and $0.2 \%$ for $\delta^{18} \mathrm{O}$. Reported values have a precision of $0.3 \%$ for ${ }^{18} \mathrm{O}$ and 0.1 for ${ }^{13} \mathrm{C}$ $\%$.

\subsubsection{Stable isotope results}

Stable isotope analyses were undertaken on selected samples at 13 depth intervals within the Kawerau geothermal system. Table 5.9 presents the stable isotopes analyses and Fig. 5.19 the result in graphical form.

Quartz $\delta^{18} \mathrm{O}_{\text {vsmow }}$ values range from 11 to $5.5 \%$. Calcite $\delta^{18} \mathrm{O}_{\text {vsmow }}$ values ranges from 10.8 to $2.3 \%$. Calcite $\delta^{13} \mathrm{C}_{\mathrm{VPDB}}$ values ranges from 2 to $-3.0 \%$.

Table 5.9 Carbon and oxygen stable isotope values for selected Kawerau samples.

\begin{tabular}{|c|c|c|c|c|}
\hline Well & Depth (mRF) & mineral & $\delta^{18} \mathbf{O}_{\text {vsmow }}$ & $\delta^{13} \mathrm{C}_{\mathrm{VPDB}}$ \\
\hline KA21 & 262 & quartz & 8 & \\
\hline KA21 & 475 & quartz & 6.5 & \\
\hline \multirow[t]{2}{*}{ KA21ST } & 765 & quartz & 5.5 & \\
\hline & & calcite & 2.3 & -8.4 \\
\hline \multirow[t]{2}{*}{ KA21 } & 829 & quartz & 6.1 & \\
\hline & & calcite & 3.3 & -7.4 \\
\hline \multirow[t]{2}{*}{ KA23 } & 262 & quartz & 9.6 & \\
\hline & & calcite & 6.7 & -5.8 \\
\hline \multirow[t]{2}{*}{ KA23 } & 348 & quartz & 11 & \\
\hline & & calcite & 5.2 & -6.4 \\
\hline KA26 & 543 & calcite & 9.6 & -7.9 \\
\hline \multirow[t]{2}{*}{ KA30 } & 540 & quartz & 8.3 & \\
\hline & & calcite & 5.7 & -6.0 \\
\hline KA47 & 365 & quartz & 8.2 & \\
\hline KA47 & 505 & quartz & 6.2 & \\
\hline KA48 & 520 & calcite & 5.6 & -6.0 \\
\hline KA48 & 775 & calcite & 10.8 & -3.0 \\
\hline KA48 & 840 & calcite & 3.7 & -7.0 \\
\hline
\end{tabular}



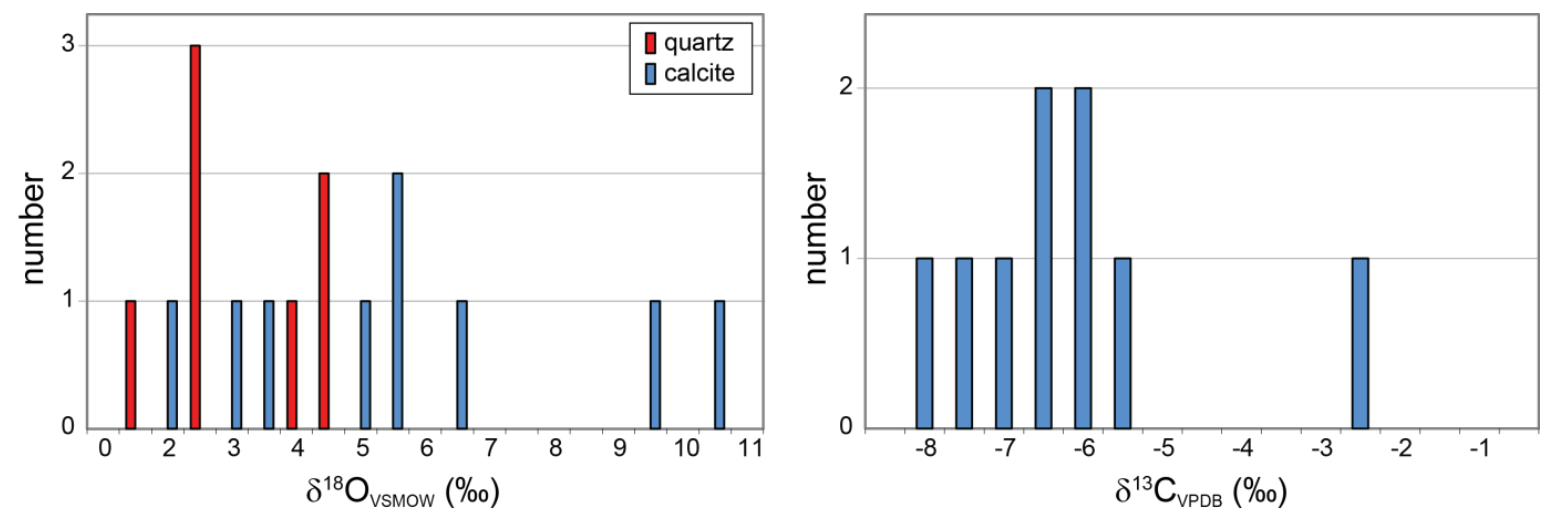

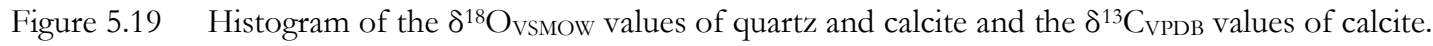

\section{$5.3 \quad$ DISCUSSION}

This study was looking for evidence recorded in hydrothermal mineral on fluid sources and potential input of magmatic derived fluids. It was expected the data would provide insight into the thermal and chemical evolution of the hydrothermal system and potentially provide evidence of distinct 'generations' of system. Using the chronostratigraphic framework developed in Chapters 2 and 3, the generations of system could then be directly related to heat sources associated with the generation and emplacement of rhyolite beneath the field.

\subsubsection{Fluid inclusions}

The geothermal reservoir at Kawerau can be divided into the shallow and deep aquifers, where permeable, formation-hosted aquifers are separated by a discontinuous aquiclude at approximately $400 \mathrm{~m}$ depth (Holt, 2013; Fig. 5.20). This aquiclude is made up of low permeability formations, including fine-grained sediments of the Tahuna Formation and densely welded and/or silicified ignimbrite zones in the Matahina Formation. Permeability within the shallow part of the production area is likely to be associated with enhanced stratigraphic permeability, related to interconnected primary porosity (e.g., within breccia units and non-welded ignimbrite). In contrast, in the deep Kawerau geothermal reservoir, permeability is mainly confined to lithologies that can sustain an extensive, interconnected fracture network, such as the Kawerau Andesite and Caxton Formation. It is useful when looking at the results from fluid inclusion analyses, to consider them in relation to their depth in the system, that is, in the shallow $(<400 \mathrm{~m})$ or deep reservoir $(>400 \mathrm{~m})$, and their position in the system, that is, production upflow or marginal outflow settings. 


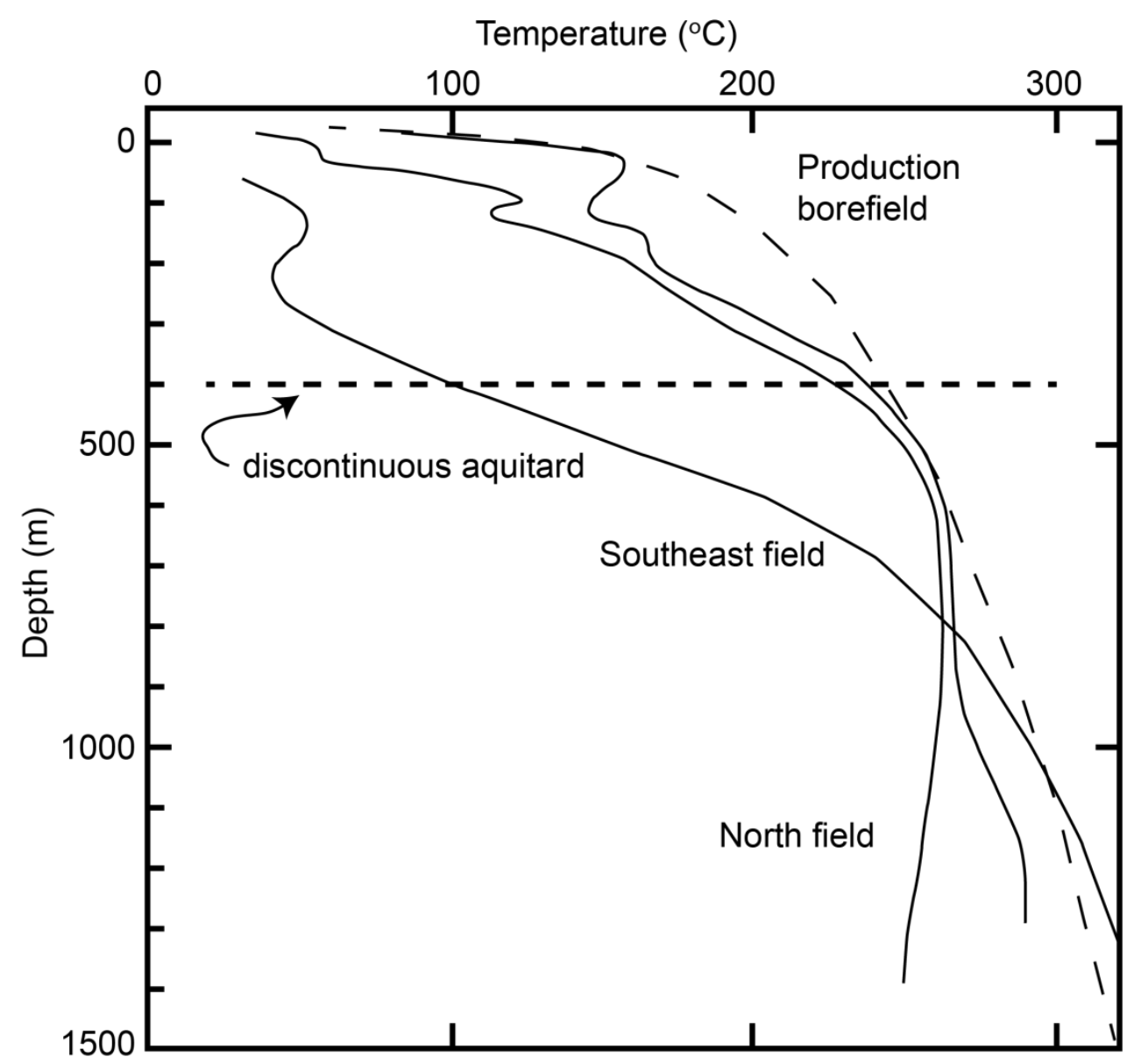

Figure 5.20 Selection of typical temperature profiles from the drilled part of the Kawerau Field; dashed curve is boiling point for depth assuming no gas and hydrostatic pressure (adapted from Allis, 1997).

Geothermal systems typically have measured temperature-pressure profiles reflecting the hydrodynamic conditions (i.e., the hydrostatic pressure due to upflowing hot water; Grant et al., 1982, Hedenquist and Henley, 1985). Boiling occurs in the upflow zone, while on the margins linear thermal profiles are common (due to mixing or low permeability, Hedenquist et al., 1992). Gas pressure can equal the water vapour pressure, and can have the effect of increasing the boiling depth at a particular temperature for respective wells (Hedenquist et al., 1992). In general, thermal profiles in geothermal wells are limited by the BPD curve (Grant et al., 1982) appropriate to the fluid (i.e. salinity and gas content). Due to this limitation, fluids trapped in fluid inclusions often follow the BPD conditions at the time of entrapment.

The temperature profiles plotted in Figs. 5.9, 5.11, 5.12, 5.15, 5.17 and 5.18 are considered to be interpreted natural state temperatures (i.e. the state of the reservoir prior to development for electricity generation: MRP, 2013). Local temperature inversions (Fig. 5.20) occur widely, indicating that aquifers containing cross-flowing cool groundwater are merging with the rising geothermal water. This process is particularly marked at depths $<400 \mathrm{~m}$ and causes well temperature profiles to deviate from the BPD curve. In the south of the field, towards Putauaki volcano, temperatures reach over $315^{\circ} \mathrm{C}$ at depths greater than $1 \mathrm{~km}$ (Fig. 5.20), 
suggesting that the deep heat source for the field lies beneath Putauaki. Downhole chloride concentrations decrease northwards across the main field, confirming the dominance of mixing and dilution with groundwater in an outflow zone extending to $>1 \mathrm{~km}$ depth. In the main production borefield, temperatures are typically in the range $260-290{ }^{\circ} \mathrm{C}$ at production depths (Fig. 5.20), consistent with boiling of $\mathrm{CO}_{2}$-bearing fluids (Christenson, 1997). In the north, a temperature inversion is inferred below about $700 \mathrm{~m}$ depth suggesting an outflow of geothermal water towards the north at around these depths. In the northern borefield, measured temperatures are lower than the boiling point conditions (Fig. 5.20), although the two phase conditions are present in the shallow aquifer. Boiling point for depth conditions are also present in shallow aquifers overlying the production borefield area.

\subsubsection{Shallow reservoir}

The shallow reservoir is influenced by dilution/mixing and near surface boiling processes. Conditions in this zone are likely to have varied widely over time, which is reflected in large scatter in mean $T_{h}$ measurements for FIA. In particular the measurements from a bladed calcite sample at $262 \mathrm{mRF}$ in KA23 (Figs. 5.10, 5.11) show large scatter in FIA mean $\mathrm{T}_{\mathrm{h}}$ values. Coeval liquid-dominated and vapour-dominated fluid inclusions are present in this sample (Fig 5.6b) and indicate entrapment of 2-phase conditions, which could account for the higher $T_{h}$ values for this sample. The presence of vapour-dominated fluid inclusions supports the suggestion that the FIA populations were formed from a boiling solution (Roedder, 1984, Bodnar et al., 1985). This particular sample is from the non-welded basal unit of the Matahina ignimbrite (Fig. 5.9), which is likely to have had a higher permeability than the surrounding fine-grained sediments, facilitating boiling conditions in the pore spaces. Similarly some fluid inclusions from vein quartz at $262 \mathrm{mRF}$ in KA21 (Figs. 5.8, 5.9) were likely trapped in boiling conditions, with some FIA mean $\mathrm{T}_{\mathrm{h}}$ values lying above both the BPD curve for pure water and the interpreted natural state temperature. This sample is from the brecciated top of the Caxton Formation (Fig. 5.9) which, as for the previous described sample, would have had sufficient porosity to facilitate boiling.

\subsubsection{Deep reservoir}

The fluid inclusion data for samples from the deep reservoir generally show little evidence of deviation from current boiling point reservoir conditions. Where disequilibrium between the minerals and fluids is apparent, boiling and/or mixing with marginal waters is likely the cause 
(Reed and Spycher, 1984, Hedenquist and Browne, 1989, Hedenquist, 1990). Focusing on wells in the main production borefield (KA21, Fig. 5.9; KA28, Fig. 5.13; KA47, Fig. 5.17), measured fluid inclusion homogenisation temperatures point to a general thermal stability since the fluid inclusions were formed. Fluid inclusions from vein quartz and bladed calcite in samples from deeper than $684 \mathrm{mRF}$ in KA21 (Fig. 5.9) lie close to, or below, the BPD curve for a 3.7 wt. $\% \mathrm{CO}_{2}$ fluid and interpreted natural state temperature. There is overlap in mean $\mathrm{T}_{\mathrm{h}}$ and $\mathrm{T}_{\mathrm{m}}$ values for FIA of primary, pseudosecondary and secondary origins, meaning temperature conditions were similar when these fluids were trapped. Christenson (1987) suggested that trapped fluids with $\mathrm{T}_{\mathrm{h}}$ values falling close to the BPD curve for pure water represented a fluid that had degassed, due likely to local boiling events. A similar situation also occurs in KA28 at $656 \mathrm{mRF}$ (Fig. 5.13), where mean $\mathrm{T}_{\mathrm{h}}$ of several FIA lie on the BPD for pure water. A contrasting mode of origin and influencing processes is inferred for those FIA where mean $\mathrm{T}_{\mathrm{h}}$ values fall above the BPD curve (i.e. $684 \mathrm{mRF}, \mathrm{KA} 21$; KA26, $543 \mathrm{mRF}$ ). This situation can occur when the fractures in which the fluids are trapped become overpressured (the confining pressure being in excess of hot hydrostatic; Christenson, 1987). Hedenquist and Henley (1985) and Grindley and Browne (1977) noted the necessity for overpressuring as a pre-requisite for initiation of hydraulic fracturing in hydrothermal systems. The depressuring resulting from the hydrofracturing event would also lead to separation of $\mathrm{CO}_{2}$, together with boiling and supersaturation with respect to calcite and quartz (Christenson, 1987). This effect has been documented in the Waiotapu geothermal system (Hedenquist and Browne, 1989) and is inferred to have occurred at Kawerau.

An exception to thermal stability exhibited in the main production borefield is a hightemperature FIA recorded in KA21 at $765 \mathrm{mVD}$ depth in bladed calcite, where the mean $\mathrm{T}_{\mathrm{h}}$ value for the FIA is $326^{\circ} \mathrm{C}$ (Fig. 5.9). This anomalous sample is likely due to a transient perturbation in the system, and clearly does not relate to current conditions. Possibilities for this perturbation could be a fault rupture allowing a pulse of hot, deep fluid, shallower into the reservoir or represent boiling related to the depressurisation. Alternatively the heat pulse could be related to intrusion of either the Caxton or Onepu formations. A similar high-temperature event is recorded in FIA from KA48 at $840 \mathrm{mVD}$ (Fig. 5.18).

Also noted in KA21 at $475 \mathrm{mVD}$ (Fig. 5.9) is evidence of a cooler event. Mean $\mathrm{T}_{\mathrm{h}}$ values from primary FIA in vein quartz at this depth are the same as interpreted natural state temperature, while mean $\mathrm{T}_{\mathrm{h}}$ values from secondary FIA average $45^{\circ} \mathrm{C}$ cooler. Given the general agreement with the current well temperatures, it is inferred here that this cooler event was likely to be transient. This sample is in the fractured lower part of the Caxton Formation, which could facilitate ingress of cool water at this level. This same trend is seen at $540 \mathrm{mVD}$ depth in 
KA30 (Fig. 5.15). This well is on the western margin of the field, and is strongly influenced by inflowing cool water (Holt, 1013).

A deeper example of FIA with $\mathrm{T}_{\mathrm{h}}$ lower than interpreted natural state temperatures is at 814 $\mathrm{mVD}$ in KA23 (Fig. 5.11). The vein quartz at this interval shows growth of chalcedony along the vein margin, followed by two generations of drusy quartz crystals lining the vein wall, then infill with larger quartz crystals (Fig. 5.10), with the sequence showing a heating trend, From the early chalcedony precipitation, temperatures increased to $205^{\circ} \mathrm{C}$ for the first generation of drusy quartz, $248{ }^{\circ} \mathrm{C}$ for the second, to $252{ }^{\circ} \mathrm{C}$ in the large quartz in the centre of the vein. These temperatures are still cooler than the interpreted natural state temperature at this depth at around $280^{\circ} \mathrm{C}$, indicating heating towards current temperatures after the fluid inclusions formed. In the case of quartz, typically a hydrothermal-magmatic event that induces an increase in temperature would result in the dissolution of quartz (Fournier, 1985). Moore et al. (2002) described quartz overgrowth on chalcedony cores have in the Karaha-Telaga Bodas geothermal system at inferred $>250{ }^{\circ} \mathrm{C}$ (higher than the stability of chalcedony of $<190{ }^{\circ} \mathrm{C}$ : White and Hedenquist, 1990). This was inferred to result from depressurisation and boiling of the reservoir liquids. This could be the situation at Kawerau, where the abundance of bladed calcite implies boiling conditions. The lack of dissolution between the early botryoidal form of chalcedony and the later quartz suggest that this depositional sequence represents a single continuous event.

In many of the samples, although measured $T_{h}$ values may have a narrow range, $T_{m}$ values have a large variation. An example of this is at $885 \mathrm{mRF}$ in KA30 (Fig. 5.15). This is a sample of primary volcanic quartz cut by trains of secondary fluid inclusions in healed fractures, along with a pocket of calcite inferred to have precipitated from the same fluids as represented in the secondary quartz fluid inclusions (Fig. 5.14). The mean $T_{h}$ values in secondary FIA for this sample range from 263 to $283{ }^{\circ} \mathrm{C}$, while the mean $\mathrm{T}_{\mathrm{m}}$ values range from -0.3 to $-1.0^{\circ} \mathrm{C}$ which translates to 0.5 to $1.7 \mathrm{wt} . \% \mathrm{NaCl}$ eq. The lower melting temperatures of these fluid inclusions are not necessarily related to higher salinities, but may be accounted for by relative high $\mathrm{CO}_{2}$ in solution (i.e., $>3.5$ wt. $\% \mathrm{CO}_{2}$ : Hedenquist and Henley, 1985). There can also be a reduction in salinity during crystallisation which can be due to degassing during a vigorous boiling event (i.e. decrease in the $\mathrm{CO}_{2}$ in the fluid). Due to these effects, changes in $\mathrm{CO}_{2}$ concentrations can explain much of the apparent variation in salinity data, rather than actual fluctuations in the concentrations of dissolved salts (Hedenquist and Henley, 1985).

Throughout much of the Kawerau Field the presence of bladed calcite, secondary fluid inclusions that plot at or above the BPD curve for pure water and moderate variations in 
apparent salinity, indicate boiling events at various times in the past. Given that all of the data from this study are collected from vein quartz and bladed calcite, it is deduced here that fracture environments have fostered repeated and locally intense boiling events.

Fluid inclusions in the Kawerau system are overwhelmingly dominated by meteoric waters. There is no evidence of a magmatic fluid contribution to the trapped compositions. In porphyry copper deposits it has been shown that early veins within the host rock contain high-temperature (can extend to as high as $1000{ }^{\circ} \mathrm{C}$ ) and high-salinity (>25 wt. $\% \mathrm{NaCl}$ eq, or saturated with daughter minerals) fluids, related to an aqueous phase separating from the cooling pluton. Later veins contain lower temperature $\left(250\right.$ to $\left.350{ }^{\circ} \mathrm{C}\right)$ and low salinity $(<5$ wt.\% $\mathrm{NaCl}$ eq) fluid inclusions, derived from meteoric fluids (Beane and Bodnar, 1995). In general, fluid inclusions related to primary magmatic fluids would be high-salinity (halitebearing) and high-temperature $\left(500-600{ }^{\circ} \mathrm{C}\right.$ : Bodnar, 1995). Bodnar (1995) did note that moderate salinity ( 10 wt. $\% \mathrm{NaCl}$ eq.) and moderate temperature $\left(300-400{ }^{\circ} \mathrm{C}\right)$ liquid-rich fluid inclusions could contain fluid of magmatic origin. The low sulfidation system of the Golden Cross ore deposit had early fluids with very high apparent salinity $(10-23 \mathrm{wt} . \% \mathrm{NaCl}$ eq) that was inferred to be of magmatic origin (DeRonde and Blattner, 1988). In a magmatichydrothermal system that develops around a pluton emplaced at shallow levels, more than 95 $\%$ of all water that flows through the upper region of the pluton is thought to be externally sourced (Norton and Knapp, 1977; Bodnar, 1995). The moderate-temperature (generally $<300{ }^{\circ} \mathrm{C}$ ) and low-salinity (<1.4 wt. $\% \mathrm{NaCl}$ eq.) of the fluid inclusions at Kawerau represents a fluid source dominated by meteoric waters, perturbed by transient, local or short-lived processes that appear to be common to all documented hydrothermal systems of the TVZ (i.e. Ohaaki: Hedenquist, 1990; Waiotapu: Hedenquist and Henley, 1985; Wairakei: Hedenquist and Henley, 1985).

\subsubsection{Stable isotopes}

\subsubsection{Fluid $\delta^{18} \mathrm{O}$ values}

Taking a temperature range $\left( \pm 10{ }^{\circ} \mathrm{C}\right.$ from a primary fluid inclusions, where available, or interpreted natural state well temperature: MRP, 2013) as representative of the thermal conditions of isotopic equilibration, the isotopic values of the fluids in equilibrium with the hydrothermal quartz and calcite have been calculated (Table 5.10 and Table 5.11, Fig. 5.21). 
The oxygen isotope values of the fluid in equilibrium with quartz and calcite (Table 5.10) were calculated using the fractionation factors from Zheng (1993) and O’Neil et al. (1969) respectively. Assuming the interpreted range of temperatures (Table 5.10), the fluid in equilibrium with quartz has oxygen isotope values between -4.3 to $1.8 \%$ and -4.8 to $3.5 \%$ o for calcite.

Table 5.10 $\delta^{18} \mathrm{O}_{\mathrm{H} 2 \mathrm{O}}$ in equilibrium with Kawerau quartz and calcite samples at tabulated temperature ranges.

\begin{tabular}{|c|c|c|c|c|}
\hline Well & $\begin{array}{l}\text { Depth } \\
\text { (mRF) }\end{array}$ & mineral & $\begin{array}{l}\text { Temperature } \\
\text { range }\left({ }^{\circ} \mathrm{C}\right)\end{array}$ & $\delta^{18} \mathbf{O}_{\text {water }}$ \\
\hline KA21 & 262 & quartz & 220 to 240 & -2.5 to -1.5 \\
\hline KA21 & 475 & quartz & 250 to 270 & -2.5 to -1.6 \\
\hline \multirow[t]{2}{*}{ KA21ST } & 765 & quartz & 270 to 290 & -2.6 to -1.9 \\
\hline & & calcite & 270 to 290 & -4.2 to -3.6 \\
\hline \multirow[t]{2}{*}{ KA21 } & 829 & quartz & 270 to 290 & -2.0 to -1.3 \\
\hline & & calcite & 280 to 300 & -2.9 to -2.3 \\
\hline \multirow[t]{2}{*}{$\mathrm{KA} 23$} & 262 & quartz & 190 to 210 & -2.7 to -1.4 \\
\hline & & calcite & 190 to 220 & -3.4 to -1.8 \\
\hline \multirow[t]{2}{*}{ KA23 } & 348 & quartz & 225 to 245 & 0.8 to 1.8 \\
\hline & & calcite & 220 to 240 & -3.3 to -2.5 \\
\hline KA26 & 543 & calcite & 250 to 270 & 2.3 to 3.0 \\
\hline \multirow[t]{2}{*}{ KA30 } & 540 & quartz & 255 to 275 & -0.4 to 0.4 \\
\hline & & calcite & 260 to 280 & -1.2 to -0.5 \\
\hline KA47 & 365 & quartz & 210 to 230 & -2.8 to -1.7 \\
\hline KA47 & 505 & quartz & 220 to 240 & -4.3 to -3.3 \\
\hline KA48 & 520 & calcite & 185 to 220 & -4.8 to -3.0 \\
\hline KA48 & 775 & calcite & 230 to 250 & 2.7 to 3.5 \\
\hline KA48 & 840 & calcite & 230 to 250 & -4.4 to -3.6 \\
\hline
\end{tabular}

The carbon isotope values of the fluid (dissolved $\mathrm{CO}_{2}-\mathrm{H}_{2} \mathrm{CO}_{3}$, Table 5.11) in equilibrium with calcite were calculated using the fractionation factors of Ohmoto and Rye (1979). $\delta^{13} \mathrm{C}_{\mathrm{H} 2 \mathrm{CO} 3}$ values range from -6.8 to $-1.7 \%$ (Table 5.11 ). 
Table $5.11 \quad \delta^{13} \mathrm{C}_{\mathbf{H} 2 \mathrm{CO} 3}$ in equilibrium with Kawerau calcite samples at tabulated temperature ranges.

\begin{tabular}{lllll}
\hline Well & $\begin{array}{l}\text { Depth } \\
(\mathbf{m R F})\end{array}$ & mineral & $\begin{array}{c}\text { Temperature } \\
\text { range }\left({ }^{\circ} \mathbf{C}\right)\end{array}$ & $\boldsymbol{\delta}^{13} \mathbf{C}_{\text {H2CO2 }}$ \\
\hline \hline KA21ST & 765 & calcite & 270 to 290 & -6.8 to -6.5 \\
KA21 & 829 & calcite & 280 to 300 & -5.6 to -5.4 \\
KA23 & 262 & calcite & 190 to 220 & -5.7 to -5.1 \\
KA23 & 348 & calcite & 220 to 240 & -5.7 to -5.3 \\
KA26 & 543 & calcite & 250 to 270 & -6.6 to -6.3 \\
KA30 & 540 & calcite & 260 to 280 & -5.3 to -5.0 \\
KA48 & 520 & calcite & 185 to 220 & -6.3 to -5.3 \\
KA48 & 775 & calcite & 230 to 250 & -2.1 to -1.7 \\
KA48 & 840 & calcite & 230 to 250 & -6.1 to -5.7 \\
\hline
\end{tabular}

As shown in Fig. 5.21, the $\delta^{18} \mathrm{O}$ values of the modern Kawerau aquifer waters are higher than the $\delta^{18} \mathrm{O}$ values of the local meteoric water (which plot along the GMWL). The higher aquifer values are most likely due to water-rock interaction, with the modern aquifer waters ranging from $\sim-4.1$ to $-2.3 \%$. When the oxygen isotope values of the fluid in equilibrium with hydrothermal quartz and calcite are plotted (Fig. 5.21), most fall in the range of the modified meteoric water, implying that at the time of crystallisation conditions were similar to the modern system. Exceptions to this are in wells KA23, KA26, KA30 and KA48, where some samples show a greater enrichment in ${ }^{18} \mathrm{O}$. 


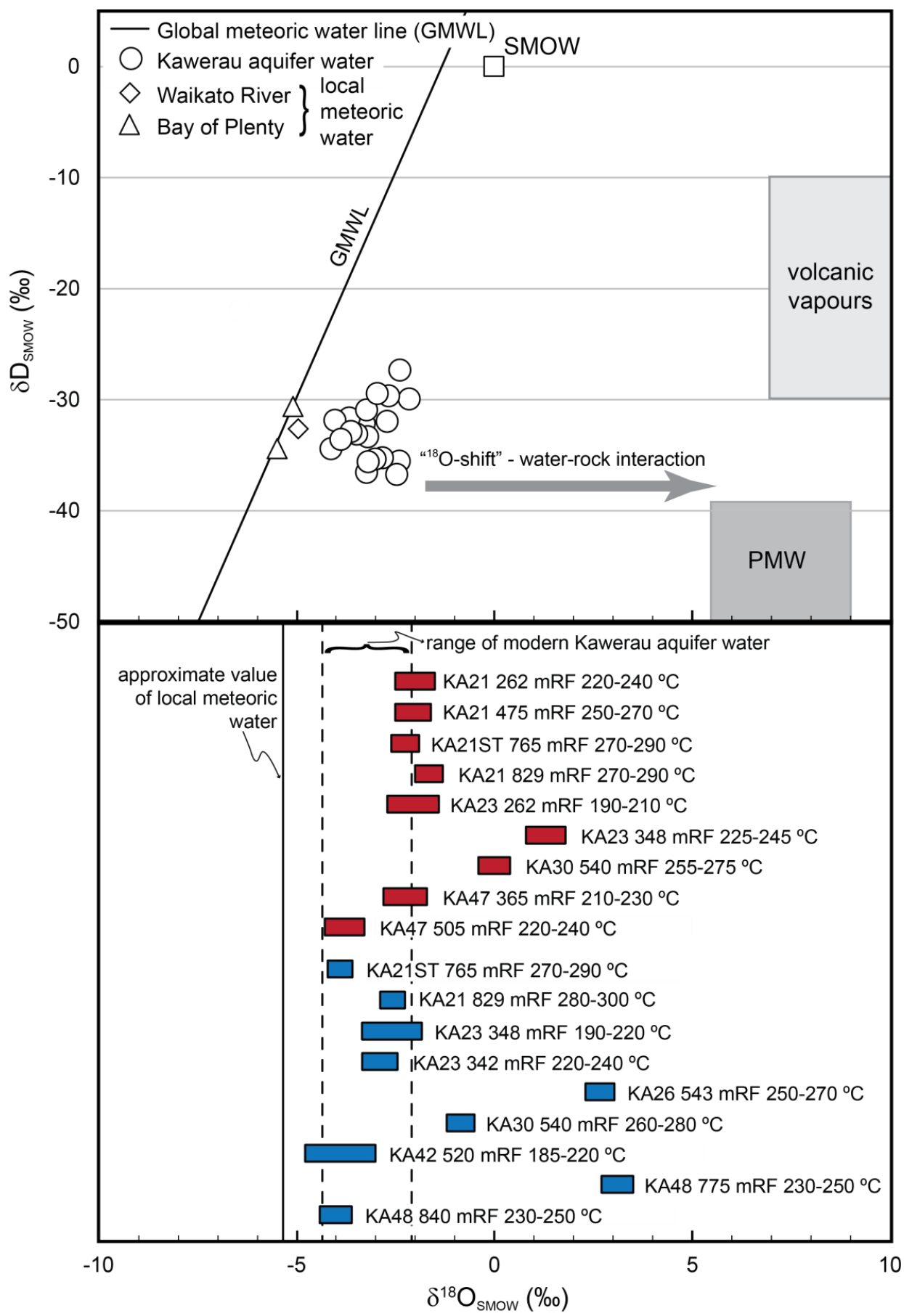

Figure 5.21 $\delta^{18} \mathrm{O}$ values of the calculated fluids in equilibrium with quartz and calcite (red and blue bars, respectively) using measured temperature ranges. The temperatures are estimated from primary fluid inclusions (Tables 5.2 - 5.8) and well temperatures from MRP (2013). Circles are values calculated (at $\mathrm{T}_{\mathrm{qz}}$ ) for modern Kawerau aquifer waters from Mroczek et al. (2001) and MRP (2013). Volcanic vapour values from Giggenbach (1992), PMW (primary magmatic water) values from Taylor (1979). GMWL - Global Meteoric Water Line (Craig, 1961).

\subsubsection{Calcite $\delta^{18} \mathrm{O}$ values}

A plot of the $\delta^{18} \mathrm{O}$ values of calcite against depth in the wells show most of the values are in equilibrium with fluids that have values similar to the present day aquifer waters ("present-day trend' and current isotopic equilibrium) encompassed by curves $\mathrm{Y}$ and $\mathrm{Z}$ (Fig. 5.22). The 
curves were calculated by Christenson (1987) using the calcite-water fractionation data of O’Neil et al. (1969) as a function of depth, with curve Y applying to higher temperature wells in the main upflow zone and curve $\mathrm{Z}$ being a lower temperature equivalent of curve $\mathrm{Y}$ applying to wells located away from upflow zone. The data collected in this study are in agreement with those of Christenson (1987) and Absar (1988).

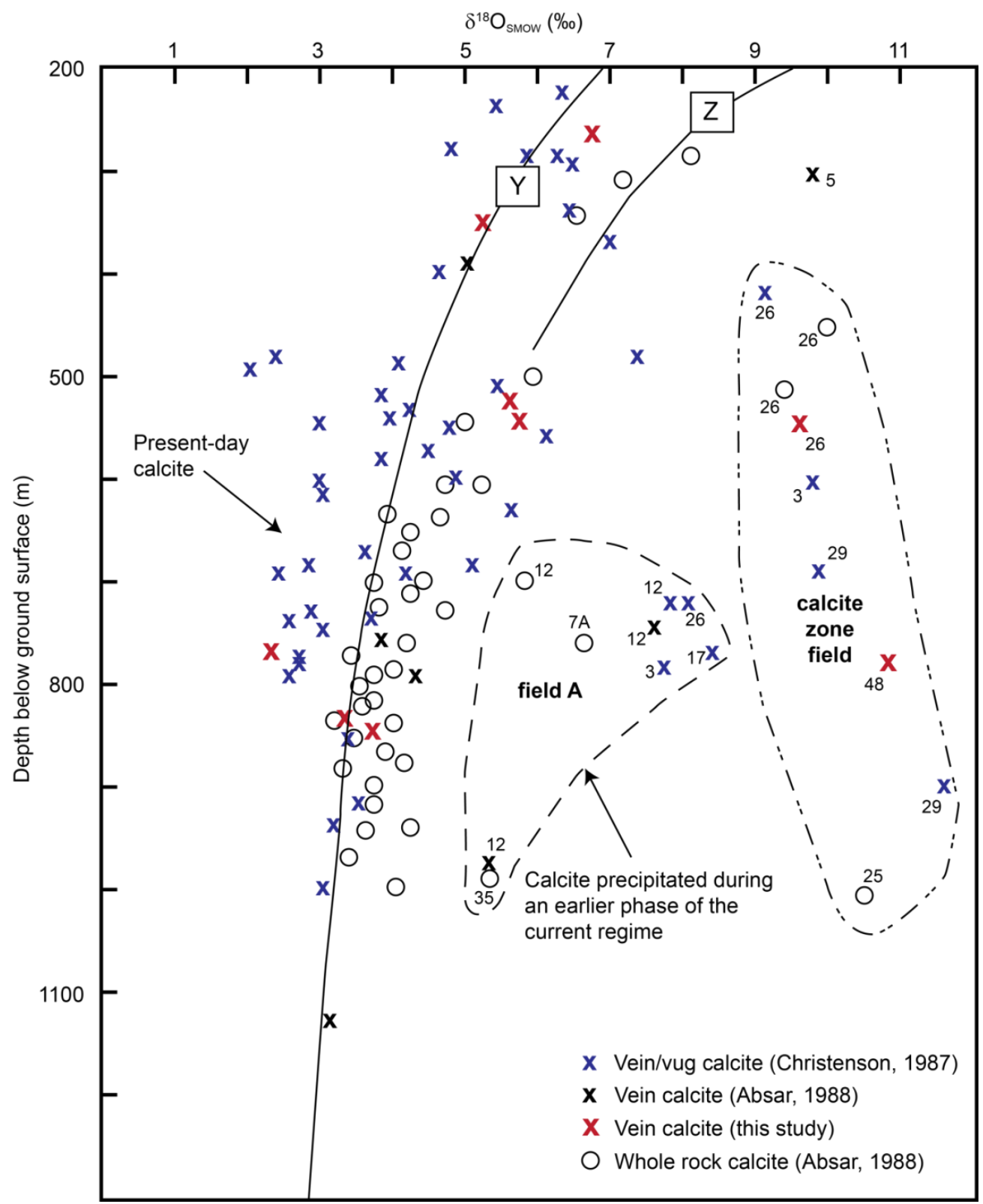

Figure 5.22 $\delta^{18} \mathrm{O}$ values in calcite plotted as a function of depth. Curve Y shows the expected 'present-day trend' of $\delta^{18} \mathrm{O}$ variations with depth. Curve $\mathrm{Z}$ is a lower temperature equivalent of curve $\mathrm{Y}$. The scatter above curves $\mathrm{Y}$ and $\mathrm{Z}$ is interpreted to be related to the presence of two earlier generations of geothermal calcite. Adapated from Absar (1988) and including data from Christenson (1987).

Figure 5.22 reveals the samples that are not consistent with the 'present-day trend' of $\delta^{18} \mathrm{O}$ values for calcite (field $A$ and calcite zone field in Fig. 5.22). These samples are 5 to $10 \%$ more positive in their $\delta^{18} \mathrm{O}$ values than the calcite plotting along the "present-day calcite" trend. 
Wells with data plotting in the $\delta^{18} \mathrm{O}$ enriched calcite zone field are from the south of the field, with KA26-543 mRF calcite being representative of these data. The higher $\delta^{18} \mathrm{O}$ value of 9.6 \%o for vein calcite from KA26-543 mRF could be due to crystallisation from either a cooler or more $\delta^{18} \mathrm{O}$ enriched water. Using the range of present-day aquifer water $\delta^{18} \mathrm{O}$ values from Mroczek et al. (2001) and MRP (2013) (Fig. 5.21), equilibrium temperatures of 136 to $180{ }^{\circ} \mathrm{C}$ are calculated using the fractionation factors of O’Neil et al. (1969). Interpreted natural state well temperatures at this depth are $255^{\circ} \mathrm{C}$ (MRP, 2013), which would indicate the possibility of a temperature inversion at this level of $>75^{\circ} \mathrm{C}$. Temperatures from primary fluid inclusions in KA26-543 mRF calcite, however, are around $270{ }^{\circ} \mathrm{C}$, ruling out a temperature inversion and providing conclusive evidence of the involvement of a relatively high $\delta^{18} \mathrm{O}$ water.

Another field of relatively high $\delta^{18} \mathrm{O}$ calcite (not sampled in this study) is plotted in Fig. 5.22 from the work of Christenson (1987) and Absar (1988). Similar to the data that plot in the calcite zone field, data from wells plotting in field A indicate lower calcite equilibrium temperatures when compared to current well temperatures and fluid inclusion temperatures. Christenson (1987) and Absar (1988) suggested that these results indicated that the calcites were crystallised at temperatures close to those of the present-day, but from a fluid with relatively higher $\delta^{18} \mathrm{O}$ values.

\subsubsection{Quartz $\delta^{18} \mathrm{O}$ values}

The anomalous $\delta^{18} \mathrm{O}$ values of quartz in the southern well KA30-540 mRF (Fig. 5.21) support the presence of an ${ }^{18} \mathrm{O}$-enriched fluid. For the range of present-day Kawerau aquifer water $\delta^{18} \mathrm{O}$ values (Fig. 5.21), and the $\delta^{18} \mathrm{O}$ value of $8.3 \%$ for vein quartz in KA30 at $540 \mathrm{mRF}$ depth, equilibrium temperatures of 188 to $219^{\circ} \mathrm{C}$ are calculated using the fractionation factors of Zheng (1993). Interpreted natural state well temperatures at this level are $264{ }^{\circ} \mathrm{C}$ (MRP, 2013), which would indicate a possible temperature inversion of $>45^{\circ} \mathrm{C}$. Such an inversion can be ruled out, however, as the alteration mineral assemblage (illite, wairakite) does not indicate the presence of cool water and instead suggests crystallisation from water with a relatively high $\delta^{18} \mathrm{O}$ value.

The enriched ${ }^{18} \mathrm{O}$ value for KA23-348 $\mathrm{mRF}$ (also in the southern part of the field) at this shallow depth is likely to be due to incursion of unexchanged cooler meteoric fluid, rather than from an enriched fluid source (Allis et al., 1995). 


\subsubsection{4 $\quad \delta^{13} C$ values}

The carbon and oxygen isotopic values of the fluids in equilibrium with the hydrothermal calcite have been calculated using the fractionation factors from Ohmoto and Rye (1979) and O’Neil et al. (1969) respectively. A plot of $\delta^{18} \mathrm{O}_{\mathrm{H} 2 \mathrm{O}}$ vs. $\delta^{13} \mathrm{C}_{\mathrm{CO} 2}$ values (Fig. 5.23) shows that most of the $\delta^{13} \mathrm{C}_{\mathrm{CO} 2}$ values of $\mathrm{CO}_{2}$ in equilibrium Kawerau calcite lie within the range of mantle-derived $\mathrm{CO}_{2}$ (e.g. magmatic) which has $\delta^{13} \mathrm{C}$ values between -4 and $-8 \%$ (Rye and Ohmoto, 1974; Pineau and Javoy, 1983). It is likely that the more positive $\delta^{13} \mathrm{C}$ values (Fig. 5.23) are in part due to carbon assimilated from calcite marine sediments within the greywacke. $\mathrm{CO}_{2}$ from thermal decomposition of sedimentary carbonate would have a $\delta^{13} \mathrm{C}$ value of -2 to $2 \%$ (Lyon and Hulston, 1984). Some of the variation in $\delta^{13} \mathrm{C}_{\mathrm{CO} 2}$ values is likely due to degassing of $\mathrm{CO}_{2}$ during boiling events, as the calcite sampled is in a bladed, platy form, indicative of precipitation in boiling conditions (Zheng, 1990; Simmons and Christenson, 1994)

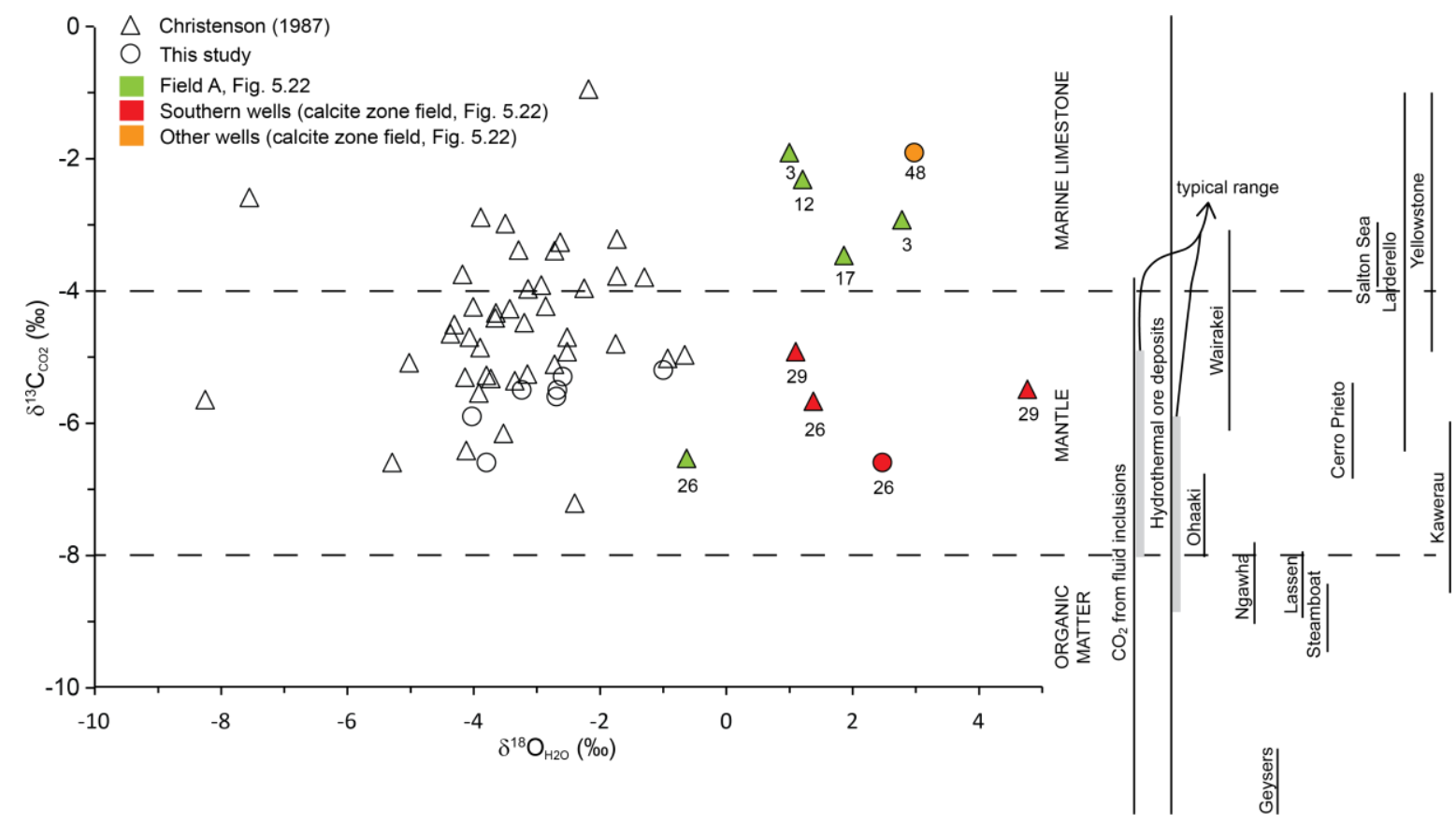

Figure 5.23 Calculated $\delta^{18} \mathrm{O}_{\mathrm{H} 20}$ vs. $\delta^{13} \mathrm{C}_{\mathrm{CO} 2}$ values from calcite plotted as a function of depth. Colour symbols are from the fields deemed anomalous in Fig. 5.22. Plotted on the right are $\delta^{13} \mathrm{C}$ values of $\mathrm{CO}_{2}$ from various geothermal fields, hydrothermal deposits and fluid inclusions (Absar, 1988), along with the ranges of $\delta^{13} \mathrm{C}$ values for the major reservoirs of carbon in hydrothermal systems (Rye and Ohmoto, 1974; Pineau and Javoy, 1983; Field and Fifarek, 1985).

\subsubsection{Alteration events and chronostratigraphy}

Using the isotopic data of this study and earlier studies by Christenson (1987) and Absar (1988), coupled with the observed hydrothermal mineral assemblages and chronostratigraphy 
developed in Chapters 2 and 3, it is possible to link hydrothermal alteration events with inferred pulses of heat input into the system from deep magmatism.

Taking estimates of the oxygen isotope values of fluids during earlier alteration events (described in section 5.1.2) the following chronological sequence of events is suggested (after Absar, 1988 and Absar and Blattner, 1985), with the numbering referring to Figure 5.24:

1. Wairakite-prehnite event: fluid $\delta^{18} \mathrm{O}$ values of -1 to $1 \%$ at temperatures of around 280 to $300{ }^{\circ} \mathrm{C}$. These values suggest a positive $\delta^{18} \mathrm{O}$ shift of $\sim 5$ to $7 \%$ in the meteoric water derived recharge for the system (from a meteoric $\delta^{18} \mathrm{O}$ value of $-5.7 \%$ : Stewart, 1980).

2. Transitional state between wairakite-prehnite event and calcite zone event: fluid $\delta^{18} \mathrm{O}$ values of 1.7 to $3.2 \%$ at temperatures of around $290{ }^{\circ} \mathrm{C}$. It is possible that quartz veins with these values represent veins deposited during a period of changing conditions between the wairakite-prehnite and calcite zone events.

3. Calcite zone event: fluid $\delta^{18} \mathrm{O}$ values of 4.4 to $7.8 \%$ at temperatures of $290{ }^{\circ} \mathrm{C}$ measured from fluid inclusions. The enriched $\delta^{18} \mathrm{O}$ isotope values indicative of this event are found in southern wells in the field. Calcite formed in this event plots in the "calcite zone" of Fig. 5.22.

4. Transitional state between calcite zone event and present-day activity: variations in $\delta^{18} \mathrm{O}$ fluid isotope values since the formation of the calcite zone occur in calcite $\delta^{18} \mathrm{O}$ values in the northern part of the field. A fossil upflow zone in the region of KA31, accompanying an epidote dominated mineral assemblage in the basement rocks in this area, is inferred by Absar (1988) to have formed during an earlier phase of the current activity when dissolved $\mathrm{CO}_{2}$ in the fluid was relatively low. Calcite from this transitional stage is formed from fluids with isotopic values of -1.5 to $2.9 \%$ at temperatures between 260 and $290^{\circ} \mathrm{C}$ and plot in field A in Fig. 5.22.

5. Present-day activity: characterised by calcite, quartz, calc-silicates, illite and adularia and an abundance of epidote and clinozoisite, the present-day alteration assemblage is forming from fluids with a $\delta^{18} \mathrm{O}$ value of -2.7 to $-2.5 \%$, showing a ' $\delta^{18} \mathrm{O}$ shift' from meteoric water of $2.5 \%$ (cf. Stewart, 1980). 


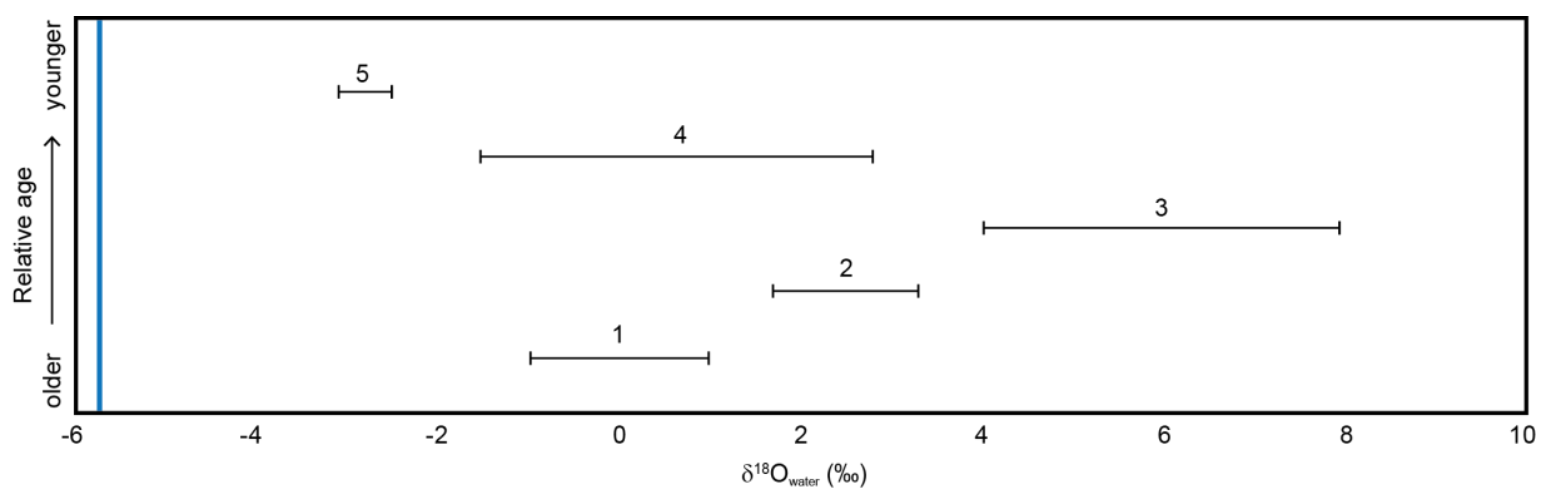

Figure 5.24 Inferred variations in calculated $\delta^{18} \mathrm{O}$ fluid isotopic values during the history of the Kawerau geothermal system (Absar, 1988). 1) wairakite-prehnite zone event, 2) quartz veins deposited during the transitional stage between wairakite-prehnite, and calcite zone events, 3) calcite zone event, 4) transitional state between calcite zone event and present-day activity and, 5) present-day activity. The vertical blue line shows the $\delta^{18} \mathrm{O}$ value of the local meteoric water (Stewart, 1980).

It is proposed here that the earliest two isotopic signatures (1 and 2 in Fig. 5.24) are related to heat supplied by the magmatic system(s) that gave rise to the Caxton Formation sills and extrusive domes (hereafter referred to as the Caxton magmatic system). Evidence from oxygen isotope values indicates that fluids in this event would have been meteoric-water dominated. There is no evidence of input of oxygen from a magmatic source into the system during this early phase of hydrothermal activity, suggesting that the deep rhyolitic magma was not actively degassing and was acting solely as a heat source driving a convection plume with the waters of meteoric origin. It is inferred during events 1 and 2 (Fig. 5.24) that fluid compositions would have been similar to the present-day system. The presence of a hydrothermal eruption breccia beneath the Caxton Formation extrusive member in KA25 (discussed in Chapter 3) points to the hydrothermal eruption deposit being related to the intrusion and hydrofracturing activated by the start-up of the Caxton magmatic system.

The "calcite zone event" ( 3 in Fig 5.24) which is largely confined to the south of the field shows evidence for input of a more positive $\delta^{18} \mathrm{O}$ value fluid. This fluid could be due to magma degassing and primary neutralisation (cf. Giggenbach, 1981; Hedenquist, 1986). It is suggested here that this event is related to the initiation and growth of the Putauaki magmatic system. Degassing of the early intruded magma of the Putauaki magmatic system would increase the $\delta^{18} \mathrm{O}$ value of the hydrothermal fluid, consistent with the relatively more positive values being confined to the southern part of the field. The addition of magmatic $\mathrm{CO}_{2}$ to the system would have created an overpressure situation, causing initiation of hydraulic fracturing and facilitating the upflow of cooling fluids. Large pressure drops and degassing associated with the hydraulic fracturing would have resulted in the precipitation of calcite (cf. Fournier, 1985). As hydraulic fracturing propagates at a fast rate (Grindley and Browne, 1976), large and almost instantaneous pressure drops would have resulted in rapid precipitation of calcite, and 
consequent sealing of permeable zones. The sealing of fractures in the south of the field would explain why the ${ }^{18} \mathrm{O}$-enriched waters did not move north into the field. It may be assumed that the calcite zone event was relatively short-lived within the time framework of the age of hydrothermal activity at Kawerau. The andesitic/dacitic Putauaki composite cone first erupted around $8 \mathrm{ka}$ (Carroll et al., 1997), but earlier hydrothermal eruption breccias imply that magma was intruded to shallow depths as early as $\sim 16 \mathrm{ka}$ (Nairn and Wiradiradja, 1980, constrained by ages from Lowe et al., 2013: see Chapter 3). The hydraulic fracturing related to the calcite event could have propagated to surface, resulting in the hydrothermal eruptions. These inferences would imply that the modern Kawerau geothermal system was initiated around $\sim 16 \mathrm{ka}$.

Since the formation of the "calcite zone", hydrothermal activity and formation of the modern hydrothermal alteration assemblage at Kawerau has migrated north-eastward (Absar and Blattner, 1986). A transition period was marked by variations in the fluid isotopic values (number 3 in Fig. 5.24 and field A in Fig. 5.22). It is likely that these variations mark a cooling of the deep magmatic body and a decrease in magmatic degassing, resulting in a transition of the fluid from the relatively more positive $\delta^{18} \mathrm{O}$ value fluids in the calcite zone event to dilute, predominantly meteoric conditions that persist today.

\subsection{SUMMARY AND CONCLUSIONS}

There is little evidence in the Kawerau geothermal system of significant magmatic input. Fluid inclusion microthermometry points to a predominantly meteoric source for water in the system. Given the high through-put of water from this source, the geothermal system would be buffered by the meteoric fluids. Dilution and mixing would mask the signature of any magmatic fluid input.

Although there are local examples of disparities between the interpreted natural state temperatures and fluid inclusion temperatures, in general the fluid inclusion microthermometry data agree well with interpreted natural state temperatures. Stratigraphic and structural interpretations (Chapter 3) show there has been little change in elevation relative to sea level in the Kawerau area. Although fluid inclusion data has some variation, much of the data plot on or near the current BPD curve. These data are either from hydrothermal minerals forming under the current conditions, or if from hydrothermal minerals were deposited in the past, support the inference of little fluctuation in elevation at Kawerau as water table would have been at a similar elevation. 
Similarly, there is little isotopic evidence of a significant magmatic fluid component in the hydrothermal fluid from which Kawerau secondary quartz and calcite were precipitated. Local meteoric water has been ${ }^{~}{ }^{18} \mathrm{O}$-shifted' through water-rock interaction, but is clearly distinguished from any primary magmatic fluid signature. There are however enriched $\delta^{18} \mathrm{O}$ values associated with the calcite zone event, which is attributed to a short-lived pulse of magmatic $\mathrm{CO}_{2}$ and fluids related to the initiation of the andesite-dacite Putauaki magmatic system. This could be likened to the short-term $\mathrm{CO}_{2}$ release events observed in the Long Valley caldera that are attributed to dome resurgence and dike emplacement beneath Mammoth Mountain with associated earthquake swarms (Hilton, 1996; Sorey et al., 1998). Earlier $\delta^{18} \mathrm{O}$ isotopic values attributed to a hydrothermal system related to heat input from the rhyolitic Caxton magmatic system are meteoric in origin, indicating that the magma was acting only as a heat source to drive the hydrothermal system, and was not contributing significant amounts of magmatic oxygen or $\mathrm{CO}_{2}$. Mafic magma is typically enriched in $\mathrm{CO}_{2}$ relative to silicic magma (Lowenstern, 2001). A low $\mathrm{CO}_{2}$ content of the earlier silicic magma body feeding the rhyolitic Caxton magmatic system could explain the lack of magmatic fluid input. In contrast, the mafic source for the andesite-dacite Putauaki magmatic system would have undergone active degassing of $\mathrm{CO}_{2}$ (Werner and Cardellini, 2005), and led to the magmatic signature in the early fluids of the system.

Signatures of magmatic fluids tend to be masked or erased due to later overprinting by large volumes of meteoric water, which likely represents $>95 \%$ of the water ultimately convected during cooling of an intrusion in the shallow crust (Hedenquist and Lowenstern, 1994). Paradoxically, the evidence for meteoric-water dominance in hydrothermal systems is most obvious where magmatism was most voluminous, because the large magmatic heat source creates large and long-lived cells of convecting meteoric water, convection that will erase most of the evidence for any early component of magmatic water (Hedenquist and Lowenstern, 1994). 
Chapter 5 
CHAPTER 6

SUMMARY AND CONSIDERATIONS FOR FURTHER WORK 


\subsection{SUMMARY OF RESULTS OBTAINED IN THIS WORK}

Management and development of high-temperature geothermal systems demands accurate knowledge of the local geological conditions, particularly where they impact on the hydrology of the high-temperature geothermal resource. Prior to this study at Kawerau, the locations of the basement faults, their offsets and history of movement and the geological controls on the thermal fluid upflows were not well understood. Similarly, the age of the Kawerau geothermal system was poorly constrained.

This study of the Kawerau Geothermal Field provided an opportunity to use an integrated approach to produce a new geological framework for the field and develop a greater understanding of the structural evolution of both the local geothermal system and how it related to evolution of the wider TVZ. Using a robust approach of detailed thin section petrography and drill core/cutting description, combined with zircon $\mathrm{U}-\mathrm{Pb}$ dating of key units, this study has resolved several uncertainties around the age of the rocks and evolution of the hydrothermal system.

Although the geological approaches and techniques utilised in the study are well established, their application to an integrated study of a geothermal system in New Zealand has not previously been undertaken. Petrographic studies to determine stratigraphic correlations and fluid inclusion analyses to determine fluid chemistry and temperature are commonly applied to the development and understanding of geothermal fields. What is novel in the New Zealand context is taking these data and integrating them with a comprehensive dating programme, and then using this information to inform and create a model 3-D visualisation of a geothermal field. Although 3-D geologic modelling has routinely been applied in the petroleum industry, such an approach is still relatively new to the geothermal industry. Some of the main outcomes of this research are summarised in the following sections.

\subsubsection{U-Pb dating}

In TVZ geothermal systems, correlation of hydrothermally altered rocks has been challenging, due to similarities in lithologies and the destruction by hydrothermal alteration of distinctive chemical, mineralogical and groundmass textural characteristics. To a certain extent, correlations can be made on the basis of petrographic characteristics (rock type, crystal content, presence and abundance of recognisable mineral phases). This work has shown, however, that these initial correlations are often incorrect as rocks of widely differing ages may 
show superficially similar petrographic characteristics. U-Pb ages have been obtained by Secondary Ion Mass Spectrometry (SIMS) techniques (using SHRIMP-RG instruments at Stanford University or the Australian National University) on zircons from altered volcanic units penetrated by drillholes at Kawerau Geothermal Field (Milicich et al., 2013a). The resulting crystallisation age spectra have been interpreted in terms of ages of eruption or intrusion of the rock units, using the ${ }^{230} \mathrm{Th}$-corrected ${ }^{206} \mathrm{~Pb} /{ }^{238} \mathrm{U}$ age determinations. This work has shown that $\mathrm{U}-\mathrm{Pb}$ dating, combined with petrographic and hand specimen descriptions, is less ambiguous and can be used to differentiate or correlate between units within and beyond the geothermal field. In this sense, as well as adding age estimates to the key units, this work has in particular clarified the previously confused situation with respect to the early ignimbrites inconsistently labelled as Opunoke and Te Teko ignimbrites, and the presence at multiple stratigraphic levels of the previously labelled Caxton and Onepu rhyolites (Bignall and Harvey, 2005).

The age spectra obtained from the Kawerau samples, and inferred correlations with three surficial units previously dated by ${ }^{40} \mathrm{Ar} /{ }^{39} \mathrm{Ar}$ techniques suggests that the weighted mean of the youngest $20-30 \%$ of the grains analysed provides a close approximation to the eruption or intrusion age of the unit concerned. The weighted average applied to all age data can in some cases be skewed by incorporation of older, unrelated grains, resulting in very high MSWD (Mean Squares of Weighted Deviates) values, but the age at the peak value of the pdf curve frequently provides a reliable maximum age even where there is a tail of older grains. Older material may be introduced via xenolithic or xenocrystic material in the tuffs themselves, whereas contamination of younger material in cuttings may occur via downhole mixing from overlying material. Despite these possibilities, contamination by younger or older grains has not been a major issue in this study to the extent that it obscured identification of the primary age characteristics in samples. In situations where the proportions of the ${ }^{206} \mathrm{~Pb}$ concentration contributed by common- $\mathrm{Pb}$ are high, the age data still appear to be accurate (albeit less precise) with respect to values obtained in pristine grains with low common- $\mathrm{Pb}$. A cut-off of as high as $70 \%$ of the ${ }^{206} \mathrm{~Pb}$ concentration contributed by common- $\mathrm{Pb}$ still yields acceptable age estimates for fingerprinting rocks that cannot be dated by other means.

\subsubsection{Geological architecture}

As a result of the chronology provided by $\mathrm{U}-\mathrm{Pb}$ dating of zircons, the stratigraphic sequence has been redefined and renamed. The chronostratigraphic framework has been used to reconstruct the geological history of the area encompassed by the modern field, including the 
presence of local magmatism, and the faulting and subsidence histories which can then be related to shifting patterns of regional tectonic activity. Three major groups of material form the rocks at Kawerau above the greywacke basement: (a) primary pyroclastic rocks (generally referred to as tuffs) and their resedimented equivalents, (b) intrusive and extrusive coherent rhyolite that was emplaced as magma, and (c) sediments plus palaeosols.

Most of the tuff units dated represent ignimbrites that were demonstrably (e.g. Kidnappers ignimbrite) or probably erupted from sources well outside the Kawerau area. These units are valuable as time-plane markers for inferring the contemporaneous local topographic relief and displacement timings across fault planes (Milicich et al., 2013b), but have no relevance to delineating underlying magmatic sources for hydrothermal activity in the Kawerau area. Deposition of ignimbrite within the Kawerau area was distinctly episodic with bursts of eruptive activity at $1.45-1.35 \mathrm{Ma}$ (Te Teko Formation), $1.0 \mathrm{Ma}$ (Raepahu Formation), 0.5 0.6 Ma (Karaponga Formation) and 0.32 Ma (Matahina Formation). The first and third of these clusters fall into gaps in the primary onshore ignimbrite record (Houghton et al., 1995). These two time periods do, however, see rapid accumulation of distal ash deposits in the marine record east of the North Island (Carter et al., 2003, 2004; Allan et al., 2008) and in the Wanganui Basin (Pillans et al., 2005), although in general it is not possible with available data to correlate these with the specific units found at Kawerau. The second cluster is correlated with the combined products of the Kidnappers and Rocky Hill eruptions at $~ 1.0 \mathrm{Ma}$, mapped elsewhere as the landscape-forming Raepahu Formation (Edbrooke, 2005; Leonard et al., 2010), and with thinner deposits reported widely as the Potaka Tephra (e.g. Shane, 1991; Carter et al, 2004). Intervals of ignimbrite previously labelled as Rangitaiki Ignimbrite (ca. 350 ka, where dated in its primary surface outcrop: Leonard et al., 2010) have been shown to be much older, and the intervals have now been redistributed within the formations mentioned above.

Numerous bodies of coherent rhyolite to rhyodacite previously mapped in drill core and cuttings in the field (Browne, 1978a) can be shown from geochronology and petrography to represent a combination of dome extrusions and intrusions, rather than domes extruded on many different occasions through the history of the field. The Caxton Formation rhyolites, erupted at $0.36 \mathrm{Ma}$, are represented by crystal richer and crystal-poorer lithologies, each of which is represented by domes and sill intrusions. The $0.138 \mathrm{Ma}$ Onepu Formation rhyodacite is represented by surficial domes and two dike intersections at depth. The corresponding change in orientation of the minimum principal stress axis $\left(\sigma_{3}\right)$ from vertical at $0.36 \mathrm{Ma}$ (for sill emplacement) to horizontal (for dike emplacement) by $0.138 \mathrm{Ma}$ reflects the onset of the 
stress regime associated with modern TVZ rifting.

The early sediments at Kawerau are dominated by greywacke gravels of the Waikora Formation. Unlike the current northeast-southwest normal faulting in the geothermal field area, consistently downthrowing to the northwest as part of the eastern margin to the modern TVZ rift system, the gravels infill half-grabens inferred to have been generated by strike-slip faulting. Any topographic relief generated at this time was subdued by the time a regionally distributed ignimbrite was deposited over the field at $1.46 \pm 0.01 \mathrm{Ma}$. The age data and associated correlations show that post-1.46 Ma normal faulting has accompanied episodic subsidence of the Kawerau area, with movement along both northeast-southwest structures (associated with the geometry of the modern TVZ) and reactivation of northwest-southeast structures that saw the most displacement prior to $1.46 \mathrm{Ma}$.

Intervals of sediments previously allocated to the Huka Falls Formation (HFF) cannot be part of this formation. Where first defined at Wairakei (Grindley, 1965) the formation post-dates the buried Whakamaru group ignimbrites and so cannot be the time equivalent of any of the sedimentary packages we define at Kawerau. These intervals have now been renamed as part of the Tahuna and Onerahi formations, depending on their stratigraphic position.

$\mathrm{U}-\mathrm{Pb}$ age determinations, when coupled with interpretations of the geological history in the Kawerau area show that the modern geothermal system is a young feature. This feature is, however, superimposed on an area that has seen previous occasions when magmatic activity directly underlay it, as evidenced by coherent lavas and intrusive rocks that were probably fed from immediately underlying magma bodies. Of all the episodes of local magmatism, only those associated with the 0.43 - 0.36 Ma Caxton and Late Quaternary Putauaki systems have left clear influence on the modern field. Between 0.43 and $0.36 \mathrm{Ma}$ a sustained local magmatic source is inferred to have been present, feeding the rhyolite lavas and intrusions of the Caxton Formation, plus the slightly older pyroclastic rocks of the Tahuna Formation. The young Putauaki system is considered specifically responsible for the thermal and hydrothermal alteration characteristics of the modern Kawerau geothermal system. The youthful age $(2.4-$ $8.35 \mathrm{ka}$ ) and composite construction of Putauaki volcano, together with the presence of slightly older hydrothermal eruption breccias $(16-9 \mathrm{ka})$, strongly suggest that the presence of an active magma reservoir or hot pluton supplies the thermal support for the modern field. In between these episodes we suggest that the area was hydrothermally quiescent. The heat supplied by successive magmatic systems beneath the Kawerau Field has likely utilised similar permeability pathways (that is, fault systems) and reoccupied the volume of the geothermal system previously in place. Though fluid changes associated with the cooling of a magmatic 
source would likely promote silica self-sealing, re-activation of faults independently of any heat source could maintain these pathways.

Rates of accumulation of deposits and subsidence across the Kawerau Field area have been non-uniform. Long-term average subsidence rates derived from the depths to the top contacts of dated units are generally $<1 \mathrm{~mm} / \mathrm{yr}$. The $2 \pm 1 \mathrm{~mm} /$ year modern rates of regional tectonic related subsidence cannot have been active for more than $\sim 50,000$ years, based on depths to the top of the 0.322 Ma Matahina ignimbrite.

\subsubsection{3-D modelling}

During the exploration and development of a geothermal resource it is crucial to have confidence in the delineation of the extent of reservoir rocks, permeable horizons and fluid pathways. This knowledge optimises targeting of boreholes, which reduces risk and drilling costs for exploration purposes, and allows for the most effective on-going management of the resource through fluid-flow models. This thesis contributes to a new, improved model for the Kawerau Geothermal Field through blending the new geological knowledge with visualisation tools suitable for use by non-geologists responsible for the effective management of the resource (i.e. numerical modellers, field managers, etc.).

Complex geological and structural frameworks are, however, often difficult to visualise in 2$\mathrm{D}$, and the development of a 3-D visualisation model of the geology hosting the geothermal system is key to understanding complex data sets. Despite the U-Pb dating, stratigraphic studies and 3-D model being presented as separate chapters in this thesis, these bodies of work were closely interrelated and integral in revising the understanding of the geology in the Kawerau area. Ideas and potential correlations were tested in 3-D space in the initial stages of selecting key samples for dating and then revised once the dates were available. This iterative process allowed a robust stratigraphic framework to be developed that would not have been achieved with use of any of these techniques on their own.

The ability to model the geological information in a 3-D interface has provided new insights regarding the geological and structural framework of the Kawerau area. It has impacted on our understanding of the controls on deep-seated permeability in the Kawerau geothermal system. This understanding has direct implications for the on-going development and management of the geothermal resource, the Kawerau Geothermal Field. The 3-D geological framework supports the effective adaptive management of the field through the modelling of structural fabric and extent of permeable and fractured units. This aids in defining the well targeting and 
reinjection strategies of the field operators.

\subsubsection{Fluid and heat sources}

There is little evidence in the Kawerau geothermal system of significant direct magmatic input. Fluid inclusion microthermometry and stable isotope analyses indicate a predominantly meteoric source for water in the system which buffers the nature of the geothermal system. Early signatures of magmatic fluids may be masked or erased owing to later overprinting by large volumes of meteoric water, which represents $>95 \%$ of the water ultimately convected during cooling of an intrusion in the shallow crust (Hedenquist and Lowenstern, 1994).

Although there are some instances where there is disparity between the fluid inclusion temperatures and natural-state temperatures, in general the temperature estimates agree well between those inferred from fluid inclusions and those measured in the modern field. This observation would indicate that much of the fluid inclusion data are representative of the conditions in the modern geothermal system, or if from hydrothermal minerals deposited in the past indicate fluid conditions were similar to present-day. It is likely though in a system buffered by meteoric water, that unless the fluids were significantly more saline than present day, that fluid inclusions would yield the same estimates of entrapment temperature and salinity regardless of their age.

Stable isotope analyses, combined with alteration zones defined by Absar (1988) suggest that the Kawerau Field samples show an earlier alteration assemblage and a modern assemblage with a meteoric water signature, separated by a calcite-dominated event with enriched $\delta^{18} \mathrm{O}$ values. These $\delta^{18} \mathrm{O}$ enriched values have been attributed (Chapter 5) to a short-lived pulse of magmatic $\mathrm{CO}_{2}$ related to initiation of the Putauaki magmatic system at roughly $16 \mathrm{ka}$. An earlier event attributed (Chapter 5) to the Caxton magmatic system is meteoric in origin, indicating that the magma was acting only as a heat source to drive the hydrothermal system, and was not actively contributing magmatic fluids.

This work presented in this thesis suggests there have been two pulses of geothermal system in the Kawerau area since approximately 400,000 years B.P. The state of the system between that driven by the earlier Caxton magmatic system and the current Putauaki driven system is not known. It is very likely that geothermal activity waned or ceased between these events as heat was lost from the initial Caxton magmatic system. The volumes of magma represented either by the Caxton Formation rhyolites themselves $\left(\sim 1 \mathrm{~km}^{3}\right)$, or the total volume of magma inferred to have generated the rhyolites by assimilation/fractional crystallisation $\left(\sim 10 \mathrm{~km}^{3}\right)$ 
would be able to feed an active geothermal system only for periods of the order of $10^{2}$ to $10^{4}$ years (e.g. Cathles, 1977). The basement beneath Kawerau is 'leaky' due to a series of crosscutting faults and tectonic activity which keep fluid (and magma) pathways open. It is inferred from the work presented in this thesis that geothermal systems need not be systems continuously active for hundreds of thousands of years, but can become extinct, then be revived in the same geographic location utilising the same pathways as previous systems, controlled by the continued reactivation of fault-induced permeability.

\subsubsection{Geothermal field management}

This research has provided information that is able to be utilised in improving geothermal field management and future use. The chronostratigraphic framework developed into a 3-D visualisation model can be used to assist reservoir interpretation where data on the formation of a geothermal system is worked into the conceptual model of the geothermal system. These conceptual models inform the development or upgrading of numerical simulation models of the given system. The geology can be used in the numerical simulation model by providing a basis for consistently assigning model block properties. The 3-D interface allows visualisation of interactions between the geology and field/reservoir parameters.

A more tightly constrained understanding of the geology and faulting within a field should facilitate improved borehole targeting. Improved fault location within a field where structural permeability is important provides data to the field developer to better target the inferred structural fabric with deviated wells. This approach increases the possibility of encountering permeable flow paths containing hot fluids for production purposes. The information can also be used to target reinjection wells, as injected fluid may track through fracture pathways and certain structures may be sought to be avoided to avoid premature detrimental cooling.

\subsection{ANSWERS TO THE KEY QUESTIONS POSED IN THIS THESIS}

The key questions posed in Chapter 1 are addressed in light of the findings of this $\mathrm{PhD}$ research:

What are the ages of major stratigraphic units?

The geology of the Kawerau geothermal system is summarised in cartoon form in Fig. 6.1. 


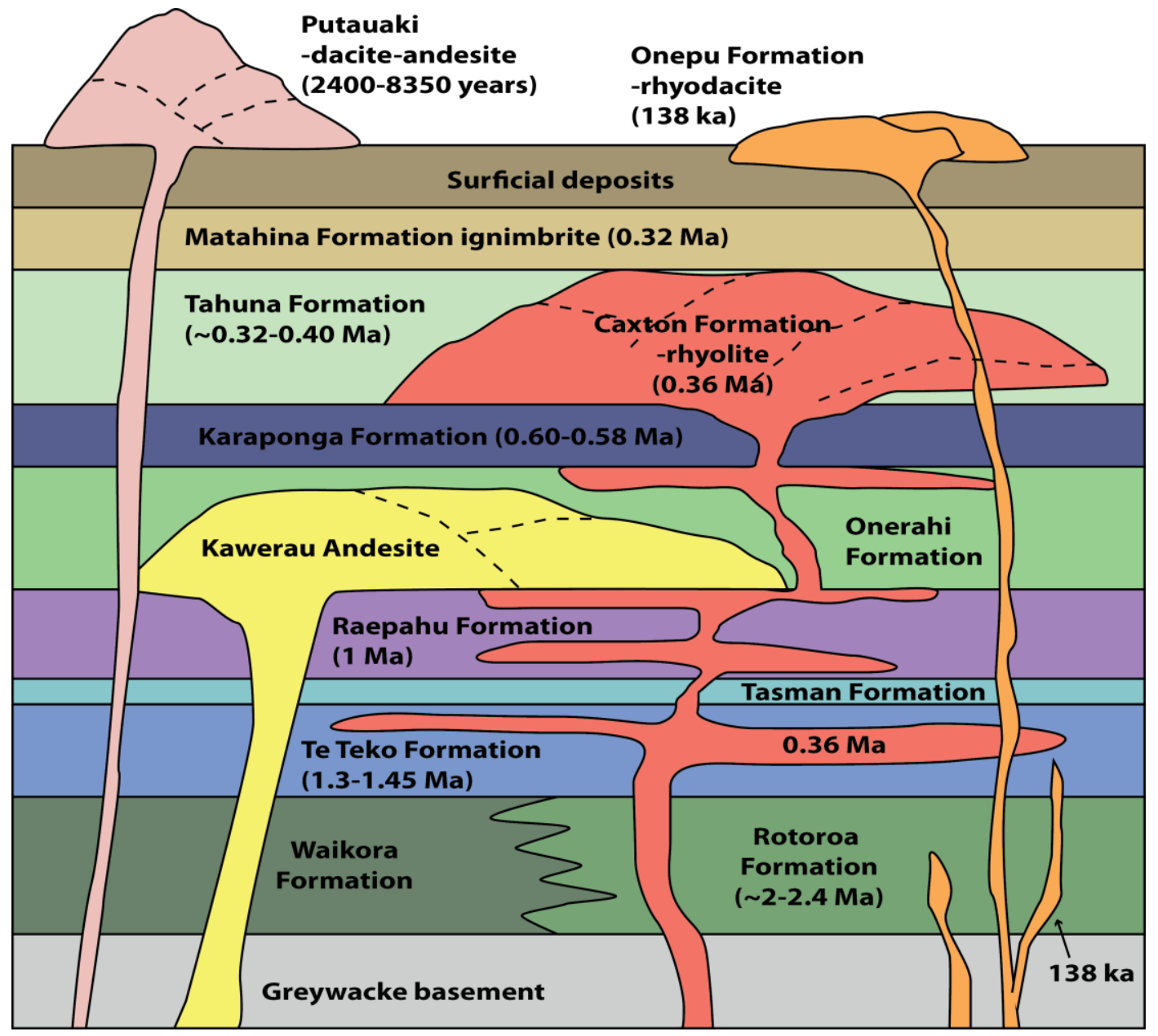

Figure 6.1 Cartoon depiction of the geology in the Kawerau geothermal system with the approximate age of the geological units.

- Deposition of ignimbrite within the Kawerau area was episodic with major units being emplaced at 1.45 - 1.35 Ma (Te Teko Formation), $1.0 \mathrm{Ma}$ (Raepahu Formation), 0.5 0.6 Ma (Karaponga Formation) and 0.32 Ma (Matahina Formation).

- A series of domes and related sill intrusions of the Caxton Formation are identified as being erupted/intruded around $0.36 \mathrm{Ma}$.

- Surficial domes and related dike intrusions of the Onepu Formation are identified as being erupted/intruded around $0.138 \mathrm{Ma}$.

- Tuffs within the Rotoroa Formation above the greywacke basement predate $2 \mathrm{Ma}$ and are likely derived from ignimbrite-forming eruptions in the Coromandel Volcanic Zone, prior to activity in the early TVZ. 
- Northwest-southeast faults (i.e. at a high angle with respect to the modern TVZ structural grain) predate $1.5 \mathrm{Ma}$ and are related to deposition of the Waikora and Rotoroa formation sediments in half-grabens generated by strike-slip faulting.

- Prior to emplacement of the Te Teko Formation (1.46 Ma) there was little remaining topographic relief as this formation is relatively uniform in thickness across the field. The subsequent development of Tasman Formation sediments and palaeosols occurred over about a $0.35 \mathrm{Myr}$ period after the emplacement of the Te Teko Formation ignimbrites, but only in the south-eastern part of the field.

- The Raepahu Formation was deposited at $\sim 1 \mathrm{Ma}$. Its thickness is controlled by faulting structures, mostly in the northwest part of the field, that roughly align to the modern northeast-southwest TVZ grain. The Raepahu Formation is also not a uniform thickness across the field, indicating it has infilled topographic relief created either by faulting or erosion. Following emplacement of the Raepahu Formation ignimbrites, these early northeast-southwest rift related faults became the dominant structural control in the Kawerau area, and probably controlled the position of the Kawerau Andesite feeder zone. The sediments of the 1.0 - 0.6 Ma Onerahi Formation thicken to the northwest, infilling down-faulted structures in this direction. During this time the flows of the Kawerau Andesite were also emplaced.

- By 0.6 Ma (emplacement of the Karaponga Formation), the dominant rifting-related northeast-southwest structures of the TVZ were no longer active. It is possible that this was due to a more general cessation of rifting in the TVZ, as indicated by the general lack of regionally distributed large ignimbrites erupted between 0.71 and $0.35 \mathrm{Ma}$ (Houghton et al., 1995; Leonard et al., 2010). By $\sim 0.4 \mathrm{Ma}$ (emplacement of the Tahuna and Caxton formations) through to the present day, the only known active faults in the area are the Onepu and Rotoitipaku Faults, and the main locus of rifting lies just northwest of the field.

- Accompanying the apparent lack of active rifting, magma generation under the field resulted in emplacement of sills and domes of the Caxton Formation. A lack of active faulting would have resulted in a stress state where the minimum principal stress axis $\left(\sigma_{3}\right)$ was vertically orientated, favouring intrusion of magma as sills, rather than continuous dikes. In the Kawerau area, the change from $\sigma_{3}$ vertical to horizontal and 
orientated northeast-southwest perpendicular to the structural grain of the TVZ (Rowland and Sibson, 2001; Rowland et al., 2010) occurred at some stage after 0.36 Ma and before $0.138 \mathrm{Ma}$ when the dike-fed Onepu Formation domes were erupted. A change from subsidence to uplift of $\sim 3 \mathrm{~mm} / \mathrm{yr}$ average at $\sim 370 \mathrm{ka}$ is inferred from sections on the western shoulder of the modern Whakatane Graben at Matata from ${ }^{40} \mathrm{Ar} /{ }^{39} \mathrm{Ar}$ ages of interbedded tephras (G.S. Leonard et al., unpublished data; Leonard et al., 2009). This change also reflected the onset of uplift of the eastern shoulder of the present-day Whakatane Graben (Mouslopolou et al., 2007, 2008) and development of the present-day highly active rifting regime in this area.

- Cumulative rates of fault movement determined from offsets in the top of units through time show the northeast-southwest faults have accumulated more fault movement over time and that the modern rates can only have been active for $<50,000$ years (based on elevation differences of the top surface of Matahina ignimbrite).

How has the thermal and chemical regime changed in the system and how does this reflect its bydrology and evolution?

The thermal development of the Kawerau geothermal system is summarised in the following discussion and presented in schematic cartoon form in Fig. 6.2. This series of cartoons does not include any of the faulting structure related to the system.

Figure 6.2 This depicts, in schematic cartoons, the development of thermal flux beneath the Kawerau Geothermal Field. The isotherms in each cartoon are approximate and implied only, and are not determined by data or measured well temperatures. The geology key below applies to all the cartoons:

Surficial deposits Putauaki dacite-andesite Onepu Formation Matahina ignimbrite Caxton Formation
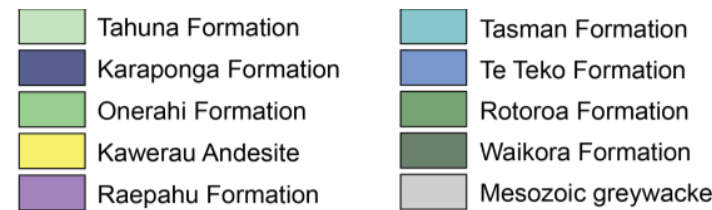

A) Early magmatic intrusion related to the Caxton magmatic system created thermal instability and hydrothermal eruptions at surface $\sim 400 \mathrm{ka}$. (B) Initial growth of the Caxton Formation rhyolite domes and development of a convection plume at $360 \mathrm{ka}$. Hydrothermal features would have been present at surface. (C) Further growth of the Caxton Formation rhyolite domes and emplacement of the Tahuna Formation tuffs and sediments. A welldeveloped hydrothermal system would have been present. (D) Cooling of the magmatic intrusion at depth would have resulted in collapse of the hydrothermal convection plume and hydrothermal activity at surface would have ceased. (E) Early intrusion related to the Putauaki magmatic system created thermal instability and hydrothermal eruptions at surface $\sim 16$ to $9 \mathrm{ka}$. (F) Growth of the Putauaki andesite-dacite dome complex and the development of a hydrothermal convection plume since $\sim 9 \mathrm{ka}$. Hydrothermal features would have been present at surface since that time. This reflects the present day situation in the Kawerau Geothermal Field. 

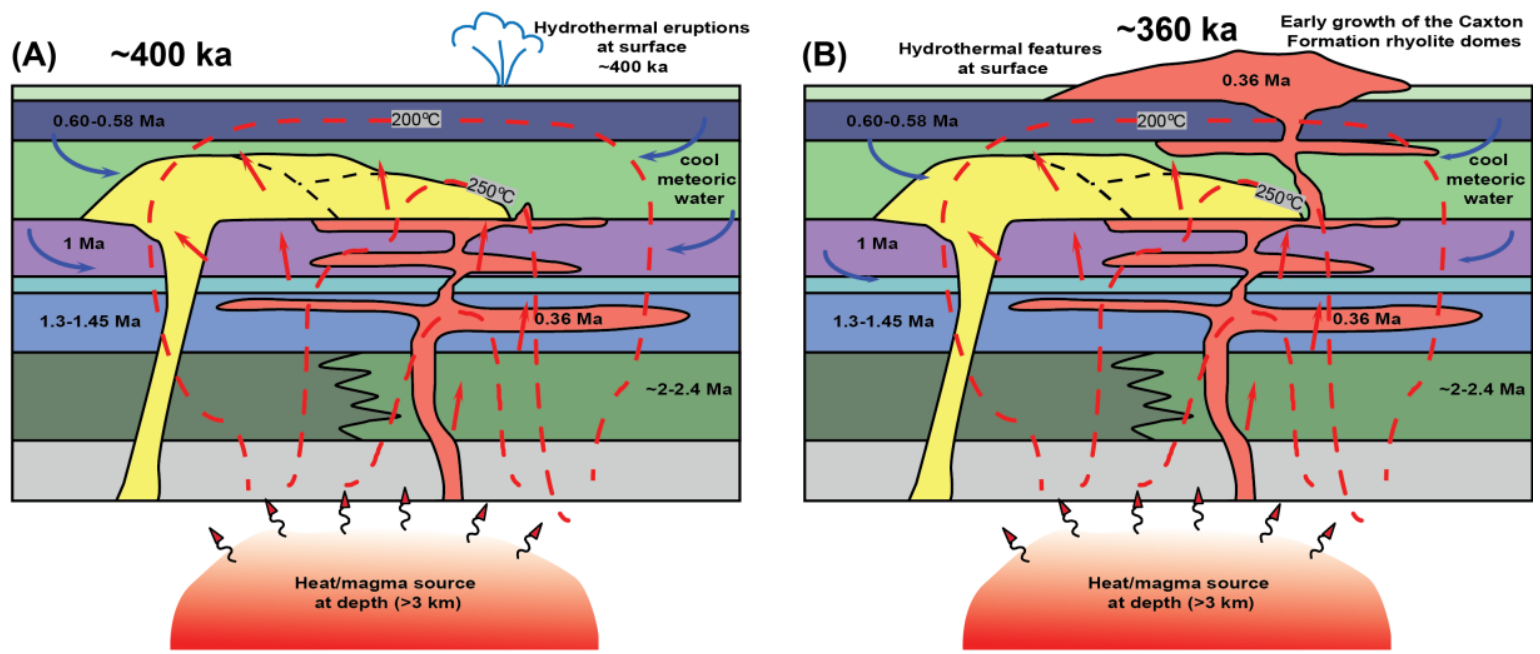

(C) $\sim 360 \mathrm{ka} \quad \begin{gathered}\text { Continued growth of the Caxton Formation } \\ \text { rhyolite domes. Well developed hydrothermal } \\ \text { features at surface }\end{gathered}$
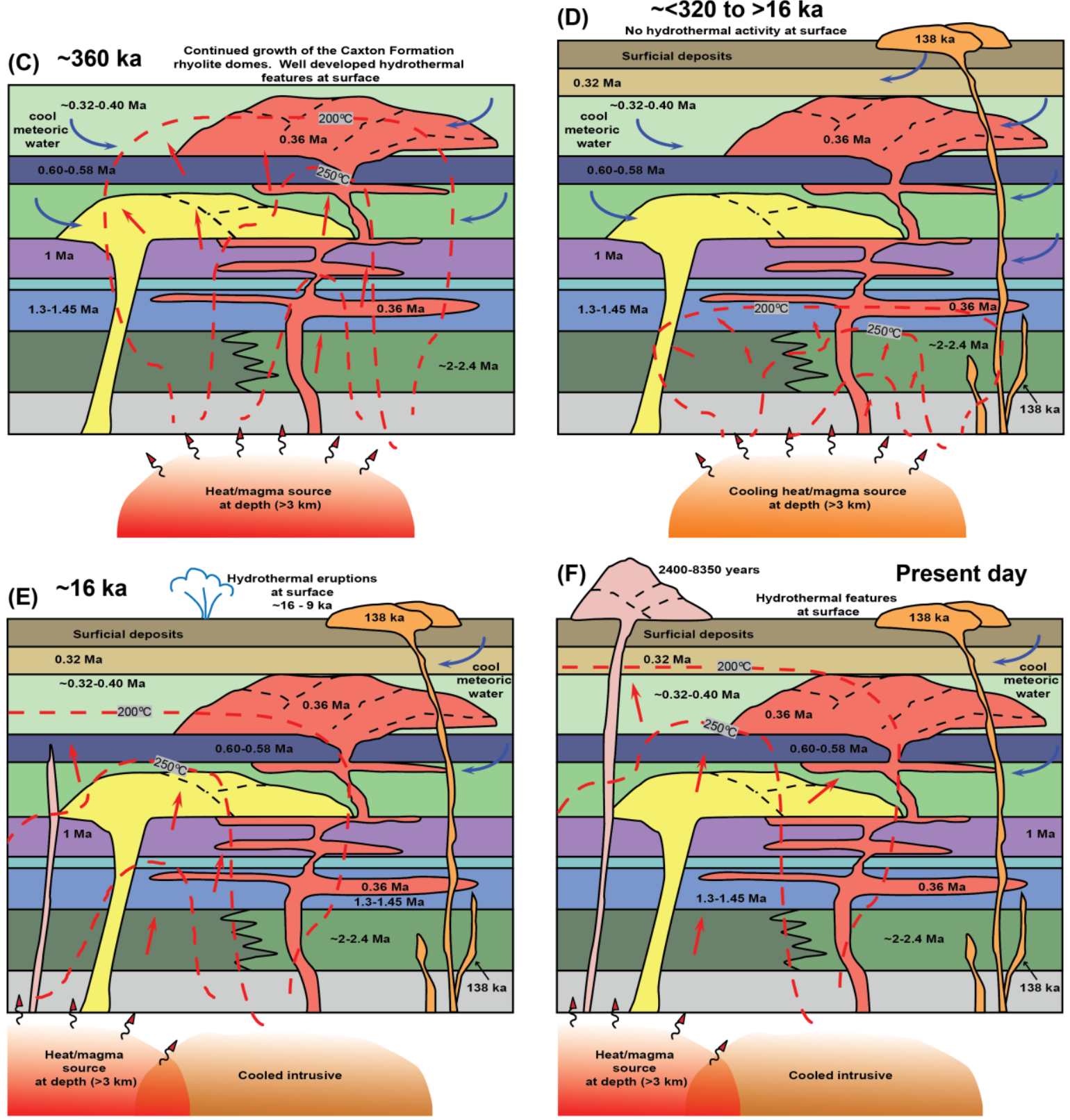
Hydrothermal eruption breccias in eastern parts of the field (of $\sim 16 \mathrm{ka}$ and $\sim 9$ ka age) demonstrate that intense hydrothermal activity was occurring at shallow levels at least at those times. These hydrothermal eruption breccias are linked to intrusion of magma associated with the onset of Putauaki magmatism. The initiation of magmatism beneath the area at this time is also reflected in a generation of hydrothermal calcite and quartz with enriched $\mathrm{O}^{18}$ isotope values, reflecting a pulse of magmatic fluids and $\mathrm{CO}_{2}$ into the system. As meteoric fluid overwhelmed this early isotope signature, both fluid inclusion microthermometry and stable isotope data reflect a change to the present day fluid chemistry (low salinity, meteoricdominated waters).

An earlier period of hydrothermal activity is indicated by a hydrothermal eruption breccia lying stratigraphically beneath the Caxton Formation extrusive domes (Browne, 1979). The heat supply driving the contemporaneous hydrothermal system is inferred to be related to the magmatic system that gave rise to the Caxton Formation rhyolite and the temporally associated Tahuna Formation tuffs. This system would have been initiated around $400 \mathrm{ka}$, then decayed away after $\sim 360 \mathrm{ka}$ when eruptions ceased. The isotopic data attributed to the Caxton magmatic system is also meteoric in origin, indicating that the magma was acting only as a heat source to drive the hydrothermal system, and was not actively contributing magmatic fluids.

This work suggests there have been two geothermal systems in the Kawerau area over the last $\sim 400 \mathrm{kyr}$. The thermal state of the system during the time period between the earlier Caxton and current Putauaki magmatic-driven systems is not known. It is likely though that activity became extinct between these events as the volume of magma represented in the Caxton system ( $\sim 10 \mathrm{~km}^{3}$ maximum) would be able to feed an active geothermal system only for periods of the order of $10^{2}$ to $10^{4}$ years (e.g. Cathles, 1977). 


\subsection{FURTHER QUESTIONS AND FUTURE WORK}

Over the course of addressing the key questions above, many other questions of possible lines of enquiry arose that could be addressed by future work. A selection of these is presented below:

1. What is the age and provenance of the greywacke basement? There is ambiguity in the categorisation of the Kawerau greywacke. Wood et al. (2001) classified the greywacke at Kawerau as belonging to the Waioeka (petro-) facies of the Pahau terrane (i.e., part of the Torlesse composite terrane; Leonard et al., 2010), while Adams et al. (2009) assigned the greywacke to the Waipapa composite terrane. U-Pb dating of detrital zircon obtained from greywacke core collected in drillholes at Kawerau would possibly help to resolve this ambiguity, although the detrital age patterns for the two major composite terranes are closely similar (Adams et al., 2009). An additional benefit would be to help pin the location of the suture between Waipapa and Torlesse composite terranes that occurs in the vicinity of Kawerau. Such information would help resolve whether the major crustal structural weakness resulting from this suture could in fact be a major control on the location of the Kawerau geothermal system itself and on the on-going permeability in the basement of the area.

2. What is the age and provenance of the greywacke sourcing the Waikora Formation greywacke conglomerates? In similar fashion to dating the basement itself, U-Pb dating of detrital zircon from greywacke clasts within the Waikora Formation would give an idea of where the gravels were sourced from (east or west?) and therefore areas undergoing active uplift and erosion at the time of their deposition.

3. What other active faults are present in the Kawerau area? High-quality Light Detection and Ranging (lidar) data have been collected across the Rangitaiki Plains (Begg and Mouslopoulou, 2009), although not processed as far south as the Kawerau area. These data could be processed to see if there are other faults active at Kawerau. The lidar data would permit recognition and description of active fault traces with throws as little as 0.05-0.1 m. It would be interesting to see if there are active faults other than the Onepu fault and Rotoitipaku fault zone in the Kawerau area and how they compare with the faults that have been inputted into the 3-D model (Chapter 4).

4. What are the ages of nearby surficial rhyolite domes? Possible surficial lavas which are age correlatives of the Caxton Formation crop out northwest of Kawerau along the 
northeastern side of Okataina volcano in the Lake Rotoma area. These have been dated only in reconnaissance fashion (Cole et al., 2010) and it would be interesting to see if the rhyolite magmatism represented by the Caxton Formation was more widespread. Likewise, acquiring an age determination for the Puhipuhi dacite, southwest of Kawerau, would be important in linking the magmatic evolution of the Kawerau area with that of the Okataina Volcanic Centre.

5. Can zircon cathodoluminescence (CL) and trace element patterns be used as a correlation tool? On a first pass (“eye-balling"), ignimbrites grouped by age can be fingerprinted by their zircon CL patterns (see Chapter 2). It would be interesting to develop a more robust approach to this, possibly by running CL images of the zircons through imaging software to get a more quantitative light/dark ring ratio.

6. What are the origins and palaeoenvironments of the sediments encountered in the Kawerau drillholes? Only one interval of sediments at Kawerau is definitively marine in origin (indicated by a bivalve fossil: Browne, 1978a). It is unclear whether there may be other intervals of marine sedimentation represented at Kawerau, although distinguishing hydrothermally altered fine-grained marine sediments versus fine-grained lacustrine sediments is problematic. Understanding the origin of the sediments is important, as this would further improve our understanding of the tectonics and palaeotopography of the area. It might be possible to look for marker microfossil assemblages, though organic remains would likely be dissolved by hot geothermal fluids. Another possibility would be to see if X-Ray Diffraction analysis can differentiate clays developed through subaerial soil weathering versus those from marine sediments, or lacustrine/fluvial sediments.

7. Can further investigations provide insight into periods of activity at Kawerau? In hindsight in the use of fluid inclusion microthermometry, looking for evidence of chemical/thermal change from multiple episodes of magmatic heat input, different quartz samples might have been utilised. Most of the samples used for this thesis work were clear quartz, grown into open space. These crystals likely grew late in the system evolution, which would make them inherently unlikely to show evidence of magmatic input. Future work could involve picking 'dirty' vein quartz from close to the vein wall which, while more difficult to find fluid inclusions big enough to analyse, would be earlier in the growth of the vein, and more likely show if there were more saline/hotter fluid inclusion compositions associated with magmatic input. Additionally, using LAICP-MS on individual fluid inclusions after acquiring heating and freezing 
measurements might show differences in trace elements that could be linked to magmatic input. In geothermal environments where the fluid signature is overwhelmed by meteoric water, this may be the only way to discern the influence of magmatic fluids. It would also be beneficial to obtain $\delta \mathrm{D}$ and $\delta^{18} \mathrm{O}$ data from fluid inclusions in hydrothermal minerals which could then be compared directly against the modern reservoir fluids. $\delta \mathrm{D}$ values are less influenced by temperature, and so reflect source fluids better. 
Chapter 6 
CHAPTER 7

\section{REFERENCES}


Absar, A., 1988. Oxygen isotope and hydrothermal alteration studies at Kawerau and OhaakiBroadlands geothermal fields, New Zealand. PhD Thesis, University of Auckland.

Absar, A., Blattner, P., 1985. Successive hydrothermal events as indicated by oxygen isotope composition and petrography of greywacke basement rocks, Kawerau Geothermal Field, New Zealand. Proceedings of the $7^{\text {th }}$ New Zealand Geothermal Workshop, Auckland, New Zealand, 6 - 8 Nov 1985, 115-122.

Absar, A., Blattner, P., 1986. Present-day and extinct geothermal activity at Kawerau- a quantitative approach by oxygen isotopes. In Mongillo, M.A. (Ed.), The Kawerau Geothermal Field: contributions from the 1982 seminar and other recent scientific investigations. Department of Scientific and Industrial Research, Wellington, New Zealand, Geothermal Report 10, 185-190.

Adams, C.J., Mortimer, N., Campbell, H.J., Griffin, W.J., 2009. Age and isotopic characterisation of Torlesse Supergroup and Waipapa Group metasediments in the central North Island, New Zealand. New Zealand Journal of Geology and Geophysics 52, 149-170.

Alcaraz, S.A., Sepulveda, F., Lane, R., Rosenberg, M.D., Rae, A.J., Bignall, G., 2010. A 3-D representation of the Wairakei Geothermal System (New Zealand) using "Earth Research" geothermal visualisation and modelling software. Geothermal Resources Council Transactions 34, 1119-1123.

Alcaraz, S.A., Lane, R., Spragg, K., Milicich, S.D., Sepulveda, F., Bignall, G., 2011. 3-D geological modelling using new Leapfrog Geothermal software. Proceedings of the $36^{\text {th }}$ workshop on Geothermal Reservoir Engineering. Stanford University, USA. pp. 351-356.

Allan, A.S.R., Baker, J.A., Carter, L., Wysoczanski, R.J., 2008. Reconstructing the Quaternary evolution of the world's most active silicic volcanic system: insights from an $\sim 1.65 \mathrm{Ma}$ deep ocean tephra record sourced from Taupo Volcanic Zone, New Zealand. Quaternary Science Reviews 27, 2341-2360.

Allis, R.G., 1997. The natural state and response to development of Kawerau Geothermal Field, New Zealand. Geothermal Resources Council Transactions 21, 3-10.

Allis, R.G., Christenson, B.W., Nairn, I.A., Risk, G.F., White, S.P., 1993. The natural state of Kawerau Geothermal Field. Proceedings of the $15^{\text {th }}$ New Zealand Geothermal Workshop, 227-233. 
Allis, R.G., Christenson, B.W., Nairn, I.A., Risk, G.F., Sheppard, D.S., White, S.P., 1995. Kawerau geothermal field: its natural state and response to development. Client Report 72436C.10, Institute of Geological \& Nuclear Sciences Lower Hutt, New Zealand.

Anonymous, 1904. 37th Annual Report of the Colonial Laboratory. Government Printer, Wellington, New Zealand, pp. 17-18.

Anonymous, 1922. 55th Annual Reportof the Dominion Laboratory. Government Printer, Wellington, New Zealand.

ARANZ Geo Ltd., 2013. http://www.leapfrog3-D.com/products/leapfrog-geothermal.

Arehart, G.B., Christenson, B.W., Wood, C.P., Foland, K.A., Browne, P.R.L., 2002. Timing of volcanic, plutonic and geothermal activity at Ngatamariki, New Zealand. Journal of Volcanology and Geothermal Research 116, 201-214.

Arnorsson, S., 1978. Major element chemistry of the geothermal sea-water at Reykjanes and Svartsengi, Iceland. Mineralogical Magazine 42, 209-220.

Axelsson, G., 2013. Conceptual models of geothermal systems: introduction. Short Course V on Conceptual Modelling of Geothermal Systems. UNU-GTP and LaGeo, Santa Tecla, El Salvador, February 24 - March 2, 2013.

Bailey, R.A., Carr, R.G., 1994. Physical geology and eruptive history of the Matahina Ignimbrite, Taupo Volcanic Zone, North Island, New Zealand. New Zealand Journal of Geology and Geophysics 37, 319-344.

Banwell, C.J., 1962. Development of the Kawerau Geothermal Field, Report for Tasman Pulp and Paper Co., Ltd on Geothermal Survey at Kawerau, pp. 29.

Bardsley, C. 2010. Visualising the geothermal reservoir: Mighty River Power Limited's approach to 3-D geological modelling. GeoNZ 2010 Conference, Auckland, New Zealand: Geoscience Society of New Zealand miscellaneous publication 129A, p.22.

Barth, A.P., Wooden, J.L., 2010. Coupled elemental and isotopic analyses of polygenetic zircons from granitic rocks by ion microprobe, with implications for melt evolution and the sources of granitic magmas. Chemical Geology 277, 149-159. 
Beane, R., Bodnar, R., 1995. Hydrothermal fluids and hydrothermal alteration in porphyry copper deposits. In Pierce, F.W., Bohm J.G. (Eds.), Porphyry Copper Deposits of the American Cordillera. Arizona Geological Society Digest 20, 83-93.

Beanland, S., Melhuish, A., Nicol, A., Ravens, J., 1998. Structure and deformational history of the inner forearc region, Hikurangi subduction margin, New Zealand. New Zealand Journal of Geology and Geophysics 41, 325-342.

Begg, J.G., Mouslopoulou, V., 2010. Analysis of late Holocene faulting within an active rift using lidar, Taupo Rift. New Zealand. Journal of Volcanology and Geothermal Research 190, 152-167.

Berryman, K.R., Beanland, S., 1988. Ongoing deformation of New Zealand: rates of tectonic movement from geological evidence. Transactions of the Institution of Professional Engineers, New Zealand 15, 25-35.

Berryman, K., Beanland, S., Wesnousky, S., 1998. Paleoseismicity of the Rotoitipakau Fault Zone, a complex normal fault in the Taupo Volcanic Zone, New Zealand. New Zealand Journal of Geology and Geophysics 41, 449 - 465.

Bibby, H., 1988. Electrical resistivity mapping in the Central Volcanic Region of New Zealand. New Zealand Journal of Geology and Geophysics 31, 259-274.

Bibby, H.M., Caldwell, T.G., Davey, F.J., Webb, T.H., 1995. Geophysical evidence on the structure of the Taupo Volcanic Zone and its hydrothermal circulation. Journal of Volcanology and Geothermal Research 68, 29-58.

Bignall, G., 2005. Kawerau production well monitoring to July 2005. Institute of Geological \& Nuclear Sciences Client Report 2005/142. 38p.

Bignall, G., 2011. Kawerau Geothermal Field: Geological Assessment. GNS Science Consultancy Report 2010/118. 28p.

Bignall, G., Harvey, C.C., 2005. Geoscientific review of the Kawerau Geothermal Field. Institute of Geological \& Nuclear Sciences Client Report 2005/20. 145p.

Bignall, G., Milicich, S.D., 2012. Kawerau Geothermal Field: geological framework. GNS Science consultancy report, 2012/118. Institute of Geological \& Nuclear Sciences Lower Hutt, New Zealand. 
Bixley, P.F., Clotworthy, A.W., Mannington, W.I., 2009. Evolution of the Wairakei geothermal reservoir during 50 years of production. Geothermics 38, 145-154.

Black, L.P., Kamo, S.L., Allen, C.M., Davis, D.W., Aleinikoff, J.N., Valley, J.W., Mundil, R.M., Campbell, I.H., Korsch, R.J., Williams, I.S., Foudoulis, C., 2004. Improved ${ }^{206} \mathrm{~Pb} /{ }^{238} \mathrm{U}$ microprobe geochronology by the monitoring of a trace-element-related matrix effect: SHRIMP, ID-TIMS, ELA-ICP-MS and oxygen isotope determination for a series of zircon standards. Chemical Geology 205, 115-140.

Blackwood, J.G. and Carter, A.C., 1980. Utilisation of geothermal energy at Tasman Pulp and Paper Company Ltd mill at Kawerau. Appita 33, 363-367.

Blattner, P., 1975. Oxygen isotopic composition of fissure-grown quartz, adularia, and calcite from Broadlands Geothermal Field, New Zealand, with an appendix on quartz-Kfeldspar-calcite-muscovite oxygen isotope geothermometers. American Journal of Science $275,785-800$.

Blattner, P., Woldemichael, S. and Browne, P.R.L., 1994. Stable isotopes as signposts of fluid throughput in Rotokawa and other geothermal fields, and the difficulty of identifying magmatic fingerprints. Proceedings of the $16^{\text {th }}$ New Zealand Geothermal Workshop, 83-84.

Bodnar, R.J., 1993. Revised equation and table for determining the freezing point depression of $\mathrm{H}_{2} \mathrm{O}-\mathrm{NaCl}$ solutions. Geochimica et Cosmochimica Acta, 57, 683-684.

Bodnar, R. J., 1995. Fluid-inclusion evidence for a magmatic source for metals in porphyry copper deposits. Magmas, fluids, and ore deposits: Mineralogical Association of Canada Short Course 23, 139-152.

Bodnar, R.J., 2003. Introduction to fluid inclusions. In Samson, I., Anderson, A., Marshall, D. (Eds.), Fluid Inclusions: Analysis and Interpretation. Mineralogical Association of Canada, Short Course 32, 1-8.

Bogie, I., 1981. The petrography and geochemistry of hydrothermally altered andesite from the Kawerau Geothermal Field. M.Sc. Thesis, University of Auckland, Auckland, New Zealand. 
Booden, M.A., Smith, I.E.M., Mauk, J.L., Black, P.M., 2012. Geochemical and isotopic development of the Coromandel Volcanic Zone, northern New Zealand, since 18 Ma. Journal of Volcanology and Geothermal Research 219-220, 15-32.

Briggs, R.M., Houghton, B.F., McWilliams, M.O., Wilson, C.J.N., 2005. ${ }^{40} \mathrm{Ar} /{ }^{39} \mathrm{Ar}$ ages of silicic volcanic rocks in the Tauranga-Kaimai area, New Zealand: dating the transition between volcanism in the Coromandel Arc and the Taupo Volcanic Zone. New Zealand Journal of Geology and Geophysics 48, 459-469.

Bromley, C.J., 2002. Putauaki (Kawerau) MT resistivity survey. Proceedings of the $24^{\text {th }}$ New Zealand Geothermal Workshop, pp. 135-139.

Bromley, C.J., Hunt, T.M., Morris, C., 1993. Cold downflows of groundwater at Ohaaki Geothermal Field: preliminary results. Proceedings of the $15^{\text {th }}$ New Zealand Geothermal Workshop, Auckland, New Zealand, 181-186.

Brown, P.E., 1998. Fluid inclusion modeling for hydrothermal systems. Reviews in Economic Geology 10, 151-171.

Brown, S.J.A., Wilson, C.J.N., Cole, J.W., Wooden, J., 1998. The Whakamaru group ignimbrites, Taupo Volcanic Zone, New Zealand : evidence for reverse tapping of a zoned silicic magmatic system. Journal of Volcanology and Geothermal Research 84, $1-37$.

Browne, P.R.L., 1970. Hydrothermal alteration as an aid in investigating geothermal fields. Geothermics 2, 564-570.

Browne, P.R.L., 1978a. Petrological logs of drillholes, Kawerau Geothermal Field. New Zealand Geological Survey Report 84, 57 p.

Browne, P.R.L., 1978b. Hydrothermal alteration in active geothermal fields. Annual Review of Earth and Planetary Sciences 6, 229-250.

Browne, P.R.L., 1979. Minimum age of the Kawerau Geothermal Field, North Island, New Zealand. Journal of Volcanology and Geothermal Research 6, 213-215.

Campbell, A.R., Larson, P.B., 1998. Introduction to stable isotope applications in hydrothermal systems. Techniques in hydrothermal ore deposits geology: Reviews in Economic Geology 10, 173-193. 
Carroll, L.D., Gamble, J.A., Houghton, B.F., Thordarson, T. Higham, T.F.G., 1997. A radiocarbon age determination for Mount Edgecumbe (Putauaki) volcano, Bay of Plenty, New Zealand. New Zealand Journal of Geology and Geophysics 40, 559-562.

Carter, L., Shane, P., Alloway, B., Hall, I.R., Harris, S.E., Westgate, J.A., 2003. Demise of one volcanic zone and birth of another - a 12 m.y. marine record of major rhyolitic eruptions from New Zealand. Geology 31, 493-496.

Carter, L., Alloway, B.V., Shane, P., Westgate, J.A., 2004. Deep-ocean record of major late Cenozoic rhyolitic eruptions from New Zealand. New Zealand Journal of Geology and Geophysics 47, 481-500.

Cathles, L., 1977. An analysis of the cooling of intrusives by ground-water convection which includes boiling. Economic Geology 72, 804-826.

Christenson, B.W., 1986. Hydrology and fluid chemistry of the Kawerau geothermal system. In: Mongillo, M.A. (Ed.), The Kawerau geothermal field : contributions from the 1982 seminar and other recent scientific investigations. Department of Scientific and Industrial Research, Geothermal Report 10, 97-145.

Christenson, B.W., 1987. Fluid-mineral equilibria in the Kawerau hydrothermal system, Taupo Volcanic Zone, New Zealand. Ph.D. Thesis, University of Auckland, Auckland, New Zealand.

Christenson, B.W., 1997. Kawerau Geothermal Field: geochemical structure of the reservoir and its response to exploitation. Geothermal Resources Council Transactions 21, 1724.

Clayton, R.N., Steiner, A., 1975. Oxygen isotope studies of the geothermal system at Wairakei, New Zealand. Geochimica et Cosmochimica Acta 39, 1179-1186.

Cole, J.W., 1984. Taupo-Rotorua depression: an ensialic marginal basin of North Island, New Zealand. Geological Society, London, Special Publications 16, 109-120.

Cole, J.W., Darby, D.J., Stern, T.A., 1995. Taupo Volcanic Zone and Central Volcanic Region: backarc structures of North Island, New Zealand. In Taylor, B. (Ed.), Backarc basins: tectonics and magmatism. Plenum Press, New York. p. 1-28. 
Cole, J.W., Spinks, K.D., Deering, C.D., Nairn, I.A., Leonard, G.S., 2010. Volcanic and structural evolution of the Okataina Volcanic Centre; dominantly silicic volcanism associated with the Taupo Rift, New Zealand. Journal of Volcanology and Geothermal Research 190, 123-135.

Coleman, J.L., Shane, P.A.R., Grant-Mackie, J.A., Gregory, M.R., 2001. Identification of a distal ignimbrite in Quaternary strata of the Gisborne area: implications for ignimbrite dispersal, stratigraphy, and paleofauna. New Zealand Journal of Geology and Geophysics 44, 337-345.

Cooper, G.F., Wilson, C.J.N., Millet, M.-A., Baker, J.A., Smith, E.G.C., 2012. Systematic tapping of independent magma chambers during the $1 \mathrm{Ma}$ Kidnappers supereruption. Earth and Planetary Science Letters 313-314, 23-33.

Corfu, F., Hanchar, J.M., Hoskin, P.W.O., Kinny, P., 2003. Atlas of zircon textures. Reviews in Mineralogy and Geochemistry 53, 469-500.

Craig, H., 1961. Isotopic variations in meteoric waters. Science 133, 1702-1703.

Craig, H., 1963. The isotopic geochemistry of water and carbon in geothermal areas. Nuclear geology on geothermal areas, 17-53.

CTECH, 2013. http://www.ctech.com/?page=mvs.

Dalrymple, G.B., Grove, M., Lovera, O.M., Harrison, T.M., Hulen, J.B., Lanphere, M.A., 1999. Age and thermal history of the Geysers plutonic complex (felsite unit), Geysers geothermal field, California: a ${ }^{40} \mathrm{Ar} /{ }^{39} \mathrm{Ar}$ and U-Pb study. Earth and Planetary Science Letters 173, 285-298.

Deering, C.D., Cole, J.W., Vogel, T.A., 2011. Extraction of crystal-poor rhyolite from a hornblende-bearing intermediate mush: a case study of the caldera-forming Matahina eruption, Okataina volcanic complex. Contributions to Mineralogy and Petrology 161, 129-151.

Dempsey, D., Rowland, J., Archer, R., Ellis, S.M., 2011. Modelling geothermal circulation in a "TVZ-like" setting. Proceedings of the $33^{\text {rd }}$ New Zealand Geothermal Workshop, Auckland, New Zealand, 21-23 November 2011. Paper 51. 
Dempsey, D.E., Simmons, S.F., Archer, R.A. and Rowland, J.V., 2012. Delineation of catchment zones of geothermal systems in large-scale rifted settings. Journal of Geophysical Research 117: B10201.

De Ronde, C.E., Blattner, P., 1988. Hydrothermal alteration, stable isotopes, and fluid inclusions of the Golden Cross epithermal gold-silver deposit, Waihi, New Zealand. Economic Geology 83, 895-917.

Diamond, L., 2003. Glossary: Terms and symbols used in fluid inclusion studies. In Samson, I., Anderson, A., Marshall, D. (Eds.), Fluid inclusions: analysis and interpretation. Mineralogical Association of Canada, Short Course 32, 363-372.

Dickinson, D.J., 1973. Aerial infra-red survey of Kawerau, Rotorua and Taupo urban areas 1972. Geophysics Division, Department of Scientific and Industrial Research, Report 89. $53 \mathrm{p}$.

Dickson, M.H., Fanelli, M., 2004. What is geothermal energy? Istituto di Geoscienze e Georisorse, Pisa, Italy. www.geothermal-energy.org/files-31.html.

Downs, D.T., Rowland, J.V., Soengkono, S., Wilson, C.J.N. (2013a). Structural evolution of the central Taupo Volcanic Zone (New Zealand): influences on heat and mass transfer. Tectonophysics (under review).

Downs, D.T., Wilson, C.J.N., Cole, J.W., Rowland, J.V., Calvert, A.T., Leonard, G.S. (2013b). Post-caldera volcano-tectonic interactions in the Taupo Volcanic Zone: rift faulting versus caldera collapse in an ignimbrite eruption. Geological Society of America Bulletin (under review).

Duncan, A.R., 1970. The petrology and petrochemistry of andesite and dacite volcanoes in eastern Bay of Plenty, New Zealand. Ph.D. Thesis, Victoria University of Wellington, Wellington, New Zealand.

Edbrooke, S.W. (compiler), 2005. Geology of the Waikato area: scale 1:250,000. Institute of Geological \& Nuclear Sciences 1:250,000 geological map 4. Institute of Geological \& Nuclear Sciences Limited, Lower Hutt, New Zealand.

Erdman, C.F., Kelsey, H.M., 1992. Pliocene and Pleistocene stratigraphy and tectonics, Ohara Depression and Wakarara Range, North Island, New Zealand. New Zealand Journal of Geology and Geophysics 35, 177-192. 
Faulds, J., Coolbaugh, M., Bouchot, V., Moek, I. and Oguz, K., 2010. Characterizing structural controls of geothermal reservoirs in the Great Basin, USA, and Western Turkey: Developing successful exploration strategies in extended terranes, Proceedings of the World Geothermal Congress 25-30 April 2010, Bali, Indonesia.

Faulds, J.E., Hinz, N.H., Coolbaugh, M.F., Cashman, P.H., Kratt, C., Dering, G., Edwards, J., Mayhew, B. and McLachlan, H., 2011. Assessment of favorable structural settings of geothermal systems in the Great Basin, Western USA. Transactions of the Geothermal Resources Council 35, 777-783.

Field, C., Fifarek, R., 1985. Light stable-isotope systematics in the epithermal environment. Reviews in Economic Geology 2, 99-128.

Finch, R.J., Hanchar, J.M., 2003. Structure and chemistry of zircon and zircon-group minerals. Reviews in Mineralogy and Geochemistry, 53, 1-25.

Fournier, R.O., 1985. The behavior of silica in hydrothermal solutions. In Berger, B.R., Bethke P.M. (Eds.), Geology and Geochemistry of Epithermal Systems, Reviews in Economic Geology 2, 169-202.

Fridleifsson, I.B., Bertani, R., Huenges, E., Lund, J. W., Ragnarsson, A., Rybach, L., 2008. The possible role and contribution of geothermal energy to the mitigation of climate change. In Hohmeyer, O., Trittin, T. (Eds.) IPCC scoping meeting on renewable energy sources, Luebeck, Germany. Proceedings, vol. 20, p. 59-80.

Gifkins, C., Herrmann, W., Large, R.R., 2005. Altered volcanic rocks: A guide to description and interpretation. Centre for Ore Deposit Research, University of Tasmania.

Giggenbach, W.F., 1981. Geothermal mineral equilibria. Geochimica et Cosmochimica Acta $45,393-410$.

Giggenbach, W.F. 1992. Isotopic shifts in waters from geothermal and volcanic systems along convergent plate boundaries and their origin. Earth and Planetary Science Letters 113, 495-510.

GNS Science, 2013. GNS Science Active Fault Database http://www.gns.cri.nz/Home/Products/Databases /Active-Faults-Database-of-NewZealand. 
Goldstein, R.H., 2001. Fluid inclusions in sedimentary and diagenetic systems. Lithos 55, 159193.

Gotze, J., Kempe, U., 2009. Physical principles of cathodoluminescence (CL) and its applications in geosciences. In Gucsik, A. (Ed.), Cathodoluminescence and its application in the planetary sciences. Springer, Berlin, p. 1-22.

Gotze, J., Plotze, M., Habermann, D., 2001. Origin, spectral characteristics and practical applications of the cathodoluminescence (CL) of quartz: a review. Mineralogy and Petrology 71, 225-250.

Graaf, J.H., 2006. The hydrothermal system of Raoul Island: past and present. M.Sc. thesis, University of Auckland, Auckland, New Zealand.

Graham, D.J., Komischke, H., 2005. Thermal features at Kawerau. Institute of Geological \& Nuclear Sciences client report 2005/100. 26p.

Grange, L.I., 1937. The geology of the Rotorua-Taupo subdivision, Rotorua and Kaimanawa divisions. New Zealand Geological Survey Bulletin 37: Government Printer, Wellington, New Zealand, 138p.

Grant, M.A., Bixley, P.F., 2011. Geothermal reservoir engineering. Second edition. Academic Press, Oxford, UK.

Grant, M.A., Southon, J.A.N., 1986. Kawerau Geothermal Field: summary report on investigations and development, New Zealand. Ministry of Works and Development. New Zealand. 19p.

Grant, M.A., Donaldson, L.G., Bixley, P.F., 1982. Geothermal Reservoir Engineering. Academic Press, New York. 369p.

Gravley, D.M., Wilson, C.J.N., Rosenberg, M.D., Leonard, G.S., 2006. The nature and age of Ohakuri Formation and Ohakuri Group rocks in surface exposures and geothermal drillhole sequences in the central Taupo Volcanic Zone, New Zealand. New Zealand Journal of Geology and Geophysics 49, 305-308.

Gravley, D.M., Wilson, C.J.N., Leonard, G.S., Cole, J.W., 2007. Double trouble: Paired ignimbrite eruptions and collateral subsidence in the Taupo Volcanic Zone, New Zealand. Geological Society of America Bulletin 119, 18-30. 
Grindley, G.W., 1965. The geology, structure and exploitation of the Wairakei Geothermal Field, Taupo, New Zealand. New Zealand Geological Survey Bulletin 75.

Grindley, G.W., 1986. Subsurface geology and structure of the Kawerau Geothermal Field. In: Mongillo. M.A. (Ed.), The Kawerau Geothermal Field: contributions from the 1982 seminar and other recent scientific investigations. Department of Scientific and Industrial Research, Wellington, New Zealand, Geothermal Report 10, 49-65.

Grindley, G.W., Browne, P.R.L., 1968. Subsurface geology of the Broadlands Geothermal Field. New Zealand Geological Survey Report 34, 52 p.

Grindley, G.W, Browne, P.R.L., 1976. Structural and hydrological factors controlling the permeabilities of some hot-water geothermal fields. Proceeding of the 2nd United Nations Symposium on Development and Use of Geothermal Resources, p. 377-386.

Guilbert, J.M., Park Jr., C.F., 1986. The geology of ore deposits. Freeman: New York, 985p.

Harlov, D.E., Dunkley, D., 2010. Experimental high-grade alteration of zircon using alkaliand Ca-bearing solutions: resetting the zircon geochronometer during metasomatism. Abstract V41D-2301 presented at 2010 Fall Meeting, AGU, San Francisco, Calif., 1317 Dec.

Healy, J., 1962. Structure and volcanism in the Taupo Volcanic Zone, New Zealand. In: Macdonald, G.A., Kuno, H. (Eds.), The Crust of the Pacific Basin: Geophysical Monograph 6. American Geophysical Union, Washington, D.C., p. 151-157.

Healy, J., 1974. Kawerau Geothermal Field. New Zealand Geological Survey, report 38D.

Healy, J., 1962. Structure and volcanism in the Taupo Volcanic Zone, New Zealand. In: Macdonald, G.A., Kuno, H. (Eds), The Crust of the Pacific Basin: Geophysical Monograph 6. American Geophysical Union, Washington, D.C., pp. 151-157.

Hedenquist, J.W., 1986. Geothermal systems in the Taupo Volcanic Zone: their characteristics and relation to volcanism and mineralisation. Late Cenozoic volcanism in New Zealand: Royal Society of New Zealand Bulletin, 23 134-168.

Hedenquist, J.W., 1990. The thermal and geochemical structure of the Broadlands-Ohaaki geothermal system, New Zealand. Geothermics 19, 151-185. 
Hedenquist, J.W., Browne, P.R.L., 1989. The evolution of the Waiotapu geothermal system, New Zealand, based on the chemical and isotopic composition of its fluids, minerals and rocks. Geochimica et Cosmochimica Acta 53, 2235-2257.

Hedenquist, J.W., Henley, R.W., 1985. The importance of $\mathrm{CO}_{2}$ on freezing point measurements of fluid inclusions: evidence from active geothermal systems and implications for epithermal ore deposition. Economic Geology 80, 1379-1406.

Hedenquist, J.W., Reyes, A.G., Simmons, S.F., Taguchi, S., 1992. The thermal and geochemical structure of geothermal and epithermal systems: a framework for interpreting fluid inclusion data. European Journal of Mineralogy 4, 989-1015.

Henley, R.W., Ellis, A.J., 1983. Geothermal systems ancient and modern: a geochemical review. Earth-Science Reviews 19, 1-50.

Henley, R.W., Truesdell, A.H., Barton, P.B., Whitney, J.A., 1984. Stable isotopes in hydrothermal systems. In Robertson, J.M. (Ed.), Fluid-mineral equilibria in hydrothermal systems. Reviews in Economic Geology Vol. 1. Society of Economic Geologists.

Herbert, A.S., 1921. The hot springs of New Zealand. HK Lewis \& Co Ltd, London.

Hikuroa, D.C.H., Gravley, D.M., Wilson, C.J.N., Browne, P.R.L., Olsen, A.W., 2006. Recent stratigraphic studies at Matata: implications for Kawerau geothermal field modelling and subsurface interpretation. Proceedings of the $28^{\text {th }}$ New Zealand Geothermal Workshop, Auckland, New Zealand, 16-17 November 2006, 6pp (CD-ROM).

Hilton, D.R., 1996. The helium and carbon isotope systematics of a continental geothermal system: results from monitoring studies at Long Valley caldera (California, U.S.A.). Chemical Geology 127, 269-295.

Hochstein, M.P., 1990. Classification and assessment of geothermal resources. In: Dickson, M.H., Fanelli, M. (Eds.), Small Geothermal Resources: A Guide to Development and Utilization, United Nations Institute for Training and Research, New York, 31-57.

Hodgson, K.A., Nairn, I.A., 2004. The sedimentation and drainage history of Haroharo Caldera and the Tarawera River system, Taupo Volcanic Zone, New Zealand. Environment Bay of Plenty Operations Publication 2004/03. 
Hodgson, K.A., Nairn, I.A., 2005. The c.AD 1315 syn-eruption and AD 1904 post-eruption breakout floods from Lake Tarawera, Haroharo caldera, North Island, New Zealand. New Zealand Journal of Geology and Geophysics 48, 491-506.

Holt, R.J., 2007. Numerical Model of the Kawerau Geothermal Reservoir. Report submitted to Mighty River Power Limited, June 18, 2007.

Holt, R., 2013. Statement of evidence of Richard Holt. Application to the Bay of Plenty Regional Council by Mighty River Power Ltd. Presented May 2013, Whakatane, New Zealand.

Hoskin, P.W.O., Schaltegger, U., 2003. The composition of zircon and igneous and metamorphic petrogenesis. Reviews in Mineralogy and Geochemistry 53, 27-62.

Hotson, G.W., 1994. The long term use of geothermal resources at the Tasman Pulp \& Paper Co Ltd's mill, Kawerau, New Zealand. Proceedings of the $16^{\text {th }}$ New Zealand Geothermal Workshop 261-268.

Houghton, B.F., Wilson, C.J.N., McWilliams, M.O., Lanphere, M.A., Weaver, S.D., Briggs, R.M., Pringle, M.S., 1995. Chronology and dynamics of a large silicic magmatic system: central Taupo Volcanic Zone, New Zealand. Geology 23, 13-16.

Jurado-Chichay, Z., Walker, G.P.L., 2000. Stratigraphy and dispersal of the Mangaone Subgroup pyroclastic deposits, Okataina Volcanic Centre, New Zealand. Journal of Volcanology and Geothermal Research 104, 319-383.

Kingston Morrison Ltd. (KML), 1995. A practical guide to applications of science in geothermal systems. Lecture notes presented to various industry partners.

Kissling, W.M., Weir, G.J., 2005. The spatial distribution of the geothermal fields in the Taupo Volcanic Zone, New Zealand. Journal of Volcanology and Geothermal Research 145, 136-150.

Klemm, L.M., Pettke, T., Heinrich, C.A., Campos, E., 2007. Hydrothermal evolution of the El Teniente deposit, Chile: Porphyry $\mathrm{Cu}-\mathrm{Mo}$ ore deposition from low-salinity magmatic fluids. Economic Geology 102, 1021-1045.

Lamarche, G., Barnes, P.M., Bull, J.M., 2006. Faulting and extension rate over the last 20,000 years in the offshore Whakatane Graben, New Zealand continental shelf. Tectonics 25, TC4005, doi:10.1029/2005TC001886. 
Landtwing, M.R., Pettke, T., 2005. Relationships between SEM-cathodoluminescence response and trace-element composition of hydrothermal vein quartz. American Mineralogist 90, 122-131.

Lawless, J., 2002. New Zealand's geothermal resource revisited. New Zealand Geothermal Association Annual Seiminar, Taupo NZ. 14p.

Leonard, G.S., Calvert, A.T., Wilson, C.J.N., Gravley, D.M., Deering, C.D., Hikuroa, D.C.H., 2008. Coastal uplift linked to sea level and a record of early Rotorua-Okataina eruptions: Constraints from new Taupo Volcanic Zone ${ }^{40} \mathrm{Ar}-{ }^{39} \mathrm{Ar}$ geochronology. Abstracts, IAVCEI General Assembly, Reykjavik, Iceland, 17-22 August 2008.

Leonard, G.S., Wilson, C.J.N., Gravley, D.M., Calvert, A.T., Begg, J.G., Rowland, J.V., Hikuroa, D.C.H., 2009. Episodic, shifting volcanism and rifting in central Taupo Volcanic Zone: results from Qmap Rotorua and new geochronology. Geological Society of New Zealand Miscellaneous Publication 128A, p. 121.

Leonard, G.S., Begg, J.G., Wilson, C.J.N. (compilers), 2010. Geology of the Rotorua area: scale 1:250,000. Institute of Geological \& Nuclear Sciences 1:250,000 geological map 5. Institute of Geological \& Nuclear Sciences Limited, Lower Hutt, New Zealand.

Lowe, D.J., Blaauw, M., Hogg, A.G., Newnham, R.M., 2013. Ages of 24 widespread tephras erupted since 30,000 years ago in New Zealand, with re-evaluation of the timing and palaeoclimatic implications of the late-glacial cool episode recorded at Kaipo bog. Quaternary Science Reviews (in press: dx.doi.org/10.1016/j.quascirev.2012.11.022).

Lowenstern, J.B., 2001. Carbon dioxide in magmas and implications for hydrothermal systems. Mineral. Deposita 36, 490-502.

Ludwig, K.R., 2008. Isoplot/Ex version 3.70, a geochronological toolkit for Microsoft Excel. Berkeley, California, Berkeley Geochronology Center Special Publication 4 (revision of August 26, 2008).

Lumb, J.T., 1992. A retrospective study of natural geothermal activity at Kawerau. DSIR Geology and Geophysics Contract Report 1992/44.11p.

Lyon, G.L., Hulston, J.R., 1984. Carbon and hydrogen isotopic compositions of New Zealand geothermal gases. Geochimica et Cosmochimica Acta 48, 1161-1171. 
Macdonald, W.J.P., Muffler, L.J.P., 1972. Recent geophysical exploration of the Kawerau Geothermal Field, North Island, New Zealand. New Zealand Journal of Geology and Geophysics 15, 303-317.

Macdonald, W.J.P., Muffler, L.J.P., Dawson, G.B., 1970. Geophysical investigation at Kawerau. Geophysics Division, Department of Scientific and Industrial Research, Report 62.21p.

MacPherson, E.O., 1944. Notes on the geology of the Whakatane District and Whale Island. New Zealand Journal of Science and Technology 26, 66-76.

Mahon, W.A.J., 1962a. A chemical survey of the steam and water discharged from drillholes and hot springs at Kawerau. New Zealand Journal of Science 5, 417-433.

Mahon, W.A.J., 1962b. A chemical survey of the steam and water discharges from the geothermal sources at Kawerau. Geothermal Circular WAJM13, Department of Industrial and Scientific Research, Wellington, New Zealand.

Manning, D.A., 1996. Middle-late Pleistocene tephrostratigraphy of the eastern Bay of Plenty, New Zealand. Quaternary International 34-36, 3-12.

Manville, V., Newton, E.H., White, J.D.L., 2005. Fluvial responses to volcanism: resedimentation of the 1800a Taupo ignimbrite eruption in the Rangitaiki River catchment, North Island, New Zealand. Geomorphology 65, 49-70.

Manville, V., Hodgson, K.A., Nairn, I.A., 2007. A review of break-out floods from volcanogenic lakes in New Zealand. New Zealand Journal of Geology and Geophysics 50, 131-150.

Martin, R.C., 1961. Stratigraphy and structural outline of the Taupo Volcanic Zone. New Zealand Journal of Geology and Geophysics 4, 449-478.

Massiot, C., Bignall, G., Alcaraz, S.A., Rae, A.J., Sepulveda, F., van Moerkerk, H., 2011. Testing the effectiveness of Leapfrog Geothermal 3-D integrated geological modelling as a geothermal resource exploration and management tool. Transactions of the Geothermal Resources Council 35, 905-909.

McKibbin, R., Absar, A.. Blattner, P., 1986. The transport of oxygen isotopes in hydrothermal systems. Proceedings of the $8^{\text {th }}$ New Zealand Geothermal Workshop, 29-36. 
McNabb, A., 1975. Geothermal physics. Wellington, New Zealand, Department of Scientific and Industrial Research, Applied Mathematics Division, Technical Report 32, 37 p.

Milicich, S.D., 2013a. Petrography of selected samples from the Kawerau Geothermal Field. GNS Science Report, 2013/05.

Milicich, S.D., 2013b. Kawerau Geothermal Field well logs. GNS Science Report, 2013/06.

Milicich, S.D., Fruetsch, F., Ramirez, L.E., Rae, A.J., Alcaraz, S.A., Kallenberg, B., McCoyWest, A.J., Bignall, G., 2010a. Stratigraphic correlation study of the Kawerau Geothermal Field. GNS Science consultancy report 2010/23.

Milicich, S.D., van Dam, M.A., Rosenberg, M.D., Rae, A.J., Bignall, G., 2010b. "Earth Research" 3-dimensional geological modelling of geothermal systems in New Zealand : a new visualisation tool. Proceedings of the World Geothermal Congress 25-30 April 2010, Bali, Indonesia.

Milicich, S.D., Wilson, C.J.N., Bignall, G., Pezaro, B., Charlier, B.L.A., Wooden, J.L., Ireland, T.R., 2013a. U-Pb dating of zircon in hydrothermally altered rocks of the Kawerau Geothermal Field, Taupo Volcanic Zone, New Zealand. Journal of Volcanology and Geothermal Research 253, 97-113.

Milicich, S.D., Wilson, C.J.N., Bignall, G., Pezaro, B., Bardsley, C., 2013b. Reconstructing the geological and structural history of an active geothermal field: a case study from New Zealand. Journal of Volcanology and Geothermal Research 262, 7-24.

Milicich, S.D., Bardsley, C., Bignall, G., Wilson, C.J.N., 2013c. 3-D interpretation of the geology of the Kawerau geothermal system, Taupo Volcanic Zone, New Zealand. Geothermics (in review).

Mock, J.E., Tester, J.W., Wright, P.M., 1997. Geothermal energy from the earth: Its potential impact as an environmentally sustainable resource. Annual review of Energy and the Environment 22, 305-356.

Mongillo, M.A., 1986. The Kawerau Geothermal Field: contributions from the 1982 seminar and other recent scientific investigations. Department of Scientific and Industrial Research. Geothermal Report 10, 97-145.

Mongillo, M.A., 1998. Changes in surface thermal activity at Kawerau Geothermal Field. Institute of Geological \& Nuclear Sciences client report 52891C.10. 
Mongillo, M.A., Bromley, C.J., 1992. Thermal infrared survey of the Kawerau Geothermal Field. Institute of Geological \& Nuclear Sciences client report 1992/103

Mongillo, M.A., Clelland, L., 1984. Concise listing of information on the thermal areas and thermal springs of New Zealand. Department of Scientific and Industrial Research, Wellington, New Zealand. 228p.

Moore, J., Allis, R., Renner, J., Mildenhall, D., McCulloch, J., 2002. Petrologic evidence for boiling to dryness in the Karaha-Telaga Bodas geothermal system, Indonesia. Proceedings of 27th Workshop on Geothermal Reservoir Engineering, Stanford University, USA. SGP-TR-171.

Mortimer, N., 1995. Origin of the Torlesse Terrane and coeval rocks, North Island, New Zealand. International Geology Review 36, 891-910.

Mortimer, N., 2004. New Zealand's geological foundations. Gondwana Research 7, 261-272.

Mouslopoulou, V., Nicol, A., Little, T.A., Walsh, J.J., 2007. Displacement transfer between intersecting regional strike-slip and extensional fault systems. Journal of Structural Geology 29, 100-116.

MRP, 2013. Mighty River Power Ltd. Internal data sets.

Mroczek, E.K., Christenson, B.W., Mountain, B.W., Stewart, M.K., 2001. Kawerau fluid chemistry: analytical results. Institute of Geological \& Nuclear Sciences. Science report 2001/14.

Nairn, I.A., 1977. Geology of Kawerau geothermal field : preliminary report on new data. Geothermal circular IN/1, Department of Industrial and Scientific Research, Wellington, New Zealand.

Nairn, I.A., 1981. Some studies of the geology, volcanic history, and geothermal resources of the Okataina volcanic centre, Taupo Volcanic Zone, New Zealand. Ph.D. thesis, Victoria University, Wellington, New Zealand.

Nairn, I.A., 1982. Geology of Kawerau Geothermal Field (MK11): results of drilling, 19771982, Geothermal circular IAN/4, Department of Industrial and Scientific Research, Wellington, New Zealand. 
Nairn, I.A., 1986. Geology of Kawerau geothermal field - results of drilling, 1977-present. In Mongillo, M.A. (Ed.), The Kawerau Geothermal Field: contributions from the 1982 seminar and other recent scientific investigations. Department of Scientific and Industrial Research, Wellington, New Zealand, Geothermal Report 10, $23-47$.

Nairn, I.A., 1995. The probability and likely effects of a future eruption at Mt Edgecumbe (Putauaki). Institute of Geological \& Nuclear Sciences client report 71415-D.14.

Nairn, I.A., 2002. Geology of the Okataina Volcanic Centre: scale 1:50,000. Institute of Geological \& Nuclear Sciences geological map 25. Institute of Geological \& Nuclear Sciences Limited, Lower Hutt, New Zealand.

Nairn, I.A., Beanland, S., 1989. Geological setting of the 1987 Edgecumbe earthquake, New Zealand. New Zealand Journal of Geology and Geophysics 32, 1-13.

Nairn, I.A., Wiradiradja, S., 1980. Late Quaternary hydrothermal explosion breccias at Kawerau Geothermal Field, New Zealand. Bulletin Volcanologique 43, 1-13.

New Zealand Geothermal Association (NZGA), 2013. New Zealand geothermal fields. New Zealand Geothermal Association. http://www.nzgeothermal.org.nz/nz_geo_fields.html.

Newson, J., O'Sullivan, M., 2001. Modelling of the Ohaaki geothermal system. Proceedings of the $26^{\text {th }}$ Workshop on Geothermal Reservoir Engineering, Stanford, USA. pp. 186192.

Nicol, A., Walsh, J., Berryman, K.R., Villamor, P., 2006. Interdependence of fault displacement rates and paleoearthquakes in an active rift. Geology 34, 865-868.

Norton, D.L., Hulen, J.B., 2001. Preliminary numerical analysis of the magma-hydrothermal history of The Geysers geothermal system, California, USA. Geothermics 30, 211-234.

Norton, D., Knapp, R., 1977. Transport phenomena in hydrothermal systems: the nature of porosity. American Journal of Science 277, 913-936.

Ohmoto, H., 1986. Stable isotope geochemistry of ore deposits. Reviews in Mineralogy and Geochemistry 16, 491-559. 
Ohmoto, H., Rye, R.O., 1979. Isotope of sulfur and carbon. In Barnes, H.L. (Ed.) Geochemistry of hydrothermal ore deposits, $2^{\text {nd }}$ ed., Wiley \& Sons, New York, p. 509567.

O'Neil, J.R., Clayton, R.N., Mayeda, T.K., 1969. Oxygen isotope fractionation in divalent metal carbonates. Journal of Chemical Physics 51, 5547-5558.

Petrucci, E., Sheppard, S.M.F., Turi, B., 1993. Water/rock interaction in the Larderello Geothermal Field (Southern Tuscany, Italy): an ${ }^{18} \mathrm{O} /{ }^{16} \mathrm{O}$ and $\mathrm{D} / \mathrm{H}$ isotope study. Journal of Volcanology and Geothermal Research 59, 145-160.

Pillans, B., Alloway, B., Naish, T., Westgate, J., Abbott, S., Palmer, A., 2005. Silica tephras in Pleistocene shallow-marine sediments of Wanganui Basin, New Zealand. Journal of the Royal Society of New Zealand 35, 43-90.

Pineau, F., Javoy, M., 1983. Carbon isotopes and concentrations in mid-oceanic ridge basalts. Earth and Planetary Science Letters 62, 239-257.

Pollack, H.N., Hurter, S.J., Johnson J.R., 1993. Heat flow from the Earth's interior: Analysis of the global data set. Reviews of Geophysics 31, 267-280.

Price, L., Powell, T.S., Atkinson, L., 2011. Geothermal Fluid Evolution at Rotokawa: Hydrothermal Alteration Indicators. Geothermal Resources Council Transactions 35, 977-982.

Pullar, W.A., 1985. Soils and land use of Rangitaiki Plains, North Island, New Zealand, NZ Soil Bureau, Lower Hutt. NZ Soil Survey Report 86, 75p.

Reed, M.H., Spycher, N., 1984. Calculation of $\mathrm{pH}$ and mineral equilibria in hydrothermal waters with application to geothermometry and studies of boiling and dilution. Geochimica et Cosmochimica Acta 48, 1479-1492.

Reyes, A.G., Christenson, B.W., Faure, K., 2010. Sources of solutes and heat in low-enthalpy mineral waters and their relation to tectonic setting, New Zealand. Journal of Volcanology and Geothermal Research 192, 117-141.

Roedder, E., 1984. Fluid inclusions. Reviews in Mineralogy 12. Mineralogical Society of America. 
Roedder, E., Bodnar, R.J., 1980. Geologic pressure and temperatures from fluid inclusions. Annual Review of Earth and Planetary Sciences 8, 263-301.

Rosenberg, M.D., Bignall, G., Rae, A.J., 2009. The geological framework of the WairakeiTauhara Geothermal System, New Zealand. Geothermics 38, 72-84.

Rowland, J.V., Sibson, R.H., 2001. Extensional fault kinematics within the Taupo Volcanic Zone, New Zealand: soft-linked segmentation of a continental rift system. New Zealand Journal of Geology and Geophysics 44, 271-283.

Rowland, J.V., Sibson, R.H., 2004. Structural controls on hydrothermal flow in a segmented rift system, Taupo Volcanic Zone, New Zealand. Geofluids 4, 259-283.

Rowland, J.V., Simmons, S.F., 2012. Hydrologic, magmatic, and tectonic controls on hydrothermal flow, Taupo Volcanic Zone, New Zealand: implications for the formation of epithermal vein deposits. Economic Geology 107, 427-457.

Rowland, J.V., Wilson, C.J.N., Gravley, D.M., 2010. Spatial and temporal variations in magmaassisted rifting, Taupo Volcanic Zone, New Zealand. Journal of Volcanology and Geothermal Research 190, 89-108.

Rusk, B.G., Lowers, H.A., Reed, M.H., 2008. Trace elements in hydrothermal quartz: Relationships to cathodoluminescent textures and insights into vein formation. Geology 36, 547-550.

Rybach, L., 2007. Geothermal sustainability. Proceedings of the European Geothermal Congress, Unterhaching, Germany, September 2007. p 1-5.

Rye, R.O., Ohmoto, H., 1974. Sulfur and carbon isotopes and ore genesis: a review. Economic Geology 69, 826-842.

Schärer, U., 1984. The effect of initial ${ }^{230} \mathrm{Th}$ disequilibrium on young U-Pb ages: the Makalu case, Himalaya. Earth and Planetary Science Letters 67, 191-204.

Schmitt, A.K., 2011. Uranium series accessory crystal dating of magmatic processes. Annual Review of Earth and Planetary Sciences 39, 321-349. 
Schmitt, A.K., Grove, M., Harrison, T.M., Lovera, O.M., Hulen, J.B., Walters, M., 2003a. The Geysers - Cobb Mountain magma system, California (Part 1): U-Pb zircon ages of volcanic rocks, conditions of zircon crystallization and magma residence times. Geochimica et Cosmochimica Acta 67, 3423-3442.

Schmitt, A.K., Grove, M., Harrison, T.M., Lovera, O.M., Hulen, J.B., Walters, M., 2003b. The Geysers - Cobb Mountain magma system, California (Part 2): timescales of pluton emplacement and implications for its thermal history. Geochimica et Cosmochimica Acta 67, 3443-3458.

Sepulveda, F., Alcaraz, S.A., Lane, R., Rosenberg, M.D., Rae, A.J., Bignall, G., Mannington, W., 2010. 3-D geological model of the Wairakei Geothermal Field. GeoNZ 2010 Conference, Auckland, New Zealand: Geoscience Society of New Zealand miscellaneous publication 129A, p.260.

Shane, P.A.R., 1994. A widespread, early Pleistocene tephra (Potaka tephra, $1 \mathrm{Ma}$ ) in New Zealand: character, distribution, and implications. New Zealand Journal of Geology and Geophysics 37, 25-35.

Sharp, Z. D., 1990. Laser-based microanalytical method for the in situ determination of oxygen isotope ratios of silicates and oxides. Geochimica et Cosmochimica Acta 54, 1353-1357.

Simmons, S.F., Christenson, B.W., 1994. Origins of calcite in a boiling geothermal system. American Journal of Science 294, 361-400.

Simmons, S.F., Browne, P. R. L., Brathwaite, R.L., 1992. Active and extinct hydrothermal systems of the North Island, New Zealand. Society of Economic Geologists, Vol. 15. $121 \mathrm{p}$.

Simon, J.I., Renne, P.R., Mundil, R., 2008. Implications of pre-eruptive magmatic histories of zircons for $\mathrm{U}-\mathrm{Pb}$ geochronology of silicic extrusions. Earth and Planetary Science Letters 266, 182-194.

Simpson, M. P., Mauk, J. L., Bodnar, R., 2010. Geochemistry of fluid inclusions from the Tokatea and Waiorongomai epithermal deposits, Hauraki Goldfield. Proceedings of the 43rd Annual Conference, New Zealand Branch of the AusIMM, 2010, p. 485-496. 
Sinclair Knight Merz (SKM), 2003. Putauaki geothermal project: resource review and exploration well strategy. Report from Sinclair Knight Merz to Mighty River Power Ltd. 71p.

Sorey, M.L., Evans, W.C., Kennedy, B.M., Farrar, C.D., Hainsworth, L.J., Hausback, B., 1998. Carbon dioxide and helium emissions from a reservoir of magmatic gas beneath Mammoth Mountain, California. Journal of Geophysical Research 103, 15303-15323.

Spinks, K., Powell, T., Siega, C. and C., B., 2010. Mighty River Power's resource and development strategy at Kawerau Geothermal Field, New Zealand. Proceedings World Geothermal Congress 2010, Bali, Indonesia.

Stacey, J.S., Kramers, J.D., 1975. Approximation of terrestrial lead isotope evolution by a twostage model. Earth and Planetary Science Letters 26, 207-221.

Stewart, M.K., 1980. Stable isotopes in waters from the Kawerau geothermal area and surroundings. In M.K. Stewart (Ed.), Composition of well discharges at Kawerau. Geothermal Circular MKS-6. DSIR, Institute of Nuclear Sciences. Lower Hutt.

Stimac, J.A., Goff, F., Wohletz, K.H., 2001. Thermal modeling of the Clear Lake magmatichydrothermal system, California, USA. Geothermics 30, 349-390.

Stimac, J.A., Nordquist, G.A., Suminar, A., Sirad-Azwar, L., 2008. An overview of the Awibengkok geothermal system, Indonesia. Geothermics 37, 300-331.

Studt, F.E., 1952. Report on geothermal investigations at Te Teko. Geophysics Division Report No. 4, DSIR, Wellington, 34p.

Studt, F.E., 1958. Geophysical reconnaissance at Kawerau, New Zealand. New Zealand Journal of Geology and Geophysics 1, 219-246.

Taylor Jr., H.P., 1979. Oxygen and hydrogen isotope relationships in hydrothermal mineral deposits. In Barnes, H.J. (Ed.), Geochemistry of hydrothermal ore deposits, $2^{\text {nd }}$ ed., John Wiley, New York, p. 236-277.

Thain, I., Reyes, A.G., Hunt, T., 2006. A practical guide to exploiting low temperature geothermal resources. GNS Science Report 2006/09.

Tian, Y. and Shan, Y., 2011. The diversity of flow structures in felsic dykes. Journal of the Geological Society 168, 1001-1011. 
Truesdell, A.H., Hulston, J.R., 1980. Isotopic evidence on environments of geothermal systems. In Fritz, P., Fontes, J.C. (Eds.), Handbook of environmental isotope geochemistry, Elsevier, Amsterdam, p. 179-226.

Tulloch, A.J., 1990. Petrological logs of drillholes KA 27-35 and KA 10, 17 (deepened), Kawerau Geothermal Field. DSIR Geology and Geophysics contract report 1990/11.

Urey, H.C., 1947. The thermodynamic properties of isotopic substances. Journal of the Chemical Society, 562-581.

Villamor, P., Berryman, K.R., 2001. A Late Quaternary extension rate in the Taupo Volcanic Zone, New Zealand, derived from fault slip data. New Zealand Journal of Geology and Geophysics 44, 243-269.

Villamor, P., Berryman, K.R., 2006. Evolution of the southern termination of the Taupo Rift, New Zealand. New Zealand Journal of Geology and Geophysics 49, 23-37.

Villamor, P., Berryman, K.R., Nairn, I.A., Wilson, K., Litchfield, N., Ries, W., 2011. Associations between volcanic eruptions from Okataina volcanic center and surface rupture of nearby active faults, Taupo rift, New Zealand: Insights into the nature of volcano-tectonic interactions. Geological Society of America Bulletin 123, 1383-1405.

Wallace, L.M., Beavan, R.J., McCaffrey, R., Darby, D.J., 2004. Subduction zone coupling and tectonic block rotations in the North Island, New Zealand. Journal of Geophysical Research 109, B12406.

Werner, C., Cardellini, C., 2006. Comparison of carbon dioxide emissions with fluid upflow, chemistry, and geologic structures at the Rotorua geothermal system, New Zealand. Geothermics 35, 221-238.

White, J.D.L., Houghton, B.F., Hodgson, K.A., Wilson, C.J.N., 1997. Delayed sedimentary response to the A.D. 1886 eruption of Tarawera, New Zealand. Geology 25, 459-462.

White, L.T., Ireland, T.R., 2012. High-uranium matrix effect in zircon and its implications for SHRIMP U-Pb age determinations. Chemical Geology 306-307, 78-91. 
White, N.C., Hedenquist, J.W. 1990. Epithermal environments and styles of mineralisation: variations and their causes, and guidelines for exploration. In Hedenquist, J.W., White, N.C., Siddeley, G. (Eds), Epithermal gold mineralisation of the Circum-Pacific: geology, geochemistry, origin and exploration, II: Journal of Geochemical Exploration $36,445-474$.

White, P., Ussher, G., Hermoso, D., 2010. Evolution of the Ladolam geothermal system on Lihir Island, Papua New Guinea. Proceedings of the World Geothermal Congress, Bali, Indonesia.

Wilkinson, J., 2001. Fluid inclusions in hydrothermal ore deposits. Lithos 55, 229-272.

Wilson, C.J.N., 1986. Reconnaissance stratigraphy and volcanology of ignimbrites from Mangakino volcano. In Smith, I.E.M. (Ed.), Late Cenozoic Volcanism in New Zealand. Royal Society of New Zealand Bulletin 23, 179-193.

Wilson, C.J.N., Charlier, B.L.A., 2009. Rapid rates of magma generation at contemporaneous magma systems, Taupo volcano, New Zealand: insights from U-Th model-age spectra in zircons. Journal of Petrology 50, 875-907.

Wilson, C.J.N., Houghton, B.F., Lloyd, E.F., 1986. Volcanic history and evolution of the Maroa-Taupo area, central North Island. In: I.E.M. Smith (Ed.), Late Cenozoic volcanism in New Zealand. Royal Society of New Zealand Bulletin 23, 194-223.

Wilson, C.J.N., Houghton, B.F., McWilliams, M.O., Lanphere, M.A., Weaver, S.D., Briggs, R.M., 1995a. Volcanic and structural evolution of Taupo Volcanic Zone, New Zealand: a review. Journal of Volcanology and Geothermal Research 68, 1-28.

Wilson, C.J.N., Houghton, B.F., Kamp, P.J.J., McWilliams, M.O., 1995b. An exceptionally widespread ignimbrite with implications for pyroclastic flow emplacement. Nature 378, 605-607.

Wilson, C.J.N., Rhoades, D.A., Lanphere, M.A., Calvert, A.T., Houghton, B.F., Weaver, S.D., Cole, J.W., 2007. A multiple-approach radiometric age estimate for the Rotoiti and Earthquake Flat eruptions, New Zealand, with implications for the MIS 4/3 boundary. Quaternary Science Reviews 26, 1861-1870. 
Wilson, C.J.N., Charlier, B.L.A., Fagan, C.J., Spinks, K.D., Gravley, D.M., Simmons, S.F., Browne, P.R.L., 2008. U-Pb dating of zircon in hydrothermally altered rocks as a correlation tool: application to the Mangakino geothermal field, New Zealand. Journal of Volcanology and Geothermal Research 176, 191-198.

Wilson, C.J.N., Gravley, D.M., Leonard, G.S., Rowland, J.R., 2009. Volcanism in the central Taupo Volcanic Zone, New Zealand: tempo, styles and controls. In Thordarson, T., Self, S., Larsen, G., Rowland, S.K., Hoskuldsson, A. (Eds.), Studies in volcanology: The legacy of George Walker. Geological Society, London, pp. 225-247.

Wilson, C.J.N., Charlier, B.L.A., Rowland, J.V., Browne, P.R.L., 2010. U-Pb dating of zircon in subsurface, hydrothermally altered pyroclastic deposits and implications for subsidence in a magmatically active rift: Taupo Volcanic Zone, New Zealand. Journal of Volcanology and Geothermal Research 191, 69-78.

Wood, C.P., Brathwaite, R.L., Rosenberg, M.D., 2001. Basement structure, lithology and permeability at Kawerau and Ohaaki geothermal fields, New Zealand. Geothermics 30, $461-481$.

Wright, I.C., 1992. Shallow structure and active tectonism of an offshore continental back-arc spreading system: the Taupo Volcanic Zone, New Zealand. Marine Geology 103, 287 309.

Yoshikawa, T., 1993. Geomorphic development of axial ranges in eastern North Island, New Zealand, correlated with ignimbrite volcanism in the Taupo Volcanic Zone. Bulletin of the Department of Geography, University of Tokyo 25, 1-27.

Zheng, Y.F., 1990. Carbon-oxygen isotopic covariation in hydrothermal calcite during degassing of $\mathrm{CO}_{2}$. Mineralium Deposita 25. 246-250.

Zheng, Y.F., 1993. Calculation of oxygen isotope fractionation in anhydrous silicate minerals. Geochimica et Cosmochimica Acta 57, 1079-1091. 
Chapter 7 
APPENDIX A

GRAPHICAL WELL LOGS 
The graphical logs in this appendix were published as an electronic supplement for Milicich et al. (2013b) [Chapter 3]. Ages on the logs are from Milicich et al. (2013a) [Chapter 2]. The map in Figure A1 includes well numbers to aid with interpretation of the logs.

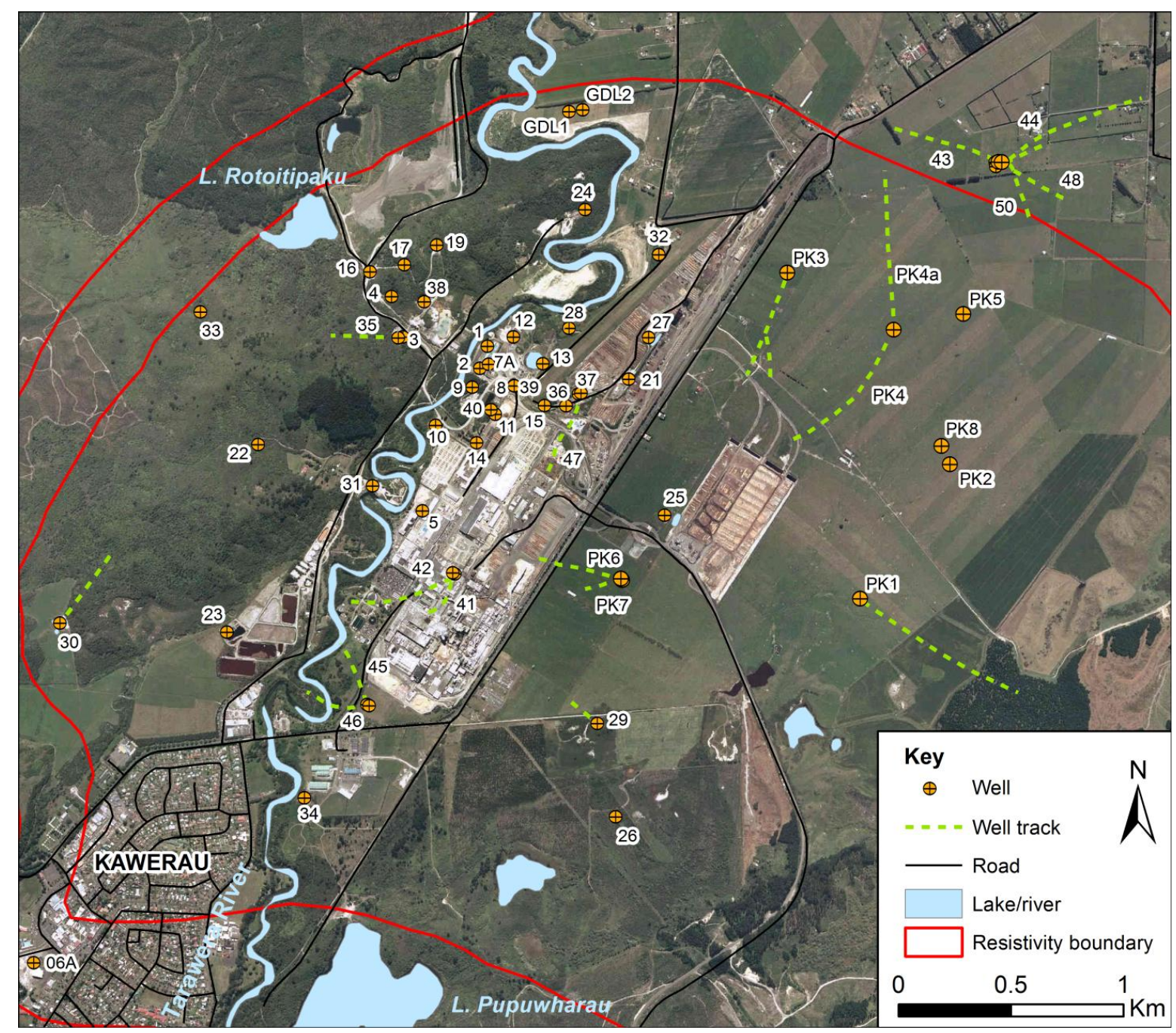

Figure A1

Map of Kawerau Geothermal Field showing drillholes, active faults (GNS Science, 2013), and approximate resistivity boundary zone defined at about $500 \mathrm{~m}$ depth (after Allis, 1997). Wells with no prefix belong to the ' $\mathrm{KA}$ ' series of wells. 


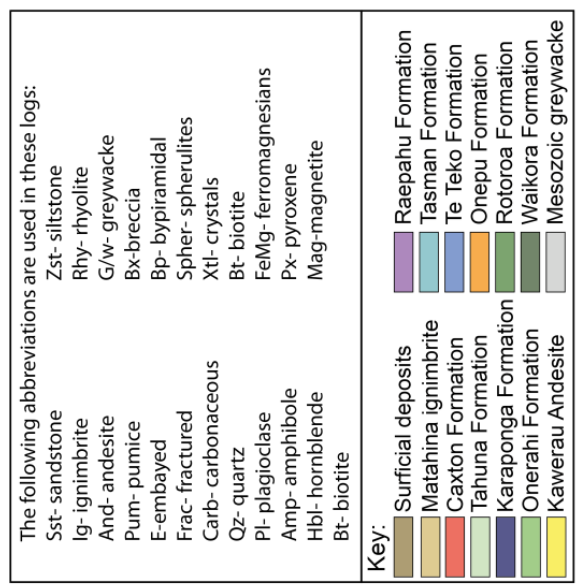

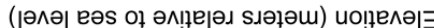

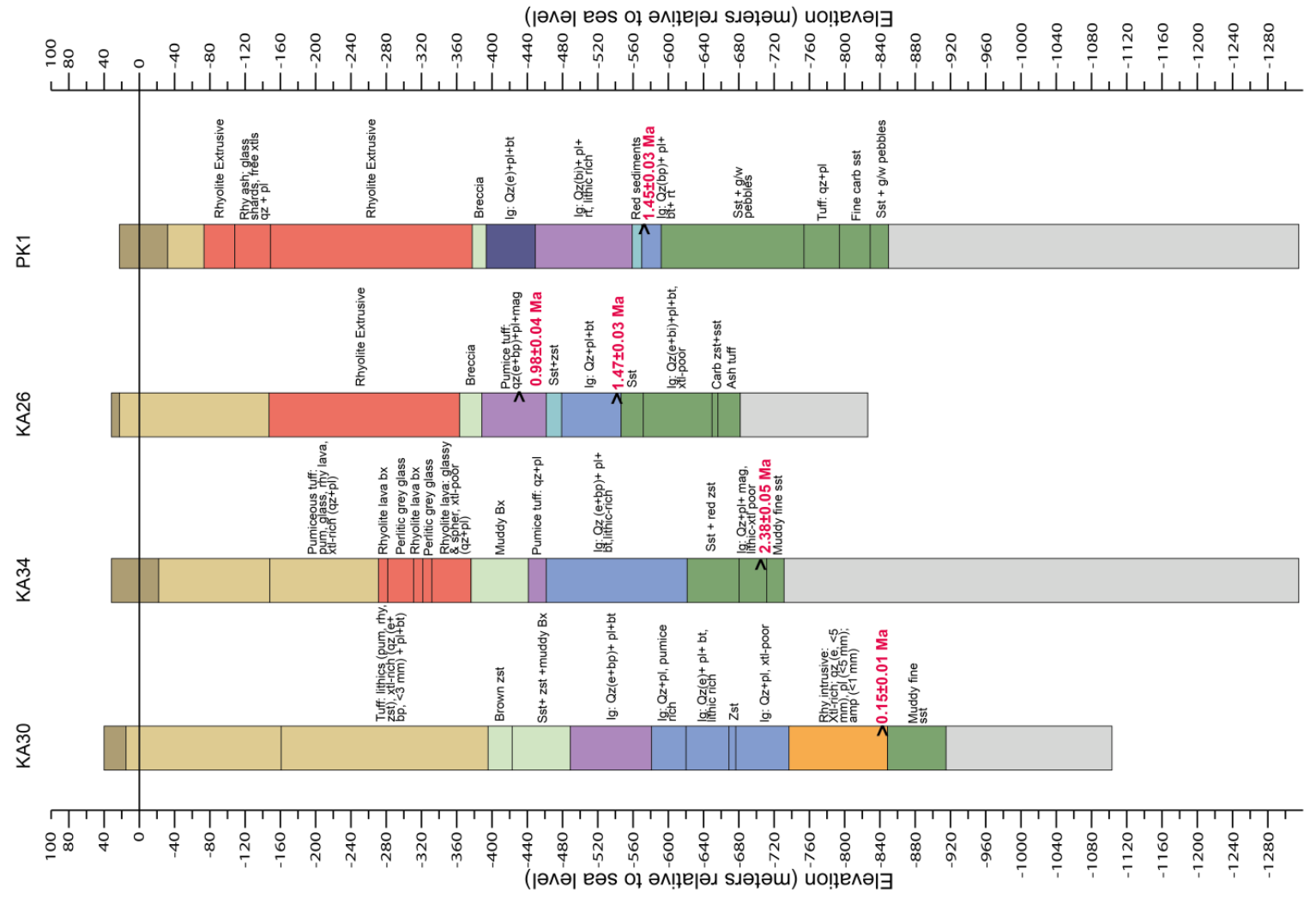




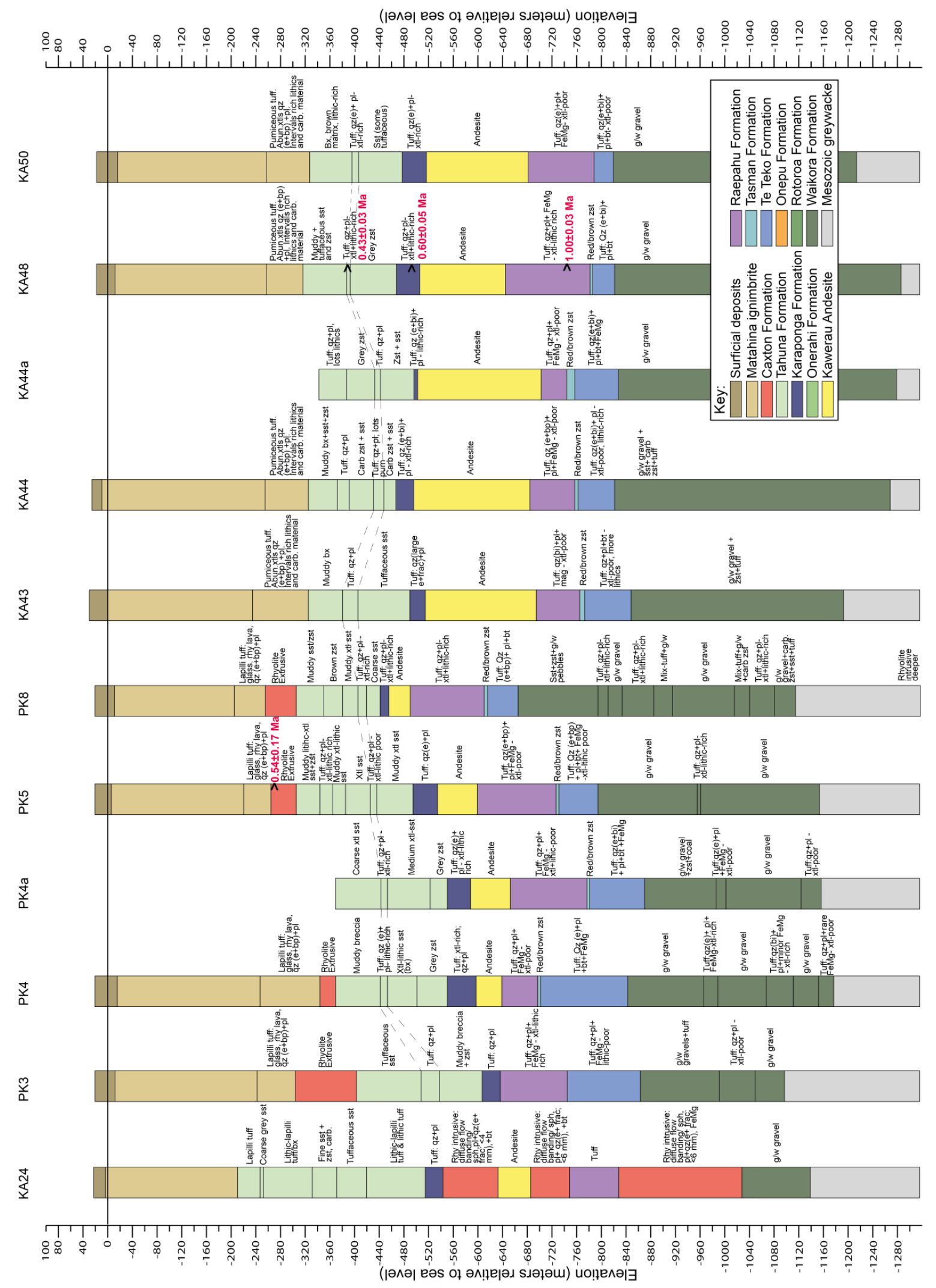




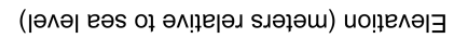

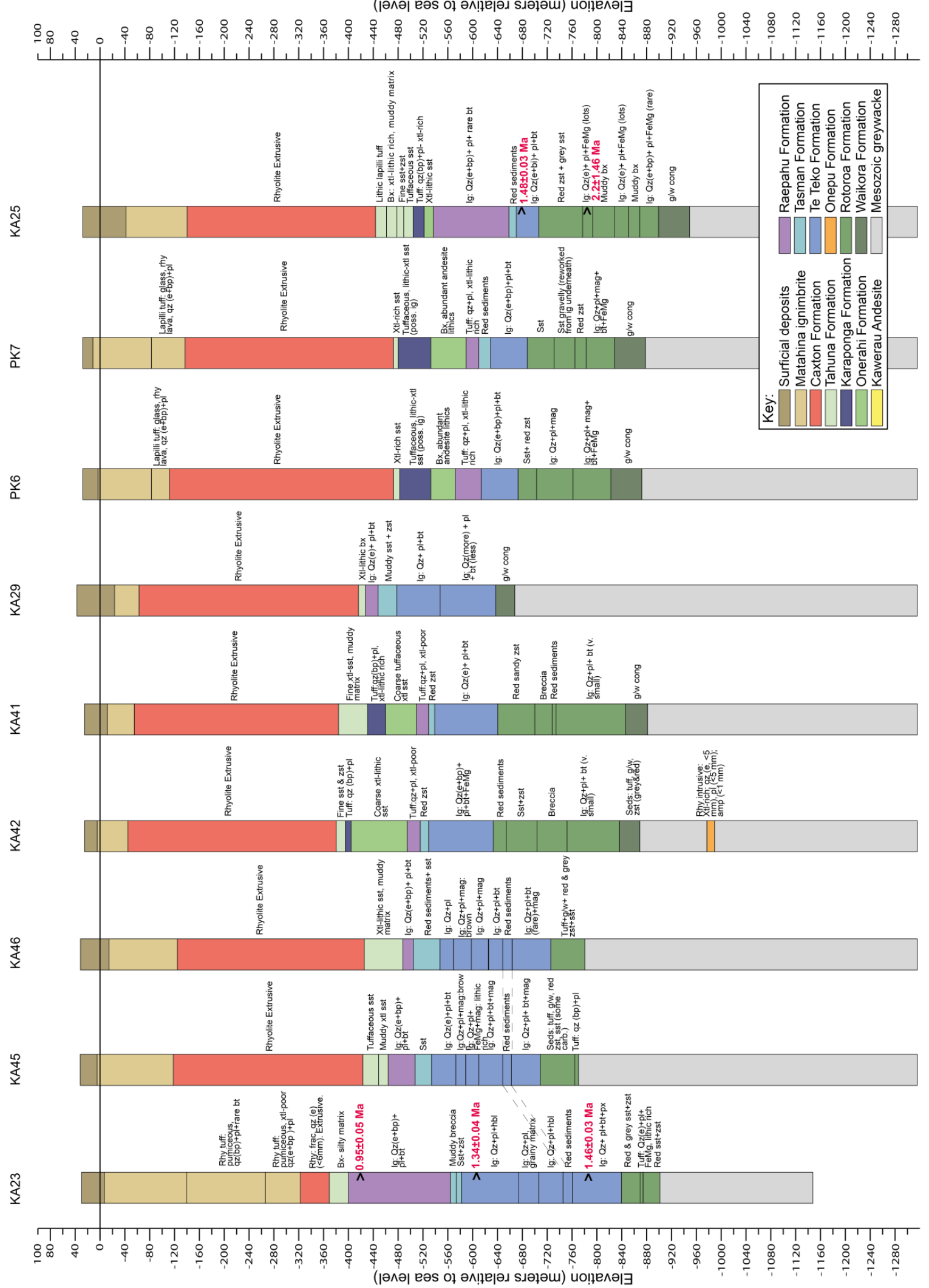

